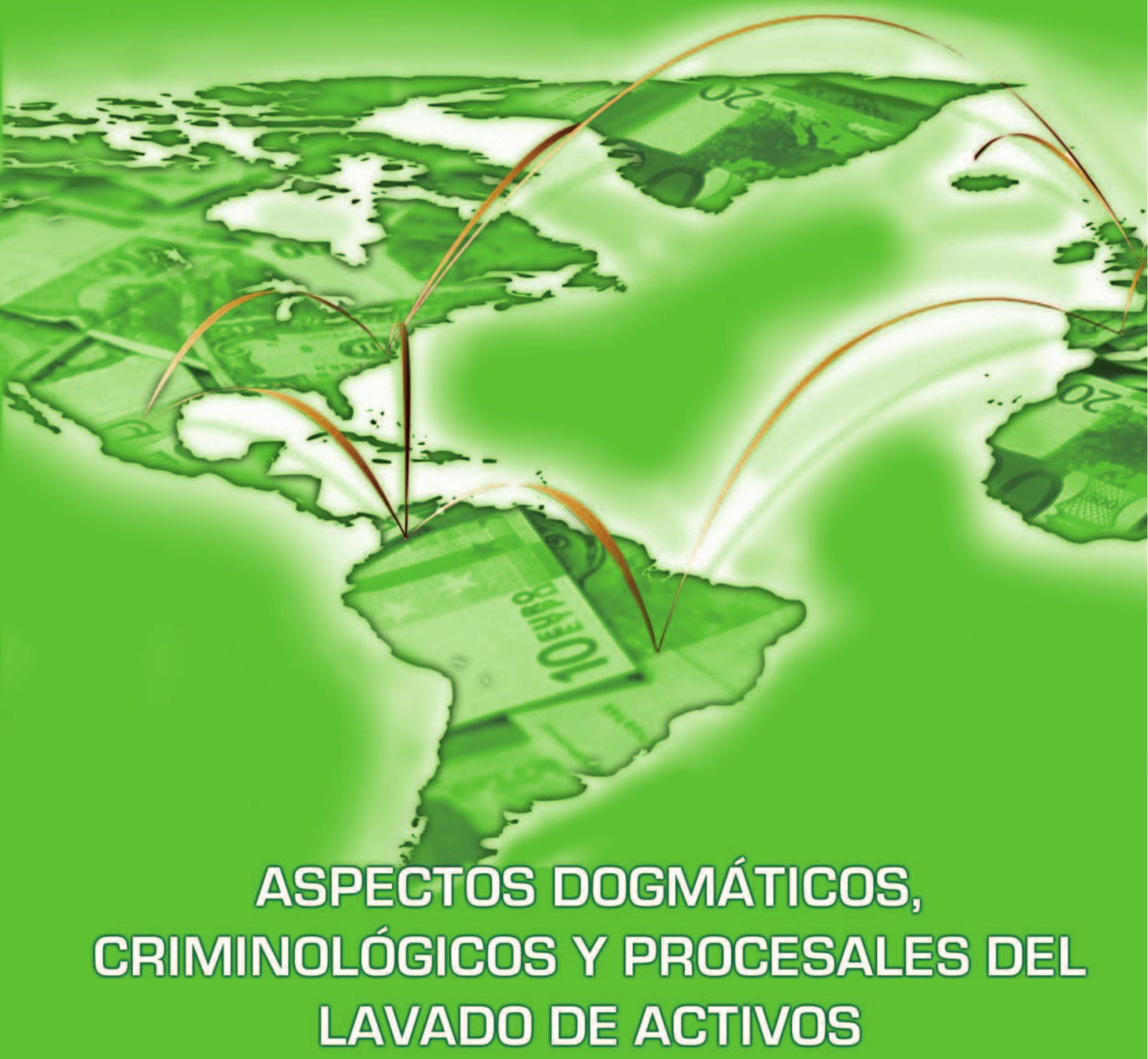

Justicia y

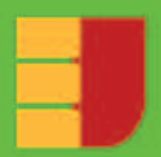




Aspectos Dogmáticos, Criminológicos y Procesales del Lavado de Activos

\section{Principales Contribuyentes:}

Norma Bautista

Heiromy Castro Milanés

Olivo Rodríguez Huertas

Alejandro Moscoso Segarra

Maximiliano Rusconi

\section{Edición:}

Proyecto Justicia y Gobernabilidad

Ave. Pedro Henriquez Ureña No. 133

Edif. Empresarial Reyna I

Santo Domingo Republica Dominicana

Esta publicación ha sido desarrollada con fondos de la Agencia de los Estados Unidos para el Desarrollo Internacional (USAID). Las opiniones expresadas en la misma pertenecen a los contribuyentes y no necesariamente reflejan el punto de vista ni las opiniones de USAID.

Justicia y

Gobernabilidad

$\overline{\text { Fortaleciendo el estado de derecho }}$

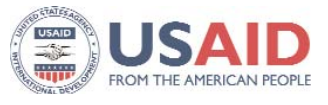

1 ra. edición, 2005

1,000 ejemplares

Corrección de estilo:

Bridges. Leading Conversations

info@bridges-Ic.com

Diseño de portada, diagramación y arte final:

Bridges. Leading Conversations

info@bridges-Ic.com

Impresión:

Mediabyte, S.A. 


\section{ASPECTOS DOGMÁTICOS, CRIMINOLÓGICOS Y PROCESALES DEL LAVADO DE ACTIVOS}





\section{ASPECTOS DOGMÁTICOS, CRIMINOLÓGICOS Y PROCESALES DEL LAVADO DE ACTIVOS}

NORMA BAUTISTA

HEIROMY CASTRO MILANÉS

OLIVO RODRÍGUEZ HUERTAS

ALEJANDRO MOSCOSO SEGARRA

MAXIMILIANO RUSCONI

Justicia y

Gobernabilidad

Fortaleciendo el estado de derecho 



\section{PRÓLOGO \\ Dr. Jorge A. Subero Isa \\ Presidente de la Suprema Corte de Justicia de la República Dominicana}

El crimen organizado ha existido desde que existen las leyes, siempre ha habido personas y grupos quienes quebrantando el ordenamiento jurídico, social y moral de las sociedades han tratado de sacar provecho de lo prohibido en cierto momento y lugar de la historia. Sin importar el país ni su nivel de desarrollo, el dinero obtenido de estos actos ilícitos era insertado a la economía legal. Con la globalización de los mercados estas organizaciones tienen una mayor gama de opciones para intentar invertir y limpiar así sus ganancias. Las estadísticas sobre el lavado de dinero son asombrosas, y nos damos cuenta de la incidencia que tiene este delito cuando el Fondo Monetario Internacional (FMI) estima que el monto que se lava en un año a nivel mundial representa del $2 \%$ al $5 \%$ del $\mathrm{PBI}$, mientras que para América Latina una estimación bruta parece ubicarlo entre el $2,5 \%$ y $6,3 \%$ del PIB regional anual.

Hoy en día, con los avances jurídicos, tecnológicos y democráticos hemos logrado que esta inserción de capitales a las economías mundiales sea cada vez más difícil. Puesto que, aunque el nivel de tolerancia mundial hacia el Lavado de Activos siempre ha sido bajo, han existido países que no cooperan con la lucha contra este delito. Sin embargo, podemos afirmar que el índice ha disminuido habiendo hoy muy pocos países y territorios que no cooperan con los organismos internacionales. Pero esto no significa que la labor que tienen los países se ha simplificado, muy por el contrario, mientras mayor seguridad existe en los mercados más complicado y difícil de detectar se torna el blanqueo de capitales.

El lavado de activos es un tema de gran interés para economías en desarrollo como la nuestra, donde las reglas aunque claras, son relativamente nuevas lo que permite a los que practican esta actividad nutrirse de los huecos del sistema para poder invertir dinero fruto del narcotráfico u otras actividades ilícitas en actividades lícitas para así "blanquear" sus activos. 
Al mismo tiempo tenemos una economía mayormente de servicios, por lo que también estamos expuestos a ser utilizados para el lavado de capitales. La fuente principal de divisas de la República Dominicana es el dólar generado por el turismo, las zonas francas y las remesas de los dominicanos residentes en el exterior. Por medio de estas actividades y muchas otras de naturaleza comercial, capital generado por actividades ilícitas entran a nuestro país. Para estos propósitos se utilizan servicios electrónicos bancarios y no bancarios ofrecidos de manera legítima por instituciones nacionales e internacionales, las cuales ofrecen circunstancias ideales para el lavado de activos.

Es por ello que en nuestro país es de suma importancia la capacitación en esta área, no sólo para los jueces que deben estar preparados para afrontar este delito en los tribunales, sino también abogados, banqueros, corredores inmobiliarios, entre otros, deberían tener conocimientos específicos orientados a sus funciones, con miras a prevenir la ejecución de dicho crimen.

Desde hace algunos años nuestro país posee normativas legales que sancionan, tipifican, y hasta tratan de controlar el lavado de activos, sin embargo como signatario de múltiples convenciones, tratados y declaraciones internacionales contra el Lavado de Capitales se encontró con la necesidad de crear un marco legal que se ajuste a los lineamientos internacionales a los que se ha comprometido con la finalidad de controlar y combatir dicho delito. Con estos fines en mente fue que se promulgó en el 2002 la "Ley contra el lavado de activos provenientes del tráfico ilícito de drogas y sustancias controladas y otras infracciones graves". Con esta promulgación nuestro país continúa con mayor fuerza la lucha contra uno de los males que corroe nuestra sociedad.

Es por esto que un grupo de expertos a solicitud de la Escuela Nacional de la Judicatura y con el financiamiento de la USAID, a través de su programa Justicia y Gobernabilidad/DPK han aunado esfuerzos para crear este libro que tienen hoy en sus manos, el cual al mismo tiempo se utilizará como bibliografía exigida para el Curso Virtual de Lavado de Activos que ofertará la Escuela Nacional de la Judicatura en el año 2005. En espera de que esta iniciativa, que busca capacitar a distancia a la mayor cantidad de profesionales, empezando con los jueces, aumente la demanda de información sobre el tema e incentive a más juristas criollos a escribir e investigar sobre el tema, para lograr así que los profesionales dominicanos tengan opciones de capacitación sobre el tema. 




\section{INDICE GENERAL}

\section{MODULO I:}

LAVADO DE ACTIVOS. GENERALIDADES

Olivo Rodriguez. Huertas

Objetivo específico:

Proveer de herramientas actualizadas para el tratamiento eficiente en el sistema judicial del lavado de activos.

Contenido:

1. El problema criminológico del lavado de activos

1.1 El punto de partida de la preocupación internacional

2. Concepto: ¿Qué es el lavado de activos?

2.1 Distintas denominaciones utilizadas

3. Etapas del lavado de activos: Métodos comunes
3. 1 Colocación
3.2 Estratificación o intercalación
3.3 Integración o inversión

4. Características del lavado de activos
4. 1 Naturaleza internacional
$4.2 \quad$ Volumen del fenómeno
4.3 Profesionalización
4.4 Variedad y variación de las técnicas empleadas
4.5 Otras características

5. Factores que han favorecido su desarrollo
5.1 Globalización económica mundial
5.2 Liberalización de los movimientos de capital y desregulación bancaria
5.3 Revolución tecnológica
5.4 Paraísos fiscales y secreto bancario
5.5 El desarrollo de modelos de criminalidad organizada 
6. Línea de acción
6. 1 Penalización del lavado de activos
6.2 Incautación y decomiso de bienes
6.3 Asistencia judicial internacional
6.4 Desarrollo de modelos de investigación penal para casos complejos
6.5 Régimen de prevención y sanciones administrativas
6.6 Establecimiento de mecanismos de evaluación multilateral

\section{MÓDULO II:}

Olivo Rodriguez. Huertas

Objetivo específico:

Facilitar el acceso a la normativa internacional en materia de lavado de activos, así como el conocimiento de su contenido y el alcance de su fuerza vinculante.

Contenido:

1. Introducción

2. El impacto normativo interno de la legislación internacional
2.1 Jerarquía normativa de los compromisos internacionales asumidos: dualismo y monismo
2.2 Tratamiento jurisprudencial en República Dominicana sobre la jerarquía interna de los Tratados Internacionales

3. Principales órganos internacionales y grupos de trabajo sobre lavado de activos

4. Diversidad de instrumentos internacionales

5. Tratados Internacionales
5. 1 Tratados de alcance universal:
5.2 Tratados regionales en el ámbito europeo
5.3 Tratados regionales en el ámbito americano

6. Declaraciones y Recomendaciones de alcance universal
6.1 Declaraciones y Recomendaciones de alcance universal
6.2 Declaraciones y Recomendaciones en el ámbito europeo
6.3 Declaraciones y Recomendaciones en el ámbito americano

7. Propuestas Normativas
7. $1 \quad$ Modelo de Ley PNUFID
7.2 Reglamento Modelo OEA-CICAD 


\section{MÓDULO III:}

\section{EL LAVADO DE ACTIVOS EN LA LEGISLACIÓN DOMINICANA}

\section{Alejandro Moscoso Segarra}

Objetivo específico:

Ofrecer las herramientas para un manejo adecuado de la legislación nacional en materia de definición del lavado de activos y otras infracciones jurídico-penales vinculadas al mismo.

Contenido:

1. Introducción. La complejidad del tipo penal del lavado de activos.

2. Origen y evolución de la tipificación del lavado de activos en la República ominicana
$2.1 \quad$ Ley 50-88 del 30 de mayo de 1988
2.2 La ley 17-95 del 17 de diciembre de 1996
2.3 Ley 72-02 del 29 de mayo de 2002

3. El sistema normativo de la ley $\mathbf{7 2 - 0 2}$

4. La conducta típica del lavado de activos en la ley 72-02

4.1 Elementos del tipo objetivo del lavado de activos

5. Elementos del tipo subjetivo del lavado de activos

6. El dolo: conocimiento y la voluntad de realizar el tipo objetivo

7. Tipo subjetivo y error de tipo. Problemas particulares.

8. Situaciones que agravan la punibilidad: el artículo 21 de la Ley 72-02

MODULO IV:

PROBLEMAS ESPECIALES DE PARTE GENERAL EN LA INTERPRETACIÓN DEL LAVADO

DE ACTIVOS

Maximiliano Rusconi

Objetivo específico:

Profundizar en el desarrollo de las cuestiones de la parte general del derecho penal que adquieren especial relevancia en la aplicación de la legislación vinculada con el lavado de activos, procurando mejorar los niveles de conocimiento dogmático en el sistema de administración de justicia.

Contenido:

1. Algunas consideraciones específicas con relación a los tipos penales del lavado de activos

2. Cuestiones dogmáticas específicas del ilícito de lavado de activos en la Ley 72-02 
2.1 Problemas a resaltar en la redacción del artículo 3 de la ley 72-02

2.2 El incremento patrimonial no justificado y el artículo 4 de la Ley 72-02

3. Autoría y participación en lavado de capitales

3. 1 La definición del autor. El modelo legislativo

3.2 El autor mediato en la dogmática penal y el autor mediato en la ley 72-02

3.3 La coautoría en el ámbito del delito de lavado de dinero

4. Los problemas concursales

4.1 Las reglas concursales y el lavado de capitales

4.2 La relación con el delito base

4.3 La construcción del dolo a partir de las circunstancias del hecho: nuevamente el artículo 4 de la ley $72-02$

5. La tentativa del lavado de activos. La estructura del delito tentado y su manifestación en el sistema represivo del lavado de activos

5.1 Principio de ejecución: actos preparatorios y actos ejecutivos

5.2 La tentativa en delitos calificados, habituales y en la autoría mediata

5.3 Tentativa inidónea, delito imaginario (o putativo) y ausencia de tipo

6. El desistimiento voluntario en el marco del delito tentado

7. La tentativa en los delitos de estructura omisiva

8. Responsabilidad por omisión en posición de garante

\section{MODULO V:}

\section{ASPECTOS PROCESALES EN EL ENJUICIAMIENTO PENAL DEL LAVADO} DE ACTIVOS

Norma Bautista, Heiromy Castro Milanés, Alejandro Moscoso Segarra y Olivo Rodríguez. Huertas

Objetivo específico:

Identificar mecanismos procesales a efectos de aumentar los niveles de eficiencia judicial en materia del tratamiento del lavado de activos en el marco del nuevo sistema acusatorio: tanto en la identificación de las responsabilidades jurídico-penales, en el aseguramiento de los activos como en el tratamiento de las medidas de coerción personal.

Contenido:

1. Responsabilidades procesales del Fiscal y del Juez en el sistema acusatorio. La instrucción.

2. La libertad durante el proceso de investigación del lavado de activos 
3. Medidas cautelares en la instrucción o fase preparatoria del proceso penal
3. 1 Medidas personales
3.2 Medidas sobre bienes: incautación y decomiso
3.3 La incautación en la Ley 72-02
3.4 El decomiso en la Ley 72-02
$3.5 \quad$ Bienes susceptibles de estas medidas
3.6 Decomiso parcial. Situación de los bienes mezclados.
3.7 Comiso Sustitutivo y del valor por sustitución

4. La situación de los terceros de buena fé

5. Destino de los bienes decomisados

6. Los sistemas de valoración de la prueba y en particular sobre la valoración de medios de prueba en la investigación del lavado de activos
6.1 La prueba documental
6.2 La prueba testimonial
6.3 La prueba informativa
6.4 El peritaje
6.5 La prueba anticipada
6.6 El valor de los indicios
6.7 El valor de la declaración de un coimputado

7. Organismos estatales a los cuales el juez y el fiscal pueden pedir información en casos de lavado de activos
7.1 Unidad de Análisis Financiero
7.2 Banco Central
7.3 Superintendencia de Bancos
7.4 Dirección Nacional de Control de Drogas
7.5 Dirección General de Impuestos Internos
7.6 Dirección General de Migración
7.7 Registro Mercantil
7.8 Contraloría General de la República
7.9 Cámara de Cuentas
7.10 Oficina Nacional de Propiedad Industrial
7.11 Superintendecia de Valores
7.12 Otras Fuentes de Información Estatales

8. Organismos Privados de Utilidad Informativa
8.1 Entidades de Intermediación Financiera y Cambiarias
$8.2 \quad$ Organismos Internacionales
8.3 Empresas privadas de informaciones comerciales o de crédito

9. Régimen legal para la administración de los bienes incautados

10. Sugerencias para el desarrollo estratégico de la investigación de lavado de activos

10.1 El principio de oportunidad 


\section{MODULO VI:}

\section{ASISTENCIA JUDICIAL INTERNACIONAL EN EL MARCO DE LA INVESTIGACION Y ENJUICIAMIENTO DEL LAVADO DE ACTIVOS}

Olivo Rodríguez. Huertas

Objetivo específico:

Proporcionar los conocimientos indispensables para un efectivo uso de los mecanismos internacionales para recibir una adecuada asistencia judicial internacional en los procesos de investigación del lavado de activos.

Contenido:

1. Introducción: Ias implicaciones y posibilidades de la asistencia judicial internacional

2. La Convención de Viena de 1988

3. Convención de Palermo

4. Convención de Naciones Unidas contra la Corrupción

5. Convención Interamericana contra la Corrupción

6. Los Tratados Regionales sobre Asistencia Judicial Internacional

7. Tratados Bilaterales suscritos por República Dominicana

8. Aspectos sobre los que puede recaer la asistencia judicial internacional

8.1 Formas de remisión

8.2 Contenido de la solicitud

9. El reparto de bienes

10. La asistencia judicial internacional prestada por nuestras autoridades judiciales

11. Exigencias básicas de las cartas rogatorias en el Derecho comparado

12. Intercambio de información a través de Unidades de Inteligencia Financiera

13. La experiencia en materia de asistencia judicial internacional en casos que han sucedido en el derecho comparado

\section{MODULO VII:}

\section{LA INVESTIGACION FINANCIERA EN CASOS DE LAVADO DE ACTIVOS}

Heiromy Castro Milanés

Objetivo específico:

Ofrecer una visión de cómo se gesta el crimen del lavado de activos y proporcionar las herramientas de control preventivo y de detección de situaciones que, por su naturaleza, indicarán un fraude o anormalidad en la gestión de una empresa cualquiera. 
Contenido:

1. Introducción

2. Principales crímenes gestores del lavado de activos
2.1 El Narcotráfico
2.2 La corrupción
2.3 El tráfico de armas
2.4 El tráfico de seres humanos
2.5 El financiamiento del terrorismo

3. Investigación del lavado de activos
3.1 Unidad de Inteligencia Financiera
3.2 Unidad de Investigación Financiera
3.3 Indicios

4. Sistemas de transacción
4.1 En efectivo
4.2 De Negocios

5. Métodos de lavado de activos
$5.1 \quad$ Negocios Legítimos
$5.2 \quad$ Negocios llegítimos
5.3 Transacciones de compra y venta
5.4 Paraísos Fiscales
5.5 Sistemas financieros y cambiarios

6. Cómo rastrear el movimiento del dinero en una negociación
6.1 Composición, definición y naturaleza de los Estados Financieros
6.2 Análisis de posicionamiento
6.3 Análisis de los libros y registros
6.4 Métodos de rastreo de fondos
6.5 Información contable

7. Las Razones financieras como instrumentos analíticos e investigativos

8. Indicadores de Fraudes
8. 1 Cuarenta y seis (46) indicadores de fraudes
8.2 Prácticas contables inadecuadas en el ciclo de tesorería

9. Control interno
9.1
El Modelo COSO, para la prevención

10. La administración del riesgo

11. Implicaciones económicas y sociales del lavado de activos
11.1 Implicaciones económicas
12.1 Implicaciones sociales

12. Bibliografía Recomendada 



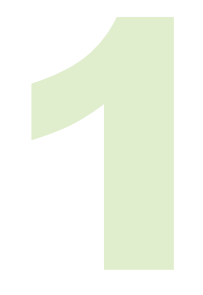

\section{LAVADO DE ACTIVOS GENERALIDADES}

Olivo Rodríguez, Huertas

\section{El problema criminológico del lavado de activos}

Cada día es más evidente, frente a los ojos de las economías mundiales como a los de la ciencia penal, que en el problema de lavado de capitales reside una de las cuestiones criminológicas de mayor gravedad institucional, gran impacto social y grave daño comunitario.

Como se ha advertido en los últimos años, el fenómeno no es novedoso y tampoco es una novedad la preocupación nacional e internacional que ha inducido al desarrollo de una verdadera política criminal de prevención y castigo de ese tipo de acciones delictivas.

La trascendencia criminológica del lavado de capitales ha evolucionado en directa relación con el aumento de los niveles de circulación económica que ha posibilitado y generado el crimen organizado, posiblemente, potenciado por los efectos nocivos de la llamada "globalización" que también ha llegado al fenómeno criminal.

Como lo ha afirmado en los últimos años un autor español: "No hace falta destacar la importancia y gravedad de una actividad delictiva que, sin exageración, se ha calificado como la gran lacra de la segunda mitad del siglo XX, ni de la alarma y preocupación generadas por la misma tanto entre los gobiernos como en la opinión pública de los países. Las vías y procedimientos para atajar este problema han sido y son temas de debate en todos los ámbitos. El desarrollo del narcotráfico en estos años se ha visto sin duda favorecido - y ahí radican probablemente las causas fundamentales de su crecimiento- por dos factores: por una parte, el desarrollo económico occidental, con el consiguiente aumento del nivel de vida, que ha propiciado un amplio mercado de potenciales consumidores (especialmente entre la juventud, que ha contado con los recursos económicos suficientes). Y por otra, el proceso de globalización de la economía, materializado en el fuerte crecimiento de los intercambios comerciales, el desarrollo de los transportes internacionales de mercancías, la liberalización 
del comercio internacional -con una reducción de las barreras arancelarias, una reducción igual de las restricciones cuantitativas y una creciente simplificación de las formalidades y los controles aduaneros- y la propia internacionalización del sistema financiero...) (todo ello ha permitido organizar la producción, distribución y comercialización de la droga a escala mundial, y no solamente a escala local como había venido sucediendo en épocas anteriores". 1

Sin lugar a duda puede afirmarse que de acuerdo a un conjunto de dimensiones, el problema del lavado de capitales presenta facetas criminológicas que lo ubican como un flagelo de enorme gravedad:

- En primer lugar es un problema grave tomando en consideración el impacto distorsionador que manifiesta en las economías mundiales.

- En segundo lugar, el lavado de dinero se expresa como un potenciador y estimulador de la delincuencia organizada.

- En tercer lugar, se nutre, en sistemas fuertemente globalizados, de las brechas que generan los diferentes niveles de control financiero que rigen las economías involucradas.

- En cuarto lugar, el fenómeno del lavado de dinero pone en evidencia las contradictorias valoraciones que surgen a menudo en países que, de modo a veces clandestino, observan a estos procesos como una alternativa de ingreso de capitales y de inyección económica a las alicaídas gestiones de los países subdesarrollados: lo que a veces genera visiones distintas en la relación Norte -Sur.

- En quinto lugar, existe una relación no lógica, sino empírica, entre el lavado de dinero y los niveles de transparencia en el ejercicio de la función pública.

- En sexto lugar, el agrandamiento del fenómeno criminal que describimos ha obligado a las economías nacionales a aumentar los niveles de injerencia y regulación, reduciendo el margen de discrecionalidad de la actividad privada, lo que constituía hasta hace poco tiempo una bandera indelegable del capitalismo bien entendido.

Todo ello exige que nos ocupemos, una vez más, pero adecuando ahora nuestro análisis a la legislación nacional, del fenómeno del lavado de capitales o de legitimación de activos.

\subsection{El punto de partida de la preocupación internacional}

Aunque desde principios de la década de los 80 del siglo pasado² existe constancia de la preocupación de instancias internacionales de gran relevancia por el fenómeno originado en los recursos provenientes de actividades ilegales, no fue sino hasta diciembre de 1988 cuando se produjeron dos documentos de trascendental importancia que marcarían, de manera concreta, el punto de partida de las iniciativas 
internacionales frente al problema.

Estos documentos fueron la Declaración de Principios del Comité para la Reglamentación Bancaria y las Prácticas de Vigilancia de Basilea, mejor conocida como la "Declaración de Basilea", emitida por los reguladores bancarios del Grupo de los Diez ${ }^{3}$ y formulada por los Reguladores Bancarios en fecha 12 de diciembre de 1988, así como la Convención de las Naciones Unidas contra el Tráfico llícito de Estupefacientes y Sustancias Psicotrópicas, mejor conocida como la Convención de Viena de ese mismo año.

La Declaración de Basilea tuvo por objetivo impedir que los bancos y otras instituciones financieras fueran utilizados para transferencias o depósitos de fondos de procedencia ilícita, a través de unas reglas de comportamiento, como la identificación de la clientela, la comprobación o averiguación de la conformidad de las transacciones a estándares éticos, la cooperación con autoridades judiciales, controles internos y adiestramiento del personal4.

La Convención de Viena de 1988, por su parte, refleja en su preámbulo el reconocimiento de la preocupación por el tema del lavado de activos proveniente del tráfico ilícito de drogas, al declarar las partes de la Convención estar conscientes "de que el tráfico ilícito genera considerables rendimientos financieros y grandes fortunas que permiten a las organizaciones delictivas transnacionales invadir, contaminar y corromper las estructuras de la administración pública, las actividades comerciales y financieras lícitas y la sociedad a todos sus niveles".

De ahí, que con la firma y ratificación de los Estados de la Convención de Viena, estos se obliguen a tipificar de una manera uniforme el delito de lavado de activos proveniente del tráfico de drogas 5 , proporcionándole la Convención mecanismos de asistencia judicial internacional que permiten perseguir a los delincuentes en cualquier parte del mundo, a través de la extradición6, así como incautar y/o decomisar7 en cualquiera de los países signatarios los bienes que tienen su origen o se deriven de un delito de tráfico de drogas.

A partir de este instrumento de Derecho Internacional, se crearon numerosos grupos de trabajos, mundiales y regionales, se propiciaron nuevos Convenios Internacionales de alcance universal, como los relativos a la Delincuencia Organizada Transnacional8, y la Corrupción`, y el resultado de esa preocupación internacional por el lavado de activos en la aldea global se podría resumir en los aspectos siguientes:

(a) ampliación del delito a recursos generados en una amplia gama de actividades delictivas, distintas del tráfico de drogas, capaces de generar igualmente inmensas cantidades de recursos;

(b) perfeccionamiento de la tipificación penal original, incorporando nuevos conceptos; mejorando y ampliando el alcance de los mecanismos de asistencia judicial internacional; 
(c) perfeccionamiento de las técnicas de prevención y ampliación de los sujetos obligados a su cumplimiento;

(d) establecimiento de instancias que faciliten un ágil sistema de intercambio de información financiera a través de las Unidades de Análisis o Inteligencia Financiera agrupadas en torno al Grupo Egmont; y

(e) creación de grupos de trabajo que se encarguen de monitorear permanentemente las técnicas utilizadas en los procesos de lavado de activos.

\section{Concepto: ¿Qué es el lavado de activos?}

Al igual que ocurre con otros términos, el lavado de activos no ha estado ajeno a la diversidad de conceptos respecto de su contenido u objeto. Por ello, nos limitamos en este punto a describir, algunas de las muy numerosas definiciones que ha generado la doctrina especializada sobre el tema.

En la obra El delito de lavado de capitales, su autor, el Prof. Isidoro Blanco Cordero10, define este comportamiento delictivo como "el proceso a través del cual bienes de origen delictivo se integran en el sistema económico legal con apariencia de haber sido obtenidos de forma lícita".

Otro jurista español, Diego J. Gómez Iniesta11, define el lavado de activos como "aquella operación a través de la cual el dinero de origen siempre ilícito es invertido, ocultado, sustituido o transformado y restituido a los circuitos económico-financieros legales, incorporándose a cualquier tipo de negocio como si se hubiera obtenido de forma lícita".

Para el francés Olivier Jerez 12 el lavado de activos es definido como "un conjunto de métodos legales o ilegales, un modus operandi, de complejidad más o menos variable según las necesidades del lavador, la naturaleza y el empleo de los fondos, a fin de integrar y disimular los fondos fraudulentos en la economía legal".

Paul Saint-Denis, abogado canadiense, considera el lavado de activos como el "proceso mediante el cual el producto de actos ilegales es convertido en activos que aparecen como legítimos, ocultando así su origen criminal" .13

Víctor Prado Saldarriaga 14, por su parte define el lavado de activos referido a recursos procedentes del tráfico de drogas, como "un conjunto de operaciones comerciales o financieras que procuran la incorporación al Producto Nacional Bruto de cada país, sea de modo transitorio o permanente, de los recursos, bienes y servicios que se originan o están conexos con transacciones de macro o micro tráfico ilícito de drogas". 
Por otra parte, la obra "Refugios Financieros, Secreto Bancario y Blanqueo de Dinero", elaborada por expertos 15 en el tema para la Oficina de las Naciones Unidas de Fiscalización de Drogas y de Prevención del Delito, recoge una definición que resume el lavado de activos en sus diversas fases: "Proceso dinámico en tres fases que requiere: en primer lugar, alejar los fondos de toda asociación directa con el delito; en segundo lugar, disfrazar o eliminar todo rastro; y, en tercer lugar, devolver el dinero al delincuente una vez ocultados su origen geográfico y ocupacional".

Finalmente, la jurista suiza Ursula Cassani16 señala que el lavado de activos "es el acto por el cual la existencia, la fuente ilícita o el empleo ilícito de recursos son disimulados con el propósito de hacerlos aparecer como adquiridos de forma lícita. Lavar dinero es reintroducirlo en la economía legal, darle la apariencia de legalidad y permitir así al delincuente disfrutarlo sin ser descubierto: el que lava dinero procedente de un delito ayuda por tanto al delincuente a aprovecharse plenamente del producto de su infracción".

\subsection{Distintas denominaciones utilizadas}

Las expresiones utilizadas en la denominación de este comportamiento delictivo indican que ella no es uniforme en la legislación, así como tampoco en la doctrina sobre el tema. Ello es así, porque el lavado de activos constituye "una realidad económica relativamente novedosa", "aunque existen neologismos en las principales lenguas para referirse a este delito". 17

En idioma inglés se utiliza la expresión "money laundering"; "blanchiment" en francés; "blanchissage" en suizo; "geldwasche" en alemán; "reciclaggio" en italiano; "Hsi ch'ien" en Chino; "Shikin no sentaku" en japonés; "otmyvanige" en ruso; y "branqueamento" en portugués.

Traducciones de algunas de esas expresiones se han trasladado a los países de habla hispana que utilizan las siguientes expresiones: "Lavado de Dinero-Lavado de Activos-Blanqueo de Capitales-Blanqueo de DineroLegitimación de Capitales".

En opinión de un autor "tres son las denominaciones acostumbradas en el plano internacional: "reciclaje", "blanqueo" y "lavado". La primera es traducción literal de riciclaggio y se estila en Italia y en la parte helvética de habla italiana. Respecto a la segunda, se utiliza en Bélgica y Francia (blanchitment), en Suiza francesa (blanchissage) así como en Portugal (branqueamento) y España. Por último, el término "lavado" es el más extendido y de él se sirven tantos los países anglófonos como Alemania, Austria y la Suiza de habla germánica, así como predomina, por proximidad geográfica a los EE.UU., en la mayor parte de los países sudamericanos". 18 


\section{Etapas del lavado de activos: Métodos comunes}

Un aspecto que distingue el lavado de activos, de otros delitos penales, lo constituye el hecho de que el mismo no se consume en un instante, sino que se efectúa por etapas.

La Convención de Viena de 1988, que fue pionera en las iniciativas internacionales en materia de lavado de activos provenientes del tráfico de drogas, configura las conductas típicas de este ilícito tomando en cuenta esa realidad comprendiendo todo el ciclo del proceso de lavado.

Otros Convenios Internacionales que recomiendan la tipificación del lavado de activos provenientes de otros actos ilícitos distintos del narcotráfico, como las Convenciones de las Naciones Unidas contra la Delincuencia Organizada Transnacional19 y contra la Corrupción20, siguen en términos muy parecidos la fórmula utilizada en la Convención de Viena de 1988.

Las etapas identificadas por el prestigioso e influyente Grupo de Acción Financiera (GAFI), que intervienen en el proceso del lavado de activos proveniente de actividades ilícitas, son las siguientes: colocación, enmascaramiento e integración. Estas etapas cumplen, en el ciclo de lavado de activos, las funciones que se señalan a continuación:

\subsection{Colocación}

El objeto perseguido por el lavador en esta etapa es desprenderse de las cuantiosas sumas en efectivo generadas por la actividad delictiva precedente. Para cumplir este objetivo el lavador debe hacer previamente un estudio del sistema financiero "a fin de distinguir las agencias de intermediación financiera que resultan más flexibles al control de las operaciones que realizan sus clientes, para luego, depositar en aquellas el dinero sucio y obtener instrumentos de pago como chequeras, tarjetas de crédito, cheques de gerencia, etc.". 21

En esta etapa, debido al alto nivel de riesgo de detección, "se precisa el empleo de varias personas y el concurso de muchas operaciones, lo que multiplica los riesgos. Superada esta fase, cuando el efectivo ya ha sido colocado en el circuito financiero y empiezan a intervenir las sociedades pantalla, las connivencias bancarias y otros recursos de enmascaramiento o integración, las evidencias materiales y rastros contables van desapareciendo y se hace casi imposible establecer el vínculo entre los fondos y su origen ilícito, de modo que difícilmente pueda detectarse el blanqueo a esa altura".22 
Los mecanismos corrientemente utilizados en esta etapa son los siguientes:

(1) A través de entidades financieras: Los delincuentes, a fin de evitar ser detectados por los controles preventivos impuestos a este tipo de entidades, suelen utilizar el fraccionamiento de sumas elevadas en otras de menor cuantía. La legislación dominicana, siguiendo el estándar utilizado en los Estados Unidos de América, establece la obligación del registro de todas las transacciones en efectivo que supere el equivalente en moneda nacional de la cantidad de diez mil dólares estadounidenses (US\$10,000.00)23, así como su reporte a una Unidad de Análisis Financiera, vía la Superintendencia de Bancos. Esta fase puede agotarse también a través de la complicidad de funcionarios y empleados de bancos, que inobservan las obligaciones puestas a su cargo, así como mediante la utilización de documentos falsos con la finalidad de disimular el origen o titularidad de los fondos.

(2) A través de "establecimientos financieros no tradicionales. Es el caso de las agencias de cambio, empresas dedicadas al canje de cheques, agentes de valores, negocios de ventas de joyas, metales preciosos, antigüedades y objeto de artes, estas cuatro últimas que comercializan objetos de "alto valor añadido, fácil transporte, titularidad anónima y pago habitual en efectivo".24

(3) Mezcla de fondos lícitos e ilícitos. Este mecanismo resulta especialmente utilizado en aquellos negocios que se caracterizan por el manejo habitual, dada su naturaleza, de recursos en efectivo, tales como estaciones de combustibles, restaurantes, supermercados, etc. Estos negocios suelen ser utilizados en la práctica como meras pantallas para poder justificar el depósito de cantidades significativas en efectivo. Lo que caracteriza esta forma de colocación de recursos en efectivo, proveniente de actividades delictivas es su mezcla con fondos que tienen su origen en operaciones lícitas25.

(4) Compra de bienes de alto valor. Los lavadores utilizan la compra de bienes de un alto valor pagando como contrapartida con recursos en efectivo. A título de ejemplo, la doctrina señala la compra de barcos, automóviles de lujo, aviones, obras de arte valiosas, etc.

(5) Contrabando de dinero en efectivo. Este es un mecanismo muy utilizado. Consiste generalmente en el desplazamiento de los recursos de fuente ilícita a lugares donde no existe regulación, ella es inapropiada o existiendo, los mecanismos de control no son muy efectivos. Este mecanismo ha sido erigido como un delito distinto de los de lavado de activos en nuestra legislación26.

Para el autor español Isidoro Blanco Cordero27, a pesar de que considera este mecanismo como muy común, y poco sofisticado, señala que en el futuro este método continuará y aumentará, ya que "como consecuencia de la globalización del mercado, y del aumento del volumen comercial mundial, es prácticamente imposible examinar todos los cargamentos que cruzan las fronteras, debiendo limitarse el control a una pequeña parte". 


\subsection{Estratificación o intercalación}

El objeto de esta segunda etapa del proceso de lavado de activos consiste en desligar los fondos ilícitos de su origen, generando para ello un complejo sistema de encadenamiento de transacciones financieras, encaminadas a borrar la huella contable de tales fondos ilícitos.

Para estos fines quienes se dedican a esta actividad ilícita recurren a la "multiplicidad de transacciones, multiplicidad de países y multiplicidad de personas y empresas".28 Estas "operaciones se realizan de modo veloz, dinámico, variado y sucesivo". 29

En esta etapa se utilizan tres mecanismos fundamentales: convertir el dinero en efectivo en instrumentos de pago; la reventa de los bienes adquiridos con los recursos en efectivo, y la transferencia electrónica de fondos.

(1) Conversión del dinero en efectivo en otros instrumentos de pago. Con esto se procura esencialmente dos cosas; una, facilitar el transporte de los recursos de un país a otro, y otra, facilitar el ingreso de los recursos en una entidad financiera, toda vez que las reglas de prevención están orientadas fundamentalmente a los recursos en efectivo.

(2) Reventa de los bienes adquiridos con dinero en efectivo. Ya vimos que en la primera etapa del proceso uno de los mecanismos utilizados por quienes se dedican a esta actividad es la adquisición de bienes, muebles e inmuebles, de un alto valor. Al vender estos bienes adquiridos con los recursos originados en la actividad delictiva, el lavador le otorga a los recursos recibidos un fundamento normal.

(3) Transferencia electrónica de fondos. El desarrollo de la tecnología facilita asimismo un ágil desplazamiento de los recursos, dificultando los rastros contables y en consecuencia la posibilidad de descubrir el origen ilícito de los mismos, sobre todo cuando se efectúan estas transferencias a instituciones ubicadas en paraísos fiscales o países no cooperadores en los esfuerzos internacionales contra el lavado de activos, "aprovechando la cobertura que proporciona la globalización financiera", 30

\subsection{Integración o inversión}

Esta constituye la etapa final del proceso de lavado de activos, en la que se procura la integración final de la riqueza obtenida en "los cauces económicos oficiales". ${ }^{31}$ Llegados a este estadio "Ios fondos de origen delictivo son ya muy difíciles de detectar, a menos que se haya podido seguir su rastro a través de las etapas anteriores", resultando "difícil distinguir los capitales de origen ilegal de los de origen legal",32 creándose la justificación o explicación de los bienes. 
Conforme al estudio del Grupo de Acción Financiera (GAFI), los métodos utilizados frecuentemente son los siguientes:

(1) Venta de inmuebles. La compraventa de inmuebles es considerada como uno de los vehículos más habituales del lavado de activos, debido a que se trata de bienes relativamente líquidos, con un valor muy difícil de estimar33, y con tendencias a apreciarse 34

En tal sentido, "la variedad de técnicas es muy amplia y van desde simples compras de propiedades residenciales o de negocios sin el intento específico de ocultar el propietario, hasta complejos sistemas donde las inversiones en bienes inmuebles son parte de una estrategia más amplia en la que se encuentran involucradas compañías pantalla". 35

(2) Empresas pantalla y prestamos simulados. A través de la llamada "técnica del préstamo de regreso", el delincuente se presta a si mismo. El mecanismo consiste en establecer una sociedad pantalla en un paraíso fiscal para prestarse los fondos que ha generado con motivo de la comisión de una actividad delictiva.

(3) Complicidad de banqueros extranjeros. El Grupo de Acción Financiera (GAFI), en su estudio sobre los métodos comunes utilizados en el lavado de activos, reconoce que uno de los mayores inconvenientes que se tienen en los esfuerzos frente al fenómeno lo constituye la complicidad de funcionarios y empleados de la banca. Como ha señalado Isidoro Blanco Cordero36, "mediante la participación de empleados bancarios bien situados en los sistemas de préstamos simulados o de regreso, el blanqueador puede obtener créditos aparentemente legítimos, asegurándolos con productos ilícitos. La ayuda complaciente del banco extranjero frecuentemente está protegida contra la investigación de las autoridades no solo por la duplicidad de criminales (el blanqueador de dinero y el banco extranjero cómplice) sino por las leyes bancarias y regulaciones de otro gobierno soberano, normalmente un paraíso fiscal".

(4) Falsas facturaciones de comercio exterior. Es un medio elemental y habitualmente utilizado para el lavado de activos, mediante la falsificación de facturas comerciales, la sobrevaloración de los documentos de entrada o de las exportaciones para justificar los fondos recibidos del extranjero.

\section{Características del lavado de activos}

El fenómeno criminológico del lavado de activos presenta una serie de características que son las que sirven de explicación a la trama del proceso que procura darle apariencias de legitimidad a recursos que tienen un origen ilegal. 
Esas características están relacionadas con la naturaleza internacional con que operan quienes se dedican a esta actividad ilícita, lo cuantioso de las sumas envueltas, la profesionalización de las organizaciones criminales a fin de estructurar transacciones financieras que permitan eludir a la autoridad de persecución, así como con las variadas técnicas que son empleadas para tal propósito.

\subsection{Naturaleza internacional}

Es obvio que el fenómeno del lavado de activos, como actividad que procura, a través de un proceso, darle respetabilidad a unos capitales que tienen su origen en la comisión de un delito, se vería en extremo limitado en ausencia de un entorno internacional liberalizado.

Esto es así, porque conforme se ha señalado a propósito de las etapas del proceso de lavado de activos y de Ios métodos utilizados en cada una de ellas, alejar el rastro delictivo originario de los recursos conlleva como nota importante un desplazamiento de los recursos del lugar donde se originaron, a fin de dificultar "su persecución por parte de las autoridades y facilitar su encubrimiento". 37

Quienes se dedican a esta actividad obviamente se benefician de la diversidad de los sistemas jurídicos sobre la materia en los distintos países del mundo, las deficiencias de sus contenidos, las debilidades institucionales, etc., que les permiten eludir a las autoridades de persecución, aprovechándose de esas lagunas.

Por ello, desde el primer llamado de atención sobre este fenómeno, la Recomendación R 80 del Comité de Ministros del Consejo de Europa, del 27 de junio de 1980, se deja ver la naturaleza internacional de los capitales que tienen un origen criminal, al reconocer que estos capitales son transferidos de un país a otro, por lo que, entre otros aspectos, recomendaba a los Estados miembros "establecer una estrecha colaboración, a través de la INTERPOL, entre los establecimientos bancarios y las autoridades competentes para intercambiar informaciones" 38 al respecto.

Igual reconocimiento contienen otros documentos internacionales de trascendencia, como la Convención de Viena de 198839, la Convención de Palermo del 2000, y la Convención de las Naciones Unidas contra la Corrupción del 200340, por solo citar instrumentos internacionales de alcance universal.

Nuestra vigente legislación sobre el lavado de activos contempla de manera precisa la naturaleza internacional de este tipo penal, al disponer en su artículo 5 que "las infracciones previstas en esta ley, así como los casos de incremento patrimonial derivados de actividades delictiva, serán investigados, enjuiciados, fallados como hechos autónomos de la infracción de que proceda e independientemente de que haya sido cometido en otra jurisdicción territorial". 


\subsection{Volumen del fenómeno}

Es prácticamente imposible señalar los montos que genera a escala mundial la delincuencia organizada, y que son objeto del proceso de lavado de activos, ya que debido a su naturaleza ilegal no se cuenta con estadísticas.

No obstante, organismos y grupos de importancia universal, como la Organización de las Naciones Unidas (ONU), el Fondo Monetario Internacional (FMI), así como el Grupo de Acción Financiera (GAFI), en informes y artículos sobre el tema han puesto de manifiesto que se trata de sumas verdaderamente extraordinarias.

Por ejemplo, se ha señalado que la ONU estimaba el lavado de activos proveniente del tráfico de drogas, al año 1996, en la cantidad de 300 mil millones de dólares. Por su parte, el FMI la ha situado, para el mismo año, pero ampliado a toda gama de actividad delictiva internacional, en la cantidad de aproximadamente 500 mil millones de dólares.

Por eso. Según Barral, "más allá de las diferencias que se observan en las distintas estimaciones que se han hado a título de ejemplo, y de la aproximación que efectivamente puedan reflejar respecto de las cifras reales, lo que resulta evidente es que, en cualquier caso, el volumen de la actividad revela la magnitud del fenómeno" 41 , por lo que atenta contra el orden social, económico y político de los países ${ }^{42}$, así como la estabilidad de los mercados financieros globales.

\subsection{Profesionalización}

El ex Secretario General de la Organización de las Naciones Unidas, Broutos Gali, llegó a considerar a la delincuencia organizada dedicada al lavado de activos como "una auténtica multinacional del delito".

Es lógico que, dados los altos volúmenes envueltos en el proceso de lavado de activos, y la complejidad que conlleva la estructuración de operaciones para tener éxito en insertar en el sistema económico legal con apariencia de legalidad activos que tienen un origen ilícito, se requiere que quienes estén al frente del diseño de las estrategias para tal propósito sean auténticos profesionales, de la banca, finanzas, contabilidad, leyes, que tengan por demás un amplio conocimiento del entorno regulatorio internacional sobre la materia, a fin de poder aprovechar las debilidades existentes en los distintos países que conforman la aldea global.

\subsection{Variedad y variación de las técnicas empleadas}

El éxito del lavado de activos requiere la utilización de una amplia gama de técnicas, a través de las cuales, en las distintas etapas del fenómeno, logren eludirse las regulaciones preventivas dispuestas por la autoridad. 
Es por ello que el Grupo de Acción Financiera (GAFI) monitorea y realiza informes anuales respecto de las técnicas usadas por los lavadores, con la finalidad de proporcionar a las autoridades que tienen responsabilidades en el campo persecutorio y preventivo las herramientas indispensables para el diseño de sus políticas.

En especial, es importante hacer referencia en lo que tiene que ver con la identificación de nuevos ejemplos de transacciones financieras sospechosas a ser tomados en cuenta por las entidades obligadas al cumplimiento de obligaciones de prevención.

Debido a que detrás de los métodos utilizados por la delincuencia organizada se mueve la autoridad de persecución, los lavadores se ven en la necesidad, ante tal monitoreo, de ser constantemente innovadores en sus estrategias para evitar que sus transacciones sean develadas por las autoridades y por los propios sujetos regulados.

Como ha señalado Isidoro Blanco Cordero, "la progresiva evolución de las técnicas de blanqueo de capitales es causa y consecuencia de una mayor profesionalización de las personas que las llevan a cabo. Esta característica se manifiesta en dos tendencias: mayor profesionalismo de los miembros de la organización y mayor empleo de profesionales externo. Ello es debido a la necesidad de minimizar riesgos de persecución penal y de maximizar oportunidades". 43

\subsection{Otras características}

La doctrina ${ }^{44}$ sobre el tema señala otras características del fenómeno del lavado de activos. Uno vinculado al modus operandi que emplea el agente, y otro, en función de los vínculos entre el agente del lavado y el origen ilegal del dinero lavado:

(a) Las personas que ejecutan las operaciones de lavado de activos generalmente no están vinculadas directamente a la ejecución del delito que genera las ilegales utilidades.

(b) La concretización y materialización del lavado de activos se realiza en el cumplimiento de los requisitos y procedimientos administrativos que son establecidos para cualquier actividad comercial o financiera del medio donde se desarrolle el proceso económico.

\section{Factores que han favorecido su desarrollo}

El desarrollo tan extraordinario del fenómeno del lavado de activos se produce en un contexto antes desconocido, que coincidencialmente ha generado las condiciones para el desarrollo de la delincuencia organizada. 
La globalización de la economía mundial, al procurar mecanismos ágiles y efectivos de intercambio de bienes y servicios en la aldea global, ha generado también una liberalización de los movimientos de capitales, una desregulación del sistema bancario de los países, lo que unido a las herramientas proporcionadas por la revolución tecnológica y la existencia de países con exenciones tributarias total y regímenes de anonimato, han creado las bases que han facilitado el desarrollo y expansión de modelos de criminalidad organizada.

\subsection{Globalización económica mundial}

La globalización de los mercados ha propiciado la oportunidad a las organizaciones criminales transnacionales de expandir sus actividades del plano local al ámbito internacional, convirtiéndose en uno de los "mayores actores en la actividad económica global y son los actores fundamentales en industrias ilegales, tales como la producción y el tráfico de drogas, del que obtienen beneficios superiores incluso al Producto Interior Bruto de muchos países desarrollados". 45

\subsection{Liberalización de los movimientos de capital y desregulación bancaria}

Un ágil intercambio de bienes y servicios a escala mundial requiere de manera indispensable una liberalización de los movimientos de capital, eliminando así las trabas y controles que obstaculicen su fácil circulación.

La supresión de los controles de cambios clásicos "privó a las autoridades nacionales de un instrumento importante que, aunque diseñado con otros fines, servía también en la lucha contra el blanqueo. Consecuentemente, esta liberalización, conveniente y necesaria por otra parte desde el punto de vista económico, ha obligado a las Administraciones nacionales a diseñar o reforzar otros instrumentos alternativos de investigación e información". 46

\subsection{Revolución tecnológica}

El avance tecnológico que se ha producido en las últimas décadas ha constituido otro importante aliado en los esfuerzos por agilizar el intercambio de bienes y servicios, en especial lo relativo a los medios de pago y en general a los movimientos de fondos.

Este avance ha repercutido extraordinariamente en el sistema bancario, desarrollando la banca electrónica, a través de los cajeros automáticos, el sistema SWIFT para la ejecución de órdenes de transferencia vía ordenadores o teléfono. Con ello ciertamente se acorta y facilita el proceso de ejecución de operaciones en el sistema bancario, pero se conspira con la obligación de identificación y conocimiento del cliente. 
En su informe anual 1995-1996, el Grupo de Acción Financiera (GAFI) se hizo eco del problema de la forma siguiente: "La aparición de nuevas tecnologías ofrece riesgos potenciales de blanqueo de dinero. Estas nuevas tecnologías pueden posibilitar la conducción de transacciones a gran escala de forma instantánea, remota y anónima, y pueden permitir que tales transacciones se efectúen sin implicar a las instituciones financieras tradicionales. Aunque no existe actualmente evidencia que indique esas nuevas tecnologías estén siendo utilizadas abusivamente de ese modo, el GAFI ha decidido afrontar activamente el problema instando a los países a tomar nota de la amenaza potencial planteada por las nuevas tecnologías y a adoptar las medidas apropiadas para minimizar dicha amenaza".

\subsection{Paraísos fiscales y secreto bancario}

Este aspecto representa uno de los puntos más débiles en los esfuerzos para enfrentar el fenómeno del lavado de activos, ya que los países que ofrecen la condición de paraísos fiscales se caracterizan por el anonimato de las transacciones, así como por una falta de cooperación con las autoridades de persecución. De manera, que cuando el lavador, haciendo uso de las facilidades que proporciona la revolución tecnológica unida a una liberación de capital y desregulación bancaria, logra transferir los recursos generados de actividades delictivas a países con estas características tiene altas posibilidades de insertar posteriormente con apariencia de legitimidad recursos de origen delictivo.

Así, "Ias ventajas que se derivan de las entidades bancarias de los paraísos fiscales son dos fundamentalmente: por un lado, permiten la apertura de cuentas secretas y numeradas, donde los nombres de los depositarios se encuentran separados de las cuentas; $y$, por otro, permiten también la constitución de entidades comerciales en las que el titular se mantiene en el anonimato (garantizado por el secreto profesional), siendo administradas por un agente comercial residente, y operan libres de impuestos". 47

\subsection{El desarrollo de modelos de criminalidad organizada}

En los últimos años la política criminal, por lo menos en el mundo occidental, comienza a plantear una redefinición de los modelos de investigación de ilícitos que desarrollan los Estados, sobre todo a partir de las cada vez más particulares exigencias de un tipo de ilicitud cuyos sistemas de organización, flujos de información, modelos de participación, planes de actuación, poderío económico y, por qué no, relación con el propio Estado, la caracterizan especialmente.

Este sector sociológico que, no sin cierta simplificación, se puede denominar como delincuencia organizada, plantea serias dificultades a una dogmática penal y procesal estructurada sobre la base de un sistema de actuación del Estado en la persecución criminal que no incluía, por lo menos teóricamente, ninguna de las figuras que aquí serán analizadas. 
Ello se manifestaba con claridad a la hora de superar ciertas restricciones legales y constitucionales para la valoración de la prueba - prueba ilícita u obtenida por medios no admitidos por el legislador o por el propio intérprete -, como así también cuando se deben superar los obstáculos del sistema de imputación - teoría del hecho punible - para la punición del "provocado" o "investigado" o encontrar alguna causa de impunidad - en el nivel sistemático que corresponda- para el agente "provocador" o "investigador".

Todo ello se justifica, además, internacionalmente, por ejemplo, cuando estos tipos de institutos son particularmente recogidos en la Convención de Viena sobre la represión al tráfico de sustancias estupefacientes, firmada el 19 de diciembre de 1988, quizá el primer instrumento del derecho internacional público que incorpora manifestaciones de un sistema de investigación y represión de ese tipo de delincuencia alejado del modelo tradicional, por ejemplo, el Art. 11 de la citada Convención establece la figura de la entrega vigilada:

"Si lo permiten los principios básicos de sus respectivos ordenamientos jurídicos internos, las Partes adoptarán las medidas necesarias, dentro de sus posibilidades, para que se pueda utilizar en forma adecuada, en el plano internacional, la técnica de entrega vigilada de conformidad con acuerdos o arreglos mutuamente convenidos, con el fin de descubrir a las personas implicadas en delitos tipificados de conformidad con el párrafo 1 del artículo 3 y de entablar acciones legales contra ellas."

Sin dudas, el concepto de delincuencia organizada ha obligado en los últimos años a modificar las herramientas político-criminales para su tratamiento. El lavado de dinero refleja uno de los ejemplos más nítidos de organización criminal. Algunos datos típicos de estas formas de organización son los siguientes:

- Altos niveles de infraestructura tecnológica y de sistemas de información.

- Planteles de recursos humanos con vocación a la permanencia.

- Estructuras de organización que exceden las fronteras nacionales.

- Alto nivel de poderío económico.

- Aseguramiento de ciertos niveles de impunidad originados en la relación con estructuras gubernamentales corruptas.

- Sistemas de administración con responsabilidades personales fragmentadas.

El delito de lavado de capitales o lavado de dinero ofrece ciertas características propias de este tipo de delincuencia organizada, y ello explica parte de la complejidad criminológica y político-criminal para su tratamiento desde el Estado. 


\section{Línea de acción}

Las iniciativas internacionales que han hecho frente al fenómeno criminal del lavado de activos trazan una línea de acción que está orientada como última ratio a privar a los delincuentes en el uso y disfrute de las inmensas ganancias originadas en la actividad delictiva, como una forma de desincentivar esos nocivos comportamientos.

A fin de cumplir con ese objetivo de política criminal, las recomendaciones procuran la penalización de las conductas de lavado de activos, la incautación y decomiso de bienes, la asistencia judicial internacional, desarrollos de modelos de investigación penal con capacidad de tratamiento de casos complejos, establecimiento de un régimen de prevención y sanciones administrativas a un conjunto de actividades comerciales y financieras susceptibles de ser utilizadas, y desarrollo de mecanismos de control y supervisión a escala internacional.

\section{1. Penalización del lavado de activos}

La penalización como conducta autónoma del lavado de activos se constituyo en uno de los objetivos centrales de la nueva políica criminal contra el tráfico de drogas a nivel mundial.

Por ello, la Convención de Viena de 1988, que es pionera en las iniciativas normativas internacionales en la materia, trazo la línea a seguir desde el punto de vista de la construcción del tipo penal del lavado de activos, con una recomendación que toma en cuenta las características del fenómeno y las etapas que en el intervienen:

(a) la conversión o la transferencia de bienes a sabiendas de que tales bienes proceden de alguno 0 algunos de los delitos tipificados o de conformidad con el inciso a) del presente párrafo, o de un acto de participación en tal delito o delitos, con objeto de ocultar o encubrir el origen ilícito de los bienes o de ayudar a cualquier persona que participe en la comisión de tal delito o delitos a eludir las consecuencias jurídicas de sus acciones;

(b) la ocultación o el encubrimiento de la naturaleza, el origen, la ubicación, el destino, el movimiento o la propiedad reales de bienes, o de derechos relativos a tales bienes, a sabiendas de que proceden de alguno o algunos de los delitos tipificados de conformidad con el inciso a) del presente párrafo 0 de un acto de participación en tal delito o delitos;

Salvo ligeras variantes, en los instrumentos normativos internacionales que siguieron en importancia a esta Convención, como las Convenciones de las Naciones Unidas contra la Delincuencia Organizada Transnacional, y contra la Corrupción, recogen, con ligeras diferencias, esas fórmulas, aunque lógicamente ampliando su radio de acción más allá del tráfico de drogas. 
El propósito de establecer un modelo de tipificación del lavado de activos obedece a la característica internacional del fenómeno, por lo que se hace necesario una homogeneidad entre las legislaciones del mundo.

La Ley 19/1993 de 28 de diciembre de España, en el Capítulo I Artículo 2do. señala que se entenderá por lavado de capitales la adquisición, utilización, conversión o transmisión de bienes que procedan de alguna de las actividades delictivas enumeradas en el apartado anterior (drogas, bandas armadas, organizaciones 0 grupos terroristas, bandas o grupos organizados) o de participación en las mismas para ocultar o en encubrir su origen 0 ayudar a la persona que haya participado en la actividad delictiva a eludir las consecuencias jurídicas de sus actos, así como la ocultación o encubrimiento de su verdadera naturaleza, origen, localización, disposición, movimientos o de la propiedad o derechos sobre los mismos, aun cuando las actividades que las generen se desarrollen en el territorio de otro Estado.

En el Acta de Delitos vinculados al Narcotráfico 1986 del Reino Unido de Gran Bretaña e Irlanda de Norte: en la sección 24 de Drugs Trafficking Offences Act, se incrimina la conducta como quien sabiendo o sospechando que una persona ha traficado con drogas o se ha beneficiado con el tráfico de drogas, participa en actos que configuran la retención o control de fondos originados en ese delito, coloca esos fondos, a disposición de cliente o los utiliza para adquirir bienes o cosas..."

En el Acta del 11 de enero de 1993, de Bélgica, se dispone que se acata la directiva de la C.E.E. (Comunidad Económica Europea) del 10 de junio de 1991 (91/308 EE.UU.) para prevenir el uso del sistema financiero como herramienta del lavado de dinero y define el lavado de dinero como la conversión o transferencia de dinero 0 bienes con el propósito de ocultar o disimular su origen ilícito o de asistir a cualquier persona que esté envuelta en actividades criminales, utilizando el dinero directamente o otras actividades derivadas de su colocación y ayudándola a evadir las consecuencias legales de sus acciones.

También lo define como la ocultación o disimulo de la naturaleza, origen, localización, disposición, movimiento, propiedad de dinero o bienes, sabiendo que es derivado de actividades criminales, así como su adquisición y posesión.

Señala, entre otras, como actividades criminales (Sect. 505, 2a. 3ro, y 4to. PC) el terrorismo, las organizaciones criminales, el tráfico ilícito de narcóticos, el contrabando, la prostitución, los fraudes bancarios, etc.

La ley francesa 90-614, del 12 de julio de 1990, tipifica el lavado de dinero dentro de aquellas actividades que limitan la figura penal a casos de narcotráfico. Sigue los lineamientos de la Convención de Viena de 1988. Obliga a informar, como en todos los casos ya mencionados, ciertas operaciones denominadas sospechosas 
y que presentan características inusuales. Con posterioridad y para cumplir con recomendaciones realizados por el Grupo de Acción Financiera Internacional (GAFI), el Parlamento amplió las disposiciones de la Ley de 1990 señalando que la declaración de sospechas por parte de los bancos y demás organismos financieros se extiende a las operaciones financieras que parezcan provenir de la actividad de organizaciones criminales.

Australia basa su legislación en Recomendaciones contenidas en "Proceeds of Crimes Act" de 1987 y la "Financial Transaction Reports Act" de 1988. Asimismo, Australia es miembro de la Financial Action Task Force (FATF), por lo que participa activamente en la promoción sobre estrategias para combatir el lavado de activos y la necesidad de cooperación a escala internacional para atacar al crimen organizado. Ha definido el lavado de dinero, como la participación directa o indirecta en una transacción en que estén involucrados bienes o cosas derivados de un acto delictivo, cuando la persona supiere o debiera razonablemente saber el origen de los mismos.

Tomando en cuenta que para poder tipificar al lavado de dinero como un delito se requiere la utilización de código penal de un país, Estados Unidos ha promulgado diversas disposiciones a fin de encuadrar dentro de su marco jurídico al lavado de dinero o diversas actividades relacionadas con el mismo.

La tipificación del lavado de dinero se efectúa dentro de la Ley Antidrogas de 1986, cuyas disposiciones básicas están contenidas en las secciones 1956 y 1957 del Título 18.

Bajo los términos del Título 18, fracción 1956 de USC, es ilegal implicarse en una operación financiera relacionada con las ganancias producto de una actividad estipulada como "ilícita", cuando el objeto de esa actividad sea el fomentar la misma u ocultar la fuente y propiedad de los fondos, o el evitar el cumplimiento de la obligación de informar dicha transacción de acuerdo a normas federales o estatuales.

De conformidad con el Título 18, fracción 1957 de USC, se considera que comete delito "quien a sabiendas realice 0 intente realizar una transacción monetaria con bienes derivados de un ilícito por más de US\$10.000 y ese dinero sea producto de un ilícito específico."

Además, la Ley contra el Abuso de Drogas de 1986 prohíbe la estructuración de operaciones monetarias con el fin de evadir los requerimientos de reporte de moneda.

Asimismo, el Título 26, fracción 6050I de USC, requiere que cualquier individuo implicado en el comercio 0 negocio que reciba una cantidad mayor a US\$10.000, producto de una sola operación, deberá presentar el reporte de la misma al Servicio Interno de Rentas (IRS). 
Por otra parte, ya desde 1970 normas destinadas a combatir el crimen organizado imponían a los bancos la obligación de reportar toda transacción en efectivo superior a US\$10.000.

Existe actualmente para las instituciones financieras la obligación de presentar diversos reportes vinculados con las actividades que ellas desarrollan, tales como CTR USC 5313 informe sobre transacciones en moneda estadounidense en efectivo por sumas superiores a US\$10.000, USC 5314 informe sobre transacciones efectuadas por un residente con una entidad financiera extranjera, USC informe sobre transacciones en moneda extranjera, USC 5316-CMIR informe sobre la entrada y salida de instrumentos monetarios o efectivo por montos superiores a los US\$10.000, etc.

Dentro de ámbito del MERCOSUR, el tema de lavado de dinero, a instancias de Brasil, se viene tratando como un elemento de discusión más en la agenda de trabajo de los Bancos Centrales de los respectivos países miembros.

Por tal motivo, en la década de los 90 se ha prestado suma atención a este proyecto de ley a los efectos de tratar de compatibilizar definiciones, tipificaciones y pautas similares en atención a las implicancias que leyes tan importantes y especiales pueden llegar a tener dentro del MERCOSUR.

La República Dominicana, que ratificó la Convención de Viena de 1988, a partir del año 1995 incorporó en términos parecidos a dicha Convención el lavado de activos, mediante la Ley 17-95, aunque como un delito conexo de los delitos de tráfico de drogas.

La Ley 72-0248, que constituye el marco jurídico vigente del lavado de activos en nuestro país, consagra las distintas conductas típicas del fenómeno; extiende el lavado de activos a recursos originados en una amplia gama de actividades delictivas; reconoce la naturaleza autónoma del delito y aplica los criterios de justicia universal al sancionar las conductas de lavado de activos sin importar el lugar donde se cometió el delito previo que generó los recursos 49 .

\subsection{Incautación y decomiso de bienes}

La incautación, para fines de posterior decomiso, de los bienes que tienen su origen en actividades ilícitas constituye un objetivo de primera importancia en la estrategia para combatir la delincuencia organizada transnacional. 
Es por ello que, en el mismo preámbulo de la Convención de Viena de 1988, se afirma lo siguiente:

"Conscientes de que el tráfico ilícito genera considerables rendimientos financieros y grandes fortunas que permiten a las organizaciones delictivas transnacionales invadir, contaminar y corromper las estructuras de la administración pública, las actividades comerciales y financieras lícitas y la sociedad a todos sus niveles";

"Decididas a privar a las personas dedicadas al tráfico ilícito del producto de sus actividades delictivas y eliminar así su principal incentivo para tal actividad".

De manera, que la identificación, rastreo y ubicación de los bienes que tienen su origen en las actividades delictivas graves, sin importar el lugar donde se encuentren, constituye un objetivo primordial en la política criminal en la materia como un mecanismo de debilitamiento de las organizaciones criminales delictivas que operan a nivel internacional.

A fin de no afectar el comercio jurídico de los bienes, y en consecuencia a los terceros que de buena fe hayan efectuado transacciones con los mismos, las legislaciones50 sobre el tema, siguiendo las recomendaciones internacionales, han previsto el comiso sustitutivo, cuando se haga imposible el decomiso de un bien debido a una acción u omisión del procesado.

\subsection{Asistencia judicial internacional}

Un punto clave en la estrategia para enfrentar la criminalidad organizada internacional lo constituye el establecimiento de un marco jurídico que permita una ágil asistencia judicial internacional.

Como ya se ha señalado en otra parte de este módulo, lo que facilita el fenómeno criminal del lavado de activos es el ámbito internacional en que opera con la finalidad de darle apariencia legítima a bienes cuyo origen es delictivo.

Por ello, todos los instrumentos normativos internacionales consagran de forma detallada la asistencia judicial en la materia, ya que constituye un mecanismo indispensable para obtener los elementos probatorios necesarios, así como cumplir con uno de los objetivos de política criminal en el tema como lo constituye el privar a los delincuentes del uso y disfrute de los bienes obtenidos productos de su ilícita actividad, que generalmente se encuentran en jurisdicciones territoriales diferentes a la del lugar donde se esté juzgando al delincuente. 


\subsection{Desarrollo de modelos de investigación penal para casos complejos}

No cabe duda que la investigación del delito de lavado de capitales, según lo que venimos exponiendo, debe presentar dificultades adicionales para su investigación, sobre todo si tenemos en cuenta que el sistema procesal de República Dominicana todavía remite a ciertos paradigmas inquisitivos que deben ser superados. Aquí sólo se remarcarán algunas sugerencias para el desarrollo de modelos de investigación eficientes en casos de delitos complejos como el que se analiza.

Se encuentra cada vez más difundida la concepción que le atribuye al Estado serias falencias de capacidad instrumental para poner en funcionamiento un sistema de investigación de los delitos de impacto económico, que cumpla las siguientes características: equitativo, eficaz, transparente, y con cierta posibilidad técnica de detectar este tipo de ilícitos antes de que se dañe de modo irremediable el bien jurídico protegido. Esta última dimensión lesiona cualquier posibilidad de instalar un modelo de prevención general negativa o positiva. De este modo no habrá ninguna intimidación y tampoco se confirmará el valor protegido por la ley penal 72-02 que reprime el lavado de dinero.

Por otro lado, la ausencia o la debilidad de los programas racionales de control y orientación del gasto público de los últimos años, sin duda, había colaborado a fomentar la idea de que los ciudadanos no tienen un deber tan fuerte de "asociarse" con el sistema de control económico, teniendo en cuenta que tampoco el Estado trasladaba los tributos a una mejora en la calidad de vida de sus ciudadanos.

En este contexto de crisis ética, social y económica, es preciso, repensar un modelo de política criminal en esta materia. Se trata de desarrollar un plan de política criminal, vinculado con el problema que plantea este tipo de ilícito, que tome en cuenta estos datos con la finalidad de que el derecho penal económico no se transforme en un fin en sí mismo sino en una parte trascendente de los instrumentos de que dispone el Estado para desarrollar políticas sociales.

Algunos de los síntomas son los siguientes: falta de un modelo estratégico para la selección de los casos que se denuncian, ausencia de un plan de política criminal para el lavado de dinero, carencia de un modelo de optimización de la información que se produce en cada caso denunciado y que tramita en el sistema judicial.

Estas falencias forman parte de un diagnóstico que no debe ser eludido sino enfrentado con firmeza.

Este tipo de decisiones puede significar, de acuerdo a como se desarrolle el propio camino de su puesta en funcionamiento, o una nueva experiencia de más de lo mismo o el comienzo de una transformación de envergadura en los niveles de eficiencia en la tramitación de los delitos complejos o de impacto económico. 
Debemos tener en cuenta hoy día, por otro lado, que gran parte de la consolidación definitiva de un modelo eficiente en el control de las conductas aquí analizadas, depende de la creatividad y profundización del sistema de relaciones que genere con las instancias de control administrativo y/o judicial.

La primera reacción, vinculada con este punto de partida, debe remarcar una advertencia: el fortalecimiento institucional de todos los organismos de control (judiciales y administrativos) depende del establecimiento de una red de apoyo mutuo.

Es indudable que, a diferencia de los organismos que ejercen el poder, los que controlan la legitimidad de ese poder no tienen incorporada ya en la pila bautismal su propia vitalidad, sino que requieren llevar como una preocupación fundacional las reales posibilidades de desarrollar cierta capacidad de gestión.

En ese sentido, esas instancias de control deben potenciarse en la implementación de un modelo de trabajo de red institucional que asegure, más allá de las eventuales y muchas veces declarativas autonomías de cada organismo, la vitalidad institucional suficiente como para enfrentarse con éxito a las conductas ilícitas o económicamente dañosas. En la América Latina y el Caribe, la ineficiencia de los organismos estatales y de la justicia a la hora de investigar, perseguir y sancionar delitos de gran impacto económico ha quedado demostrada en más de una ocasión y es ya imprescindible una búsqueda de solución creativa.

A lo largo de estos años, los intentos de los sucesivos gobiernos por hacer más eficaz la acción de los Estado en la lucha contra la delincuencia organizada ya parecieran, una y otra vez, estar destinados al fracaso de antemano. Este diagnóstico debe ser corregido.

Ahora bien, la débil capacidad institucional de los Estados para llevar adelante políticas efectivas y eficientes de investigación, control y persecución de los delitos complejos estaba directamente relacionada con una serie de falencias factibles de detectar en el orden organizacional, operativo y de recursos humanos en los sectores involucrados. Veamos, tan solo, algunas de las más sobresalientes:

- Falta de coordinación entre los organismos estatales responsables de la identificación, selección, investigación y seguimiento de los casos (especialmente, entre el Ministerio Público Fiscal y los organismos administrativos).

- Duplicación de tareas, esfuerzos y costos, especialmente, en la conformación de una base de datos informativa.

- Desaprovechamiento de los instrumentos de información y medición de las operaciones sospechosas existentes y escaso cruzamiento de datos fiables. 
- Carencia, en muchas dependencias, de apoyo técnico (no jurídico) de calidad, capaz de comprender las maniobras utilizadas, conocer adecuadamente la documentación involucrada y desarrollar un alto compromiso con la función desarrollada.

- Ineficiencia del sistema de enjuiciamiento penal para dar respuesta cualitativa a casos de gran impacto económico.

Este diagnóstico debe ser enfrentado en forma clara por las autoridades políticas:

(1) Mejorando las actividades de coordinación.

(2) Aumentando y optimizando los recursos de investigación especializada, incluso en el ámbito administrativo.

(3) Desarrollando actividades de capacitación.

(4) Mejorando el apoyo técnico.

(5) Mejorando los sistemas de investigación procesal.

(6) Generando la posibilidad procesal de seleccionar los casos que serán sometidos a investigación y juicio.

Sin embargo, y a pesar de todas estas medidas, está comprobado que las estrategias públicas de investigación requieren del sector privado (sobre todo financiero) para aumentar la eficiencia de las mismas. En algunos países desarrollados, han comenzado a experimentarse novedosos diseños de alianzas entre los sectores públicos y privados para atacar más eficazmente estos males. En este marco, las empresas han comenzado a asumir tareas de definición, desarrollo e implementación de sus propios mecanismos de prevención y control de este tipo de conductas.

En la convicción de que un mercado transparente es altamente conveniente para el florecimiento de la economía y del bienestar, los actores privados (sociedad civil y empresas) deben asumir cierta cuota de responsabilidad, ya que este mercado solo será transparente en la medida que ninguna empresa pueda atribuir un porcentaje de sus pérdidas o de la disminución de sus ganancias a la evasión tributaria, el lavado de dinero, la corrupción 0 el contrabando de quienes compiten.

Los ejemplos abundan "Los principios de Wolfsberg contra el Lavado de dinero", que detallan el acuerdo alcanzado por un importante grupo de bancos privados (asistidos por un equipo de Transparency International, al que se incorporaron los expertos Stanley Morris y Prof. Mark Pieth) en el sentido de estipular un modelo consensuado de prevención del lavado de capitales, es una de las muestras recientes. 
Allí se establecieron lineamientos que se ocupan de temas como: identificación de clientes, de beneficiarios y/o usufructuarios de cuentas; realización de estudios sobre administradores monetarios; evaluación técnica (due diligence) para la apertura de cuentas; exigencias de conocimiento fidedigno del cliente para los casos de cuentas numeradas; procedimientos especiales para países y actividades de "alto riesgo"; verificación minuciosa para funcionarios públicos; actualización de archivos de clientes; determinación de actividades sospechosas: a) transacción de la cuenta u otras actividades que no resultan consistentes con los datos recopilados en la evaluación técnica, b) transacciones en efectivo por encima de cierta suma, y c) transacciones "de paso" que entran y salen; determinación de mecanismos para detectar otros tipos de actividades también sospechosas (monitoreo de transacciones, contactos con el cliente, información de terceros, conocimiento interno del banquero privado sobre el entorno del cliente); determinación de las acciones a seguir en caso de identificar una actividad inusual (monitoreo más intenso, cancelación de la relación comercial, información de la relación comercial a las autoridades); desarrollo de modelos de monitoreo y control, desarrollo de programas de educación; capacitación e información, y establecimiento de departamentos especiales para la prevención del lavado (compliance officer).

La preocupación de la banca privada es razonable con sólo pensar en algunos de los ejemplos internacionales: en el Reino Unido, el mayor poder dado por una nueva ley al Financial Services Authority -FSA- ha implicado la amonestación de 15 bancos por sus débiles medidas de prevención del lavado en la recepción de fondos del dictador nigeriano Sani Abacha y de su entorno.

Se sugiere que desde el Estado y los sistemas de investigación judicial se fomente este tipo de actitud privada y se desarrollen estrategias comunes. Aquí el interés estatal y el privado coinciden.

Ello puede lograrse a través de la aplicación de una serie de herramientas y mecanismos de prevención e investigación:

- Propiciando acuerdos horizontales que sean impuestos al Estado para que asuma su rol de garantía.

- Fomentando la realización de denuncias ante los diversos organismos encargados de canalizarlas.

- Llevando a cabo, periódicamente, diagnósticos conjuntos de la situación según el sector de actividad.

- Manteniendo reuniones estratégicas con las diferentes agrupaciones empresarias, Cámaras industriales y/o gremios que permitan definir convenios para combatir este tipo de delitos.

- Instalando el problema y difundiendo los resultados de estas reuniones.

- Definiendo planes de acción de cara a los medios de comunicación masiva, logrando que estos traten el tema o difundan importantes denuncias sobre casos testigos. 


\section{- Sensibilizando a la ciudadanía sobre la problemática.}

El sector empresarial debe comprender que la legítima protección y defensa de sus intereses (privados) generan efectos altamente oxigenantes no sólo en el mismo mercado sino también en la sociedad de manera más amplia.

En el mercado porque al evitar distorsiones propias del juego de la evasión, el contrabando y del lavado de dinero, y al disminuir las amenazas de pérdidas, se fortalece y se vuelve más eficiente. En la sociedad porque promueve reglas claras e incentiva el respeto por las normas, dos valores básicos de las sociedades desarrolladas. Además, como "by product" de su accionar legítimo mejora la calidad de vida de todos los ciudadanos.

Es necesario, entonces, el desarrollo de una verdadera políitica criminal de prevención y el castigo del lavado de dinero.

Aquí sólo se señalarán, de modo resumido, algunas necesidades que, una vez satisfechas, permitan sentar las bases de un nuevo modelo de gestión en este ámbito político criminal analizado:

\section{Un modelo estratégico para la selección de los casos que se denuncian}

Un análisis ya superficial del sistema de investigación penal del delito de lavado de dinero demuestra que, más allá del número total de casos tramitados ante el sistema judicial, no se advierte un modelo de selección (o mejor dicho prioridad) de aquellos casos que son llevados al sistema penal.

No parecía que los casos que son denunciados respondan a una estrategia de política criminal y ello, naturalmente, no es muy razonable teniendo en cuenta que la Administración no tiene chances fácticos ni burocráticos de llevar en forma eficiente la totalidad de los casos jurídico-penalmente relevantes al sistema judicial.

Un sistema de selección es imprescindible. Sólo hay que discutir sobre la implementación de uno que sea transparente, eficiente y que sea sistémico con las diferentes estrategias de política criminal que expone la Administración Central.

\section{Un plan de política criminal en este ámbito}

Cuando se menciona la necesidad de una política criminal se pretende insistir en ciertas dimensiones 
imprescindibles:

(a) Definición precisa de recursos y de las necesidades de investigación y prevención.

(b) Establecimiento de pautas de prioridad tomando en cuenta la situación por sector y el tipo de maniobra.

(c) Definición de estrategias de prevención en forma coordinada con los objetivos de investigación penal.

(d) Formulación de estrategias procesales y de modelos de criterios de éxito.

Esta ausencia de una verdadera política criminal tiene efectos altamente nocivos a la hora de buscar caminos para un aumento de la eficiencia del sistema penal en esta dimensión.

\section{Un modelo de optimización de la información que se produce en cada caso denunciado al sistema judicial}

Por otro lado, se advertía la ausencia de un modelo que permita el aprovechamiento de la información que se adquiere ante cada caso denunciado, sobre el tipo de maniobra que se investiga. No debiera extrañar que la información que se produce en un caso judicial pudiera significar un gran aporte en otro caso judicial que se tramita en forma simultánea pero con autonomía. El no aprovechamiento debe ser imputado a un problema de matriz deficiente y es preciso que sea solucionado.

En buena cantidad de ocasiones el Estado tiene información valiosa y suficiente sobre eventuales hechos ilícitos, pero que sólo produce efectos cuando los diferentes bancos de datos son analizados en conjunto y luego de determinados cruzamientos. Ello en lo que respecta, por ejemplo, al ilícito de "lavado de activos" o al delito tributario es decididamente determinante.

La política criminal no es otra cosa que una de las más trascendentes políticas de control y, desde este punto de vista, muchas veces debe asumir el rol de "última ratio" o último eslabón en la cadena de reacciones estatales y supeditarse a los objetivos de control de las instancias administrativas, para lo cual debe haber una adecuada coordinación.

En muchas ocasiones los hechos que son evaluados por los controles administrativos no son otra cosa que ilícitos de enorme gravedad e impacto social y llegan a conocimiento del organismo adecuado luego de un tiempo excesivo. La información que se ha obtenido sobre el hecho, a menudo, no es la que se requiere para la formación de la imputación penal

En este sentido, la eficiencia de la investigación penal preparatoria muchas veces depende de una buena coordinación administrativa y/o judicial. 


\subsection{Régimen de prevención y sanciones administrativas}

El lavado de activos es un fenómeno extraordinariamente complejo. De ahí que los esfuerzos para combatirlo eficazmente, a diferencia de las conductas delictivas tradicionales, se efectúen en dos ámbitos que lucen en principio contradictorios, aunque en realidad se complementan, como lo constituye la represión y la prevención 51 .

La prevención cumple dos objetivos fundamentales: uno, evitar que una serie de actividades de naturaleza financiera o empresarial en sentido general sean afectadas en su reputación y solvencia por quienes se dedican a pretender darle legitimidad a unos capitales de origen criminal y, dos, porque de cara a los procesos penales de lavado de activos facilitan importantes elementos probatorios.

Las legislaciones recogen el régimen de prevención estableciendo un conjunto de obligaciones, como la relativa a la identificación y conocimiento de los clientes, registro y reporte de transacciones en efectivo que superen un determinado monto, reporte de transacciones sospechosas, sean estas efectuadas 0 no, con recursos en efectivo, conservación de documentos durante un período de tiempo no inferior a cinco (5) años, establecimiento de mecanismos y órganos de control, así como la capacitación de su personal, obligaciones estas que deben ser cumplidas por las actividades comerciales, empresariales y financieras que determine la legislación.

A fin de hacer efectivo el cumplimiento de estas obligaciones, las legislaciones se preocupan por erigir su desconocimiento, en ilícitos administrativos que dan lugar a la aplicación de sanciones administrativas, tanto a los funcionarios o empleados directamente responsables del incumplimiento, como a la propia entidad, independientemente de que si como resultado de los mismos se haya incurrido o no en una actividad de lavado de activos.

\subsection{Establecimiento de mecanismos de evaluación multilateral}

Dentro de los mecanismos de evaluación multilateral, sin lugar a dudas, el Grupo de Acción Financiera Internacional, se ha convertido en la instancia más relevante. El GAFI ha sido fundado por los Jefes de Estado y de Gobierno del Grupo de los Siete en Paris en julio de 1989, con el objetivo de estudiar y promover las medidas destinadas a combatir el lavado de capitales procedentes en forma protagónica del tráfico de drogas.

Se encuentra compuesto por tres grupos de trabajo: uno dedicado al análisis de la extensión y métodos del banqueo de capitales, otro a cuestiones jurídicas y judiciales y el tercero a la cooperación administrativa y financiera. 
EI GAFI no puede tomar decisiones ejecutivas, pero sus recomendaciones tienen una fuerza práctica muy trascendente. En el marco de las primeras 40 recomendaciones, el GAFI se ha ocupado de los sistemas legislativos, de la cooperación multilateral, del papel del sistema financiero, de la relación de los delitos originarios, etc.

Otros organismos multilaterales que se han ocupado o se ocupan del problema del lavado de capitales, aunque de modo más coyuntural, son el Comité Europeo de la Lucha contra la Droga (CELAD), que desarrolló un plan para esta materia que fue aprobado por el Consejo Europeo en Roma en el año 1990, y el propio Consejo de Ministros de la Comunidad.

Por otro lado es de destacar el denominado "Egmont Group" que agrupa a las diversas Unidades de Información Financiera (84 en total), y que constituye una amplia red que articula vínculos de cooperación en el intercambio de información y, también, en materias relativas a la capacitación, infraestructura, prevención, etc.

Asimismo, debe resaltarse el trabajo de la Comisión Interamericana para el Control del Abuso de Drogas de la OEA -CICAD/OEA. Los grupos de expertos de la CICAD formulan recomendaciones a los Estados miembros a los efectos de mejorar su capacidad en el control de estas conductas. 
1 Álvarez Pastor, Daniel; Eguidazu Palacios, Fernando, La prevención del blanqueo de capitales, Aranzadi Editorial, Pamplona, 1998, pág. 21 y ss.

2 El 27 de junio de 1980 el Comité de Ministros del Consejo de Europa emitió la Recomendación R (80), relativa a medidas contra la transferencia y el encubrimiento de capitales de origen criminal, al estimar "que la transferencia de capitales de origen criminal de un país a otro y su blanqueo mediante su reinserción en el circuito económico suscitan graves problemas, favorecen la comisión de nuevos actos delictivos y extienden así mismo el fenómeno tanto en el plano nacional como en el internacional". Asimismo, la Organización de las Naciones Unidas en un documento elaborado en 1982, titulado "Estrategias y Políiticas Internacionales de Fiscalización de Drogas", entre las alternativas para la reducción del tráfico ilícito de drogas sugería "identificar transacciones financieras vinculadas al tráfico ilícito de drogas y disponer que las sentencias garanticen la pérdida, por los traficantes, de cualquier beneficio que hubieren obtenido. Se debe examinar otras medidas posibles para privar a los infractores del producto de sus delitos".

3 Este grupo lo conformaban Bélgica, Canadá, Francia, Alemania Federal, Japón, Italia, Países Bajos, Reino Unido, Estados Unidos, Suecia y Suiza.

4 Esta Declaración tuvo gran influencia en la elaboración futura por parte del Grupo de Acción Financiera (GAFI) de las obligaciones de prevención no sólo a los bancos y demás instituciones financieras, sino también a otra amplia gama de actividades empresariales susceptibles de ser utilizadas en el proceso del lavado de activos.

5 Víctor Prado Saldarriaga, en un interesantísimo trabajo titulado "La criminalización internacional del lavado de dinero: Sus desarrollos regionales y nacionales", señala que en el primer proyecto de Convención contra el Narcotráfico elaborado por la Comisión de Estupefacientes de la ONU, en 1985, no se consideraba entre las conductas criminalizables al lavado de dinero. "Sin embargo, ya en junio de 1986, al aparecer un nuevo "Proyecto de Convención contra el Tráfico llícito de Estupefacientes y Sustancias Psicotrópicas", la Comisión de Estupefacientes de la ONU propone que el lavado de dinero pase a ser considerado como un delito autónomo".

6 El Art. 6.3 de la Convención de Viena dispone: "Si una Parte que supedita la extradición a la existencia de un tratado recibe de otra Parte, con la que no lo vincula ningún tratado de extradición, una solicitud de extradición, podrá considerar la presente Convención como la base jurídica necesaria para la extradición respecto de los delitos a los que se aplica el presente artículo".

7 Art. 7.2, letra g) de la Convención.

8 Aprobada en la ciudad de Palermo, Italia, en diciembre del año 2000.

9 Aprobada en la ciudad de Mérida, México, en diciembre del año 2000.

10 Pág. 93

11 El delito de blanqueo de capitales en el Derecho Español, Cedecs Editorial, 1996, pág. 21.

12 "Le blanchiment de I'argent", Revue Banque Edition, pág. 25.

13 Citado por Saen Montero, Manfred, en el artículo "El Secreto Bancario y el Lavado de Dinero en Costa Rica". Revista de Ciencias Penales, año 9 , número 13, pág. 89.

14 El Delito de Lavado de Dinero en el Perú, pág. 2.

15 Los autores son Jack A. Blum, Michael Levi, R.T. Taylor y Phil Williams.

16 Cassani, U., Le blanchissage d'argent.Fiches Juridiques Suisses, Genéve, febrero, 1994.

17 Aranguez Sánchez, Carlos. El delito de blanqueo de capitales. Editorial Marcial Pons, pág. 21.

18 Abel Souto, Miguel. El blanqueo de dinero en la normativa internacional. págs. 32 y ss.

19 En este punto seguimos la obra La Prevención del Blanqueo de Capitales, de Daniel Pastor Álvarez y Fernando Eguidazu Palacios, Editorial Arazandi. Págs. 33 y ss.

20 Artículo 6: Penalización del blanqueo del producto del delito:

1. Cada Estado Parte adoptará, de conformidad con los principios fundamentales de su derecho interno, las medidas legislativas y de otra índole que sean necesarias para tipificar como delito, cuando se cometan intencionalmente:

a) i) La conversión o la transferencia de bienes, a sabiendas de que esos bienes son producto del delito, con el propósito de ocultar o disimular el origen ilícito de los bienes o ayudar a cualquier persona involucrada en la comisión del delito determinante a eludir las consecuencias jurídicas de sus actos;

ii) La ocultación o disimulación de la verdadera naturaleza, origen, ubicación, disposición, movimiento o propiedad de bienes o del legítimo derecho a éstos, a sabiendas de que dichos bienes son producto del delito;

b) Con sujeción a los conceptos básicos de su ordenamiento jurídico: 
i) La adquisición, posesión o utilización de bienes, a sabiendas, en el momento de su recepción, de que son producto del delito;

ii) La participación en la comisión de cualesquiera de los delitos tipificados con arreglo al presente artículo, así como la asociació y la confabulación para cometerlos, el intento de cometerlos, y la ayuda, la incitación, la facilitación y el asesoramiento en aras de su comisión.

21 Esta Convención utiliza la misma fórmula de la Convención de Palermo del año 2000, en su Art. 23.1

22 Prado Saldarriaga, Víctor. El Delito de Lavado de Dinero en el Perú, pág. 4.

23 Barral, Jorge E. Legitimación de bienes provenientes de la comisión de delitos. Editorial Ad Hoc, pág. 35.

24 Art. 41, numeral 4, de la Ley 72-02: Reporte de transacciones en efectivo: Comunicar, dentro de los primeros quince (15) días de cada mes, mediante formularios o a través de soporte magnético a la Unidad de Análisis Financiero, vía la Superintendencia de Bancos, para las instituciones que estén bajo la supervisión de esta entidad, todas las transacciones en efectivo realizadas en el mes anterior que superen la cantidad de diez mil dólares de los Estados Unidos de América (US\$10,000.00) u otra moneda extranjera o su equivalente en moneda nacional, calculado sobre la base de la tasa oficial de cambio establecida por el Banco Central de la República. Las transacciones múltiples en efectivo realizadas en una o más oficinas de la misma entidad, que en su conjunto superen la cantidad de diez mil dólares de los Estados Unidos de América (US\$10,000.00) u otra moneda extranjera o su equivalente en moneda nacional. Serán agrupadas y consideradas como una transacción única, si son realizadas en beneficio de una misma persona, física o moral, durante un día laborable. En tal caso, dichas transacciones deben ser reportadas a la Unidad de Análisis Financiero.

25 Álvarez Pastor, Daniel, ob. cit., pág. 36.

26 El Art. 5.6 de la Convención de Viena de 1988, establece que "cuando el producto se haya mezclado con bienes adquiridos de fuentes lícitas, sin perjuicio de cualquier otra facultad de incautación o embargo preventivo aplicable, se podrán decomisar dichos bienes hasta el valor estimado del producto mezclado". De igual forma se expresa nuestro legislador, al disponer en el párrafo II del Art. 31, de la Ley 72-02 que "cuando las propiedades obtenidas o derivadas directa o indirectamente de un delito han sido mezcladas con propiedades adquiridas de forma lícita, el decomiso de estas será ordenado solo por el valor de los bienes, productos o instrumentos del delito".

27 La Ley 72-02, dispone en su artículo 8, que será sancionada con la pena contemplada en el Capitulo de las sanciones: "a) la persona, nacional o extranjera, que al ingresar o salir del territorio nacional, por vía aérea, marítima o terrestre, portando dinero o títulos valores al portador o que envíe los mismos por correo público o privado, cuyo monto exceda la cantidad de diez mil dólares, moneda de los Estados Unidos de América (US\$10,000.00) u otra moneda extranjera, o su equivalente en moneda nacional no lo declare o declare falsamente su cantidad en los formularios preparados al efecto". 28 Ob. cit., pág. 67.

29 Jaramillo-Vallejo, Jaime. Lavado de activos: Temas de Política Pública, pág. 7.

30 Prado Saldarriaga, Víctor. El delito de lavado de dinero en el Perú. Pág. 4.

31 Barral, Jorge E. Legitimación de bienes provenientes de la Comisión de Delitos, pág. 33.

32 Fabian Caparros, Eduardo. El delito de blanqueo de capitales, pág. 149.

33 Álvarez Pastor, Daniel. La prevención del blanqueo de capitales, pág. 38.

34 Ibidem.

35 Blanco Cordero, Isidoro, ob. cit, pág. 74.

36 Blanco Cordero, Isidoro. ob. cit., págs. 74 y 75.

37 Ob. cit., págs. 75 y 76.

38 La Prevención del Blanqueo de Capitales, pág. 28.

39 Jerez, Olivier. ob. cit., pág. 172.

40 En su preámbulo reconoce que el tráfico ilícito de drogas es una actividad delictiva internacional cuya supresión exige urgente atención y la más alta prioridad.

41 En su preámbulo reconoce "que la corrupción ha dejado de ser un problema local para convertirse en un fenómeno transnacional que afecta a todas las sociedades y economías, lo que hace esencial la cooperación internacional para prevenirla y luchar contra ella".

42 Barral, Jorge E. Legitimación de bienes provenientes de la comisión de delitos.

43 Es por ello que en el preámbulo de la Convención de Viena de 1988, las partes se declaran "conscientes de que el tráfico ilícito genera considerables rendimientos financieros y grandes fortunas que permiten a las organizaciones delictivas transnacionales invadir, contaminar y corromper las estructuras 
de la administración pública, las actividades comerciales y financieras lícitas y la sociedad a todos sus niveles".

44 Ob. cit., pág. 52.

45 Prado Saldarriaga, Víctor, artículo citado, pág. 2.

46 Blanco Cordero, Isidoro, ob. cit., pág. 38.

47 Álvarez Pastor, Daniel, ob. cit., pág. 31.

48 Blanco Cordero, Isidoro, ob. cit., págs. 63 y 64.

49 Ley 72-02 establece las conductas típicas del lavado de activos en la forma siguiente: Art. 3.- A los fines de la presente ley, incurre en lavado de activos la persona que, a sabiendas de que los bienes, fondos e instrumentos son el producto de una infracción grave: (a) Convierta, transfiera, transporte, adquiera, posea, tenga, utilice o administre dichos bienes; (b) Oculte, encubra o impida la determinación real, la naturaleza, el origen, la ubicación, el destino, el movimiento o la propiedad de dichos bienes o de derechos relativos a tales bienes; (c) Se asocie, otorgue asistencia, incite, facilite, asesore en la comisión de alguna de las infracciones tipificadas en este artículo, así como a eludir las consecuencias jurídicas de sus acciones.

50 Ley 72-02: Art. 5.- Las infracciones previstas en esta ley, así como los casos de incremento patrimonial derivados de actividad delictiva, serán investigados, enjuiciados, fallados como hechos autónomos de la infracción de que proceda e independientemente de que hayan sido cometidos en otra jurisdicción territorial.

51 El Art. 32 de la Ley 72-02 sobre lavado de activos dispone lo siguiente: "Cuando cualquiera de los bienes, productos o instrumentos, como resultado de cualquier acto u omisión del condenado, no pudieren ser decomisados, el tribunal ordenará el decomiso de cualesquiera otros bienes del condenado, por un valor equivalente u ordenará al mismo que pague una multa por dicho valor".

52 Para Javier Zaragoza Aguado "es comúnmente aceptado que una estrategia global contra el blanqueo de capitales de origen ilícito requiere un marco normativo apropiado en dos vertientes, radicalmente distintas pero complementarias entre sí: por un lado, en la persecución penal de estas conductas y en el decomiso del producto derivado de esas ilícitas actividades con el objetivo de conseguir la desarticulación de las organizaciones criminales, el enjuiciamiento y castigo de sus miembros, y la privación de sus ganancias y beneficios (aspecto represivo); y por otro lado, en el aumento de los niveles de transparencia y de control en el sistema económico y comercial con la finalidad de reducir la vulnerabilidad del propio sistema y de impedir su utilización en el desarrollo de esta actividad (aspecto preventivo)". Derecho Penal Económico, pág. 371. 



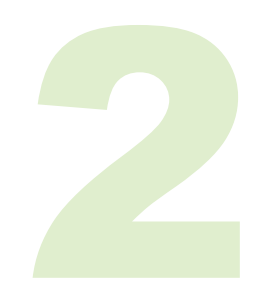

\section{MARCO INTERNACIONAL DEL LAVADO DE ACTIVOS}

Olivo Rodríguez, Huertas

\section{Introducción}

El lavado de activos es un fenómeno de naturaleza internacional. Es por ello que las grandes iniciativas adoptadas para enfrentarlo, normativas o no, tengan igual dimensión o alcance.

El objetivo de tipificar como un delito autónomo, el lavado de activos, tiene como propósito la desarticulación de las estructuras delincuenciales transnacionales, al privarlas del uso y disfrute de las inmensas ganancias que le reportan determinadas actividades delictivas. El patrimonio resultante de esas ganancias ilícitas generalmente se encuentra disperso por toda la aldea global.

Esta realidad es la que ha motivado a la comunidad internacional a estructurar un marco jurídico que permita a los Estados contar con instrumentos normativos, de naturaleza multilateral o bilateral, que posibiliten una eficaz cooperación o asistencia judicial internacional para la detección, incautación y posterior decomiso de los bienes objeto del proceso de lavado de activos, sin importar los lugares donde se encuentren, así como la ubicación de pruebas que sirvan de soporte a los procesos penales.

En esa línea se inscriben varios Tratados o Convenios Internacionales suscritos a partir del año 1988.

Pero, además, el compromiso de enfrentar este comportamiento delictivo no se limita, dada su complejidad, a la represión de las conductas de lavado de activos, sino que se extiende también al campo preventivo. De ahí que grupos de relevancia, universal y regional, de las esferas públicas y privadas, promuevan, a través de declaraciones y recomendaciones, la necesidad de establecer mecanismos y controles, de naturaleza preventiva con relación a un conjunto de actividades empresariales y profesionales proclives a ser utilizadas en el proceso que procura dar apariencia de legitimidad a recursos originados en actividades delictivas, como son las 
entidades de intermediación financiera, casas de cambio de monedas, casinos, loterías, empresas de bienes raíces, etc. ${ }^{1}$.

Estas iniciativas en el ámbito preventivo se extienden también a monitorear el grado de cumplimiento y la vulnerabilidad de los sistemas económicos de los Estados, originando en ocasión ser catalogados como países no cooperadores, lo que en una economía interdependiente le genera a esos países serias dificultades para la inversión internacional, limitando así sus posibilidades de desarrollo.

\section{El impacto normativo interno de la legislación internacional}

La Constitución de la República, en su Art. 3, dispone: "La República Dominicana reconoce y aplica las normas del Derecho Internacional general y americano en la medida de que sus poderes públicos las hayan adoptado".

La capacidad para celebrar Tratados de acuerdo a nuestra Carta Fundamental es una prerrogativa del Jefe del Estado, el Presidente de la República (Art. 55). No obstante, una vez concertados, para vincular al Estado es necesario que las Cámaras Legislativas impartan su ratificación. De manera que se trata de un acto complejo en el que intervienen dos poderes del Estado: Ejecutivo y Legislativo.

La República Dominicana ha suscrito todos los Convenios Internacionales de alcance universal y regional que contienen disposiciones relativas al lavado de activos, como lo constituyen la Convención de Viena de 1988, la Convención de Palermo del 2000, la Convención de las Naciones Unidas contra la Corrupción del 2003, la Convención Interamericana contra la Corrupción de 1998, así como el Convenio Centroamericano para la prevención y la represión de los delitos de lavado de dinero y de activos relacionados con el tráfico de drogas. No obstante, solamente el primero, y los dos últimos han sido objeto de ratificación por parte del Congreso Nacional, por lo que forman parte de nuestro ordenamiento jurídico interno.

\subsection{Jerarquía normativa de los compromisos internacionales asumidos: dualismo y monismo}

La determinación de la proyección normativa que tienen los Tratados o Convenios Internacionales en el Derecho interno se ha manejado en la doctrina y jurisprudencia internacional sobre la base de dos concepciones: una, la teoría monista, y otra, la dualista.

La primera de ellas (doctrina monista) parte de la base de la unidad del conjunto de las normas jurídicas. Se acepta el principio de la subordinación, según el cual todas las normas jurídicas se encuentran subordinadas las unas a las otras, en un orden rigurosamente jerárquico. 
Por su parte, la doctrina dualista, considera que al Derecho Internacional y al Derecho interno como dos sistemas de Derecho iguales, independientes y separados, que no se confunden y que, por tanto, no existe superioridad de un derecho sobre otro.

La Corte Permanente de Justicia Internacional, refiriéndose a este tema, en el caso "Polonia vs. Empleados Dantzig" señaló que "según un principio bien establecido de derecho internacional, el acuerdo, siendo un tratado internacional, no puede como tal crear directamente derechos y obligaciones para particulares. Pero no puede negarse que el objeto mismo de un acuerdo internacional, conforme a la intención de las partes contratantes, puede ser la adopción por las partes de algunas reglas definidas que creen derechos y obligaciones para los individuos y sean susceptibles de ser aplicadas por los tribunales nacionales".

Hoy día no es objeto de discusión la incorporación de los Tratados Internacionales en el Derecho interno. Sin embargo, el punto en conflicto resulta de la diversidad del tratamiento en las Constituciones a este tema. Unas consideran que las disposiciones de los Tratados, una vez incorporados en el Derecho interno siguiendo el trámite constitucional para ello, tienen el mismo rango que las disposiciones de la Constitución. Otras les otorgan un rango inferior a la Constitución, pero superior a la Ley, y algunas otorgan a los Tratados el mismo rango jerárquico que la Ley, por lo que una Ley posterior al Tratado que contenga disposiciones contrarias a este último implica derogación.

Esto último desde luego nos lleva a otro principio que resulta clásico en el Derecho Internacional, el de la fuerza obligatoria de los Tratados en aplicación de la máxima latina "pacta sunt servanda". Eso lo reconoce el propio preámbulo de la Convención de Viena sobre Derecho de los Tratados al señalar que "los principios del libre consentimiento y de la buena fé y la norma pacta sunt servanda están universalmente reconocidos". Como ha señalado un autor, Jean Hostert, la regla pacta sunt servanda es un principio de costumbre, justicia, moral y derecho internacional.

Vinculado estrechamente al principio pacta sunt servanda, está el principio de buena fé. Como ha señalado el internacionalista colombiano, Marco Monroy Cabra, en su Derecho Internacional Público, publicado por la Editorial Temis, el de buena fé es un principio ético y de derecho, que se impone a los Estados, independientemente de toda Convención. Es un principio indispensable para poder garantizar la seguridad internacional y para evitar la simulación y el engaño en las relaciones internacionales.

Continúa señalando el mismo autor: "Este principio implica para los Estados la obligación de respetar no sólo la letra, sino el espíritu del tratado, absteniéndose de ejecutar actos que desvirtúen su genuino sentido o que lo contraríen". 
Todo lo anterior nos conduce al principio de preeminencia de los Tratados sobre el Derecho interno que consagra el Art. 27 de la Convención de Viena sobre Derecho de los Tratados, cuando señala que una parte "no podrá invocar las disposiciones de su derecho interno como justificación del incumplimiento de un Tratado".

En ese sentido es de resaltarse, una sentencia de la Corte Suprema de Justicia de Argentina, del 7 de julio de 1992, en el caso Ekmekdjian c/Sofovich, en el que señala que "Ia ratificación de un Tratado Internacional es un acto complejo, donde participan necesariamente el Poder Ejecutivo y el Legislativo; por tanto la derogación de un tratado internacional por una ley del Congreso violenta la distribución de competencias impuesta por la propia Constitución, lo que importaría un avance inconstitucional del Poder Legislativo sobre las atribuciones del Poder Ejecutivo. La Convención de Viena sobre el Derecho de los Tratados confiere primacía al derecho internacional Convencional sobre el Derecho interno. La necesaria aplicación del Art. 27 de la Convención de Viena impone a los órganos del Estado argentino asignar primacía al Tratado ante un eventual conflicto con cualquier norma interna contraria".

\subsection{Tratamiento jurisprudencial en República Dominicana sobre la jerarquía interna de los Tratados Internacionales}

En nuestro país no es objeto de discusión la vinculación jurídica que originan las normas contenidas en Tratados o Convenios Internacionales una vez han sido ratificados por el Congreso Nacional, dado el claro contenido del Art. 3 de la Constitución de la República.

Sin embargo, la ubicación jerárquica de los Tratados en nuestro sistema de normas ha sido objeto de tratamiento por parte de la jurisprudencia de nuestro más alto órgano de justicia, la Suprema Corte de Justicia.

La posición tradicional asumida por la jurisprudencia dominicana estuvo orientada a considerar que los Tratados o Convenios Internacionales tienen una jerarquía similar a la de la ley, por lo que una Ley interna, desde el punto de vista de su contenido, contraria a un Tratado Internacional implicaba la derogación parcial de este último.

No obstante, recientemente nuestra Suprema Corte de Justicia, en una histórica Resolución, la No. 1920-2003, del 13 de noviembre del 2003, ha considerado que en nuestro País existe el denominado bloque de constitucionalidad, al cual está sujeta la validez formal y material de toda legislación adjetiva o secundaria:

"Atendido, a que la República Dominicana, tiene sistema constitucional integrado por disposiciones de igual jerarquía que emanan de dos fuentes normativas esenciales: a) la nacional, formada por la Constitución y la jurisprudencia constitucional local tanto la dictada, mediante el control difuso como 
por el concentrado, y b) la internacional, compuesta por los pactos y Convención es internacionales, las opiniones consultivas y las decisiones emanadas de la Corte Interamericana de Derechos Humanos; fuentes normativas que en su conjunto, conforme a la mejor doctrina, integran lo que se ha denominado, el bloque de constitucionalidad, al cual está sujeta la validez formal y material de toda legislación adjetiva o secundaria".

Esa declaración de nuestra Suprema Corte de Justicia constituye un cambio radical en lo que había sido la postura tradicional de nuestra jurisprudencia respecto de la jerarquía de los Tratados o Convenios Internacionales, cuyas disposiciones, desde el punto de vista de su fuerza normativa interna, las equipara a las disposiciones contenidas en la propia Constitución.

\section{Principales órganos internacionales y grupos de trabajo sobre lavado de activos}

Los esfuerzos para enfrentar el fenómeno del lavado de activos han conllevado una participación activa y diversa, en la que se conjuga la participación pública y privada, aunque, desde luego, el liderazgo de estos esfuerzos con ribetes universales ha sido asumido por organismos internacionales y regionales:

(a) Organización de las Naciones Unidas (ONU). Esta organización es la que ha auspiciado los principales instrumentos internacionales aplicables al lavado de activos, como lo son la Convención de las Naciones Unidas contra el Tráfico Ilícito de Estupefacientes y Sustancias Psicotrópicas (Convención de Viena de 1988); la Convención de las Naciones Unidas contra la Delincuencia Organizada Transnacional (Convención de Palermo del 2000); y la reciente Convención de las Naciones Unidas contra la Corrupción del 2003.

(b) Consejo de la Unión Europea. Como hemos dicho más arriba, otros organismos multilaterales que se han ocupado o se ocupan del problema del lavado de capitales son el Comité Europeo de la Lucha contra la Droga (CELAD) y el propio Consejo de Ministros de la Comunidad.

(c) Organización de Estados Americanos (OEA). Esta organización ha jugado un rol de primera importancia en los esfuerzos desarrollados a nivel del continente americano frente al problema del lavado de activos. A través de su Comisión Interamericana para el Control del Abuso de Drogas (CICAD), constituyó un Grupo de Expertos en materia de lavado de activos que elaboró el Reglamento Modelo, un instrumento que ha tenido una importancia extraordinaria en las legislaciones de los distintos países del continente y, de manera particular, en la Ley 72-02 sobre Lavado de Activos de la República Dominicana.

(e) Grupo de Acción Financiera (GAFI). Se trata de un grupo de trabajo creado por el G-7, conformado por los países más industrializados, en fecha 16 de julio de 1989. Este grupo emitió las 40 
recomendaciones que han tenido una influencia decisiva en los esfuerzos frente al lavado de activos a escala mundial, tanto en el aspecto represivo como preventivo.

El GAFI ha revisado sus recomendaciones y, como consecuencia de los terribles acontecimientos de naturaleza terrorista ocurridos en las ciudades de Nueva York y Washington el 11 de septiembre del año 2001, ha emitido 8 recomendaciones adicionales atinentes a la financiación del terrorismo.

(†) INTERPOL. La Organización Internacional de Policía Criminal (INTERPOL) ha jugado roles de fundamental importancia en los esfuerzos para enfrentar el lavado de activos a escala internacional, a través de la cooperación y asistencia judicial internacional. En el año 1983, cuando aún no había surgido ningún instrumento de alcance universal respecto del problema de fondos de origen criminal, la INTERPOL creó un grupo especializado, conocido como Fondos Procedentes de Actividades Criminales (FOPAC), que investiga los fondos provenientes de las organizaciones criminales y que elaboró un documento denominado "Enciclopedia Financiera".

(g) Grupo Egmont. Se trata de un grupo integrado por importantes bancos, de distintas nacionalidades, que operan en el ámbito internacional. Han funcionado bajo la coordinación de la importante organización mundial Transparencia Internacional.

Este grupo ha emitido los importantes principios de Wolsbergt, así como recomendaciones especiales atinentes al financiamiento del terrorismo.

(h) Grupo de Acción Financiera del Caribe (GAFIC). Tiene su origen en una Conferencia sobre lavado de activos que tuvo lugar en Aruba, del 8 al 10 de junio de 1990, en la que se emitieron 19 Recomendaciones sobre la materia. Cuenta con una Secretaría que vela por la implementación de dichas Recomendaciones así como las 40 Recomendaciones del GAFI. Entre las principales actividades que despliega se encuentran un mecanismo de autoevaluación respecto del grado de cumplimiento de las Recomendaciones, la coordinación de programas de entrenamiento y asistencia técnica, y la organización de reuniones ministeriales anualmente.

(I) Grupo de Acción Financiera de Sudamérica (GAFISUD). Es un grupo regional latinoamericano surgido en Cartagena de Indias, Colombia, en diciembre del año 2000, ante la amenaza que representa para la estabilidad económica, política y social de la región, la indebida utilización del sistema financiero por parte de organizaciones criminales transnacionales. Este grupo cuenta con tres órganos rectores: el Consejo de Autoridades, que es el órgano supremo; el Pleno de Representantes, que está compuesto por los delegados de cada Estado miembro, y la Secretaría que tiene su sede en Buenos Aires y está a cargo de las funciones técnicas y administrativas. Procura enfrentar el fenómeno del lavado de activos desde la óptica represiva y preventiva.

(j) Grupo Asia/Pacífico sobre Lavado de Activos (APG). Este grupo fue creado en febrero de 1997, en el curso de una reunión que tuvo lugar en Bangkok. Al igual que el GAFIC cuenta con una Secretaría 
Ejecutiva, y entre sus misiones están la de prestar asistencia a sus miembros en la elaboración de leyes que tipifiquen el lavado de activos, establezcan mecanismos de asistencia judicial internacional y contemplen un sistema de incautación y decomiso de bienes; y la conformación e instalación de unidades de inteligencia financiera, entre otros aspectos.

(k) Grupo contra el Lavado de Activos en África Oriental y del Sur. Se trata de un cuerpo regional actualmente integrado por 14 países. Su propósito es aplicar las 40 Recomendaciones del GAFI con el objetivo de preservar la estabilidad económica, social y política de la región. Está conformado por el Consejo de Ministros, el Grupo de Trabajo de Oficiales Senior y una Secretaría.

\section{Diversidad de instrumentos internacionales}

Si algo caracteriza las iniciativas internacionales de cara a los esfuerzos frente al lavado de activos es su diversidad.

Encontramos, por una parte, auténticas normas que comprometen o vinculan a los Estados, como lo constituyen los Tratados o Convenios Internacionales, unos de alcance universal y otros de naturaleza regional.

Por otra, Declaraciones y Recomendaciones de grupos de importancia, a escala planetaria y regional, sobre distintos aspectos englobados dentro del tema, cuya trascendencia obedece a la importancia de los países o instituciones que lo conforman.

Asimismo, propuestas normativas que procuran la homogeneidad en las legislaciones de los países del mundo en materia de lavado de activos, cónsono con la naturaleza eminentemente internacional de este fenómeno delictivo.

En cuanto a los Tratados Internacionales, como la Convención de las Naciones Unidas contra el Tráfico llícito de Estupefacientes y Sustancias Psicotrópicas, el Convenio de Estrasburgo, la Convención Interamericana contra la Corrupción, así como la Convención de las Naciones Unidas contra la Delincuencia Organizada Transnacional, conocida también como la Convención de Palermo, lo que caracteriza dichos instrumentos internacionales desde el punto de vista jurídico es su carácter vinculante, ya que constituyen auténticos compromisos de los Estados, cuya inobservancia, una vez han sido ratificados, es capaz de comprometer la responsabilidad internacional del Estado infractor.

Por su parte, la importancia de las Declaraciones y Recomendaciones, como la Declaración del Consejo de Europa de 1980, la Declaración de Basilea de 1988, las 40 Recomendaciones del Grupo de Acción Financiera 
(GAFI), las 19 Recomendaciones del Grupo de Acción Financiera del Caribe (GAFIC), la Declaración Política y Plan de Acción contra el Lavado de Activos adoptada por la Organización de las Naciones Unidas (ONU), así como los recientes Principios de Wolfsberg, más que jurídica deviene, como ya se ha señalado, de la trascendencia de los países o instituciones que conforman los organismos o grupos internacionales que las han auspiciado.

Igual sucede con las propuestas normativas auspiciadas, una, a escala global como lo es el Modelo de Ley para elaborado por la ONU, y otra, a nivel del Continente Americano, auspiciada por la Comisión Interamericana para el Control del Abuso de Drogas (CICAD) de la Organización de Estados Americanos (OEA), denominada Reglamento Modelo.

\section{Tratados Internacionales}

Diversos son los Tratados Internacionales vigentes a la fecha que resultan de interés en los esfuerzos para prevenir y sancionar el lavado de activos. Unos tienen un alcance universal, otros regional, fundamentalmente en el ámbito europeo y americano.

\section{1. Tratados de alcance universal:}

\subsubsection{Convención de Viena de 1988}

El nombre correcto de esta Convención es "Convención de las Naciones Unidas contra el Tráfico llícito de Drogas, Estupefacientes y Sustancias Psicotrópicas". La misma quedó abierta a la firma de los Estados, en el centro de conferencias de Neue Hofburg, Viena, el 20 de diciembre de 1988. Entró en vigor el 11 de noviembre de 1990, cuando fue depositada por España su instrumento de ratificación, completándose así la cantidad de 20 ratificaciones indispensables, según la propia Convención, para su entrada en vigencia.

La República Dominicana firmó la Convención de Viena, pero no fue sino hasta el 30 de mayo de 1993 que el Poder Ejecutivo promulgó la ratificación realizada por el Congreso Nacional mediante la Resolución 7-93.

Esta Convención constituyó el último gran esfuerzo de alcance universal realizado en el siglo recién transcurrido frente al problema de las drogas², y su necesidad resultaba de la ineficacia de los instrumentos existentes a la fecha en que se dictó ya que había "aparecido una nueva forma de criminalidad organizada, que actúa en grupos, bien estructurados, dotados de toda clase de medios materiales y financieros que se dedica al trafico ilegal de drogas, dado los enormes y fáciles beneficios que el narcotráfico produce, y que tiene como objetivo el monopolio de estas en gran escala, y sus pautas de actuación están basadas en la violencia, corrupción y 
amenazas, y su campo de operaciones se extiende más allá de sus fronteras nacionales”. ${ }^{3}$

De ahí que la Convención de Viena de 1988, procura promover, a escala mundial, un marco homogéneo de naturaleza represiva, tipificando las conductas vinculadas con el ciclo del narcotráfico, así como el lavado de activos provenientes de tal actividad, su incautación y/o decomiso. Asimismo, una ágil asistencia y cooperación judicial internacional, el levantamiento del secreto bancario, y otras disposiciones de no menor importancia como el régimen de la entrega vigilada, mecanismos de control respecto de sustancias que se utilizan con frecuencia en la fabricación de estupefacientes o sustancias psicotrópicas, medidas para erradicar el cultivo ilícito de plantas de las que se extraigan estupefacientes, tráfico por el mar, utilización de servicios postales, entre otros.

En lo que tiene que ver con el lavado de activos, el preámbulo de este Convenio Internacional revela las razones de la nueva políitica criminal:

"Conscientes de que el tráfico ilícito genera considerables rendimientos financieros y grandes fortunas que permiten a las organizaciones delictivas transnacionales invadir, contaminar y corromper las estructuras de la administración pública, las actividades comerciales y financieras lícitas y la sociedad en todos sus niveles".

Como ha dicho un autor4, la Convención de Viena "pretende atajar los problemas de las drogas despojando a los narcotraficantes del producto de sus actividades, de manera que se elimine el principal aliciente de sus conductas, es decir, el móvil lucrativo".

De ahí que no resulte extraño entonces que entre los aspectos específicos recomendados a los Estados firmantes para enfrentar el fenómeno derivado de los inmensos recursos generados con los delitos de tráfico de drogas figura el de tipificar en sus respectivas legislaciones, como un delito autónomo, el lavado de activos provenientes del mismo.

El Art. 3.1 b) i) ii), c) i) y iv), de esta Convención, dada la naturaleza internacional del fenómeno y su alcance universal, recoge la forma en que se recomienda a los Estados tipificar el lavado de activos:

b) i) la conversión o la transferencia de bienes a sabiendas de que tales bienes proceden de alguno o algunos de los delitos tipificados o de conformidad con el inciso a) del presente párrafo, o de un acto de participación en tal delito o delitos, con objeto de ocultar o encubrir el origen ilícito de los bienes o de ayudar a cualquier persona que participe en la comisión de tal delito o delitos a eludir las consecuencias jurídicas de sus acciones; 
ii) la ocultación o el encubrimiento de la naturaleza, el origen, la ubicación, el destino, el movimiento o la propiedad reales de bienes, o de derechos relativos a tales bienes, a sabiendas de que proceden de alguno o algunos de los delitos tipificados de conformidad con el inciso a) del presente párrafo o de un acto de participación en tal delito o delitos;

c) i) la adquisición, la posesión o la utilización de bienes, a sabiendas, en el momento de recibirlos, de que tales bienes proceden de alguno o algunos de los delitos tipificados de conformidad con el inciso a) del presente párrafo o de un acto de participación en tal delito 0 delitos;

iv) la participación en la comisión de alguno de los delitos tipificados de conformidad con lo dispuesto en el presente artículo, la asociación y la confabulación para cometerlos, la tentativa de cometerlos y la asistencia, la incitación, la facilitación o el asesoramiento en relación con su comisión.

No obstante que en la doctrina sobre el tema se haya considerado como uno de los mayores aportes de la Convención de Viena de 1988, el establecimiento de esta lista de conductas que deben ser sancionadas para combatir el lavado de activos, hay quien ha considerado "que el precepto trascrito abusa a la hora de enumerar las conductas, recogiendo una larguísima lista de verbos típicos que dificultan la interpretación del mismo".

Esta crítica no es compartida por el penalista uruguayo Miguel Langon Cuñarro, para quien esas disposiciones de la Convención de Viena de 1988 recogen la voluntad de "elaborar un texto aceptable por las distintas culturas y tradiciones, de modo que cada legislador pueda tomar los elementos que sean más acordes con su propio sistema". 5

Como aspecto complementario a la tipificación de las conductas anteriormente descritas la Convención recomienda criterios de proporcionalidad en la aplicación de distintos tipos de sanciones (penas de prisión, sanciones pecuniarias y decomiso) por la comisión de los ilícitos previstos. Esta aplicación debe tomar en cuenta distintas circunstancias que enumera en su Art. 5, que dan particular gravedad a la comisión de la infracción, como son:

"(a) la participación en el delito de un grupo delictivo organizado del que el delincuente forme parte.

(b) la participación del delincuente en otras actividades delictivas internacionales organizadas.

(c) la participación del delincuente en otras actividades ilícitas cuya ejecución se vea facilitada por la comisión del delito.

(d) el recurso a la violencia o el empleo de armas por parte del delincuente.

(e) el hecho de que el delincuente ocupe un cargo público y de que el delito guarde relación con ese cargo. 
la victimización o utilización de menores de edad.

(g) el hecho de que el delito se haya cometido en establecimientos penitenciarios, en una institución educativa $o$ en un centro asistencial o en sus inmediaciones o en otros lugares a los que escolares y estudiantes acudan para realizar actividades educativas, deportivas y sociales.

(h) una declaración de culpabilidad anterior, en particular por delitos análogos, por tribunales extranjeros o del propio país, en la medida en que el derecho interno de cada una de las Partes lo permita".

Por otra parte, la Convención de Viena de 1988 se preocupa del tema probatorio en los delitos que prevé en el Art. 5.7, por lo que recomienda a los Estados la inversión de la carga de la prueba en la medida en que esto sea compatible con el régimen constitucional de cada Estado6, al mismo tiempo que dispone en el Art. 3.3 que "el conocimiento, la intención o la finalidad requeridos como elementos de los delitos enunciados en el párrafo 1 del presente artículo podrá inferirse de las circunstancias objetivas del caso".

En consonancia con la finalidad de la nueva política criminal frente al problema de las drogas, esta Convención hace énfasis en lo atinente a las medidas de incautación y decomiso de todos aquellos bienes que son el producto o tengan su origen en los delitos de tráfico de drogas, sin perjuicio de los derechos de los terceros de buena fé7.

Finalmente, la Convención de Viena de 1988, se preocupa por trazar disposiciones que la hagan eficaz, sobre todo, debido a la naturaleza internacional del fenómeno del narcotráfico. En ese sentido, impulsa un régimen de asistencia judicial8 entre los Estados que ponen énfasis en hacer posible la actividad probatoria en aspectos claves para la persecución eficaz de estas infracciones, tales como lo atinente al tema probatorio, en el que se levanta incluso el secreto bancario, y el facilitar la ubicación de los bienes sujetos a incautación o decomiso sin importar donde se encuentren. En este último aspecto, y con la finalidad de estimular la cooperación y asistencia judicial internacional, la Convención abre la posibilidad de repartirse ${ }^{9}$ el producto, los bienes o fondos derivados de los mismos, entre el Estado requeriente y el Estado requerido, es decir, el que presta la asistencia judicial internacional.

La Convención de las Naciones Unidas contra el Tráfico llícito de Estupefacientes y Sustancias Psicotrópicas constituye, sin lugar a dudas, una norma bastante completa, desde el punto de vista de su contenido. A pesar de estar limitada a un tema específico, ha constituido el primer paso de importancia universal para enfrentar en la aldea global el crimen organizado. "Este documento de las Naciones Unidas marca el inicio de la difusión internacional de los tipos penales sobre blanqueo de dinero y sus normas consagran el prototipo de un injusto internacional de blanqueo cuyo modelo imitarán varias legislaciones"10, entre ellas la nuestra. 


\subsubsection{Convención de Palermo de 2000}

Su denominación completa es "Convención de las Naciones Unidas contra la Delincuencia Organizada Transnacional". Fue aprobada por la Asamblea General de las Naciones Unidas y abierta a la firma de los Estados, entre el 12-15 de diciembre del año 2000, en Palermo, Italia. Entró en vigencia el 29 de septiembre del año 2003. La República Dominicana suscribió dicha Convención, pero aún el Congreso Nacional de la República no la ha ratificado.

Esta Convención tiene 41 artículos, además de tres protocolos complementarios que permiten hacer frente a manifestaciones específicas de la delincuencia organizada transnacional: para prevenir, reprimir y sancionar la trata de personas y el tráfico ilícito de emigrantes por tierra, mar y aire y contra la fabricación y el tráfico ilícitos de armas de fuego, sus piezas y componentes y municiones.

La Convención de Palermo del 2000 se ha considerado como la continuación de la Convención de Viena de 1988, por el interés cada vez más insistente por parte de las Naciones Unidas de trascender más allá de la frontera del narcotráfico y ampliar el límite de aplicación de la ley penal a una criminalidad renovada y a una red de delincuencia transnacional organizada cada vez más amplia.

La Convención de Viena de 1988 pretende el castigo de una serie de delitos relacionados con el tráfico de drogas, incluyendo la penalización del lavado de activos. La Convención de Palermo tiene un alcance más profundo al tipificar como delito la participación de un individuo en un grupo delictivo organizado'1 distinto del intento o consumación de una actividad delictiva, así como la utilización del sistema financiero o instituciones financieras no bancarias para el lavado de activos. Asimismo, penaliza la corrupción 12 de un funcionario público que mediante la promesa, el ofrecimiento o la concesión de un beneficio indebido que actúe o se abstiene de actuar en cumplimiento de sus funciones oficiales y obstruye la justicia mediante el uso de la fuerza física, amenazas o intimidación, o la promesa, el ofrecimiento o concesión de un beneficio indebido para inducir a un falso testimonio u obstaculizar la prestación de testimonio o la aportación de pruebas en un proceso en la comisión de un delito.

Respecto a la penalización del lavado del producto del delito ${ }^{13}$ se mantiene en líneas generales lo establecido en la Convención de Viena sobre la aplicación de las medidas legislativas que sean necesarias para tipificar como delito, cuando se cometan intencionalmente; la conversión o transferencia de bienes con el propósito de ocultar o disimular la verdadera naturaleza, origen, ubicación, disposición, movimiento o propiedad de bienes, al igual que la adquisición, posesión o utilización de los mismos a sabiendas del origen ilícito de dichos bienes.

Asimismo, se incluye la asociación y la confabulación para cometerlos, el intento de cometerlos, y la ayuda, la incitación, la facilitación y el asesoramiento en aras de su comisión, haciéndolo extensivo a los "delitos graves", entendiendo por tales a todos aquellos sancionables con una privación de libertad máxima de al menos cuatro 
años o con una pena más grave.

Recomienda la Convención de Palermo a los Estados ampliar de manera significativa la tipificación del lavado de activos para que involucre una gama más amplia de delitos previos, la cooperación e intercambio de información a escala nacional e internacional conforme al Derecho interno de cada país y establecer una Unidad de Inteligencia Financiera para la recopilación de información sobre posibles actividades de lavado de capitales ${ }^{14}$.

A diferencia de la Convención de Viena de 1988, esta Convención otorga especial relevancia a los mecanismos de prevención del lavado de activos, disponiendo en su Art. 7.1, a), lo siguiente:

"Cada Estado Parte: Establecerá un amplio régimen interno de reglamentación y supervisión de los bancos y las instituciones financieras no bancarias y, cuando proceda, de otros órganos situados dentro de su jurisdicción que sean particularmente susceptibles de utilizarse para el blanqueo de dinero, y en este régimen se hará hincapié en los requisitos relativos a la identificación del cliente, el establecimiento de registros y la denuncia de las transacciones sospechosas".

\subsubsection{Convención de las Naciones Unidas contra la Corrupción}

La Convención de las Naciones Unidas contra la Corrupción constituye el último instrumento de alcance universal auspiciado por ese organismo. Quedó abierta a la firma de los Estados del 9 al 11 de diciembre del 2003, en la ciudad de Mérida, México. La República Dominicana fue uno de los Estados firmantes. Entraría en vigor el "nonagésimo día después de la fecha que se haya depositado el trigésimo instrumento de ratificación". ${ }^{15}$

Se trata de un instrumento extraordinariamente completo, en función de su contenido. Consta de 71 artículos, la mayor parte de ellos, bastante extensos y muchos, sobre todo los que tocan los aspectos relativos a la incautación y decomiso de bienes ${ }^{16}$, en especial a través de la asistencia y cooperación judicial internacional17, guardan parecidos términos con los utilizados por las Convenciones de Viena de 1988 y de Palermo del año 2000.

En su preámbulo destaca la preocupación "por los vínculos entre la corrupción y otras formas de delincuencia, en particular la delincuencia organizada y la delincuencia económica, incluido el blanqueo de dinero".

Es por ello que el tema del lavado de activos no resulte ajeno al contenido de esta Convención en líneas parecidas a la forma contemplada en la Convención de Palermo, ya que contiene previsiones desde el punto de vista represivo y preventivo.

El Art. 14 de la Convención se titula "Medidas para prevenir el blanqueo de dinero", y hace hincapié en la 
importancia de que las entidades financieras o no, susceptibles de ser utilizadas en el lavado de activos, en este caso provenientes de actos de corrupción, cuenten con políticas relativas a la identificación del cliente, al establecimiento de registros y al reporte de transacciones financieras sospechosas, insistiendo, además, al igual que la Convención de Palermo, en el establecimiento de Unidades de Análisis o Inteligencia Financiera que recopile, analice y difunda información sobre posibles actividades de lavado de activos.

El Art. 23 de la Convención, por su parte, recomienda tipificar el lavado de activos producto del delito, cometido intencionalmente, en las mismas formas típicas previstas en la Convención de Palermo. Igual similitud encontramos entre ambas convenciones en lo que tiene que ver con la previsión en el artículo 6.2, letra e), de la Convención contra la Corrupción donde prescribe que las legislaciones internas de los países adherentes podrán disponer que los delitos de lavado de activos no se aplicarán a la persona que haya cometido el delito determinante.

\subsection{Tratados regionales en el ámbito europeo}

\subsubsection{Convenio de Estrasburgo}

En fecha 8 de Noviembre de 1990 fue abierta a la firma, en la ciudad de Estrasburgo, el Tratado denominado "Convenio relativo al blanqueo, identificación, embargo y confiscación de los productos del delito". Es conocido también como el Convenio de Estrasburgo. Previamente había sido aprobado por el Comité de Ministros del Consejo de Europa, en septiembre del 1990.

Este instrumento, aunque se ha quedado limitado por su origen al ámbito europeo, está concebido de forma abierta. Como afirma un autor, "de hecho observadores de Australia, Canadá y los EE.UU. estuvieron presentes en el Comité restringido de expertos y participaron activamente en la redacción del texto. Por lo tanto, no se trata en modo alguno de un Convenio sólo para los países europeos sino que nos hallamos ante una de las denominadas "Convenciones abiertas" a la que en principio están llamados, al tenor del artículo 36.1 del Convenio, los tres estados no miembros del Consejo que participaron en la elaboración del Convenio, pero al que también pueden ser invitados países ajenos al Consejo..., aunque esto requiere un procedimiento especial". 18

Entre los objetivos de esta Convención figura la de establecer medidas eficaces para combatir las infracciones graves, así como privar a los delincuentes del uso y disfrute de sus ganancias. Es decir, que desde este punto de vista se adhiere a la filosofía de la Convención de Viena de 198819, pero obviamente se separa porque no se limita al lavado de activos proveniente del narcotráfico sino que amplía este concepto a rendimientos ilegales provenientes de cualquier delito grave20. 
El Convenio de Estrasburgo es considerado como un instrumento internacional bastante completo, por la diversidad de su contenido, ya que prevé un conjunto de normas que comprende la tipificación penal, el procedimiento, desde la investigación hasta la imposición y ejecución de una sentencia de confiscación, así como los aspectos procesales de la cooperación internacional en materia de lavado de activos. Su estructura consta de un breve preámbulo y cuatro capítulos de los que el primero define los términos producto, instrumentos, confiscación y delito principal; el segundo acoge las medidas legislativas que se deben adoptar en cada país, entre las que destaca el embargo y comiso, pero sobre todo la obligación de incriminar el lavado de activos en la forma amplia concebida en este instrumento internacional; un extenso capítulo tercero trata sobre la cooperación internacional en materia de identificación, embargo y decomiso, y concluye el Convenio con un cuarto capítulo relativo a disposiciones finales.

Es importante resaltar dentro del contenido del Convenio las recomendaciones para el establecimiento de técnicas indagatorias especiales, dadas la complejidad y naturaleza del fenómeno del lavado de activos, entre éstas, las órdenes de seguimiento, vigilancia, intervención de las telecomunicaciones, acceso a sistemas informáticos, y órdenes de presentación de documentos.

Como novedades adicionales a la ampliación del delito previo, ya citada, el Convenio de Estrasburgo introduce igualmente dos aspectos de suma importancia21: uno, el relativo al principio de universalidad, y el otro el atinente al privilegio del autoencubrimiento.

En cuanto al principio de universalidad, este Convenio lo consagra al disponer que "será irrelevante que el delito principal quede sometido a la jurisdicción penal de la Parte". Es decir, que resulta indiferente el lugar de comisión del delito base.

Finalmente, en cuanto al privilegio de autoencubrimiento, el Convenio concede a los Estados Partes la facultad de no aplicar el lavado de activos a los que intervengan en el hecho previo, es decir, que tendrán plena libertad para decidir la punibilidad acumulativa. Sobre este aspecto la Convención de Viena de 1988 guardó absoluto silencio. No obstante, la Convención de Palermo22 y la reciente Convención de Naciones Unidas contra la Corrupción23 recogen un precepto semejante al del Convenio de Estrasburgo.

\subsubsection{Directiva de las Comunidades Europeas de 1991}

La Directiva, del 10 de junio de 1991, de la Comunidad Europea sobre lavado de activos tuvo su origen en la intención del gobierno de los Estados Unidos de Norteamérica de extender a las entidades financieras extranjeras que operaban en su territorio, la obligatoriedad de reportar a las autoridades las transacciones en dólares por sumas mayores de US\$10.000, so pena de cancelarles la licencia para operar en los Estados 
Unidos y sus territorios.

Esta Directiva del Consejo de las Comunidades Europeas estuvo encaminada a prevenir la utilización del sistema financiero para blanquear los bienes procedentes de actividades delictivas, ya que esto pone en serio peligro la estabilidad y solidez de los establecimientos de crédito, y del sistema financiero en general ante una eventual pérdida de confianza del público, siguiendo fundamentalmente las 40 Recomendaciones del Grupo de Acción Financiera (GAFI).

La definición de lavado de capitales de la Directiva está inspirada fundamentalmente en la Convención de Viena de 1988 y en el Convenio de Estrasburgo y prevé la tipificación de este delito cuando intencionalmente se produzcan acciones tendientes a convertir, transferir, ocultar o encubrir la verdadera naturaleza, origen, localización, disposición o movimiento de la propiedad de bienes o sus derechos, a sabiendas de que dichos bienes provienen de una actividad ilícita o de una participación en ese tipo de actividad24.

También se considera lavado de activos la participación en algunas de las acciones mencionadas anteriormente, la asociación para delinquir, las tentativas de llevarlas a cabo, el ayudar, instigar o aconsejar a alguien para realizarlas o el hecho de facilitar su ejecución, independientemente de que hayan sido generados en territorio de otro Estado miembro o en el de un tercer país. En este último punto coincide con la prevista en el Convenio de Estrasburgo.

La Directiva es una norma de carácter fundamentalmente preventiva y se limita a señalar que los Estados Miembros velarán para que el lavado de activos quede prohibido, sin concretar cual debería ser el carácter penal, administrativo, civil, etc., de esta inobservancia.

Esta Directiva impone la obligación de aprobar una legislación interna de carácter administrativo que contribuya a evitar, restringir o vigilar ciertas actividades susceptibles de ser utilizadas para lavar activos, tales como el manejo, transferencia o depósitos de grandes cantidades en efectivo y el adecuado conocimiento del cliente. No es claro en cuanto a las sanciones de carácter penal.

Otros aspectos importantes de esta Directiva tienen que ver con las obligaciones de prevención que deben observar las instituciones financieras, que deberán exigir a sus clientes plena identificación ${ }^{25}$ para la apertura de cuentas corrientes o de ahorros o cuando existan dudas de que sus clientes no actúan por cuenta propia26, y conservar documentos de transacciones. Asimismo, tienen el deber de colaboración con las autoridades 27 y de abstención de realizar operaciones cuando exista sospecha de lavado de activos 28 .

\subsubsection{Directiva del Parlamento y del Consejo de la Unión Europea}

Esta Directiva ha sido numerada como 2001/97/CE, y modifica la Directiva de 1991, relativa a la prevención de la utilización del sistema financiero para el lavado de activos. 
Con ella la Unión Europea fortalece los dispositivos establecidos en la Directiva de 1991, al obligar a los países miembros a implementar las medidas necesarias para combatir este delito antes del 15 de junio de 2003, que deberán ampliar el cuadro de infracciones previas que generan los recursos envueltos en el proceso de lavado de activos a todo tipo de delitos graves, así como el ámbito de los sujetos obligados.

Para garantizar una mayor cobertura del sector financiero la Directiva 2001 es aplicable en adelante no solo a las instituciones financieras y a las entidades de crédito que tengan su sede social dentro o fuera de la comunidad, sino también a las agencias de cambio, empresas de transferencia o envío de dinero, agencias de seguros y, en general, a toda empresa de inversión que negocie sus participaciones y acciones.

En cuanto a los sujetos obligados 29 se incluye adicionalmente a las personas naturales o jurídicas que actúen en el ejercicio de su profesión, tales como: auditores, contadores y asesores fiscales, agentes de propiedad raíz, notarios, abogados, personas que comercian con artículos de valor elevado, como metales y piedras preciosas, objetos de arte, subastadores, cuando el pago realizada sea superior a 15.000 euros.

\subsection{Tratados regionales en el ámbito americano}

\subsubsection{Convención Interamericana contra la Corrupción}

La Convención Interamericana contra la Corrupción fue suscrita en Caracas, Venezuela, el 29 de marzo de 1996, bajo los auspicios de la Organización de Estados Americanos (OEA).

La República Dominicana, mediante la Resolución No. 489-98, ratificó dicha Convención, siendo promulgada por el Poder Ejecutivo en fecha 20 del mes de noviembre del año 1998, por lo que forma parte de nuestro ordenamiento jurídico.

Aunque se trata de una Convención especializada en el tema de la corrupción administrativa, el tema del lavado de activos figura entre sus preocupaciones esenciales debido a "los vínculos cada vez más estrechos entre la corrupción y los ingresos provenientes del tráfico ilícito de estupefacientes, que socavan y atentan contra las actividades comerciales, y financieras legítimas y la sociedad, en todos los niveles $30^{\prime \prime}$.

De ahí que en el Art. VI. 1., letra d), la Convención recomienda a los Estados sancionar "el aprovechamiento doloso u ocultación de bienes provenientes de actos de corrupción", lo que obliga a nuestro País a sancionar el lavado de activos provenientes de conductas de corrupción administrativa.

\subsubsection{Convenio Centroamericano para la Prevención y la Represión de los Delitos de Lavado de}




\section{Dinero y Activos relacionados con el Tráfico llícito de Drogas y Delitos Conexos}

Este convenio tiene una naturaleza regional limitada originalmente a los siguientes países centroamericanos: Costa Rica, El Salvador, Guatemala, Nicaragua, y Panamá. Fue suscrito en este último país, el 11 de julio de 1997. La República Dominicana se adhirió a este Convenio, en fecha 6 de noviembre del mismo año, y el Congreso Nacional lo ratificó posteriormente.

El contenido de este convenio es prácticamente exacto al Reglamento Modelo elaborado por los expertos del Comité de Lavado de Activos de la Comisión Interamericana para el Control del Abuso de Drogas (CICAD), órgano de la Organización de Estados Americanos, en la versión vigente a la fecha en que se suscribió, que limitaba el lavado de activos a los recursos provenientes del tráfico de drogas, versión que fue abandonada posteriormente conforme se indicará más adelante cuando se trate lo relativo a las propuestas normativas.

\subsubsection{Convención Interamericana contra el Terrorismo}

Esta Convención fue aprobada mediante la Resolución 1840 de la Asamblea General de la Organización de Estados Americanos, efectuada en Trinidad y Tobago, en fecha 3 de junio del año 2002. La República Dominicana la firmó, pero aún está pendiente del trámite constitucional de ratificación por ante el Congreso Nacional.

Esta Convención en su artículo 6 señala que cada "Estado Parte tomará las medidas necesarias para asegurar que su legislación penal referida al delito del lavado de dinero incluya como delitos determinantes del lavado de dinero" los delitos de terrorismo31, establecidos en los instrumentos internacionales que describe32.

La Convención Interamericana contra el Terrorismo obliga a los Estados Partes a establecer un régimen jurídico y administrativo para prevenir la financiación del terrorismo, en especial un régimen interno normativo y de supervisión para los bancos, instituciones financieras y otras actividades consideradas particularmente susceptibles de ser utilizadas para financiar actividades terroristas, reiterando el cumplimiento de obligaciones de prevención tradicionalmente previstas en los esfuerzos frente al lavado de activos, como la identificación de clientes, el registro de documento y la comunicación de transacciones financieras sospechosas o inusuales 33.

Asimismo, pone énfasis en obligar a los Estados a establecer "medidas de detección y vigilancia de movimientos transfronterizos de dinero en efectivo e instrumentos negociables al portador" 34 , a compartir e intercambiar información a través de Unidades de Inteligencia Financiera35, y, en sentido general, recomienda aplicar las recomendaciones del GAFI, GAFIC, CICAD y GAFISUD36. 


\section{Declaraciones y Recomendaciones de alcance universal}

\subsection{Declaraciones y Recomendaciones de alcance universal}

\subsubsection{Declaración de Principios de Basilea}

Esta Declaración se denominó "Declaración de Principios de Basilea sobre Prevención de la Utilización del Sistema Bancario para el Blanqueo de Fondos de Origen Criminal". Esta declaración antecedió a la apertura de firmas de la Convención de Viena de 1988, y que fue emitida el día 12 de diciembre de 1988.

Esta Declaración emanó del denominado "Grupo de los Diez", conformado por representantes de los Bancos Centrales de Alemania, Bélgica, Canadá, Estados Unidos, Francia, Holanda, Italia, Japón, Reino Unido, Suecia y Suiza. Se adicionó al grupo Luxemburgo.

Desde el punto de vista de su contenido, esta Declaración de Principios tiene cinco (5) puntos fundamentales. Un primero, dedicado al objetivo que perseguía la declaración; el segundo, a la identificación de los clientes; el tercero, al acatamiento de las leyes; el cuarto, a la cooperación con las autoridades y el quinto, a la adhesión a la declaración de principios.

En cuanto al primer aspecto, lo que persigue la declaración es trazar algunas políticas y procedimientos que deben cumplir las instituciones bancarias a fin de contribuir a la represión del lavado de activos por conducto del sistema bancario nacional e internacional. En especial, alentar la vigilancia contra el uso delictivo del sistema de pagos. Ello así, porque los bancos y otras instituciones financieras, por la naturaleza de sus actividades, pueden ser utilizados sin su consentimiento para la transferencia o depósito de dinero proveniente de actividades delictivas.

La regla de identificación de clientes, tan extendida hoy día, encuentra su origen en esta Declaración de Principios de Basilea, que precisa que se "debe tener especial cuidado en identificar la propiedad de cada una de las cuentas y de todos los servicios de caja de seguridad".

Por otra parte, la Declaración de Principios de Basilea sienta las bases para la profesionalización de la actividad bancaria, al señalar el alcance del acatamiento de las leyes, obligando a las mismas a conocer a sus clientes como el mecanismo esencial, de naturaleza preventiva, que le permita evitar realizar operaciones relacionadas con actividades de lavado de activos.

Asimismo, se incentiva la cooperación con las autoridades y se insta al trazado de políticas preventivas por parte de los órganos superiores de las entidades bancarias y financieras, que incluya talleres de capacitación 
sobre esas políticas al personal, la conservación del rastro documental de las transacciones y el establecimiento de procedimientos de auditoria interno que vigilen el cumplimiento de estos aspectos.

\subsubsection{Declaración de Propósitos del Grupo Egmont (1997)}

En fecha 9 de junio de 1995 se constituyó de manera formal el Grupo Egmont de Unidades de Inteligencia Financiera de distintos países. Su nombre se debe a que la reunión en que se conformó este grupo de trabajo fue efectuada en el Palacio Egmont-Aremberg de Bruselas37.

Este grupo de trabajo, que en la actualidad cuenta con más de sesenta (60) Unidades de Inteligencia Financiera de distintos países del mundo, continuó sus reuniones en París38; San Francisco, California39; Roma40; y en Madrid41. Otras reuniones periódicas del grupo ya se han realizado42.

En la reunión de Madrid se emitió una Declaración de Propósitos, que confirmó la definición de lo que es una Unidad de Inteligencia Financiera43, adoptada en la asamblea general efectuada en Roma, y se convino como prioridad la creación de estas Unidades en todo el mundo, el estímulo del intercambio de información por vía de reciprocidad y acuerdo mutuo, el acceso a un sitio Web seguro del Grupo Egmont para todas las Unidades, la elaboración de modalidades apropiadas de intercambio de información, entre otros aspectos de importancia.

\subsubsection{Declaración Políitica y Plan de Acción contra el Lavado de Activos de la ONU (1998)}

Esta declaración y plan de acción fue adoptada durante la vigésima sesión extraordinaria de la Asamblea General de las Naciones Unidas para hacer frente al problema de las drogas en el mundo, efectuada en la ciudad de Nueva York, el 10 de junio de 1988.

En la misma los Estados Miembros de las Naciones Unidas se comprometen a luchar con una energía particular frente al lavado de activos provenientes del narcotráfico, y de otras infracciones graves, al considerar que puede afectar la integridad, la confianza y la estabilidad de los sistemas financieros y comerciales, así como las estructuras gubernamentales del mundo entero.

Un dato importante de esta Declaración y Plan de Acción es que otorga primordial importancia a la aplicación de determinadas medidas que deben figurar en los marcos jurídicos de los distintos países, tales como la identificación, el embargo y la confiscación del producto del crimen, la incorporación del crimen del lavado de activos en los acuerdos de investigaciones judiciales entre Estados, así como también los aspectos preventivos, principalmente la aplicación por los sujetos obligados de la regla "conozca al cliente", la obligación de conservar documentos de transacciones financieras, y reportar transacciones sospechosas, entre otros 
aspectos.

\subsubsection{Las 40 Recomendaciones del GAFI}

Un paso de fundamental importancia en los esfuerzos mundiales para enfrentar el lavado de activos lo constituyó la conformación del Grupo de Acción Financiera (GAFI), conformado por los representantes de los siete países más industrializados del mundo (Estados Unidos, Japón, Alemania, Francia, Reino Unido, Italia y Canadá) y el Presidente de la Comisión de las Comunidades Europeas, dada su preocupación por las asoladoras proporciones que el problema de la droga había alcanzado. Muy pronto esa preocupación se extendió a otras formas delictivas vinculadas con delitos diferentes al tráfico de drogas.

Este grupo de trabajo fue integrado por el G-7, durante una Conferencia efectuada en París el 16 de julio de 1989, que emitió posteriormente las famosas 40 Recomendaciones 44 , y, más recientemente, las 8 Recomendaciones ${ }^{45}$ especiales sobre la financiación del terrorismo 46.

Las 40 Recomendaciones, revisadas en 1996, son de un contenido diverso y han jugado un rol primordial en las normas legales sobre lavado de activos en los distintos países del mundo.

Entre otros aspectos hace énfasis en el papel de los sistemas legales nacionales en el combate contra el lavado, ampliando el concepto de este delito al producto de otras actividades ilegales graves 47 , así como sugiriendo el establecimiento de medidas cautelares y decomiso de bienes.

Resaltan, además, el papel del sistema financiero en el combate contra el lavado recomendando la adopción de una serie de medidas con ocasión de la utilización de los servicios que ofrecen, tales como la identificación de clientes, el registro por un período determinado de la documentación que sustentan sus transacciones, así como el reporte a las autoridades de las transacciones sospechosas, es decir, aquellas que efectuadas por el público resulten complejas, insólitas, significativas o sin fundamento económico o legal visible.

Recomienda asimismo el Grupo de Acción Financiera (GAFI), en sus cuarenta recomendaciones el levantamiento del secreto bancario, así como la exención de responsabilidad civil, penal y administrativa a los empleados y funcionarios de banca cuando comuniquen de buena fé a las autoridades las transacciones sospechosas 48 .

Asimismo, dicho grupo considera necesario para la aplicación de una política de prevención del lavado de capitales en las instituciones financieras, el desarrollo de programas permanentes de capacitación de personal así como el establecimiento de políticas internas, procedimientos y controles orientados específicamente a evitar la utilización de este tipo de instituciones por quienes se dedican a la actividad del lavado de capitales 49 . 
Señala el papel de los reguladores bancarios en la vigilancia para el cumplimiento de las medidas de prevención por las instituciones financieras 50.

Finalmente, un aspecto importante que contienen estas 40 Recomendaciones del GAFI es lo relativo a las personas expuestas políticamente, en relación a los cuales las instituciones financieras, además de los procedimientos de debida diligencia, deben contar con "sistemas de gestión de riesgos apropiados para determinar si el cliente e una persona políticamente expuesta; obtener la aprobación de los directivos de mayor jerarquía para establecer relaciones comerciales con esos clientes; tomar mediadas razonables para determinar cual es el origen de la riqueza y el origen de los fondos y llevar a cabo una vigilancia permanente más exhaustiva de la relación comercia|51".

\subsubsection{Las 8 Recomendaciones Especiales sobre la Financiación del Terrorismo}

Los terribles acontecimientos acaecidos en las ciudades de Nueva York y Washington, el 11 de septiembre del 2001, y las investigaciones llevadas a cabo sobre dicho hecho motivaron que el Grupo de Acción Financiera (GAFI) estableciera un marco básico para prevenir y suprimir la financiación del terrorismo y de los actos terroristas.

Por ello emitieron, en una reunión efectuada en la ciudad de Washington, Capital de los Estados Unidos de Norteamérica, el 30 de octubre del 2001, las ocho (8) recomendaciones especiales sobre la financiación del terrorismo, cuyos títulos son: (I) Ratificación y ejecución de los instrumentos de las Naciones Unidas; (II) Tipificación de la financiación del terrorismo y el blanqueo asociado; (III) Congelamiento y decomiso de activos terroristas; (IV) Informe de transacciones sospechosas relativas al terrorismo; (V) Cooperación internacional; (VI) Sistemas alternativos de envíos de fondos; (VII) Transferencias por cable; y (VIII) Organizaciones sin fines de lucro.

\subsubsection{Principios de Wolsgferb}

Se denominan Principios de Wolsgferb porque fue en esa localidad de Suiza donde, bajo la colaboración de la organización Transparencia Internacional, se reunieron representantes de los bancos privados internacionales ABN AMOR Bank N.V., Barclays Bank, Banco Santander Central Hispano, S.A., Chase Manhattan Corporation, Citibank, N.A, Credit Suisse Group, Deutsche Bank AG, HSBC, J.P. Morgan, Inc., Societé Generale, UBS AG, y emitieron, en fecha 30 de octubre del año 2000, once (11) principios que procuran una guía global para una sana conducta de negocios en la banca privada internacional.

Estos importantes principios tratan los siguientes aspectos: (1) Aceptación de clientes: Lineamientos generales; 
(2) Aceptación de clientes: Situaciones que requieren informes o atención adicionales; (3) Actualización de archivos de clientes; (4) Prácticas para identificar actividades inusuales o sospechosas; (5) Monitoreo; (6) Responsabilidad de control; (7) Informes; (8) Educación, capacitación e información; (9) Requisitos para la retención bajo registro; (10) Excepciones y desvíos; y (11) Organización contra el lavado de dinero.

Estos principios fueron revisados en mayo del año 2002.

Asimismo, el mismo grupo de la banca internacional propició un conjunto de principios relativos a la "supresión del financiamiento del terrorismo", que consta de siete (7) puntos fundamentales.

\subsection{Declaraciones y Recomendaciones en el ámbito europeo}

\subsubsection{Recomendación del Consejo de Europa}

Tiene una especial importancia, ya que constituyó la primera iniciativa internacional sobre el lavado de activos, en una época en que aún esta actividad no constituía un tipo penal especial

Esta Recomendación fue adoptada por el Comité de Ministros del Consejo de Europa, en fecha 26 de junio de 1980, y se denominó como la "Recomendación No. R (80) 10 relativa a medidas contra la transferencia y el encubrimiento de capitales de origen criminal".

Su antecedente lo encontramos en la vigésima sexta sesión plenaria efectuada en 1977, efectuada por el Comité Europeo para los problemas criminales, que tenía un mandato específico de estudiar la problemática concerniente a la transferencia ilícita de capitales de origen delictivo. El informe de este Comité sirvió de sustento para la Recomendación del Consejo de Europa de 1980.

Esta Recomendación tuvo la visión de considerar que el problema del reciclaje de fondos provenientes de actividades delictivas necesitaba de "una política global en la que el sistema bancario va a desempeñar un papel tanto preventivo como represivo, en la medida en que colabore con las autoridades competentes". 52 No obstante no contiene ninguna disposición de carácter penal, ya que se limita a establecer un estándar mínimo de medidas bancarias para combatir dicho fenómeno y, mucho menos, por estar dirigida al sector bancario, no contempla la amplia gama de actividades y profesiones susceptibles de ser utilizadas en el lavado de activos proveniente de actividades delictivas.

Su contenido no es extenso. Se limita a aspectos muy específicos. Uno la importancia de la verificación de la identidad de los clientes, a través de documentos oficiales, con motivo de la apertura de una cuenta o la 
constitución de un depósito, el alquiler de cajas de seguridad y operaciones de contado y transferencias interbancarias en cantidades de cierta importancia, tomando en cuenta la posibilidad de fraccionamiento; así como una formación del personal bancario de ventanilla en lo referente al control de documentos de identidad. Otro, la necesidad de una cooperación, nacional e internacional entre los establecimientos bancarios, con la ayuda de INTERPOL, para intercambiar informaciones relativas a la circulación de billetes de banco utilizados con ocasión de actos delictivos.

\subsection{Declaraciones y Recomendaciones en el ámbito americano}

\subsubsection{Declaración de Ixtapa}

El 20 de abril de 1990 se produjo en el Continente Americano, bajo los auspicios de la Organización de Estados Americanos (OEA), la denominada "Declaración y Programa de Acción de Ixtapa", en seguimiento de la "Alianza de las Américas contra el Narcotráfico".

Entre las motivaciones de dicha Declaración figura la preocupación de que "los enormes beneficios financieros y las riquezas derivadas del tráfico ilícito de drogas y de las actividades criminales conexas posibilitan que las asociaciones delictivas trasnacionales penetren en las estructuras de los gobiernos, las actividades comerciales legítimas y la sociedad en todos los niveles, y las contaminen y corrompan, iniciando así el desarrollo económico y social, distorsionando los procedimientos jurídicos y socavando las bases de los Estados".

Como resultado concreto de esta Declaración se resalta la recomendación a la Asamblea General de la Organización de Estados Americanos (OEA) para que la Comisión Interamericana para el Control del Abuso de Drogas (CICAD) integre un grupo interamericano de expertos que elabore un reglamento modelo sobre lavado de activos, que fue concluido en su primera versión en el año 1992.

\subsubsection{Las 19 Recomendaciones del GAFIC}

Asimismo, en el ámbito caribeño el Grupo de Acción Financiera del Caribe (GAFIC), durante una Conferencia sobre Blanqueo de Capitales efectuada en junio de 1990 y posteriormente con motivo de una Asamblea Ministerial acerca del mismo tema efectuada en Kingston, Jamaica, en noviembre de 1992, emitió 19 recomendaciones relativas a la represión, prevención y detección de operaciones de lavado de capitales.

El contenido de las 19 Recomendaciones del GAFIC es diverso al incluir aspectos penales, preventivos y administrativos. Se destaca el énfasis del GAFIC en sus recomendaciones para que los Estados que lo integran incorporen en sus legislaciones las 40 Recomendaciones del GAFI, así como la ratificación de la Convención 
de Viena de 1988.

\subsubsection{Declaración de Kingston}

Esta declaración se produjo en el marco de una reunión Ministerial llevada a efecto en Jamaica, en noviembre de 1992. Los países participantes, en la Declaración de Kingston sobre Lavado de Dinero, se comprometieron a ratificar la Convención de Viena de 1988; a incorporar el reglamento Modelo de la CICAD-OEA para el Lavado de Dinero como parte de sus leyes domésticas, y a aplicar las 40 Recomendaciones del GAFI y las 19 Recomendaciones establecidas en Araba por el GAFIC.

Se creó una Secretaría de carácter institucional para controlar el progreso de la aplicación de la Declaración y a su vez coordinar y evaluar las legislaciones de los países miembros, proporcionar formación y asistencia técnica y funcionar como centro de coordinación entre el GAFIC y terceros países y organismos internacionales en materia de lucha contra el lavado de dinero.

\subsubsection{Declaración Ministerial de Buenos Aires}

En diciembre de 1994 se efectuó en Miami, Florida, Estados Unidos de Norteamérica, la llamada "Cumbre de las Américas". En ella 34 Jefes de Estado del Hemisferio, incluyendo el anfitrión, el Presidente de los Estados Unidos, discutieron temas sociales, políticos y económicos de interés común, entre ellos, el relativo al tráfico de drogas y el lavado de activos.

Entre los puntos acordados en dicha Cumbre figuró la realización de una Conferencia Ministerial sobre Lavado de Activos en la que se buscara un consenso para poner en práctica medidas que permitieran enfrentar eficazmente esta ilícita actividad.

Dicha Conferencia se produjo en la ciudad de Buenos Aires, Argentina, emitiendo un Comunicado Ministerial de fecha 2 de diciembre del 1995, contentivo de seis (6) puntos fundamentales: (a) Declaración de Principios; (b) Plan de Acción; (c) Acciones Jurídicas; (d) Acciones Reguladoras; (e) Medidas de Aplicación de las Leyes; y (f) Evaluación del Progreso.

Como aspectos específicos contenidos en este Comunicado Ministerial figura la recomendación de extender la tipificación del lavado de activos cuando los recursos envueltos provengan de delitos graves, con lo que se abandona la vinculación exclusiva con el tráfico de drogas; la implementación del Reglamento Modelo elaborado por los expertos de la CICAD, así como la implementación de las 40 recomendaciones del GAFI y las 19 recomendaciones del GAFIC; la de establecer en las respectivas legislaciones internas los mecanismos legales que permitan privar a los delincuentes del uso y disfrute de los bienes y recursos que tienen su origen 
en actividades delictivas, recomendando a tales fines hacer uso de la cooperación y asistencia judicial internacional.

Asimismo, el Plan de Acción trazado en este Comunicado Ministerial insta a los Estados Partes a facilitar el intercambio de pruebas e información con motivo de las investigaciones y enjuiciamientos de lavado de activos; implementar acuerdos bilaterales o multilaterales que permitan el reparto equitativo de los bienes que hayan sido decomisados entre los Estados que participen en la investigación; y promulgar leyes que permitan el uso de técnicas de investigación que faciliten la investigación del lavado de activos, tales como operaciones encubiertas, y vigilancia electrónica con autorización judicial.

Este Comunicado Ministerial, dentro de su línea de acción, se preocupa también por el régimen de prevención aplicable a las instituciones financieras, así como a otras empresas susceptibles de ser utilizadas en el lavado de activos, haciendo hincapié en la importancia del reporte de transacciones financieras sospechosas, y un régimen de exención de responsabilidad civil para quienes lo hagan; un sistema de registro y reporte de transacciones en efectivo de dinero de cantidades considerables, así como dotar a las autoridades fiscalizadoras de capacidad para establecer procedimientos generales y sanciones administrativas con motivo de la inobservancia por parte de un sujeto obligado de las obligaciones de prevención.

Finalmente, esta importante iniciativa sugiere la creación de Unidades de Análisis Financiero que recopile y analice las transacciones en efectivo y las consideradas sospechosas que se produzcan en el sistema; el establecimiento de evaluaciones permanente sobre el cumplimiento de este Plan de Acción, así como la conformación de un Grupo de Trabajo para elaborar una Convención Interamericana para combatir el lavado de activos.

\subsubsection{Declaración de Santiago}

En abril del año 1998 los Jefes de Estado y de Gobierno de las Américas asistieron a la Segunda Cumbre de las Américas, esta vez efectuada en Santiago de Chile, emitiendo en fecha 19 de abril de 1998 el "Plan de Acción II Cumbre de las Américas".

Entre los puntos tratados en este Plan de Acción, algunos se refieren al tema del lavado de activos, ya que se estimula a los Estados a "fortalecer las unidades centrales especializadas existentes, debidamente entrenadas y equipadas, encargadas de solicitar, analizar e intercambiar entre las autoridades estatales competentes, información relativa al lavado del producto y de los bienes e instrumentos utilizados en las actividades delictivas (también Ilamadas lavado de dinero)", así como también alienta "a las instituciones financieras a redoblar sus esfuerzos para evitar el lavado de dinero". 
Sin duda alguna, en lo que respecta al tema del tráfico de drogas y lavado de activos, el punto más resaltado por la Declaración de Santiago fue el relativo a fortalecer la alianza estratégica antidrogas del hemisferio sobre "la base de los principios de respeto a la soberanía y a la jurisdicción territorial de los Estados", por lo que decidieron crear en el marco de la "Comisión Interamericana para el Control y el Abuso de las Drogas" (CICAD$\mathrm{OEA}$ ), un proceso único y objetivo de evaluación gubernamental de carácter multilateral, para dar seguimiento al progreso individual y colectivo de los esfuerzos hemisféricos y de todos los países participantes de la Cumbre en el tratamiento de las diversas manifestaciones del problema". 53

\subsubsection{Declaración de Québec}

Esta Declaración es el resultado de la Tercera Cumbre de las Américas, efectuada en esa ciudad canadiense, en el año 2001. Al igual que las Declaraciones de las Cumbres anteriores, toca el tema relativo al lavado de activos y a la delincuencia organizada transnacional.

La Declaración de Québec acogió con beneplácito el desarrollo del "Mecanismo de Evaluación Multilateral" aprobado en la Cumbre de Santiago, reiterando el compromiso de hacer del mismo uno de los pilares centrales para la cooperación hemisférica eficaz. Recomienda impulsar el establecimiento de Unidades de Inteligencia Financiera en aquellos países que no lo hayan hecho, así como la ampliación de la capacitación realizada por la CICAD y el BID.

Otro punto importante de esta Declaración lo constituye el llamado que se hace a los Estados a firmar y ratificar la Convención de las Naciones Unidas contra la Delincuencia Organizada Transnacional, promoviendo especialmente la adopción de las técnicas de investigación comprendidas en esta Convención, ya que constituyen herramientas muy importantes en la lucha contra la delincuencia organizada.

\subsubsection{Declaración Política del GAFISUD}

Esta Declaración es el resultado de la reunión de Ministros y otros representantes de Gobiernos de la Región, reunidos en Cartagena de Indias, República de Colombia, del 7 al 9 de diciembre del año 200054, en la cual conformaron el Grupo de Acción Financiera Sudamericano (GAFISUD) suscribiendo el correspondiente Memorando de Entendimiento.

Los países que forman parte del GAFISUD son los siguientes: Argentina, Bolivia, Brasil, Chile, Ecuador, Paraguay, Perú y Uruguay.

El primer aspecto importante que surge de esta Declaración de Principios y del establecimiento del GAFISUD es la aplicación de las 40 Recomendaciones del GAFI, de las recomendaciones contenidas en la Declaración de 
Buenos Aires de 1995, así como el Reglamento Modelo elaborado por el Grupo de Expertos de Lavado de Activos de la Comisión Interamericana para el Control de Abuso de Drogas (CICAD).

Como consecuencia de haberse instituido el GAFISUD, los países miembros asumieron el compromiso de adoptar 15 recomendaciones, de naturaleza muy diversa, aunque referidas al mismo tema: el lavado de activos.

Estas recomendaciones contienen aspectos muy importantes y, en algunos casos, novedosos. Sugiere incorporar el lavado de activos provenientes de delitos adicionales al narcotráfico, como, por demás, ya estaba recomendado en el Convenio de Estrasburgo y en la Convención de las Naciones Unidas contra Ia Delincuencia Organizada Transnacional. Además, establecer como una obligación de los agentes económicos que participan en el comercio exterior, operaciones bursátiles, inversiones en inmuebles, juegos de azar, etc., obligaciones de control, reporte y auto control.

Finalmente, resulta notable destacar en esta Declaración de Principios y Recomendaciones, la relativa a establecer "la obligación de agentes económicos de adoptar un Código de Ética o de Conducta y un Manual de Procedimiento para la prevención, detección y control del lavado de activos", fijando con claridad la actividad esperada y la responsabilidad de sus funcionarios "en una cultura de control en que se antepongan los principios y valores al logro de metas comerciales".

\section{Propuestas Normativas}

Las iniciativas internacionales en materia de lavado de activos no se han limitado a Convenciones Internacionales, Recomendaciones y Declaraciones de instancias de trascendencia en la esfera internacional, creación de Grupos de Trabajos en la misma esfera, sino que además se han orientado hacia la elaboración de propuestas normativas, dada la necesidad de legislaciones uniformes. Es el caso del Modelo de Ley de PNUFID, y el Reglamento Modelo OEA.

\section{1. Modelo de Ley PNUFID}

Una de esas propuestas está contenida en la "Ley Modelo sobre blanqueo, decomiso y cooperación internacional en lo relativo al producto del delito", que sustituyó el modelo de "Legislación sobre el Blanqueo de dinero, el decomiso y la cooperación internacional en materia de drogas", cuya elaboración concluyó en noviembre de 1995, por el Programa de las Naciones Unidas para la Fiscalización Internacional de las Drogas. 
Esta Ley Modelo consta de cinco títulos: un primer título dedicado a generalidades, tales como definiciones y terminología; un segundo título, relativo a la prevención del lavado de dinero, el cual consta de dos (2) capítulos, uno que contiene disposiciones generales de prevención, y otro que se refiere a la transparencia de operaciones financieras; un tercer título, que trata sobre la detección del lavado de dinero, y consta de cuatro (4) capítulos, uno relativo a la colaboración con las autoridades encargadas de luchar contra el lavado de activos, otro relativo a la exención de responsabilidad, un tercero dirigido a las técnicas de investigación, y un cuarto que trata lo relativo al secreto bancario o profesional; un cuarto título, que versa sobre lo que tiene que ver con las medidas coercitivas, y tiene dos (2) capítulos, uno relativo a la incautación y demás medidas cautelares, y otro atinente a la represión de los delitos de lavado de activos y decomiso; y finalmente, el quinto título, destinado a la cooperación internacional, y que está dividido en tres capítulos relativos a las solicitudes de asistencia judicial internacional recíproca, de la extradición, y de los puntos comunes a ambos aspectos.

\subsection{Reglamento Modelo OEA-CICAD}

En el ámbito americano el Grupo de Expertos de Lavado de Dinero de la Comisión Interamericana para el Control del Abuso de Drogas (CICAD), de la Organización de Estados Americanos (OEA), ha elaborado el "Reglamento Modelo sobre delitos de lavado relacionados con el tráfico ilícito de drogas, y otros delitos graves".

Este Reglamento Modelo ha sido objeto de modificaciones por el mismo grupo de expertos que lo redactó, efectuadas en Santiago de Chile, 1997; Washington, D.C., mayo de 1998, en Buenos Aires; octubre de 1998, y en México, D.F., julio 2002.

Esa propuesta normativa otorga un tratamiento íntegro al lavado de activos, ya que comprende aspectos penales, procesales y administrativos. Tipifica el lavado de dinero como un delito autónomo, le otorga alcance extraterritorial, y consagra reglas eficaces en materia de incautación y decomiso de bienes, protección de terceros de buena fé y cooperación internacional.

Recomienda asimismo la creación de Unidades de Información o Análisis Financiero para la depuración de las transacciones sospechosas remitidas por los sujetos obligados (instituciones financieras, empresas de bienes raíces, de joyas, casinos etc.), a las cuales, por igual, les determina sus obligaciones para facilitar la prevención y detección de operaciones de lavado de activos.

Incluye, además, el Reglamento Modelo elaborado por CICAD lo relativo al levantamiento del secreto bancario y a la exención de responsabilidad penal, civil y administrativa por reportes de transacciones sospechosas cuando se efectúen de buena fé.

\footnotetext{
1 Estos esfuerzos inclusive anteceden a la primera Convención sobre el tema, la Convención de Viena de 1988, como se expone más adelante.
} 
2 Con anterioridad habían sido aprobadas en el pasado siglo, la Convención de la Haya de 1912, la Convención Única sobre Estupefacientes de 1961 , y la Convención de Viena sobre los Sicotrópicos de 1971, pero estas no hacían referencia al tema del lavado de activos, etc.

3 Ver Jose Luis Conde, ob. cit.

4 Abel Souto, Miguel. El blanqueo de dinero en la normativa internacional, pág. 85

5 Aranguez Sanchez, Carlos. El Delito de Blanqueo de Capitales, pág. 152

6 Langon Cuñarro, Miguel. "La Convención de Viena de 1988 y los Reglamentos modelo sobre delitos de lavado de dinero y precursores químicos de estupefacientes y psicotrópicos". Revista del Instituto Uruguayo de Derecho Penal. No.12, pág. 1992.

7 El Art. 5.7 de la Convención de Viena expresa: "Cada una de las Partes considerará la posibilidad de invertir la carga de la prueba respecto del origen lícito del supuesto producto u otros bienes sujetos a decomiso, en la medida en que ello sea compatible con los principios sujetos a su derecho interno y con la naturaleza de sus procedimientos judiciales y de otros procedimientos".

8 El Art. 5 de la Convención está dedicado por completo a este tema..

9 El Art. 5.8 de la Convención dice: "Lo dispuesto en el presente artículo no podrá interpretarse en perjuicio de los derechos de terceros de buena fé".

10 Art. 7 de la Convención.

11 Art. 5 a) ii) de la Convención: "Repartirse con otras Partes, conforme a un criterio preestablecido o definido para cada caso, dicho producto o de dichos bienes, o los fondos derivados de la venta de dicho producto o de dichos bienes, con arreglo a lo previsto por su derecho interno, sus procedimientos administrativos o los acuerdos bilaterales o multilaterales que hayan concertado a este fin".

12 Abel Souto, Miguel. El blanqueo de dinero en la normativa internacional, pág. 116.

13 Art. 5 de la Convención.

14 Art. 8 de la Convención.

15 Art. 6 de la Convención.

16 Art. 7 de la Convención.

17 Art. 68.1 de la Convención.

18 Arts. 31, 53 y siguientes de la Convención.

19 Art. 46 de la Convención.

20 Art. 37 del Convenio.

21 Abel Souto, Miguel. ob. cit., págs. 150 y 151.

22 Y también de la Convención de Palermo del 2000, y de la Convención de las Naciones Unidas contra la Corrupción.

23 Art. 1, letra e) del Convenio.

24 Art. 6 del Convenio.

25 Arts. 7 y siguientes.

26 Art. 4 del Convenio.

27 Art. 6.2 del Convenio.

28 Art. 7.2, letre e), de la Convención.

29 Art. 23.2, letra e) de la Convención.

30 Art. 1 de la Directiva.

31 Art. 3.1 al 3.4, de la Directiva.

32 Art. 3.5 de la Directiva.

33 Art. 6 de la Directiva.

34 Art. 7 de la Directiva.

35 Art. 2 Bis, numerales 3,4 y 5. 


\begin{abstract}
36 Preámbulo de la Convención.
37 La Ley 72-02, sobre Lavado de Activos prevé en su Artículo 1, numeral 7, como una infracción grave capaz de generar recursos envueltos en el lavado de activos "cualquier crimen relacionado con el terrorismo".

38 Estos instrumentos internacionales son los siguientes: Convención Internacional contra la toma de rehenes; Convenio sobre la protección física de los materiales nucleares; Protocolo para la represión de actos ilícitos de violencia en los aeropuertos que prestan servicios a la aviación civil internacional; Convenio para la represión de actos ilícitos contra la seguridad de la navegación marítima; Convenio Internacional para la represión de los atentados terroristas cometidos con bombas y Convenio Internacional para la represión de la financiación del terrorismo.
\end{abstract}

39 Art. 4.1.a de la Convención.

40 Art. 4.1. b de la Convención.

41 Art. 4.1.c de la Convención.

42 Art. 4.2 de la Convención.

43 Las Unidades de Análisis o Inteligencia Financiera son entidades de cada país que sirven de central de datos respecto del reporte de transacciones financieras sospechosas realizados por los sujetos obligados al cumplimiento de obligaciones de prevención.

44 Blanco Cordero, Isidoro, ob. cit. pág. 171.

4530 de noviembre de 1995.

46 22-23 de abril de 1996.

47 21-22 de noviembre de 1996.

48 23-24 de junio de 1997.

49 Al respecto pueden señalarse la de Buenos Aires del 30 de junio al 1 de julio de 1998, y la de Slovaquia, del 26 al 28 de mayo de 1999.

50 "organismo gubernamental, central y nacional, encargado, a los fines de luchar contra el lavado de activos, de recibir, solicitar, analizar y transmitir a las autoridades competentes las comunicaciones de informaciones financieras concernientes a los productos de origen presumiblemente criminal, 0 requeridos por la legislación o reglamentación nacional.

51 En abril de 1990.

52 El 30 de octubre del 2001.

53 Estas recomendaciones son de transcendental importancia hasta el punto de que organismos financieros de relevancia mundial como el Fondo Monetario Internacional y el Banco Mundial las reconocen como los estándares internacionales frente al lavado de activos.

54 Recomendación No. 1.

55 Recomendación No. 3.

56 Recomendación No. 5.

57 Recomendación No. 10.

58 Recomendaciones Nos. 11 y 13.

59 Recomendación No. 14.

60 Recomendación No. 15.

61 Recomendación No. 23.

62 Recomendación No. 6.

63 Abel Souto, Miguel, ob. cit. pág. 59.

64 Se refiere al problema que generaban las certificaciones anuales americanas. Tema del MEM.

65 Con ello se cumplió el mandato de la Cumbre de Presidentes de Sudamérica, efectuada en Brasilia el 1ro. de septiembre del 2000. 



\section{3 \\ EL LAVADO DE ACTIVOS EN LA LEGISLACIÓN DOMINICANA}

Alejandro Moscoso Segarra

\section{Introducción. La complejidad del tipo penal del lavado de activos}

El fenómeno del lavado de activos comporta una serie de actividades que nos permiten verlo con características muy particulares y especiales, que lo diferencian de manera significativa de las demás actividades criminales.

El crimen de lavado, como toda infracción penal, debe ser analizado partiendo de los elementos que lo componen y tipifican como tal.

La incorporación de este tipo penal a la legislación represiva de la República Dominicana obedece a un factor o realidad fundamental; la criminalidad organizada y, en sus orígenes, el crimen relacionado con el narcotráfico.

Como afirma un autor, "desde el prisma jurídico penal, el desafío de la criminalidad organizada repercute tanto en la teoría del delito y de la sanción como, sobretodo, en la definición misma del fenómeno. Y la conveniencia (y urgencia) de creación de nuevos tipos penales o de la remodelación de las antiguas figuras delictivas que permitan atinar con los comportamientos característicos de las organizaciones criminales, atacando de la manera más directa posible a sus intereses ilegítimos".1

A diferencia de lo que sucede con la legislación referida a la delincuencia más tradicional, en el caso de la ley que reprime el lavado de activos en nuestro país, dicha regulación se manifiesta no sólo a través de un tipo penal que remite siempre a un verbo típico, sino que se presenta de un modo mucho más complejo, teniendo en cuenta que se trata de varias formas de regulación de distintas conductas (incluso omisivas) que pueden describirse a partir de varios verbos típicos. Es decir y para ser más claros: no hay un solo tipo penal de lavado de activos sino varios, y que pueden presentar distintas características. Incluso, ello es visible en relación con la etapa temporal en la que intervienen los distintos sujetos activos. Por ejemplo, y ante un caso individual, es 
posible que frente al mismo proceso de lavado de capitales un sujeto activo sea responsable de "adquirir", otro sujeto activo de "ocultar" y otro de "otorgar asistencia", y todos serán autores (coautores o autores "paralelos") con relación a los mismos fondos de origen delictivo.

Esta complejidad intrínseca de la legislación que reprime el lavado de activos aumenta la necesidad del desarrollo del fino criterio hermenéutico del intérprete y sugiere como inevitable el desarrollo de especiales criterios de imputación.

\section{Origen y evolución de la tipificación del lavado de activos en la República Dominicana}

Para analizar los orígenes y la evolución de la tipificación del crimen de lavado de activos en la República Dominicana, debe partirse de la línea de acción trazada por la comunidad internacional, que ha impactado de manera significativa en nuestro ordenamiento jurídico penal sustantivo, dando origen a normativas que han ido adaptándose a la realidad jurídico-penal de nuestro país.

En el tema anterior se aprecia el marco internacional del lavado. Sin embargo, es oportuno analizar lo relativo al tratamiento que le da la Convención de Viena a la tipificación del crimen, en razón de que este importante instrumento jurídico internacional, además de formar parte de nuestro ordenamiento jurídico nacional, tuvo una fuerte incidencia en todas las normativas vigentes que prevén y reprimen el lavado de activos en nuestro país.

Para poder abordar el origen de la tipificación del lavado necesariamente hay que partir de la Convención de Viena. Este análisis debemos verlo conjuntamente con la normativa nacional.

En la República Dominicana comenzó a verse la necesidad de tipificar el lavado de activos partiendo de la urgencia de impedir que los bienes procedentes del crimen previo del narcotráfico fueron insertados o colocados en la economía nacional dando la apariencia de haber sido obtenidos de forma legítima.

Nuestro vetusto código penal del 1884 no prevé dentro de sus artículos el tipo penal de lavado de activos. Son leyes especiales, a partir de la década de los años 80 que vienen a llenar este vacío. Sin embargo, debe señalarse que es precisamente en esa década cuando los países del mundo empiezan a preocuparse para que sus respectivos ordenamientos jurídicos tipifiquen la infracción que nos ocupa partiendo casi todos de la Convención de Viena de 1988. 
del trasiego de las drogas, como lo han expresado unos autores. "Ia situación geográfica dominicana hace del país uno de los denominados "países puentes de las drogas", otros factores de índole social y económicos como son la emigración dominicana a los Estados Unidos, la vinculación con el narcotráfico y el crimen organizado de las colonias de inmigrantes dominicanos y la repatriación de sus ganancias ilícitas a través de canales que ya hemos mencionado, o evidenciadas en inversiones de las mas variadas características y dimensiones, han incluido a la nación dominicana en el listado de países de alto riesgo en lo referente al lavado del dinero".2

\subsection{Ley 50-88 del 30 de mayo de 1988}

Partiendo de lo anterior la primera ley especial dirigida a reprimir y prevenir el narcotráfico en nuestro país fue la Ley 168 del 12 de mayo de 1975. Esta disposición, sin embargo, no tipificaba el crimen del lavado de activos, en ninguno de sus artículos, además de que resultaba ineficaz en aquellos momentos como instrumento legal para prevenir y reprimir el tráfico de drogas.

La Ley 50-88 del 30 de mayo de 1988 viene a derogar la antigua ley 168 y a incorporar a nuestro ordenamiento jurídico penal el tipo de "lavado" en su articulo 58, cuando expresa que se considera como delitos graves "la adquisición, posesión, transferencia o "Iavado" de dinero o cualesquiera otros valores, así como las ganancias derivadas de o usadas en el tráfico ilícito".

Como puede apreciarse de la trascripción de ese artículo, la Ley 50-88 incorpora por primera vez en el ordenamiento jurídico tres verbos rectores, Adquirir, Transferir y Poseer, que se presentan en el mismo artículo como la conducta típica que crea la infracción de "Iavado".

Más adelante se verá la conducta típica del encubrimiento establecida la ley 50-88 que se recoge en el artículo 3 de la Ley 72-02.

\subsection{La ley 17-95 del 17 de diciembre de 1996}

Una vez la Convención de las Naciones Unidas contra el Trafico llícito de Estupefaciente y Sustancias Psicotrópicas fue ratificada por el Congreso Nacional y promulgada por el Poder Ejecutivo, se generó toda una corriente dirigida a adaptar nuestro marco jurídico al más importante instrumento jurídico de carácter internacional en materia de drogas y lavado de activos.

Las iniciativas legislativas de ese entonces dieron origen dos años más tarde, a la Ley 17-95 del 17 de diciembre de 1995. La misma introduce varias modificaciones e inserta 17 artículos, que prevén todo lo 
relacionado al lavado de activos en nuestro país.

Para los fines de este tema, se considera de interés ver los artículos 99, 100 y 101 de esa ley, que describen los verbos que tipifican el lavado y que fueron asumidos más tarde por la ley 72-02:

Artículo 99. El que a sabiendas, por omisión o comisión convierta o transfiera bienes que sean producto de un delito de tráfico ilícito de drogas controladas o delitos conexos, previsto en esta ley, será sancionado con reclusión de 2 a 5 años y multas de RD\$50,000.00 (Cincuenta mil pesos) a RD\$100,000.00 (Cien mil pesos con 00/100).

Artículo 100. Toda persona que adquiera, posea, transfiera, tenga o utilice bienes a sabiendas de que tales bienes hayan sido producto de un delito de tráfico de drogas controladas o delitos conexos previstos en esta ley, será sancionada con reclusión de 2 a 5 años y multas de RD\$50,000.00 (Cincuenta mil pesos) a RD\$100,000.00 (Cien mil pesos con 00/100).

Artículo 101. Toda persona que a sabiendas ocultase, encubriese, o impidiere la determinación real de la naturaleza, origen, ubicación, destino, movimiento o propiedad de bienes o de derechos relativos a tales bienes que hayan sido producto e un delito ilícito de tráfico de drogas o delitos conexos previstos en esta ley serán sancionado con reclusión de 2 a 5 años y multas de RD\$50,000.00 (Cincuenta mil pesos) a RD\$100,000.00 (Cien mil pesos con 00/100).

PARRAFO. Son delitos conexos para los fines de la presente ley las acciones o actividades establecidas en los artículos 99,100 y 101 encaminadas a facilitar el lavado de dinero.

\subsection{Ley $72-02$ del 29 de mayo de 2002}

La Ley 72-02 del lavado de activos proveniente del trafico ilícito de drogas y sustancias controladas y otras infracciones graves viene a adecuar el marco jurídico dominicano a los lineamientos internacionales en lo que respecta al lavado de activos y a recoger en un solo cuerpo jurídico todo el sistema normativo sobre la materia.

Esta disposición derogó de manera expresa el párrafo del artículo 76 y los artículos del 99 al 115 de la ley número 50-88, modificados, por la ley 17-95.

Más adelante se abordará el sistema normativo de la ley 72-02 en lo que respecta al delito propiamente del lavado de activo. 
Con relación a la historia legislativa en asunto de lavado en la República Dominicana debe señalarse que existe en el Congreso un anteproyecto de código penal, en el cual se le da un tratamiento diferente desde el punto de vista penal a la infracción criminal.

Ese proyecto de ley incorpora la figura penal objeto de estudio en los artículos 453 al 461 . En el artículo 453 el anteproyecto de marras crea un término empleado por las legislaciones europeas, el de blanqueamiento, cuando expresa: "El blanqueamiento es el proceso u operación económica mediante la cual se trata de justificar que tienen origen lícito, bienes, dinero, valores títulos o recursos obtenidos como fruto de actividades criminales o delictuosas. Constituye igualmente el blanqueamiento toda actuación u operación económica tendiente a invertir en empresas, negocios o bienes de toda especie cuya legalidad es aparente, los frutos directos 0 indirectos de un crimen o un delito".

Como puede verse, ese artículo configura una conducta típica más general que la establecida por las demás normativas nacionales que tipifican la infracción, y emplea una fórmula más amplia, en la que adquiere relevancia penal cualquier conducta tendente a obstaculizar la identificación de la ilícita procedencia de los bienes, sin que aparezcan determinados los métodos que pueden utilizarse.

\section{El sistema normativo de la ley $72-02$}

Para tener una idea clara del sistema de la Ley 72-02, de modo genérico y sin entrar por ahora en detalles dogmáticos, conviene tener presente de qué modo el legislador ha encarado la regulación del sistema represivo de la conducta en cuestión.

La ley contiene un Capítulo I en el cual se produce una serie de definiciones de conceptos que son esenciales en el sistema represivo. Es así como se refiere, a fin de evitar confusiones semánticas, a los vocablos: activos, autoridades competentes, bienes, etc.

Luego, el Capítulo II se ocupa de plantear el objetivo político-criminal de la Ley 7202, consistente en básicamente definir conductas prohibidas, establecer los mecanismos para la prevención, crear los órganos de coordinación, y resolver el problema de la asistencia internacional.

El Capítulo III, que se ocupa de definir las conductas típicas en el plano objetivo y subjetivo contiene varias secciones: la II en la cual, el legislador ha previsto una serie de medidas cautelares con relación a bienes, productos o instrumentos relacionados con la infracción; la III, donde se definen las sanciones penales para cada tipo de infracción y los distintos niveles de participación; la IV, donde el legislador se ocupa del decomiso 
de los bienes y su destino, en los casos en los cuales los autores sean condenados, y la V, en la cual la ley se hace cargo de la situación de los terceros de buena fe, y define los casos en los cuales los bienes deben ser reintegrados a esos terceros.

En el capítulo IV el legislador define un sistema preventivo de detección del referido delito. Se ocupa de definir las obligaciones de un conjunto de entidades o personas, como el cumplir mandatos de identificación de clientes, reporte de transacciones en efectivo, y/o sospechosas, etc., En la sección III de este Capítulo se encuentra una serie de sanciones administrativas y el sistema procesal para esa aplicación.

El capítulo V se encarga de definir la competencia y funciones del Comité Nacional contra el Lavado De Activos, que está integrado por el Presidente del Consejo Nacional de Drogas, el Procurador General de la República, el Secretario de Estado de Finanzas, el Superintendente de Bancos, y el Presidente de la Dirección Nacional de Control de Drogas.

Por último, el Capítulo VI define el sistema de cooperación internacional en el derecho interno.

\section{La conducta típica del lavado de activos en la ley 72-02}

El artículo 3 de la Ley 72-02 de lavado de activos de la República Dominicana, describe las distintas conductas típicas que constituyen esta infracción.

En el tema relativo al marco internacional se aprecian las pocas diferencias que existen respecto a los principales documentos jurídicos internacionales que abordan la problemática, de manera especial la Convención de Viena en cuanto a las conductas típicas que se analizarán.

El artículo 23 de la Ley 72-02 establece que, "a los fines de la presente ley, incurre en lavado de activos la persona que a sabiendas de que los bienes, fondos e instrumentos son el producto de una infracción graves.

(a) Convierta, transfiera, transpire, adquiera, posea, tenga, utilice o administre dichos bienes.

(b) Oculte, encubra o impida la determinación real, la naturaleza, el origen, la ubicación, el destino, el movimiento o la propiedad de dichos bienes o derechos relativos a tales bienes, $\mathrm{y}$

(c) Se asocie, otorgue asistencia, incite, facilite, asesore en la condición de alguna de las infracciones tipificadas en este articulo, así como a eludir las consecuencias jurídicas de sus acciones." 


\subsection{Elementos del tipo objetivo del lavado de activos}

Las conductas típicas descritas por el artículo 3 serán analizadas de forma particular, pero es importante, previamente, hacer algunas precisiones sobre la tipicidad.

El término tipo corresponde a una traducción libre de la expresión alemana Tatbestand, pero también se usa para significar lo que en alemán se denomina comotipus o delikt-tipus.

Como lo describe el manual de apoyo para la tipificación del delito del lavado "el tipo es una creación abstracta y formal que se construye sobre un hecho, sobre un acontecimiento, que se desarrolla en el ámbito de los fenómenos causales. Dicho en otras palabras el delito consiste esencialmente en el tipo el hecho concreto, "se adecua" al tipo, pero no es el tipo". ${ }^{3}$ Continúa señalando el manual que "de este modo, la cualidad que identifica la conducta delictiva no es el tipo sino la tipicidad, es decir la conformidad entre el hecho concreto y la descripción abstracta".

Partiendo de lo anterior, el tipo es visto como un conjunto de características objetivas y subjetivas (externa e interna o mentales) que constituyen la materia de prohibición para cada delito en específico.

En este tema nos interesa ver la fase objetiva del tipo conocido como lavado. La infracción como tal puede contar únicamente de una acción típica. Sin embargo, puede darse el caso de que su descripción se enlace con un resultado y ambos sean prohibidos. La acción en un tipo penal es referida mediante un verbo rector que ocupa el centro de la descripción, por ejemplo, uno de los verbos rectores del lavado es convertir. Es sano resaltar que el verbo rector no se termina con la descripción de la conducta, sino que esta acción típica requiere, además, de un sujeto y los complementos, que serán vistos en el artículo 3 de la ley 72-02 que se analiza. En cuanto al sujeto activo que indica el referido artículo es cualquier persona, el mismo señala que "incurre en el lavado de activos la persona que....." es decir, deja abierto a que el sujeto activo del delito sea cualquier individuo, sin distinción, y no exige la concurrencia de determinada calidad.

Las conductas típicas descritas en el artículo 3 de nuestra normativa sobre lavado, de manera enunciativa son las siguientes convierta, transfiera, transporte, adquiera, posea, tenga, utilice, administre, oculte, encubra, impida, incite, facilite, se asocie, asista y asesore.

Uno de los objetivos de la ley 72-02 es precisamente como se señala en el artículo 2 acápite A, el de definir las conductas en el lavado de activos.

Pasemos a analizar cada uno de estos elementos del tipo objetivo, aunque no necesariamente en el mismo 
orden que se presenta en el artículo sujeto de estudio. Pero antes es oportuno precisar que el artículo en cuestión se refiere a que los bienes que se legitiman son el producto de una "infracción grave", abriendo con esto un abanico de crímenes o delitos distintos al narcotráfico que dejó de ser, a partir de esta disposición, el único crimen previo a que el producto sea lavado.

La misma Ley en su artículo 1 acápite 7, describe las infracciones graves de la siguiente manera: "Se entiende por infracción grave el tráfico ilícito de drogas y sustancias controladas, trafico ilícito de armas, cualquier crimen relacionado con el terrorismo, tráfico ilícito de seres humanos (incluyendo inmigrantes ilegales), tráfico ilícito de órganos humanos, secuestro, la extorsiones relacionadas con las grabaciones y fílmicas electrónicas realizadas por personas físicas o morales, robos de vehículos cuando el objeto sea trasladado a otro territorio para su venta, proxenetismo, falsificación de monedas, valores o títulos, estafa contra el estado, desfalco, concusión y soborno relacionado con el narcotráfico. Así mismo se considera como una infracción grave todos aquellos delitos sancionados con una pena no menor de 3 años".

Como puede verse en su último párrafo abre aún más el espectro de los delitos sancionados con penas no menores de 3 años, siempre y cuando estos delitos generen bienes que puedan insertarse en la economía.

\subsubsection{Conductas típicas}

\section{La conversión o transferencia}

En el tema I de este texto se abordaron las tres etapas del lavado de activos: colocación, encubrimiento y reinversión. En las conductas que se verán a continuación podrá apreciarse donde se encuentran esas fases o etapas.

La conversión y transferencia son actos que en definitiva suponen la transformación de unos bienes a otros, lo que conlleva a la ocultación del ilícito origen de estos.

Sobre él término típico conversión existen varios puntos de vista, por lo que es conveniente ver en detalles en que consiste la conversión de los bienes procedentes de crímenes graves.

El Diccionario Enciclopédico de Derecho Usual, de Guillermo Cabanellas, define la conversión como "Ia transformación de un acto nulo en otro eficaz mediante la confirmación o convalidación" o también la "acción o efecto de convertir" y convertir es "cambiar, modificar o trasformar algo." La transferencia es definida en el mismo diccionario como "paso o conducción de una cosa de un punto a otro", también como "el traspaso de un derecho de una persona a otra conservando el derecho de su identidad". Por ejemplo, la transferencia 
electrónica o en plural de dinero de una cuenta bancaria a otra.

Por otro lado, otros autores consideran la conversión o transferencia como un delito de lavado de activos "stricto sensu".

El objetivo de estas conductas es el de transformar un bien por otro con la intención de legitimarlo, es decir, que el producto de origen ilegítimo se convierte en legítimo.

Isidoro Blanco considera que la acción típica de convertir, "estimando que hace referencia a la transformación de los bienes también es una medida positiva, pues es un ejemplo de acciones características del lavado de bienes de origen delictivo que permite una interpretación adecuada de las posteriores conductas consistentes en la realización de cualquier acto sobre los bienes".

\section{Transfiera /transporte}

Como pudo verse, la mayoría de las doctrinas ven el convertir y transferir como las dos conductas esenciales del crimen del lavado y algunos llegan a plantear que los demás verbos rectores utilizados son "formas especiales de encubrimiento". 4

En el artículo 3 de la ley 72-02, el segundo y tercer verbos empleados son los de transferir y transportar podrían confundirse como verbos sinónimos para el caso del lavado, por lo que resulta importante hacer algunas precisiones partiendo de las acepciones gramaticales que nos brinda Guillermo Cabanellas. Según él, transferir es "pasar o mudar algo / conducir de un punto a otro, transportar, transmitir / enajenar, traspasar / en especial transmitir el dominio o derecho sobre algo". 5 En cambio, transporte es visto en el diccionario mencionado como "traslado, conducción de personas o cosas entre dos lugares".

En el caso de la transmisión podríamos verla aquí, desde el punto de vista del derecho civil, como la acción de traspasar o transferir el derecho de una persona a otra conservando el derecho su identidad, es decir, que como plantea Isidoro Blanco Cordero la transmisión se define de acuerdo con el concepto civil "como traspaso de los derechos sobre los bienes procedentes de un delito grave".

Cuando se emplea el verbo transportar podría decirse que el legislador se refiere de manera particular al traslado como tal de bienes productos de infracciones graves. Esta conducta podría asimilarse a la establecida en el artículo 8 de la ley 72-02 cuando impone sanciones para "la persona nacional o extranjera, que al ingresar 0 salir del territorio nacional por vía aérea, marítima o terrestre portando dinero o títulos valores al portador o que envié los mismos por coreo publico o privado cuyo monto exceda la cantidad de diez mil dólares 
(US\$10,000.00), moneda de los Estados Unidos de América u otra moneda extranjera o su equivalente en moneda nacional no la declare o declare falsamente su cantidad en los formularios preparados al efecto". Aunque este acápite se refiere a la no declaración de los bienes es utilizado en aquellos bienes que son transportados.

El acápite A del artículo que se analiza utiliza esos verbos rectores, sujeto de explicación, como son adquirir, poseer, tener, utilizar o administrar bienes. Estas conductas típicas las podemos ver de igual manera en la Convención de Viena (artículo 3), Reglamento Modelo CICAD (artículo 2), proyecto PNUFID (artículo 21), Convención de Palermo (artículo 6) y I Convenio Centroamericano (artículo 2).

\section{La adquisición}

Esta implica toda compra, cambio o permuta de bienes, que podrían ser valores mobiliarios, obtención de empresas, etc.

Es el acto por el cual uno se hace dueño de una cosa. El manual de la CICAD, señala con rigor que solo incluye lo que se alcanza por dinero, ajuste, habilidades u otros títulos, más no los que vienen por derecho de herencia. Esta conducta solo se establece para terceros es decir, que no cubre al autor del delito que dio origen al lavado.

\section{La posesión}

El vocabulario jurídico de Henry Capitant define la posesión como "la situación del que ejerce de derecho las prerrogativas propias de un derecho y se comporta como su verdadero titular". 6

Propiamente, posesión es el poder de hecho y de derecho sobre una cosa material constituido por elemento intencional o animus (la creencia y propósito de tener las cosas propias) y el elemento físico o corpus (la tenencia o disposición efectiva de un bien material).

El verbo siguiente a la posesión es tener, que se observa en ocasiones como sinónimo a poseer, pero si se establece una medición en la relación originada entre el hombre y la cosa puede diferenciarse la tenencia, la posesión y, si se quiere, la propiedad sobre una cosa.

Algunos han definido la tenencia, como el manual de apoyo de la CICAD, "a la ocupación corporal y actual, sin título que permita disfrutarla ni adueñarse de ella sin buena fe, clandestinamente o por una mera tolerancia del dueño reconociendo el dominio ajeno. Mientras la posesión, como ya se dijera, agrega el hecho de hacer la cosa como propia o el propósito de consolidar la situación". 


\section{Utilizar 0 administrar}

El verbo utilizar en el caso que nos ocupa lo asimilamos al uso o usufructo de activos, sacando beneficios de estos aunque pertenezcan a otra persona, es decir, "servirse de una persona o cosa con determinada finalidad." Algunos han llegado a argumentar que la utilización de los bienes provenientes de crímenes no constituye "per se" lavado de activos sino "un aspecto económico del delito que debe ser tratado en cualquier esquema de lucha contra el blanqueo de fondo".7

El reglamento modelo de la CICAD establece que la finalidad de la ley es la de castigar la participación en el uso, aprovechamiento o destino de los bienes respecto de los cuales se conoce su procedencia ilícita y que es muy difícil probar la sola intención de darle un uso, aprovechamiento o destino determinado.

Con relación al verbo administrar éste ha sido empleado en otras legislaciones, aunque en realidad fue incorporado en la nuestra por influencia del reglamento modelo de la CICAD. El término administrar en derecho civil significa la "acción de administrar un bien, un conjunto de bienes o un patrimonio".8 Gramaticalmente se define como "ordenar, disponer, organizar en especial la hacienda o los bienes".

Con la introducción de esta conducta en nuestro marco jurídico se busca no excluir del crimen a cualquier persona que se haga cargo de los bienes o intereses producto del crimen organizado.

El Acápite B, del artículo 3 de la Ley 7202 recoge tres conductas importantes, ocultar encubrir e impedir. Algunos expertos en sus estudios han dedicado un análisis detenido a estas conductas con especial atención a las dos primeras. Los verbos ocultar y encubrirlos asimilamos del artículo 3.1 de la Convención de Viena que los describe.

Asimismo, el reglamento modelo de la CICAD incidió en la redacción del artículo 3 ya que el mismo extiende la tipificación no solo a quien oculte o encubra sino a quien impida la determinación real de la naturaleza, el origen, la ubicación, el destino, el movimiento o la propiedad de los bienes o derechos relativos a todos los bienes. Los redactores del reglamento modelo de la CICAD, al introducir el verbo de impedir, parecería que este está de más, en el entendido de que quien impide la determinación del origen, naturaleza, etc. de los bienes, en realidad oculta o encubre los mismos. Sin embargo, el término no sobra en el sentido de que se persigue evitar cualquier interpretación que tenga como propósito liberarse del castigo correspondiente.

En lo que respecta a la ocultación, para su real significado, se parte de la definición que brinda el diccionario de la Real Academia Española, de que ocultar implica "esconder, tapar, disfrazar, encubrir a la vista". Existen diversas posiciones doctrinarias sobre la definición de la ocultación. Algunos argumentan que la ocultación 
debe verse no solo como "acto de tapar o encubrir un hecho, objeto o persona, sino cualquier otro tendente hacer desaparear de la escena jurídica, los elementos sobre los que el encubrimiento recae". 9

Véase la ocultación como la sustracción de una cosa que se hace para quitarla de donde puede ser vista y colocarla donde se ignore que está. Isidoro Blanco Cordero señala que la doctrina admite que la ocultación puede realizarse bien mediante una conducta activa -esconder, disfrazar o tapar-, bien mediante una conducta pasiva, callar lo que se conoce. La activa, que comprende acciones con un propósito manipulador o clandestino, se efectúa en el tráfico económico y está basada en la confianza y transparencia. La acción de omitir consiste en silenciar lo que se puede o debe decir.

Sobre la conducta de omisión se plantea la necesidad de que pueda existir algún nivel de responsabilidad penal de que el imputado tenga una obligación jurídica de informar la acción.

\section{El encubrimiento}

En lo que se refiere al encubrimiento debe señalarse que la Ley 50-88, en sus artículos del 71 al 74, tipifica el encubrimiento u ocultación de los bienes procedentes de actividades ligadas al narcotráfico. De la lectura de esos artículos puede apreciarse cómo se amplían los verbos rectores para castigar el encubrimiento. Veamos estos artículos.

Artículo 71. Quien después de cometido un delito relacionado con drogas controladas, sin haber participado en el, ayude a asegurar a provecho, eludir las investigaciones de la autoridad, sustraerse a la acción de esta o del cumplimiento de la condena, será sancionado como encubridor, con prisión de dos (2) años a cinco (5) años, y de multa de dos mil (RD\$2,000.00) a diez mil (RD\$10,000.00).

Artículo 72. El que a sabiendas, por sí o por interpuestas personas, física o moral, realice con otras personas o con establecimientos comerciales o de cualquier naturaleza, transacciones comerciales de cualquier tipo, o suministre información falsa para la apertura de cuentas o para la realizaciones de la misma naturaleza, con dinero proveniente de las actividades del trafico ilícito de drogas controladas, con prisión de dos (2) años a cinco (5) años, y de multa de dos mil (RD\$2,000.00) a diez mil $(\operatorname{RD} \$ 10,000.00)$.

Artículo 73. Quien después de cometido un delito relacionado con drogas controladas, sin haber participado en él, oculte o adquiera o reciba dinero, valores u objetos o cualquier otro modo intervenga en su adquisición, captación u ocultación, será sancionado como encubridor, con prisión de dos (2) años a cinco (5) años, y de multa de dos mil (RD\$2,000.00) a diez mil (RD\$10,000.00). 
Artículo 74. Los establecimientos comerciales o de cualquier otra naturaleza que encubra las actividades relacionadas con los dineros y valores provenientes del trafico ilícito de drogas controladas, violando las disposiciones de esta ley, serán sancionados con el cierre definitivo e irrevocable, y con multa de cien mil (RD\$100,000.00) a quinientos mil (RD\$500,000.00).

Partiendo de la definición que hemos visto del Lavado, puede señalarse que las actividades enunciadas en esos artículos son particulares del crimen de lavado procedente del narcotráfico.

Esos artículos tipifican la infracción del encubrimiento, que no está establecida de manera expresa en nuestro código penal sino que podría ser asimilada a la complicidad.

Como se conoce, nuestro código penal es una adecuación del código penal francés, que trata el encubrimiento como una forma de participación a través de los llamados cómplices.

El caso del encubrimiento, previsto en la Ley 72-02 es diferente al encubrimiento regulado por la codificación napoleónica que se adoptó en 1884. Esta diferencia la presenta la Convención de Viena y la CICAD en su reglamento. En estas disposiciones comete la infracción solo aquel que sin haber tenido participación en un crimen determinado y sin concierto previo a la perpetración de cualquier crimen contribuye con el autor del mismo, con el propósito de asegurar el resultado del crimen, evitar el castigo o para obstaculizar el desempeño de la justicia.

Dice Saavedra Roja que la gran diferencia entre ocultar y encubrir puede residir en el hecho de que se oculta lo que es de uno o lo que está bajo la disponibilidad jurídica del autor, mientras que se encubre los actos de otros 0 bien sus bienes". Algunas legislaciones han adoptado el termino disimular por entender que el vocablo encubrimiento es asimilado por algunos como sinónimo de ocultación.

Es castigable el auxilio a los criminales que han cometido un crimen grave para que se beneficien de los bienes de tales violaciones. En este sentido y de acuerdo al acápite $B$, el encubrimiento no ha de recaer directamente sobre los bienes que tengan origen ilícito, sino sobre determinadas circunstancias propias de tales bienes, que son la naturaleza, el origen, la ubicación, el destino, el movimiento o la propiedad de dichos bienes o de derechos relativos a tales bienes.

El encubrimiento puede desdoblarse en actos positivos y pasivos. Se referirá a actos positivos, cuando la acción recaiga sobre el objeto regulado en el tipo o que sin incidir en tal objeto favorezca su aprovechamiento. Cuando los actos son pasivos podríamos verlos al momento de silenciar hechos que permitan a los responsables del crimen previo disfrutar de los bienes. 


\section{1.2. Otras formas de participación en el lavado}

Finalmente, con relación a las conductas típicas el acápite $C$ del artículo 3 de la ley 72-02 recoge una serie de acciones que son asimiladas de la convención de Viena y del reglamento modelo de la CICAD. Estas conductas son asociarse, otorgar asistencia, incitar, facilitar y asesorar.

Con estos verbos las legislaciones contemplan, en ocasiones de modo reiterativo, todas las posibilidades para lavar activos, con el objetivo de que no exista posibilidad alguna de que el crimen pueda consumarse.

Con relación al primer término "asocie", este tipo de crimen puede ser perpetrado por una sola persona, pero es frecuente que en su ejecución intervengan varias, que se distribuyen entre sí la tarea de realizar el hecho típico, es decir, situación de autoría. Tanto la asociación como la confabulación son entendidas como un concierto de voluntades ya para la comisión de un delito ya para perjudicar a terceros.

Con relación al verbo incitar debemos verlo a partir de la inducción, que es asimilada a la instigación.

Es instigador el individuo que de manera directa, crea en otro la decisión de llevar a cabo una conducta dolosamente típica y antijurídica. La Convención, al referirse al instigador, subraya "instigar o inducir públicamente a otros". De este modo tenemos previsto en nuestro ordenamiento jurídico, la Ley 72-02, y en la convención de Viena como figura autónoma a la incitación o instigación publica o privada a la comisión de la infracción que prevé el mismo marco jurídico.

Los verbos asistir, facilitar y asesorar son vistos como "figuras residuales" partiendo de que el legislador, a medida de que evolucionan los métodos empleados para lavar los activos, considera necesario ampliar las conductas típicas del crimen, con el propósito de que estas comprendan o recojan la mayor cantidad de conductas posibles.

\section{Elementos del tipo subjetivo del lavado de activos}

Para hacer intervenir al derecho penal, en la mayoría de los casos analizados, en el crimen de lavado no es suficiente que se realicen las conductas analizadas sino que se exige que los mismos vayan acompañados de un elemento subjetivo sin cuya presencia las conductas típicas carecerían de importancia.

Con esto se dice que el sujeto activo debe tener un propósito de ocultar el delito, origen de los bienes, o de ayudar a quien haya intervenido en el delito previamente cometido a eludir las consecuencias jurídicas de sus actos. 
En nuestro ordenamiento jurídico, específicamente en la Ley 72-02 en sus artículos 3 y 4, puede verse que está establecido el elemento subjetivo o dolo de la infracción. El artículo 3 establece que "a los fines de la presente ley incurre en lavado de activo la persona que, a sabiendas de que los bienes, fondos e instrumentos son, el producto de una infracción grave...", y el artículo 4 refiere que "el conocimiento, la intención o la finalidad requeridos como elementos de cualquiera de las infracciones previstas en esta sección, así como en los casos de incrementos patrimoniales derivados de actividades delictivas consignada en esta ley, podría inferirse de las circunstancias objetivas del caso".

El elemento subjetivo de las "a sabiendas" del artículo 3, viene de la Convención de Viena. Entre los elementos jurídicos internacionales que han incidido en las iniciativas legislativas de los países puede notarse diversidad de criterio para establecer el elemento subjetivo, en unos casos se circunscribe al dolo directo y en otros se amplía, por ejemplo el reglamento modelo de la CICAD recoge el "debiendo saber", expresión que fue asumida por los redactores del anteproyecto que luego fuera convertido en la Ley 72-02, pero que antes de su aprobación fue eliminado del mismo.

\section{El dolo: conocimiento y la voluntad de realizar el tipo objetivo}

La comisión, en principio, lleva consigo lo que se ha denominado el elemento moral o subjetivo.

El elemento moral es necesario para que la acción castigada o reprochada pueda ser imputada a su autor. Para establecer la culpabilidad debe manifestarse en el hecho delictuoso la acción antes señalada. En una sentencia importante en materia de lavado dada por la Corte Penal de Costa Rica en el caso contra Ricardo Allen León, conocida como la sentencia "Allen", en la motivación de dicha decisión la corte argumentó con relación al elemento subjetivo, "que el juicio de culpabilidad se da por medio del dolo; sea la voluntad del sujeto activo se dirige a la realización de un acto delictivo, conformándose este en el caso que nos ocupa como el conocimiento de los hechos, sea que tenga un conocimiento de las circunstancia descritas por el tipo penal y que además, el sujeto tenga el conocimiento de las circunstancias descritas por el tipo penal y que además, el sujeto tenga el conocimiento de la significación antijurídica del hecho, sea que el sujeto activo piense que al formalizar cualquier Negocio jurídico en el que encubrirá el capital del crimen esta realizando algo prohibido, sea, que el sujeto sepa que esa acción esta prohibida: es necesario además que el sujeto activo tenga la voluntad de realizar cualquier negocio jurídico con la finalidad de legitimar los recursos económicos provenientes del comercio ilícito de drogas y actividades relacionadas con él".

Al igual que todas las infracciones dolosas, en el lavado el sujeto activo en el proceso se inicia con el planteamiento, la decisión de que cometerá tal acción hasta que logra su realización. La dogmática penal ha 
visto el fenómeno anterior, en grados o etapas de la progresión criminal, que tiene su origen en el inicio de la idea criminal hasta su total ejecución. Es lo que se conoce en derecho penal sustantivo como "inter criminis". Este proceso puede dividirse en dos etapas, una interna, que se da en el seno del ánimo del autor, aquí se ve el elemento subjetivo o moral del lavado, y la fase externa, que es cuando se manifiesta en el exterior la voluntad, por ejemplo, la transferencia.

Partiendo de lo anterior podría decirse que el carácter del lavado de activos es esencialmente doloso.

La condición para que se tipifique la infracción de conocer la procedencia de los bienes, objeto de lavado de activos, es señalada como razón fundamental, con lo que la ausencia del conocimiento determina, en muchos casos, la atipicidad.

Para cumplir con el principio de culpabilidad en el lavado se requiere la conciencia y la voluntad de llevar a cabo una de las conductas típicas que como expresa Silvia Sánchez "siguiendo la postura tradicional con relación al dolo típico, este se define como el conocimiento y la voluntad de realización de los elementos objetivos del tipo de blanqueo de capitales"10. Esto quiere decir que es necesario que el dolo abarque todos los elementos objetivos del tipo, siendo los de más importancia en el crimen del lavado, según la doctrina, el objeto material y la acción típica.

Se trata de un delito doloso, no sólo en el sentido de la propia acción sino también de la acción antecedente ${ }^{11}$. El conocimiento del autor no sólo se debe referir al hecho de que interviene en la inversión o tráfico de una cosa o de un capital obtenido por otro. Como se observa a simple vista, esta es una acción del todo ilícita, que abarca, también, la acción antecedente y está comprendido el dolo eventual12, algo innecesario porque nadie hubiera dudado de ello, aun sin este añadido.

De tal manera, todos los problemas examinados antes son automáticamente trasladados al conocimiento cierto o eventual del autor de la prohibición que se analiza (favorecimiento real).

Brindemos un ejemplo: si el autor del favorecimiento conoce que el autor de la acción antecedente ha obrado al amparo de una justificación -regla de permiso específico, como sucede en el caso de aquél que comercializo con estupefacientes para conseguir dinero a fin de comprar un medicamento necesario para conservar su vida en el país, no incurre en conducta prohibida alguna si interviene, posteriormente, en el tráfico o inversión del beneficio obtenido, esto es, si requerido por el autor de la acción antecedente, que le revela todos los detalles de su obra, compra el medicamento y se lo envía.

Nótese, también, que el autor puede obrar, con error sobre la conducta del autor de la acción antecedente, v.gr., 
creer que él obró en el estado de necesidad apuntado y ello, claramente, eliminaría su punibilidad por el comportamiento, que no se acomodaría a la prohibición penal que se trata.

En resumen, la Ley No. 72-02 sobre lavado de activos provenientes del tráfico ilícito de drogas, sustancias controladas y otras infracciones graves, en su capítulo III, Sección I, describe las infracciones y determina ya desde el texto que se está en presencia de infracciones dolosas, es decir, aquellas conductas que requieren el conocimiento y la voluntad por parte del sujeto para que queden configuradas.

El legislador ha utilizado, para poder identificar las infracciones como dolosas, la palabra "a sabiendas".

Conforme al art. 3 "... incurre en lavado de activos la persona que, a sabiendas de que los bienes, fondos e instrumentos son el producto de una infracción grave: a) convierta, transfiera, transporte, adquiera, posea, tenga, utilice o administre dichos bienes...".

Como ha quedado establecido en la propia Ley, la infracción reprimida por el legislador exige que el autor realice todos o algunos de los verbos típicos y además tenga el conocimiento y la voluntad de realizarlos.

Se exige "la voluntad realizadora del tipo objetivo, guiada por el conocimiento de los elementos de éste en el caso concreto. En su conceptuación legal, más sintética...dolo es el fin de cometer un delito...".13

Conforme la descripción realizada, podríamos afirmar, que el legislador ha descrito las conductas prohibidas (infracciones) con una finalidad directa, al momento de realizar la acción, y por ello a utilizado la palabra "a sabiendas".

Lo importante, al momento de analizar el aspecto cognitivo del dolo es que todos los elementos que integran el tipo penal hayan tenido actualidad en algún momento de la etapa interna, es decir, que el sujeto haya tenido la racionalidad suficiente para lograr la finalidad típica exigida por la descripción de la conducta.

Veamos un ejemplo.

La descripción típica contenida en el art. 3 de la Ley exige el conocimiento, por parte del agente, de que los "bienes, fondos o instrumentos" sean el producto de una infracción grave.

Se trata de un conocimiento sobre las circunstancias de hecho, es decir, del origen de los fondos que el agente convierte, transfiere, transporta, adquiere, posee, etc. 
El legislador se ha referido al dolo del delito antecedente y, por ello, exige que el sujeto conozca la ilicitud de los bienes, fondos o instrumentos.

Este conocimiento sobre las circunstancias de hecho (delito antecedente) debe ser dentro de la etapa interna del sujeto, actual.

El sujeto debe conocer el origen de los bienes a sabiendas que son el producto de una infracción grave (nos referimos al delito antecedente).

Conforme ha quedado expresado en la norma que se analiza, el legislador le exige al agente (autor) no sólo el conocimiento de todos o cada uno de los verbos típicos incluidos (convertir, transferir, transportar, adquirir, poseer, tener, utilizar o administrar), sino que además conozca (a sabiendas) que los bienes, fondos e instrumentos son el producto de una infracción grave (origen de los bienes, delito antecedente).

En el ejemplo que se analiza, quien conoce que convirtiendo los bienes logrará darles apariencia lícita, también debe conocer su origen ilícito. No es suficiente que tenga el conocimiento y la intención de transferir o convertir los fondos. Tiene, además, que conocer que con esa acción logrará darles apariencia lícita. Si ello es así, entonces resultará evidente que conoce que el origen es ilícito.

Actuará con dolo el sujeto que "oculte o encubra" los bienes, fondos o instrumentos. Aparece como evidente que encubrir engloba el comportamiento de quien conoce el origen delictivo, y oculta quien tiene la finalidad de que no se conozca. Aquí parece claro que la ocultación solo se condice con el conocimiento del origen ilícito de los bienes.

La ilicitud de los bienes es, por lo tanto, uno de los requisitos del tipo objetivo, que el sujeto debe conocer para que pueda decirse que ha actuado con dolo. Para que la acción -verbo típico- sea subsumible en la conducta descrita por la norma, los bienes (transferidos, ocultados, administrados, etc.) debe ser producto de una "infracción grave" preexistente.

El conocimiento de la ilicitud de los bienes (delito antecedente) entonces integra el dolo.

Demás está decir que el sujeto deberá tener conocimiento y voluntad de realizar cada uno de los verbos típicos (manifestación del dolo stricto sensu).

Así, el sujeto, además de conocer el origen ilícito de los bienes, fondos o instrumentos tendrá que conocer y querer la realización de los verbos típicos "convertir, transferir, transportar, adquirir, etc. etc., para que quede 
configurada la infracción contemplada en el art. 3 de la Ley.

\section{Tipo subjetivo y error de tipo. Problemas particulares}

Se ha expresado: "Quien en la comisión del hecho no conoce una circunstancia que pertenece al tipo legal no actúa dolosamente". 14

Para que pueda hablarse de que se encuentra configurado el dolo, el sujeto debe conocer y querer la realización de todos y cada uno de los elementos del tipo objetivo.

Cuando el sujeto actúa bajo un error que recae sobre alguno de los elementos del tipo objetivo, se dice que se encuentran frente a un error de tipo.

Se trata del error que afecta las circunstancias de hecho.

Veamos con un ejemplo.

Si el sujeto, a sabiendas de que los bienes que posee son de origen ilícito pero tiene un error sobre la circunstancia de que los está administrando, se dirá que no hay dolo en virtud de que el sujeto tiene un error sobre uno de los elementos del tipo objetivo, que en este caso es administrar.

Existen también los casos en los que el error recae sobre la causalidad y el resultado.

El primer caso es el denominado "aberratio ictus". Se trata del supuesto en el que el sujeto quiere dirigir su acción a un objeto pero resulta afectado otro diferente al elegido, al que no se quería afectar ni aceptaba la posibilidad de hacerlo.

Veamos un ejemplo en la Ley que se está analizando.

El sujeto A posee dos cuentas bancarias en la misma entidad: cuenta 123 (cuyos fondos conoce que son el producto de una infracción grave) y la cuenta 124 (cuyos fondos también son producto de una conducta ilícita precedente).

En una oportunidad decide transferir los fondos de la cuenta 123 (incurriendo de esta manera en el lavado de activos), pero comete un error y transfiere los fondos de la cuenta 124. 
Según lo expuesto, el sujeto A ha querido dirigir su acción (transferir los fondos de la cuenta 123), pero el resultado obtenido ha afectado a otro objeto (ha transferido los fondos de la cuenta 124).

En ese caso se dirá, que la conducta del sujeto A ha quedado en grado de tentativa en virtud de que el resultado buscado (transferir los fondos de la cuenta 123) no se ha alcanzado.

Sin embargo, también debe afirmarse con relación al resultado efectivamente provocado, que existió dolo en virtud de que el mismo está abarcado por la voluntad realizadora del sujeto A (transferir fondos cuyo origen ilícito conocía incurriendo en lavado de activos).

Creemos que se trata de objetos típicamente equivalentes y por ello el error recaído sobre el objeto es irrelevante.

El otro supuesto es el denominado "dolus generalis". Se trata del caso en el que el sujeto si bien previó el resultado típico como producido por uno de sus actos parciales, dentro de todo un curso fáctico, éste deviene por un acto parcial ejecutado por él mismo.

El caso más complejo es aquél en el que el sujeto alcanza el resultado en un segundo acto, es decir, cuando ya creía haberlo logrado.

En nuestro ejemplo, el sujeto A cree que ha transferido los fondos y, para ocultar la transferencia, realiza un depósito cuyo destino es la misma cuenta a la que en principio realizaría la transferencia y donde efectivamente se han desviado los fondos, incurriendo el sujeto $\mathrm{A}$ en lavado de activos.

Si entendemos que existe una sola conducta, ésta está abarcada por el dolus generalis y, en consecuencia, el sujeto A ha cometido la infracción prevista en el art. 3, apartado a) de la Ley en análisis.

Es necesario afirmar que no se debe confundir el error de tipo, es decir, el error que recae sobre los elementos objetivos del tipo con el error de prohibición que es aquél que recae sobre el conocimiento de la antijuridicidad.

En el análisis que se está efectuando solamente importará el error de tipo, puesto que el error sobre el conocimiento de la antijuridicidad pertenece a la culpabilidad, un estrato diferente dentro de la teoría del delito.

En cuanto a los efectos del error de tipo, éste elimina el dolo en los casos de errores invencibles, pero si el error es de aquellos vencibles podrá quedar subsistente la tipicidad culposa solamente en los casos que la conducta esté prevista como tal. 
Como ya ha quedado demostrado, en todas las descripciones de la presente Ley se está en presencia de infracciones dolosas.

Finalmente, en el caso hipotético que el autor de la infracción padezca una incapacidad psíquica, es decir, una patología que le impida reconocer los elementos del tipo objetivo, se dirá que la conducta realizada por el agente es atípica.

\section{Situaciones que agravan la punibilidad: el artículo 21 de la Ley 72-02}

El artículo 21 de la ley 72-02, con una técnica legislativa muy discutible establece un conjunto de circunstancias agravantes, entre las que se encuentran: la participación en grupos criminales, el haber cometido el hecho en asociación de dos o más personas, cuando el autor hubiese ingresado al territorio nacional sin autorización o ilegalmente, cuando fuese funcionario público, cuando fuese reincidente, o en los casos de empleos de menores. Ahora bien, lo que lejos está de ser claro es la consecuencia normativa precisa de estos agravantes, teniendo en cuenta que el artículo 21 establece que en estos casos los autores caerán bajo la esfera del los artículos 56, 57 y 58 del Código Penal. Sin embargo, estas tres normas se refieren en forma exclusiva a la reincidencia y a sus consecuencias punitivas. Una lectura más o menos razonable tendría que concluir que en los casos de estos agravantes, el autor será tratado con el régimen de la reincidencia, más allá, de que efectivamente, en los hechos, haya habido tal recaída en el delito. Llama la atención esta remisión, de todos modos, ya que el propio artículo 21 incluye como agravante a la misma reincidencia. Sin duda hubiera sido preferible que, una vez estipuladas las circunstancias agravantes que el legislador ha querido remarcar, se defina una fórmula sencilla de aumento de pena. 
1 Blanco Cordero, Isidoro. El delito de blanqueo de capitales. Barcelona editorial Aranzadi SA, ISDN 84-8193-534-4

2 Arzeno, Lara, y de la Rocha, llona. La responsabilidad de la banca en el lavado de dinero, Santo Domingo, Impresión Amigo del Hogar, 1996.

3 Manual de Apoyo para la Tipificación del Delito de Lavado, elaborado por la Comisión Interamericana para el Control del Abuso de Drogas (CICAD).

4 Horacio Catanni. Jornada interparlamentaria sobre lavado de dinero.

5 Diccionario Jurídico Elemental, 1998 Editora Heliasta

6 El Vocabulario Jurídico de Henry Capitant, Ediciones de Palma, Buenos Aires.

7 Cattani, Horacio.

8 Ibídem.

9 Conde Pumpido, encubrimiento y resectación.

10 El derecho penal bancario en España, 1995.

11 "Uno de los problemas que suele plantearse con mayor frecuencia, y que tiene una gran importancia práctica, es la prueba de este conocimiento por el sujeto. Como cualquier otro elemento de los elementos que integran el ámbito de lo interno de la persona, éste solamente podrá manifestarse a través de elementos y circunstancias del comportamiento externo del que pueda indicirse dicho conocimiento. A este respecto es curioso señalar cómo tanto la Convención de Viena como la Directiva 91/308/CEE hacen específica referencia a que tanto el conocimiento, la intención o la motivación que tienen que ser elementos de las actividades ilícitas de blanqueo podrán inferirse de las circunstancias objetivas del caso".

Daniel Álvarez Pastor-Fernando Eguidazu Palacios, "La prevención del blanqueo de capitales", Aranzadi, Plamplona, España, 1998, pág. 284.

12 En la dogmática penal actual no es sencillo determinar el alcance del dolo eventual.

13 Zaffaroni, Eugenio Raúl. Tratado de derecho penal. Parte General. III, Editorial Ediar. Buenos Aires, octubre de 1987, página 295 y 296; y Roxin, Claus. Derecho Penal, Parte general, Tomo I. Fundamentos. La estructura de la teoría del delito. Editorial Civitas SA, 1997, página 415.

14 Roxin, ob. cit, página 458. 


\section{4 \\ PROBLEMAS ESPECIALES DE PARTE GENERAL EN LA INTERPRETACIÓN DEL LAVADO DE ACTIVOS}

Maximiliano Rusconi

\section{Algunas consideraciones específicas con relación a los tipos penales del lavado de activos}

El problema de lo que se ha definido como "aquella operación a través de la cual el dinero de origen siempre ilícito (procedente de delitos que revisten especial gravedad) es invertido, ocultado, sustituido o transformado y restituido a los circuitos económico-financiero legales, incorporándose a cualquier tipo de negocio como si se hubiera obtenido en forma lícita" ya se ha instalado como preocupación internacional de total trascendencia desde documentos multilaterales de la importancia de la Convención de Viena de 1988, el documento del Consejo de Europa del 8.11.1988 sobre el tema, la Declaración de Principios de Basilea del 12.12.1988 y la Convención de Estrasburgo de 1990.

Esta preocupación internacional se manifestó incluso de una forma que refleja lo que se ha denominado una "carrera asombrosa"2, teniendo en cuenta que hace dos décadas el problema del banqueo de capitales era prácticamente desconocido y que en la actualidad aparece como una temática no sólo trascendente desde el punto de vista jurídico o político criminal sino también desde las agendas político-institucionales por lo menos de los países de la región.

Sin embargo, como se ha visto, y por imperio de las reacciones estatales en cadena procurando evitar la condena internacional3, también el sector privado ha comenzado a asumir el asunto. 
Los ejemplos abundan: "Los principios de Wolfsberg contra el lavado de dinero", que detallan el acuerdo alcanzado por un importante grupo de bancos privados (asistidos por un equipo de Transparency International, al cuál se incorporaron los expertos Stanley Morris y Prof. Mark Pieth) en el sentido de estipular un modelo consensuado de prevención del lavado de capitales, es una de las muestras de la última década.

Allí se establecieron lineamientos que se ocupan de temas como: identificación de clientes, de beneficiarios y/o usufructuarios de cuentas; realización de estudios sobre administradores monetarios; evaluación técnica (due diligence) para la apertura de cuentas; exigencias de conocimiento fidedigno del cliente para los casos de cuentas numeradas; procedimientos especiales para países y actividades de "alo riesgo"; verificación minuciosa para funcionarios públicos; actualización de archivos de clientes; determinación de actividades sospechosas (a-transacción de la cuenta u otras actividades que no resultan consistentes con los datos recopilados en la evaluación técnica, b- transacciones en efectivo por encima de cierta suma, c- transacciones "de paso" que entran y salen); determinación de mecanismos para detectar actividades sospechosas (monitoreo de transacciones, contactos con el cliente, información de terceros, conocimiento interno del banquero privado sobre el entorno del cliente); determinación de las acciones a seguir en caso de identificar una actividad inusual (monitoreo más intenso, cancelación de la relación comercial, información de la relación comercial a las autoridades); desarrollo de modelos de monitoreo y control, desarrollo de programas de educación; capacitación e información; y establecimiento de departamentos especiales para la prevención del lavado (compliance officer).

La preocupación de la banca privada es razonable con sólo pensar en algunos de los ejemplos internacionales: en el Reino Unido, el mayor poder dado en los últimos años al Financial Services Authority -FSA- ha implicado la amonestación de muchos bancos por sus débiles medidas de prevención del lavado en la recepción de fondos.

Por otro lado, se ha llegado incluso a emitir una "libreta de calificaciones" realizada anualmente por el GAFI entre las naciones y organizaciones que lo integran, en la cual se evalúa el cumplimiento de los países a las recomendaciones que realiza la institución en materia legal y financiera.

Pero, si en verdad existe disposición a evitar tomar el atajo de los discursos de emergencia habría que contrarrestar uno de sus golpes maestros: justamente nunca abordar con absoluta precisión la determinación de cuál será la conducta que en definitiva legitimará la manifestación del poder penal del Estado o por lo menos no reconocer todos los problemas sistemáticos, político-criminales y constitucionales de cada una de las posibles redacciones de cuál es la conducta que en definitiva va a estar alcanzada por la norma.

Esta discusión muchas veces se oculta detrás del repaso de los instrumentos de eficiencia que deberían girar 
en forma satelital alrededor de este análisis que, a nuestro juicio, le precede en el orden temporal y, posiblemente, de importancia.

No cabe duda que es más apasionante el debate sobre los distintos modelos de cooperación internacional, 0 el modo como se integran las unidades de inteligencia o información financiera, o el papel de las distintas instituciones en el control estatal de estas conductas.

Pero en algún momento debería discutirse con alguna seriedad todos los inconvenientes propios de la misma redacción del tipo penal del "lavado de capitales".

Para que quede claro: más allá de los avances legislativos y/o político criminales, es necesario proponer el desarrollo de una verdadera dogmática de la interpretación del delito de lavado de dinero, que permita mejorar las técnicas hermenéuticas de quienes en definitiva son los que deben llevar la subsunción de la norma a los casos concretos: los jueces.

Parte de eso se trata en este capítulo.

\section{Cuestiones dogmáticas específicas del ilícito de lavado de activos en la Ley 72-02}

Es preciso afirmar, como seguramente ya debe haber sido intuido en los capítulos anteriores, que los artículos 3 y 4 de la ley 72-02 de la República Dominicana esconden una buena cantidad de problemas dogmáticos que deben ser analizados con cuidado a efectos de no cometer errores en su interpretación, debido a que son estos artículos los que definen las principales acciones reprimidas por esta ley.

Los restantes artículos que la componen, como vimos, contienen definiciones, el objeto de la ley, reprimen conductas omisivas y especifican penas, tanto para hechos consumados como para hechos tentados.

La relación de lo contenido en estas normas con los problemas fundamentales de la parte general genera la necesidad de algunas precisiones en materia de autoría y participación, tentativa, relaciones concursales, etc.

Sin embargo, y más allá del análisis que ya se ha realizado del contenido fundamental de las normas mencionadas, es preciso remarcar algunos problemas interpretativos que pueden dar lugar a la discusión 0 generar dudas en la definición del alcance de lo prohibido. 


\section{1. Problemas a resaltar en la redacción del artículo 3 de la ley 72-02}

El artículo tercero define, como ya se ha visto, el llamado "lavado de activos" en los siguientes términos: "... incurre en lavado de activos la persona que, a sabiendas de que los bienes, fondos e instrumentos son el producto de una infracción grave:

Convierta, transfiera, transporte, adquiera, posea, tenga, utilice o administre dichos bienes;

Oculte, encubra o impida la determinación real, la naturaleza, el origen, la ubicación, el destino, el movimiento o la propiedad de dichos bienes o de derechos relativos a tales bienes;

Se asocie, otorgue asistencia, incite, facilite, asesore en la comisión de alguna de las infracciones tipificadas en este artículo, así como el eludir las consecuencias jurídicas de sus acciones".

Las normas jurídico-penales describen conductas humanas jurídicamente relevantes. Tienen -o deberían teneruna naturaleza eminentemente descriptiva. La definición de la conducta es lo que se ha dado en llamar la tipicidad. Como es sabido, la tipicidad (primer nivel de subsunción en el proceso hermenéutico judicial) no es otra cosa que la descripción de la materia de prohibición. Las definiciones de las acciones, se encuentran ubicadas en los verbos típicos.

En los delitos dolosos de comisión, como el que se analizará, el aspecto externo de la conducta es lo que se Ilama el tipo objetivo. Es la manifestación de la voluntad requerida por el tipo4.

Por lo tanto, la descripción del tipo penal debe comenzar por la adecuación típica de ese aspecto externo, que se manifiesta a través de las acciones o verbos típicos.

El párrafo a) contiene ocho conductas (verbos): convertir, transferir, transportar, adquirir, poseer, tener, utilizar o administrar bienes que sean producto de una infracción grave.

La conjunción "o" que utiliza este inciso denota que el tipo objetivo describe conductas independientes entre sí. Es decir que comete este delito, por ejemplo, tanto quien administra como quien convierte, sin necesidad de que todas o más de una de estas acciones se verifiquen en el caso. Si se verifica la comisión de más de una de estas acciones -v.gr. administrar y utilizar- no nos encontraremos ante una relación de concurso de leyes (posiblemente ideal, si es que se ha realizado mediante una sola acción o real si estos verbos se han realizado a través de procesos ejecutivos autónomos), pues se trata de una misma ley que define varias acciones posibles de modo alternativo, todas ellas típicas. 
El tipo penal que aquí se analiza se encuentra subdividido en tres apartados. Esta subdivisión no es caprichosa. Se trata de una técnica legislativa tendiente a su mejor comprensión de las distintas categorías de conductas. Las conductas contenidas en el apartado a) quizás a excepción de los términos "convertir" y "transferir" se refieren al contacto con el producido de los ilícitos y se han definido sin tener en mira la participación activa en dificultar o impedir la determinación de su origen. El agente conoce el origen de los bienes y toma contacto con ellos, ya a través de su transporte, ya a través de su posesión, tenencia o administración. Pero no intenta, específicamente, el ocultamiento del delito precedente, tal como lo define la naturaleza de las conductas expuestas en el inciso siguiente.

La descripción de cada uno de los verbos típicos no implica, en sí misma, el fin de que se desconozca el origen de los bienes. Quien adquiere, posee, tiene, utiliza o administra, disfruta o toma contacto con ese producido no significa que tienda al despiste u ocultamiento de la ruta del producido del ilícito. El significado de cada uno de estos verbos -quizá a excepción de quien convierte o transfiere- no trae aparejado, en sí mismo, una conducta de ocultamiento, aunque sí - con alguna licencia terminológica- de disfrute o utilización.

Por el contrario, convertir y transferir aparece sustancialmente identificado a una acción de transformación u ocultamiento del producido del ilícito, por lo que posiblemente hubiera resultado conveniente ubicarlo en el segundo párrafo. Para la Real Academia Española, convertir significa "hacer que alguien o algo se transforme en algo distinto de lo que era... La piedra se ha convertido en polvo..."5. Transferir significa "pasar o llevar algo de un lugar a otro... Operación por la que se transfiere dinero de una cuenta bancaria a otra"6. Se advierte de estas definiciones que la naturaleza de la acción parece conllevar implícita la consecuencia del ocultamiento de los bienes que son producto de la infracción grave.

Veamos cada una del resto de las acciones definidas en este inciso y sus definiciones lingüísticas, para conocer, con precisión, qué es lo que la ley describe.

Transportar es, según la fuente ya citada, "llevar a alguien o algo de un lugar a otro"7; adquirir consiste en "ganar, conseguir con el propio trabajo o industria, coger, lograr o conseguir"8; poseer es "tener en su poder algo... tener una cosa o ejercer una facultad con independencia que se tenga o no derecho a ella" 9 ; tener implica poseer10, utilizar significa "aprovecharse de algo"11 y, finalmente, administrar es, en su acepción más aplicable, "ordenar, disponer, organizar, en especial, la hacienda de los bienes".

Se advierte que entre los dos primeros verbos típicos - convertir y transferir- y los últimos, existe una notoria diferencia. Las definiciones de las acciones de los dos primeros, se encuentran sustancialmente identificadas con el ocultamiento de los bienes provenientes del delito precedente. Quien convierte o transfiere, sí modifica la ruta causal o natural del producto del ilícito. No sólo toma contacto con ellos, sino que parece difícil 
independizar su actividad de una maniobra tendiente a impedir la "determinación real, naturaleza, origen, ubicación o destino de los bienes", acciones definidas en el párrafo b). Parecería que quien convierte bienes, oculta la determinación real de ellos -o al menos la dificulta-. Es por ello, que se entiende que posiblemente estas acciones se encuentren más identificadas con las acciones prohibidas en el segundo párrafo.

Es claro que cualquiera de las acciones definidas en este inciso puede encubrir, ocultar o impedir la determinación de los bienes. Lo que se intenta explicar es que difícilmente quien convierte bienes -conociendo su origen ilícito no esté impidiendo su determinación real.

El párrafo b) define tres acciones: ocultar, encubrir o impedir. La primera pregunta que surge es qué es lo que se requiere para que se oculte, encubra o impida: la determinación real, la naturaleza, el origen, la ubicación, el destino, el movimiento o la propiedad de dichos bienes o de derechos relativos a tales bienes.

De acuerdo con esta descripción sería factible, por ejemplo, impedir la determinación real, la naturaleza, el origen, la ubicación, el destino, el movimiento o la propiedad de los bienes o derechos relativos a ellos. Sin embargo, ello no parece posible. La naturaleza o el origen de los bienes, puede ocultarse, pero no impedirse.

Consecuentemente, se entiende que el tipo penal bajo análisis se refiere, en realidad al que oculte, encubra 0 impida la determinación real, de la naturaleza, del destino, del movimiento o de la propiedad de los bienes.

Una operación lógica lleva a esta conclusión. Al resultar imposible conjugar algún verbo típico con el predicado, se arriba a la evidente conclusión de que lo que se oculta, encubre o impide es siempre la determinación de alguna de las características del bien. Es decir, no se oculta el movimiento sino la determinación del movimiento; no se impide la propiedad, sino la determinación de la propiedad.

Es claro que las acciones típicas de este inciso establecen una relación con el objeto del delito, siempre tendiente a dificultar o imposibilitar la determinación de dichos bienes. Aquí aparece bastante clara la diferencia legislativa entre el primer apartado de este artículo y el que se está analizando.

Más allá de que cada acción típica debe ser conjugada con el predicado e incluye la determinación, los términos, por sí mismos, definen la acción como de una naturaleza que dificulta o imposibilita.

El significado semántico, otra vez, apoyará esta idea. Ocultar significa "esconder, tapar, disfrazar, encubrir a la vista. Callar advertidamente lo que se pudiera o debiera decir, o disfrazar la verdad"12. Encubrir, es, "ocultar algo o no manifestarlo. Impedir que llegue a saberse algo. Hacerse responsable del encubrimiento de un delito". 
Por otro lado, las conductas definidas en el apartado c) hacen referencia directa o para ser más claros, remiten a todas las infracciones tipificadas en los primeros dos apartados. No define nuevas conductas, sino que intenta señalar -o modificar- específicas reglas de autoría y participación, equiparando cualquier clase de participación en la comisión del ilícito a la categoría de autor de una conducta accesoria del ilícito principal.

\subsection{El incremento patrimonial no justificado y el artículo 4 de la Ley 72-02}

El artículo 4 de la ley establece lo siguiente:

"El conocimiento, la intención o la finalidad requeridos como elementos de cualesquiera de las infracciones previstas en esta sección, así como en los casos de incremento patrimonial derivado de actividad delictiva consignada en esta Ley, podría inferirse de las circunstancias objetivas del caso.

Párrafo: Las personas cuyos bienes o activos se vinculen a la violación de esta Ley, siempre que no puedan justificar el origen lícito de los mismos, serán sancionadas con las penas establecidas en la misma".

Entendemos que, además de las críticas que merece la construcción jurídica que intenta desarrollar este artículo, existe un claro problema de redacción, lo que dificulta la correcta comprensión de la Ley.

El conocimiento, la intención o la finalidad requeridos para la configuración de las acciones previstas en la Ley pueden ser inferidos de las circunstancias objetivas del caso. Esta es una primera conclusión que luego será analizada jurídicamente.

Por otro lado, la Ley parece explicar que el conocimiento, la intención o la finalidad requeridos en los casos de incremento patrimonial derivado de actividad delictiva consignada en esta ley, también podría inferirse de las circunstancias objetivas del caso.

En definitiva, la Ley está consignando una obviedad. Siempre, en todos los casos, sus circunstancias objetivas serán valoradas a la luz de la sana crítica racional. Sin embargo, las circunstancias objetivas definen la tipicidad del hecho y no la prueba del dolo. Evidentemente, el legislador influye sobre la discrecionalidad del juez a los efectos de que éste encuentre la posibilidad de inferir el dolo -en términos de conocimiento, intención y finalidad- en la tipicidad objetiva. Esta presunción es avasallante del sistema de valoración probatorio al que se someten las conclusiones judiciales y en las cuales se debe certificar la existencia de todos los elementos constitutivos del delito y la inexistencia de causas de justificación, inculpabilidad y no punibilidad.

En otras palabras, las conclusiones judiciales, para la obtención de una condena, deben acreditar que el hecho 
existió, que es típico objetivamente, subjetivamente, antijurídico, culpable y punible. No puede inferirse, por un mandato del legislador, que la acción es dolosa. Ello debe comprobarse judicialmente a la luz del sistema de valoración probatorio pertinente. Esta es una actividad reservada a la actividad jurisdiccional -por imperio de la división de poderes- y no puede -o no debe- prescindirse por un mandato legislativo ex ante.

El párrafo siguiente crea una presunción de culpabilidad contra el justiciable, contraria al estado de inocencia que debe ser destruido por el Estado. El Principio de inocencia, introducido con claridad por primera vez con la Declaración de los Derechos del Hombre y del Ciudadano ${ }^{13}$ es un pilar fundamental en el proceso judicial. La regulación normativa de este Principio indica que la carga probatoria le corresponde al Estado, que es quien, en definitiva, lleva el peso de obtener una condena contra quien atentó contra los bienes jurídicos que éste ha decidido proteger.

Resulta interesante realizar una breve reseña de lo sucedido en la Argentina en torno a la discusión sobre el artículo 2682 del Código Penal, pues se trata de un tipo penal de enriquecimiento ilícito, donde ocurre una inversión de la carga idéntica a la que aquí se propone, con la única diferencia de que el delito se encuentra previsto para los funcionarios y empleados públicos. Sobre este tema, señaló Fontán Balestra: "Ninguno de los argumentos tendientes a demostrar que la prueba no se invierte nos convence. Porque, en definitiva, lo que se debe demostrar es que el enriquecimiento no es ilícito, o si se quiere, que es lícito; que proviene de fuentes que no se vinculan directamente con la función pública y que no es merecedor de reproche"14.

Sancinetti, que más ha atacado la constitucionalidad de este artículo, ha escrito: "Normalmente se le critica al texto... el invertir la carga de la prueba al pone al imputado en la obligación de acreditar su inocencia, en lugar de que el estado tenga que probar su culpabilidad. Esta fue una de las razones dadas en diputados para decir que el delito era inconstitucional: la violación manifiesta al principio de inocencia". ${ }^{15}$

Esta idea de la carga probatoria estatal como consecuencia normativa del Principio de Inocencia ha sido discutida en rededor al delito de enriquecimiento ilícito de funcionarios y empleados estatales. En este sentido se ha afirmado que en estos casos de "enriquecimiento ilícito" el carácter de funcionario público lo coloca en una situación sujeta a un mayor control de sus actividades y patrimonio, reduciendo su ámbito de protección constitucional en virtud del poder y la exposición que su representatividad genera. En resumen, se ha dicho que "el resto de la doctrina y especialmente la jurisprudencia oscila entre no responder a los planteos de inconstitucionalidad (...) por un lado; y el reconocimiento de la que la figura puede llegar a reñir con la Constitución, pero que sin embargo, o existen otros principios más importantes, o tales pautas constitucionales no pueden ser invocadas en el caso en atención a la categoría de personas a las que está dirigida la norma (funcionarios públicos) por el otro".16 
El argumento destacado, quizá sustentable sólo en el caso de los funcionarios públicos, no parece trasladable al ámbito de los particulares, pues la protección que genera el principio de inocencia se encuentra especialmente dirigida a ellos como valla al monopolio del poder estatal.

En definitiva, si bien existen opiniones encontradas acerca de la constitucionalidad de la inversión de la carga de la prueba en los casos de funcionarios públicos, entendemos que si no se trata de funcionarios públicos, no hay posibilidad alguna de entender constitucional un tipo penal que exige a los particulares que demuestren su inocencia.

\section{Autoría y participación en lavado de capitales}

\section{1. La definición del autor. El modelo legislativo}

Habitualmente, como se verá, los códigos penales hispanoamericanos contienen reglas de autoría y participación, en las que se definen y diferencian los alcances de la responsabilidad penal de los autores, respecto de los partícipes e instigadores. Por ejemplo, el autor de un delito, merece una pena superior a la que le corresponde a un partícipe secundario. Esta es, sin lugar a dudas, una decisión político criminal, que no por ello deja de ser compleja en la medida en que se trata de reglas que intentan definir distintos niveles de "gravedad" en la acción llevada a cabo.

El Código Penal de República Dominicana, como se sabe, ha optado por un claro modelo de diferenciación de estos niveles de gravedad. Es así como el artículo 59 afirma que a los cómplices se les impondrá una pena inmediatamente inferior a la que le corresponde al autor. Sin embargo, posibilita que las diferentes legislaciones especiales dispongan un modelo contrario: "salvo los casos en que la ley otra cosa disponga", dice textualmente la norma. En otras palabras, se trata de una suerte "medida dogmática" de la lesión al bien jurídico tutelado.

Para esa concepción clásica no lesiona del mismo modo quien administra los bienes -producto de una infracción grave- que quien le presta asesoramiento. De ahí la diferenciación entre los distintos niveles de participación en la comisión de un ilícito.

Históricamente se ha desarrollado, a ese respecto, un conjunto de teorías de la autoría que pueden ser clasificadas en forma sencilla del siguiente modo: a) formal-objetiva; b) material-objetiva y c) subjetiva. De acuerdo a la teoría formal-objetiva, posiblemente dominante en el primer tercio del presente siglo (aunque ya abandonada en Alemania, por ejemplo), es autor quien ha realizado en forma directa la acción descripta en el 
verbo típico. En alguna medida se ha tratado de respetar en forma excluyente la sujeción a las palabras de los tipos de la parte especial. Esta teoría que ya tuviera defensores, aparentemente, en el S. XIX fue defendida por autores de gran renombre (Ernst Von Beling y Max Ernst Mayer, entre otros) y mantiene algo de lozanía, todavía, en nuestra región. La crítica de Bacigalupo a esta tesis es absolutamente correcta: "del tomar parte no es posible deducir todavía quién es autor y quién es cómplice o cooperador".

La concepción objetivo-formal de la autoría prescinde en forma absoluta de la trascendencia de la contribución al hecho en el contexto de todo el suceso típico (quizá, por su visible adscripción al criterio causal, dominante en la época de su surgimiento). Sólo toma en cuenta las respectivas descripciones de los tipos penales involucrados en la definición normativa del supuesto de hecho.

Como se ha dicho, uno de los puntos en los cuales la teoría manifiesta su incapacidad se relaciona con los tipos penales puros de resultado en los que, justamente, se carece de una descripción del suceso ilícito.

Por otro lado, es indudable que la teoría objetivo-formal sólo reconoce una capacidad de rendimiento admisible en los supuestos de delitos de propia mano y se manifiesta como insuficiente en todos aquellos casos en los cuales el autor de propia mano no es quien verdaderamente domina las riendas del hecho ilícito -quizá, incluso, por falta de dolo- y es conducido por un hombre que se encuentra detrás (autoría mediata). Es claro que la posibilidad, hoy admitida por la doctrina y la jurisprudencia mayoritarias, de que se considere autor a quien utiliza como instrumento a un inimputable, o un sujeto que actúa con error de prohibición, o en el marco de un estado de necesidad disculpante, pone en verdadera crisis la base de sustentación de la teoría formalobjetiva.

La teoría subjetiva es la consecuencia científica del reconocimiento de alguna imposibilidad para distinguir, ya en el plano objetivo, los diferentes roles de los partícipes en el ámbito de la ejecución de un determinado supuesto de hecho típico. Si todos los aportes al hecho son igualmente causales, entonces no es posible distinguir entre ellos algún dato diferenciador. Es por ello que la teoría subjetiva acude a la pregunta de para quién quiere el hecho el partícipe (lato sensu). Para decirlo con palabras de Maurach/Gössel/Zipf17 "es coautor quien quiera como propio el hecho común, es decir, quien actúe con animus auctoris, el cual reemplaza absolutamente a la potestas autoris. Al contrario, es cómplice aquel que quiere como ajeno el hecho en el cual colabora $y$, en consecuencia, manifiesta meramente un más débil animus socci". Esta teoría pretende solucionar las exigencias de la teoría formal-objetiva, posibilitando la imputación del hecho como autora (en un caso de la jurisprudencia alemana muy conocido) a la madre que luego de dar a luz solicita a la hermana que ahogue en la bañera al hijo recién nacido. 
la doctrina dominante en forma bastante clara: básicamente se debilita la función de garantía de la ley penal, ya que el ámbito de lo prohibido no se vincula al tipo de acción desplegada en el mundo real sino a qué valor le atribuye el "autor" a sus propios actos.

Los últimos 25 años han estado dominados por las teorías material-objetivas de la autoría, sobre todo a través de la expresión consistente en la doctrina del dominio del hecho impulsada modernamente por Claus Roxín, aunque reconociendo su origen en los trabajos de Lobe en la década de los treinta.

Autor es, para esta teoría, alguien a quien le puede ser imputado el tener las riendas del suceso. Es autor quien protagoniza la conducción final del suceso o del acontecer típico. Desde este punto de vista, sale del eje central de imputación todo aquello que no pueda ser visto como la determinación fundamental del sí y el cómo del suceso típico.

El nacimiento de esta teoría se encuentra históricamente vinculado a la búsqueda de precisas y determinadas consecuencias político-criminales, entre ellas, la limitación de los excesos provenientes de la teoría subjetiva y, más modernamente, la posibilidad de desvincular a la imputación de autoría de su cercanía causal con la lesión del bien jurídico o la producción del resultado. Esta posibilidad plantea un entorno normativo muy amigable para el desarrollo paralelo de la teoría del dominio del hecho en el ámbito de la autoría y participación y de la teoría de la imputación objetiva en el ámbito de la tipicidad.

La teoría del dominio del hecho permite, asimismo independizar al funcionamiento de las reglas de la imputación de distintos roles en el ilícito de las palabras que haya elegido el legislador para definir la conducta prohibida. A través de esta teoría se ofrece una explicación permanente y no variable del ilícito.

Una de las discusiones modernas sobre esta cuestión se vincula con la capacidad de respuesta de la teoría para la totalidad de las formas de ilicitud. Algunos autores entienden que "el dominio del hecho es un elemento objetivo necesario de autoría en los hechos punibles dolosos en todas sus formas"18. Otros autores, sin embargo, distinguen en delitos de violación de un deber y delitos de dominio (Roxín) o de organización (Jakobs).

Desde el prisma de la distinción entre delitos de infracción de un deber y los de dominio, los primeros se caracterizan en que el papel del autor es explicable en forma total por la infracción de un deber específico dirigido al agente. En los delitos de infracción a un deber no se trata ya de que el autor sea quien domina el hecho desde el punto de vista material, sino de que el ámbito del destino de la norma se encuentra particularmente circunscrito (delitos especiales y delitos de omisión). 
Según un autor, "el elemento que... decide sobre la autoría constituye una infracción de un deber extrapenal que no se extiende necesariamente a todos los implicados en el delito, pero que es necesaria para la realización del tipo. Se trata siempre de deberes que están antepuestos en el plano lógico a la norma y que, por lo general, se originan en otras ramas jurídicas. Ejemplos de esta categoría son los...deberes jurídico-públicos de los funcionarios, los mandatos de sigilo en ciertas profesiones o estados y las obligaciones jurídicos-civiles de satisfacer alimentos y de lealtad. Todos ellos se caracterizan porque el obligado sobresale entre los demás cooperadores por una especial relación con el contenido de injusto del hecho y porque el legislador los considera como figura central del suceso de la acción, como autores, precisamente debido a esta obligación”19.

De un modo u otro, y más allá de las ventajas político-criminales de la distinción, es dudoso que el concepto del "dominio del hecho" no hubiera tenido, con algunas modificaciones previsibles, la capacidad explicativa para dar respuestas razonables también a estos casos.

La clave hermenéutica del dominio del hecho alude al desarrollo de un modelo de imputación absolutamente normativo y ello garantizaba desde el comienzo la legitimidad de incluir entre los criterios que definen la atribución a la cuenta del autor de incumplimientos de deberes que surgen de una relación similar a una "garantía". Nuevamente se trata de definir el fin de la norma como criterio no negativo sino positivo de la imputación.

La percepción de la estructura de ilicitud que enmarca a los delitos de infracción de un deber tiene en Jakobs un punto de vista distinto; ello es el resultado aparentemente de su especial explicación del sistema del hecho punible que prescinde -por lo menos en parte- de la distinción entre omisiones y acciones y coloca el problema sobre la frontera que divide a los deberes que surgen de la organización de la intervención del autor y los que nacen de su posición institucional.

Según el profesor de Bonn, "hay delitos en los que determinadas personas tienen que responder de la existencia de un bien y no sólo de que la propia organización no afecte a un bien, menoscabándolo (delitos de infracción de deber). En estos casos, la relación del interviniente con el bien es siempre directa, es decir, sin mediación accesoria, o sea, por su parte siempre en concepto de autor, y además sin tener en cuenta en absoluto un hacer. El interviniente es al menos autor por omisión y, en caso de aportación mediante hacer, por incidental que sea, autor por comisión; la distinción entre comisión y omisión pierde, pues, su sentido. Entre los delitos de infracción de deber se cuentan todos los delitos cuyos autores están obligados, en tanto que garantes, a la tutela, institucionalmente asegurada de un bien"20

Las sanciones jurídico-penales deben guardar una relación racional con la acción desplegada por el imputado. Para ello es necesario evaluar jurídico-penalmente su acción. 
En lo que respecta a la definición del concepto de autor en el ámbito de los hechos descriptos en la ley de lavado es claro que habrá que acudir, a efectos de no transformar a la ley 72-02 en letra muerta, al producto de las tesis material-objetivas: será autor quien lleve las riendas del hecho que culmina en la legitimación de los activos sometidos a estudio. Pero teniendo en cuenta que estos tipos de delitos en muchas ocasiones son realizados por grandes estructuras criminales y/o financieras es preciso que se vea en el autor a alguien que no necesariamente ha realizado un segmento lesivo de "propia mano", sino que puede haber conducido las riendas del hecho ilícito sin haber "bajado" a la participación física directa. Autor es el que conduce el hecho, quien "domina" en el sentido institucional.

La Ley de lavado (72-02) ha creado un tipo penal especial "de participación" con el artículo 3ero, inciso "C", que contiene dos problemas principales: en primer lugar, no define conductas, sino que define distintos modos de vinculación con el hecho. Se realiza aquí una ficción jurídica del siguiente modo: quien, por ejemplo, incita a la ejecución del hecho, no es un partícipe o instigador -creador del dolo- sino que resulta un autor de la incitación como si esta fuera una nueva conducta punible. La conducta punible y principal es la acción realizada -en algunos de los primeros dos apartados- y no la incitación a realizar la acción. El acto que se juzga está definido en los dos primeros párrafos, luego, para evitar confusiones quizá hubiera sido preferible someterse a las reglas de la accesoriedad para determinar su participación y no su autoría de participación.

Sin embargo, las consecuencias perjudiciales de esta política en cuanto a sus sanciones se encuentran bastante acotadas por el artículo 19. Allí se expone que la persona que incurra en la infracción de lavado de activos prevista en la letra c) del artículo 3 de la Ley será condenada a una pena de reclusión no menos de tres años ni mayor de diez y una multa no menor de cincuenta salarios mínimos ni mayor de cien salarios mínimos. Si bien el margen de sanción es enorme, el párrafo siguiente establece, aunque con poca claridad, que quien incite, facilite o asesore en la comisión de alguna de las infracciones señaladas en la ley, será condenado a la pena inmediatamente inferior aplicable a su autor principal. Queda por definirse o no se comprende, cuál es la pena inmediatamente inferior, aunque ha quedado claro, de la interpretación de este artículo, que no puede igualar la pena del autor y que no puede superar los diez años. Ello guarda racionalidad, aunque con demasiada amplitud en cuanto a sus márgenes, con el problema de la determinación judicial de la pena. Como expresa claramente Patricia Ziffer "aún cuando las reglas de la autoría y la participación permitan imputar el delito en común, es posible hacer distinciones en cuanto a la intervención efectiva que le cupo a cada uno de los partícipes según el rol efectivamente desempeñado durante el hecho... como regla general, el ilícito del autor, es más grave que el del partícipe" y continúa afirmando que "será decisivo, en todo caso, determinar concretamente cuál fue el aporte al hecho de cada uno de los intervinientes".21 


\subsection{El autor mediato en la dogmática penal y el autor mediato en la ley 72-02}

Otro problema que merece destacarse es el que genera el concepto de autoría mediata, no tratado por el apartado tercero del artículo 3. "Se trata de los supuestos en los cuales el sujeto domina la ejecución del suceso pero no lo ejecuta de propia mano, sino a través de un instrumento que por alguna razón no puede responder penalmente (falta de acción, falta de dolo, justificación, inculpabilidad, etcétera)".22

Si bien parece complejo que la ejecución del lavado de activos se realice a través de un sujeto sin acción 0 inculpable -por tratarse de un delito complejo que usualmente requiere de operaciones financieras llevadas a cabo por ejecutores calificados, sí parece probable o más bien posible que el autor mediato la realice a través de un sujeto con falta de dolo -y tal vez con un sujeto que obra justificado. Tratándose de un delito doloso, por lo tanto, el sujeto que tiene relación directa con él quedará impune, pues este tipo penal no admite la forma culposa. 23

En esos casos, el autor mediato genera el dominio del hecho a través de la utilización de un instrumento que incurre en un error de tipo y que por ello, a pesar de ejecutar directamente el suceso, no tiene capacidad de dirigir las "riendas" de la ejecución del delito.

El concepto de autor mediato fue creado por puras razones político-criminales consistentes en las lagunas que generaba un concepto de autor fuertemente influido, hasta ese entonces, por las necesidades causales del sistema de imputación reinante. Por ejemplo, bajo la vigencia de la teoría de la accesoriedad "extrema" no era admisible el castigo de los casos de participación (complicidad necesaria o no necesaria o instigación) en los casos de autores directos que actúan sin culpabilidad.24

En estos supuestos se produce un traslado del dominio del hecho del autor que ejecuta en forma directa al autor que está detrás justamente por ese defecto de la imputación objetiva o subjetiva del ejecutor. Así, "el autor mediato tiene el dominio del hecho porque consigue la instrumentalización de una persona, mediante la utilización de unos medios ante situaciones que inciden directa o indirectamente sobre aquélla, cuya actuación determina la comisión del delito. El autor mediato domina, pues, la cualidad lesiva del comportamiento del sujeto de adelante". 25

En el Código Penal de República Dominicana no existe una fórmula legal que se refiera expresamente a los casos de autoría mediata, es por ello que el concepto de autor mediato requiere una concepción "teleológica" de autor como sujeto de imputación en el derecho penal.

La consideración de el que "está detrás" como autor mediato se desprende de las diferentes formulaciones de 
los tipos de la parte especial.26 Se trata, en el ámbito del tipo de acciones ilícitas que aquí se analizan, de un instrumento indispensable. No cabe duda que en innumerables ocasiones quien conduce el aparato criminal a efectos de lesionar el bien jurídico protegido en materia de lavado de activos no ha realizado de mano propia el hecho que se le debe imputar. Se trata de la utilización de grandes estructuras en los que, en muchas ocasiones, el autor directo, el más cercano al hecho, sólo participa en términos físicos.

No hay ningún obstáculo en el Derecho Penal dominicano para imputar al autor mediato el hecho definido típicamente. Se trata de la propia interpretación de la ley.

Existen diversas posibilidades teóricas de autoría mediata:

- El autor inmediato puede no ser punible ya sea por engaño, violencia, o directa falta de idoneidad, por ejemplo, en los tipos penales de autor calificado (delitos especiales propios).

" $A$ " hace tomar una bebida alcohólica a "B" ocultándole que tiene disuelto un veneno de gran poder, " $X$ " obliga a " $Y$ " a autolesionarse, un funcionario público le encomienda a su Secretaria la realización de un acto que lesiona los intereses confiados a su cuidado, etc. La no solución de estos supuestos a través de la teoría de la autoría mediata generaría una nítida laguna de punibilidad.

- El autor mediato genera en estos casos el dominio del hecho a través de la utilización de un instrumento que tiene un error de tipo y que por ello, a pesar de ejecutar directamente el suceso, no tiene capacidad de dirigir las "riendas" de la ejecución del ilícito.

El ejemplo conocido del médico que utiliza una enfermera ignorante del contenido de la jeringa con la cual, por indicación del mismo médico, debe inyectar una sustancia tóxica al paciente. 0 el Gerente de una entidad financiera que le encomienda a un subordinado la realización de una compleja maniobra financiera, sobre fondos cuya legitimidad de origen el Gerente convence al empleado, y éste ejecuta sin saber que se trataba de un proceso tendiente al lavado de esas divisas.

La fundamentación del dominio de la ejecución del suceso del autor mediato parte de, justamente, esta relación inversamente proporcional entre el déficit verificado de información del instrumento y el plus de información del autor que se encuentra detrás. El grado evidenciado de este déficit informativo en el ejecutor "stricto sensu" será relevante frente a la eventual responsabilidad por negligencia en relación con el resultado disvalioso no querido pero, de todos modos, evitable con un actuar diligente. Que el error sobre los elementos de descripción de la conducta prohibida (tipicidad) sea evitable o inevitable no modifica en nada el dominio doloso del suceso en el autor mediato. En cambio, frente a un autor inmediato que conoce más de lo que cree el autor mediato comienza a ser discutible la responsabilidad de éste último en relación con el resultado. Todavía subsistiría la 
tentativa punible, frente a la cual habría que establecer el grado de idoneidad.

Jakobs se ha ocupado especialmente, en el marco de un ingreso teórico a través de la imputación objetiva, de estos casos "el hombre de atrás sólo responderá de un comportamiento de otro que actúa por error en caso de que concurra competencia. Pero, ¿cuándo existe tal competencia? Puesto que se trata del comportamiento de una persona que actúa por error, cabe pensar en dos fundamentaciones (que son acumulables y de hecho concurren con frecuencia conjuntamente en un mismo supuesto): en primer lugar, puede suceder que la relación del hombre de atrás hacia el comportamiento del otro tenga como consecuencia que sea cometido de aquel tener en cuenta el error de éste. En segundo lugar, puede que sea su relación con el error del otro lo que dé lugar a su obligación de considerar el comportamiento de éste". 27

- El autor que está detrás puede, en ocasiones, dominar la ejecución del acto ilícito mediante la instrumentalización de un sujeto que actúa, él mismo, en el marco -objetivo y subjetivo- de una norma permisiva. Ello se verifica en los supuestos en los que el autor mediato ha provocado intencionalmente la situación de legítima defensa del instrumento frente a una agresión -también dominada por el que "está detrás"- ilegítima de un tercero.

Para el autor directo no queda otra salida que comportarse de un modo lesionador, pero, de todos modos, lícito -para él. Más allá de lo aquí afirmado es preciso advertir que esta posibilidad de imputación por autoría mediata frente a instrumentos justificados ha constituido fuente de viva discusión normativa. Debate fielmente representado en las posturas de Hegler y Mezger. Según este último autor, la autoría mediata requería siempre una acción antijurídica del instrumento. Para Mezger si el propio autor inmediato actuaba conforme a derecho no podría ofrecer la ilicitud del comportamiento del que domina "de atrás". Se trata de casos, sin embargo, que son difíciles de imaginar en el ámbito del delito de lavado de dinero.

- Una forma tradicional de explicar los supuestos de autoría mediata pasa por ejemplificar a través del instrumento que obra en forma inculpable. Ello remite a tantos casos de autoría mediata bajo este modelo de imputación como circunstancias de no culpabilidad admita la respectiva categoría dogmática. En este sentido es posible imaginar casos de instrumentos que obran en error de prohibición inevitable o invencible, o sin capacidad genérica de culpabilidad -minoridad o alteración de las facultades mentales-, o -para quien así lo considere- en el contexto de un estado de necesidad disculpante -inexibilidad-.

- El otro de los supuestos que puede plantearse en delitos de alta complejidad, como el que está analizándose, es el caso de la autoría mediata que se realiza a través de la organización de poder28 -en este caso, se entiende que en la estructura privada por oposición a la estatal-. Aquí, el dominio del hecho lo tiene el autor de escritorio -mediato-, aunque el ejecutor directo también es perfectamente punible porque el cumplimiento de la orden no lo exime de responsabilidad. Mucho menos aún queda eximido quien da la orden, pues cuanto más lejano al 
hecho concreto se encuentre el autor, más se consolida la teoría del autor mediato a través de las estructuras.

En ese sentido, que el ejecutor sea punible no descarta, en absoluto, que el autor mediato también lo sea. A diferencia de la teoría de la autoría mediata que se explicó precedentemente, en ese caso, el autor comprende las circunstancias en las que actúa. Es decir, que no es un mero instrumento.

Por otro lado, la responsabilidad de quien emana la orden, radica, también, en la idea de que la estructura de poder permitirá que la orden se cumpla por la fungibilidad del ejecutor.

La ciencia del derecho penal le debe la construcción sistemática de esta categoría a Claus Roxín. Se trata básicamente del caso del miembro del aparato de poder militar que ejecuta una orden recibida de un superior en la estructura de mando. La responsabilidad del autor que desde el escritorio da la orden ilegítima no se puede fundar en el dominio a través de la falta de punibilidad del autor inmediato. Aquí el ejecutor es perfectamente punible. Es por ello que la responsabilidad del autor mediato debe buscársela por un argumento propio del funcionamiento de estas grandes estructuras: la fungibilidad del instrumento. Más allá del contacto físico con el ejecutor o de la posibilidad de la decisión final de ejecución en manos del autor inmediato, es claro que el dominio del hecho se basa en la propia estructura del órgano que asegura indefectiblemente que la orden se cumplirá. 29

En nuestro país el ingreso triunfal de esta categoría conceptual se produjo en el llamado "juicio a los comandantes" que detentaron el poder políitico de facto durante la dictadura militar.

Según Roxín, "el factor decisivo para fundamentar el dominio de la voluntad en tales casos (que se presenta como la tercera forma de autoría mediata, delimitada claramente con respecto al dominio por coacción y por error) reside, pues, en la fungibilidad del ejecutor. La estructura de esta forma de dominio y su relación con las otras dos formas básicas del dominio de la voluntad cabe incluso anticiparla, llevando a cabo una abstracción en tipos ideales a partir de la pluralidad de los sucesos reales. Si uno se para a reflexionar, por ejemplo, sobre cómo es posible guiar un suceso llevado a cabo por otro sin intervenir directamente, cabe pensar, a mi juicio, únicamente en tres formas: puede forzarse al agente; puede utilizársele como factor causal ciego con respecto a la circunstancia decisiva para la autoría, o el ejecutor tiene que ser, sino está coaccionado ni engañado, cambiable a voluntad". 30

Para Kai Ambos la explicación y fundamentación de la autoría mediata en estos casos requiere la utilización de la figura del dominio por organización. Solo que ello más que dar una respuesta, significa el planteo del problema: todavía queda por ver, como el mismo autor lo reconoce, cuáles son aquellas características de organización que posibilitan el funcionamiento racional de este sistema de imputación. ${ }^{31}$ 
En este punto es básico comprender que se trata de un modelo de imputación a la cuenta del autor que se desconecta por completo de cualquier exigencia causal como la cercanía física con el comportamiento. Es más, cuanto más lejos en la cadena de mandos se ubica el que da la orden del hecho mismo, más se consolida la imputación a título de autor mediato.

En el ámbito de los delitos de lavado de dinero es inevitable pensar que quien se encuentra, por ejemplo, en el marco de una compleja organización financiera, más lejos del hecho, tiene, a su vez, más poder de ejecución y dominio, por el propio manejo de la estructura criminal.

\subsection{La coautoría en el ámbito del delito de lavado de dinero.}

Otra de las formas posibles de participación en los delitos que reprime la Ley 72-02 es la coautoría.

El concepto de coautoría viene determinado en forma absoluta por el concepto de autor e importa de ese ámbito todas las ambigüedades y dudas.

En principio es posible decir que en los casos de coautoría se trata de supuestos en el marco de los cuales la ejecución del hecho es codominada por dos o más sujetos activos.

El Código Penal dominicano no ofrece una regla precisa para encuadrar los supuestos de coautoría, aunque, como ya se ha afirmado, "ésta no depende en su existencia dogmática de un reconocimiento legal explícito, pues está -como la autoría mediata- implícita en la noción de autor".32

Todos los requisitos exigibles para el autor tienen que darse en el coautor: codominio del hecho, elementos especiales de la autoría y los elementos subjetivos exigibles en el tipo penal que se trate.

Desde el punto de vista del codominio del hecho se trata de que cada uno de los coautores tiene las riendas de una parte de la totalidad de la ejecución del ilícito. En delitos cuya descripción descansa en varios verbos típicos es preciso que esta división de tareas se manifieste en relación con el mismo verbo, ya que si uno de los coautores ha participado en la realización de otro verbo será en forma autónomo autor directo de ese verbo y ese tipo penal. Hay un tipo penal por cada verbo, una dificultad propia de este tipo de legislación a la que ya se ha hecho referencia.

El codominio del hecho implica división del trabajo correspondiente a la ejecución del hecho típico en el marco de un plan común. Este plan común remite a un plano subjetivo: todos los participantes en grado de coautoría deben encontrarse vinculados por una resolución común de realizar el hecho. Es por ello que, en materia de 
lavado de dinero, cuando el hecho se ejecuta en el marco de una gran organización con varios niveles de jerarquía vertical es difícil que desde la cúpula organizativa y hacia abajo exista coautoría, ya que no en todos los niveles se tiene el mismo nivel de información. En el ámbito de ilícitos de tanta complejidad, como el lavado de divisas, ello es relevante porque sólo podrá imputarse coautoría a quienes se encuentran en una homogénea situación de conocimiento del plan común. Esta resolución común es la que justifica dogmáticamente que exista una recíproca imputación directa de todos los aportes al hecho.33 Ello encuentra una adecuada limitación en la exigencia de que cada coautor debe ser un autor idóneo, él mismo, frente al ilícito que se comete. En el ámbito de la coautoría no rige el principio de la accesoriedad que para la doctrina dominante condiciona la imputación bajo las distintas formas de participación.

Sin embargo, últimamente Jakobs ha cuestionado la necesidad de esta exigencia de una decisión común en algunos casos de coautoría. Según Jakobs se pueden presentar casos en los cuales un partícipe colabora en tal alto grado de intensidad con el hecho "principal" que "codetermine esencialmente la configuración de la ejecución en cuanto a lugar, tiempo y modalidades", incluso sin que lo sepa el autor "principal".34. El ejemplo con el cual se ilustra el supuesto teórico es bastante gráfico: "Alguien le da un somnífero a la víctima, a quien se va a matar a golpes mientras duerme, sin mediar acuerdo con el ejecutor, le abre además la puerta al autor, deja preparado un instrumento comisivo apropiado y además después de utilizarlo, y finalmente, antes de la ejecución del hecho, impide que terceros perturben la ejecución. La autoría única (autoría simultánea) de los partícipes decae por la falta de acciones de ejecución propia, la autoría mediata por la falta de subordinación del ejecutor, y por último la coautoría, según la doctrina dominante, por la falta de un plan común, de modo que sólo quedará la posibilidad de complicidad, decisión cuando menos dudosa. Por eso será más correcto, en lugar de una decisión común del hecho, en el sentido de un acuerdo siempre recíproco, conformarse en estos casos con una decisión de ajustarse, con la que el partícipe que no ejecuta directamente, pero coopera en la configuración, vincula su aportación con el hacer del ejecutor. Si el ejecutor no sabe nada de esta aportación, no se le puede atribuir nada de la gravedad delictiva de ésta, lo que se deriva de las reglas generales". 35

Más allá de esta objeción parece que es difícil considerar que el ejecutor que actúa con posterioridad, de un modo u otro, no sigue teniendo en forma absoluta y sin ninguna posibilidad de ser relativizado el dominio sobre las riendas del suceso.

El aporte objetivo al hecho de un coautor debe llegar a un nivel de trascendencia funcional que como mínimo permita suponer que el hecho no podría haberse cometido sin la participación del coautor que se trate.

La exigencia de una resolución común llevaría implícita la imposibilidad de que se pueda dar un supuesto de coautoría en el ámbito de un delito imprudente. En todo caso, se trataría siempre de supuestos de autorías 
paralelas, si ello fuera posible en el delito imprudente, cuestión muy discutible (el problema remite al criterio del "comportamiento alternativo conforme a derecho" que integra el juicio de imputación del resultado).

Enrique Bacigalupo36 entiende que la distinción entre la cooperación necesaria y la coautoría reside en primer lugar en un aspecto temporal: que ya exista o no comienzo de ejecución. Tal planteo merece alguna discusión. La división entre coautoría y cooperación necesaria desde ese punto de vista genera la dificultad adicional de casi aniquilar la posibilidad de que exista cooperación necesaria durante la ejecución del ilícito, lo cual deja entrever alguna laguna en donde se ubican los casos de cooperación necesaria durante el acto ilícito que, sin embargo, no llega hasta el punto de "tener las riendas" del suceso. Tal limitación no es correcta.

\section{Los problemas concursales}

Teniendo en cuenta lo novedoso de la estructura típica del lavado de dinero y su propia complejidad no sólo fáctica, sino también normativa, es posible que en los casos que tramitan por ante el sistema de administración de justicia penal los actos de lavado de dinero o lavado de divisas aparezcan relacionados con otras figuras normativas un poco más comunes. Es por ello que es preciso tener en claro de qué modo debe resolverse este tipo de conflictos de normas. Ello es materia de la teoría del concurso de delitos.

Por otra parte, considerando que el Código Penal dominicano no se ha ocupado en demasía de este tipo de problemas hermenéuticos, es necesario que el fino criterio interpretativo del juez resuelva gran parte de los problemas que aquí serán planteados. En última instancia, aunque la ley penal haga silencio, se trata de criterios generales de interpretación de la ley.

\subsection{Las reglas concursales y el lavado de capitales}

La teoría del concurso de delitos y del autor representan los dos complementos más importantes de la teoría de la imputación para terminar de configurar el conjunto de reglas que definen la materia de la prohibición y dan base al juicio de ilicitud en el ámbito del injusto.

En el caso de la teoría del concurso, pocos temas de la dogmática jurídico-penal han mantenido al día de hoy tan alto índice de confusión ya en las primeras reflexiones y en las manifestaciones prácticas de la teoría. Ello, probablemente, se debe a que los diferentes problemas han sido solucionados con métodos absolutamente disímiles y hasta contradictorios. Por un lado, algunas cuestiones han recibido un tratamiento puramente dogmático y con un índice indeseable de abstracción, mientras que otros temas han sido enfocados con un pragmatismo político criminal que sorprende -por ejemplo, el caso del delito continuado-. Este salto continuo 
entre el sistema y las consecuencias, en un mismo ámbito temático, posiblemente ha hecho perder el norte de los juristas hasta el punto de que hoy la teoría del concurso se encuentra en un punto de estancamiento conceptual.

A esta bifurcación de métodos científicos se suma, como lógica consecuencia, la convivencia, no siempre productiva, de principios generales del derecho, axiomas de permanencia indiscutida en la cultura jurídica occidental - por ejemplo, "les specialis derogat legi generali"- y problemas que no pueden dejar de enfocarse, en algún porcentaje relevante, frente al caso concreto, como la determinación judicial de la pena.

Así como la construcción del supuesto de hecho que debe ser sometido al proceso de subsunción presenta innumerable cantidad de dificultades, a menudo el jurista debe superar un conjunto de obstáculos a efectos de definir el tipo penal aplicable al caso de punibilidad que debe recibir una respuesta normativa.

Dentro de esos obstáculos se encuentra la cuestión de la relación existente entre diversas normas que eventualmente pueden reclamar ser convocadas a la solución del caso.

La teoría del concurso de delitos, independientemente de las posibles imprecisiones de su nomenclatura, se ocupa de ofrecer un conjunto de reglas al intérprete para poder clasificar la relación existente entre esas normas y ofrecer una respuesta unívoca al momento de subsumir el supuesto de hecho y determinar en forma precisa el fundamento de la contrariedad al derecho de la acción analizada.

La cuestión presenta distintas aristas según se definan algunas características del caso en concreto como ser la existencia de una o varias acciones y la relación entre las diferentes normas que concurran.

Tradicionalmente se ha dividido el análisis de la concurrencia de delitos según la ubicación respecto a lo que la doctrina ha llamado un "concurso aparente de leyes" o un "verdadero concurso". Básicamente con esta clasificación se trata de determinar si se trata sólo de una relación de tipos penales, en la cual, uno de los tipos, por diferentes razones que serán enseguida revisadas, desplaza al otro o si, por el contrario, se trata de que los tipos penales que concurren reclaman, todos ellos, ser convocados a la solución del caso.

\subsection{Concurso aparente de leyes}

En los casos de concurso aparente de leyes penales a primera vista pareciera que una misma conducta recibe de parte del ordenamiento jurídico más de una valoración, aunque en verdad lo correcto es interpretar que sólo una de las normas concurrentes es la que tiene absoluta legitimidad dogmática para "valorar" la conducta analizada. Es decir, salvo la norma que legítimamente debe definir normativamente el caso, las otras son 
desplazadas por imperio de un conjunto de principios de interpretación que ofrecen los argumentos para identificar el tipo penal en el que la acción se subsume en forma completa37.

En el caso del verdadero concurso para valorar en forma absoluta el supuesto de hecho hay que recurrir a todas las normas que en el caso concurren. En cambio, en el marco del concurso aparente de leyes, solo uno de los tipos penales es legítimamente aplicable.

Es por ello que muchas veces se ha opinado que cuando se analiza correctamente al concurso aparente de leyes se advierte con claridad que no se trata de un problema de concurso, sino de determinación de la ley38. Aunque en verdad, no es claro que ello sea un extremo que los distinga del verdadero concurso (ideal o real), ya que también en el concurso clásico se trata de un problema de interpretación de la ley o determinación de los preceptos aplicables a un caso.

"En las situaciones que aquí tratamos -especialidad, consunción, subsidiariedad y alternatividad- el concurso normativ039 sólo es aparente, pues una ley determinada de acuerdo con ciertas pautas desplaza la aplicación de las restantes". 40

Ahora bien, conviene detenernos, como él mismo lo hace, en la evaluación de cada uno de los supuestos.

Clásicamente los principios que han conformado a la teoría del concurso aparente de leyes son los siguientes:

\subsubsection{Especialidad}

Dentro del concurso aparente de leyes aparece con nitidez el principio de especialidad. No se trata de otra cosa que de una manifestación del axioma que estipula que la ley especial deroga a la ley general para la solución del caso en concreto (les specialis derogat les generalis). Esta relación de especialidad se comprueba cuando un tipo penal contenga todos los elementos constitutivos de otro con el cual entra en conflicto, pero presente una característica adicional. La relación podría graficarse como la que existe entre un conjunto de acciones definidas por sus características básicas y un subconjunto que agrupa, dentro de esos comportamientos, algunos que se identifican por la presencia de un elemento adicional. Es por ello que cada vez que se realiza la conducta del tipo penal que aparece a la vista del intérprete como especial, se realiza también -desde un punto de vista lógico-, el comportamiento definido por el tipo penal base.

Entre los dos tipos penales uno de ellos aparece como privilegiado o calificado.

Existen ejemplos que pueden demostrar esta relación de modo claro: el tipo penal del lavado de dinero 
desplaza por especialidad a la forma básica del encubrimiento. No tendría sentido que un mismo autor sea sancionado dos veces por el encubrimiento tradicional y, además, porque su encubrimiento ha posibilitado dar apariencia de legitimidad al origen de los fondos. En ocasiones, la determinación de la relación de especialidad presenta dificultades que no es sencillo superar. En algunos tipos penales no se obvia la decisión acerca de si se trata de una relación de especialidad o de dos tipos que deben ser tratados como autónomos. A menudo, asimismo, no se ve con claridad si la relación es tipo básico-tipo agravado o tipo básico-tipo atenuado.

Para superar este tipo de obstáculos hermenéuticos se debe tener presente la necesidad, en ocasiones, de dar importancia relativa a las palabras de la ley y acudir a los bienes jurídicos protegidos en cada tipo penal y, eventualmente, al grado de protección (cuando se trata de un mismo bien jurídico).

\subsubsection{Subsidiariedad}

Los casos de subsidiariedad significan supuestos en los cuales sólo es razonable aplicar uno de los tipos penales en juego, desplazando al tipo auxiliar que sólo reclama aplicación en caso que fracase la intervención del tipo penal "de subsunción primaria" -les primaria derogat legi subsidiariae-.

Este principio resuelve casos en los cuales un tipo penal sólo pretende tener vigencia para la solución de un caso, en supuestos en que la acción no implique la realización de un tipo penal de mayor gravedad. Es en este sentido que el precepto desplazado es subsidiario en relación al que regula la conducta de mayor trascendencia. Por ejemplo, si un sujeto activo ha participado de algún modo prestando una colaboración para la realización del delito de lavado de dinero y al mismo tiempo ha realizado otro delito de posible mayor 0 menor gravedad con el mismo acto, por ejemplo algún delito de falsedad del instrumento o de administración fraudulenta de los bienes en juego en perjuicio de un tercero.

Este tipo de subsidiariedad puede ser expresa o tácita. Es expresa cuando el propio legislador ha manifestado esta subsidiariedad en la configuración del tipo penal (por ejemplo: será sancionado con tal penal, siempre que la acción no signifique un delito más severamente castigado, etc). Es tácita cuando esta prevalencia de un tipo penal sobre el otro tiene que ser extraída del sentido mismo de las normas en juego (por ejemplo lo que sucede en un caso en el cual un sujeto ha sido partícipe y autor a la vez, o la relación existente entre el delito imprudente y el doloso, la imprudencia siempre es subsidiaria).

No ha estado fuera de duda la autonomía de este criterio, sobre todo, frente al concurso ideal.

La idea de que los límites entre el concurso ideal y el aparente son altamente difusos adquiere en el análisis de los casos de subsidiariedad elementos para apoyar la tesis. Tanto en el concurso ideal como en el aparente 
por subsidiariedad no se exige ninguna relación en abstracto entre los tipos penales en juego, sino sólo la que otorga la acción en el caso concreto, aquella que se verifica cuando la acción ha violado dos tipos penales que no tienen entre sí vinculación lógica alguna, o por lo menos no necesariamente.

Incluso en el único caso que se podría advertir alguna relación, como en los supuestos de subsidiariedad expresa -aquella dispuesta en la misma ley-, la mayor parte de las veces es una manifestación de legislación orientada hacia los efectos políticos criminales en donde no hay razones de preocupación sistemática, sino de proporcionalidad punitiva.

En este tipo de concurso aparente, asimismo, tampoco hay razones para que, ante el fracaso de la punición por el delito privilegiado, no renazca la aplicabilidad del precepto desplazado. Generalmente las normas de subsidiariedad expresa condicionan la aplicabilidad de la norma secundaria a que el hecho no sea más "severamente penado" por la norma primaria, por lo cual si la mayor pena en el caso concreto no se verifica, la norma secundaria retoma la vigencia para la solución del caso.

\subsubsection{Consunción}

Se sostiene, en general, que hay consunción cuando el contenido del ilícito de una clase de acciones incluye otra acción, "de manera que la condena desde una perspectiva jurídica expresa ya exhaustivamente el desvalor de todo el suceso"41, de modo que "normalmente la realización de un supuesto de hecho típico conlleva la de otro"42. En estos casos se supone que el legislador al regular la prohibición de la conducta más gravosa ha tomado en consideración que bajo esa forma típica se producen acciones cuyo desvalor acompaña normalmente al tipo privilegiado.

Una categoría como la de los "actos posteriores copenados" que a menudo ha sido analizada con algún grado de autonomía, en realidad comparte con la consunción la misma idea básica y, por ello, debe ser tratado como un subcaso.

Tampoco este grupo de casos han podido recibir un trato pacífico de la doctrina: no quedan claras, ante cada caso, las líneas divisorias con la subsiadiariedad y con la especialidad.

En el ámbito de los hechos y tipos penales que aquí se analizan ello puede darse con toda claridad, por ejemplo, en el caso de la tentativa y el delito consumado, también en el ámbito de los llamados "delitos progresivos", es decir, los supuestos en los cuales el accionar del agente va recorriendo diversas estructuras típicas de gravedad creciente (lesiones-homicidio; lesiones leves-gravísimas; tentativa-consumación, etc), 
Por ejemplo, el sujeto presta primero una colaboración de asesoramiento (inciso c del art. 3) y luego administra (inc. a del art. 3). No tiene sentido penar al sujeto dos veces.

\subsubsection{El verdadero concurso}

Junto al juego propio de estas reglas de interpretación, existen los casos llamados de "verdadero concurso". Se trata siempre de supuestos en los cuales el agente ha realizado la acción descrita en varios tipos penales y todos ellos reclaman un lugar en el análisis dogmático del caso.

Normalmente existen dos clases de concurso, según haya uno o varios hechos o, para usar la terminología de la doctrina mayoritaria, una o varias acciones.

Habrá concurso ideal de delitos si se advierte una sola acción y más de una violación a la ley penal y concurso real si existe más de una acción que producen, asimismo, más de una violación a la ley penal.

Cada clase de concurso tiene distintas consecuencias jurídicas.

Como se ve, el criterio medular para determinar los límites entre los dos concursos posibles de delitos es la unidad de acción.

La complejidad propia del delito de lavado de dinero hace que en innumerables ocasiones junto con los actos encuadrados en los arts. 3 y siguientes de la Ley 72-02, los sujetos activos hayan cometido además otro tipo de ilícitos que pueden ser puestos en relación de concurso ideal (si todo ha sido realizado en un mismo proceso ejecutivo) o real (si hay autonomía de acciones).

Por ejemplo, si una entidad financiera utiliza fondos de los ahorristas, que extrae ilícitamente de sus cuentas, a efectos de producir operaciones complejas de compra de bienes en el extranjero, que son adjudicados como si pertenecieran legítimamente a sociedades o empresas radicadas en otros países, los responsables de esa entidad, junto con el proceso posterior de legitimación de activos ha realizado, previamente, un delito de administración infiel de los fondos depositados, cuya tipificación debe concurrir en forma real (varias acciones) con el propio delito del art. 3 de la Ley 72-02.

A pesar de que puede parecer lo contrario en una primera aproximación al tema, no ha sido nada sencillo definir con alguna consistencia doctrinal los criterios bajo los cuales se debe estructurar el concepto de unidad de acción. 
Entran en pugna aquí, como en casi toda la teoría del delito, criterios naturalistas y criterios normativos. Por supuesto que hay casos en los cuales la cuestión no debería plantear ningún problema específico. Si un autor tiene dolo de producir una lesión a otra persona y para ello ejecuta un acto de disparar con un arma de fuego y logra el resultado, no habrá nada que discutir al respecto. Aquí hay una absoluta coincidencia entre la unidad natural del acto y su única valoración jurídica.

Sin embargo, es posible pensar en ilícitos cuya confirmación típica exige, sin lugar a dudas, una pluralidad de actos que, de todos modos, reciben un tratamiento unitario: delitos permanente (privación ilegítima de la libertad) o compuestos por varios actos (violación). Este tratamiento de varios actos como si fuera uno solo se funda en una determinada vinculación interna y unidad de sentido.

Un caso especial de construcción normativa de la unidad de acción es el delito continuado. Se trata de casos en los cuales, desde el punto de vista de su análisis fáctico, no hay duda que se trataría de un conjunto de ilícitos autónomos, producidos por cursos lesivos independientes (concurso real). Sin embargo, por razones de la más pura política criminal se pretende su tratamiento en forma unitaria. Cabe decir que si no fuera por esta decisión externa y de lege ferenda la solución debiera ser la del concurso real. Ello puede tener relevancia en el marco de las normas que aquí se analizan.

Para que se pueda predicar de un caso la hipótesis del delito continuado deben verificarse algunos requisitos:

- todas las acciones deben haber realizado el mismo tipo penal.

- el bien jurídico lesionado debe ser siempre y en todos los casos el mismo.

- debe haber una unidad de "voluntad" y un dolo de continuación.

- debe existir cierta continuidad temporal y cierta frecuencia entre los hechos.

- no deben afectarse bienes personalísimos (integridad física, vida).

\subsection{La relación con el delito base}

Uno de los principales problemas en este campo tiene que ver con la relación entre el delito base o aquel que provoca el beneficio económico o del cual se desprenden los fondos y la propia acción de la reconversión de ese dinero.

Como ya se explicara, el art. 3 de la Ley comienza del siguiente modo: "A los fines de la presente ley, incurre en lavado de activos la persona que, a sabiendas de que los bienes, fondos e instrumentos son el producto de una infracción grave.... La realidad muestra que en la mayoría de las ocasiones los delitos de tráfico de drogas, 
por ejemplo, y de "lavado de dinero" o bienes procedentes de los mismos aparecen entrelazados íntimamente, al generar enormes beneficios económicos que necesitan ser introducidos en el circuito económico, comercial y financiero hasta darles apariencia de licitud". 43

(a) La acción prohibida consiste en participar, de alguna de las maneras previstas en la Ley, en la inversión o tráfico de ganancias o del beneficio económico obtenido por una operación de otro, por ejemplo, en la transferencia de dinero de un país a otro para ser invertido en este último país.

(b) La acción antecedente debe ser ilícita y punible, en el sentido de constituir un delito. Ello supone:

- que es típica, tanto objetiva como subjetivamente, en el sentido de alguna de las demás conductas prohibidas en esa Ley (ello ya indicaría, posiblemente, que se trata de una figura específica, agravada, de favorecimiento real [encubrimiento]);

- que, además, esa acción es antijurídica, esto es, que no está amparada por una regla de permiso;

- que el autor de la acción antecedente es culpable, esto es, que no opere en el caso alguna causa de disculpa, que evita el reproche, como, por ej., un estado de necesidad disculpante o el error sobre la ilicitud de su acción, que el autor de la acción antecedente estimó lícita;

- y, por fin, que esa acción antecedente es punible, es decir, que no exista una causa de exclusión de la pena para su autor.

Por lo demás, conforme a la prohibición mencionada y tratándose, por ejemplo, de una hipotética acción antecedente delictual no sucedida en el territorio nacional, la acción antecedente no sólo debería reunir esas características según nuestro orden jurídico, sino también, y principalmente, en el territorio extranjero donde ella ha sido llevada a cabo, según el orden jurídico allí vigente.

La cuestión acerca de la dependencia del tipo penal examinado de una acción antecedente ilícita, culpable y punible genera más de un problema desde el punto de vista de la interpretación de la Ley y, otros más desde el punto de vista de la posibilidad del sistema penal de probar los extremos vinculados a esa conducta que precede al lavado y le da sentido jurídico penal, mucho más aún si tal dependencia se pone en contacto con el dolo (tipo subjetivo) del autor del encubrimiento, esto es, de quien interviene en el tráfico o inversión posterior de las ganancias sin haber participado en la acción antecedente.

Es indudable que determinada legislación, al ampliar de modo posiblemente desorbitado las exigencias probatorias sobre el "supuesto de hecho", generará una condena anticipada al fracaso de cualquier investigación judicial, pero también absolutamente problemática es, sin duda, la afirmación, por ejemplo, de que el dinero provenía de algún delito "base" sin especificación de las acciones antecedentes y sus circunstancias modales, temporales y espaciales. Pregunta: ¿Se condenaría a un imputado de encubrimiento 
(favorecimiento real) por haber comprado alguna cosa, si no existiera la posibilidad de fijar específicamente la acción antecedente, al menos, una denuncia, con visos de seriedad, sobre el hurto de la cosa comprada, acción sucedida en un determinado tiempo y lugar, y de una manera determinada, aunque no se conozca al autor?.

Estas múltiples cuestiones, generadas por la necesidad de partir de una acción antecedente, son potenciadas a un número difícil de imaginar si las ponemos en contacto con la exigencia, que demanda la prohibición, acerca de los conocimientos que debe poseer el autor del delito que examinamos para incurrir en la prohibición.

\subsection{La construcción del dolo a partir de las circunstancias del hecho: nuevamente el artículo 4 de la ley $72-02$}

El art. 4 de la Ley 72-02 estipula que "el conocimiento, la intención o la finalidad requeridos como elementos de cualesquiera de las infracciones previstas en esta sección, así como en los casos de incremento patrimonial derivado de actividad delictiva consignada en esta ley, podría inferirse de las circunstancias objetivas del caso".

El legislador ideólogo de la norma que se está analizando ha querido acotar los casos en los que al ser de tan difícil comprobación el elemento subjetivo, el tercer observador puede utilizar como herramienta de comprobación de la voluntad realizadora aquellas circunstancias objetivas de cada caso en particular.

Pareciera que esta introducción que aporta el legislador es poco clara en el sentido de que al no haberse definido qué se entiende por circunstancias objetivas, da la impresión que quedan incluidas todas las manifestaciones de la voluntad realizadora, sin ningún limite real a la exclusiva manifestación de la voluntad del sujeto.

Entonces se tiene por ejemplo, que en aquellos casos, en los que aparentemente por las "circunstancias objetivas" un agente haga suponer que posee (art.3, apartado a) bienes que sabía provenientes de una infracción grave, incurriría en lavado de activos.

Se entiende que el legislador, al advertir la imposibilidad de probar un delito antecedente, ha sugerido que por "circunstancias objetivas" que no han sido definidas, un sujeto podría incurrir en lavado de activos.

Es de difícil aceptación, básicamente, en virtud de los principios de culpabilidad y de derecho penal del acto.

Las circunstancias objetivas de cada caso deben estar definidas, y luego se deberá probar si el sujeto tenía la voluntad realizadora que exigen las conductas reprimidas en la presente ley. 


\section{La tentativa del lavado de activos. La estructura del delito tentado y su manifestación en el sistema represivo del lavado de activos}

El art. 6 de la Ley 72-02 sobre el lavado de activos provenientes del tráfico ilícito de drogas, sustancias controladas y otras infracciones graves, estipula que en todos los casos "Ia tentativa de las infracciones será castigada como la infracción misma".

Conforme ha quedado plasmado en la Ley, la sanción penal que deberá aplicarse a los casos en que el sujeto realice la conducta prohibida en grado de tentativa, será la misma que en los casos en que se haya consumado la infracción. Veamos un ejemplo. La sección III de la Ley está dedicada a las sanciones penales. En ese sentido, el art. 18 dispone que "la persona que incurra en la infracción de lavado de activos previstas en las letras a) y b) del art. 3, será condenada a una pena de reclusión no menor de cinco (5) años ni mayor de veinte (20)...", es decir, si un sujeto a sabiendas de que los bienes, fondos e instrumentos son el producto de una infracción grave: a) convierta, transfiera, transporte, adquiera, posea, tenga, utilice o administre dichos bienes será pasible de la sanción penal del art. 18 antes mencionado. La misma sanción penal será aplicada al sujeto que realice la misma infracción, pero en grado de tentativa (ver art. 6).

Es evidente que la técnica legislativa utilizada, por la cual se aplica la misma sanción penal a la tentativa que al delito consumado, no ha sido la más idónea.

Ha sido expresado por gran parte de la doctrina44 que desde que el designio criminal surge como un producto de la imaginación en el fuero íntimo del sujeto hasta que se opera el agotamiento de la ejecución del delito, tiene lugar un proceso, denominado "iter criminis" o "camino del crimen", es decir, el conjunto de etapas que se suceden cronológicamente en el desarrollo del delito.

Así, encontramos para el desarrollo del delito, la concepción, decisión, preparación, comienzo de ejecución, culminación de la acción típica, acontecer del resultado típico y agotamiento del hecho.

Solamente podrán se objeto de sanción penal dentro de los momentos del "iter criminis", Isa etapas preparatoria, de tentativa, la consumación y el agotamiento.

Todas aquellas etapas que suceden en el fuero íntimo del autor, en ningún caso podrán ser alcanzadas por la tipicidad, en virtud del principio "cogitationis poenam nemo patitur".

Se ha dicho que la regla general es que el "iter criminis" comienza a ser punible con la actividad ejecutiva, es decir, cuando existe un principio de ejecución, los actos preparatorios son atípicos. 
La tentativa queda integrada por aquellos actos que van desde el comienzo de la ejecución hasta el momento de la consumación, todos los cuales, a diferencia de los actos preparatorios, si están alcanzados por la tipificación punitiva.

Ahora bien, se ha definido a la tentativa como una conducta tipificada a la que le falta el resultado, es decir, no se ha completado la acción típica. En este sentido, el disvalor de la conducta tentada es inferior al disvalor de la acción consumada, mereciendo en estos casos una escala punitiva también menor.

Es en este punto, en el que el legislador ideólogo de la Ley en análisis, se ha equivocado. Querer equiparar las escalas penales de las conductas tentadas a las consumadas aparece como una falencia en virtud de los diferentes disvalores que cada una contiene.

Es evidente que el legislador ha utilizado la llamada "teoría subjetiva", que funda la punición de la tentativa en la voluntad contraria o enemiga del derecho del autor, es decir, se ha querido combatir la voluntad criminal.

Al tratarse de un fundamento vinculado a la voluntad criminal del sujeto, en la tentativa y en el delito consumado, las voluntades contrarias al orden jurídico se equiparan y consecuentemente, también se equiparan las penas.

La referida teoría subjetiva ha sido materia de grandes críticas, vinculadas con la posibilidad de que el legislador haya querido de esa manera punir el ánimo del autor y extender el ámbito de lo prohibido a los actos preparatorios.

Otra de las críticas que ha recibido la teoría es la equiparación de la pena de la tentativa con el delito consumado. Debe entenderse que el legislador ha dejado de lado la punición de la tentativa en los casos en que el bien jurídico en concreto no corra peligro (teoría objetiva), resultando la atipicidad de la tentativa inidónea.

Para Zaffaroni45 "la equiparación de la pena de la tentativa con la del delito consumado obedece a un desprecio por el aspecto objetivo del injusto que no es una consecuencia de la tesis del injusto personal y complejo, sino hijo dilecto del derecho penal de ánimo, que abandona lo objetivo para desvalorar una voluntad enemiga del derecho, contraria al deber, que nos lleva al terreno de la más pura arbitrariedad".

En consecuencia, la opción que ha utilizado el legislador -teoría subjetiva- a la hora de dar fundamento a la punición de la tentativa demuestra que será punible aquella conducta del sujeto que no afecte bienes jurídicos en concreto y, además, con un sentido general autoritario, pretendiendo extender la punición a los actos 
preparatorios.

Si nos referimos a la estructura típica de la tentativa, debemos decir que se trata de una tipificación bimembre, es decir, la tentativa presupone una tipicidad subjetiva y su correlato objetivo, principio de ejecución y ausencia de resultado (falta de consumación).

Entonces, tenemos que, la tipicidad subjetiva en la tentativa, al igual que en los delitos consumados, requiere de un elemento esencial, denominado dolo.

Se define al dolo como el conocimiento y la voluntad de realizar todos y cada uno de los elementos de la tipicidad objetiva. En los casos de tentativa deberá exigírsele al autor haber tomado una decisión. Entonces, habrá dolo, cuando el sujeto ya ha tomado la resolución, cuya ejecución deja condicionada a que se de cierta circunstancia.

Veamos un ejemplo. El art.3 de la Ley en análisis exige que la conducta sea realizada a sabiendas, es decir, exige al sujeto que realice los verbos típicos con conocimiento y voluntad de todos y cada uno de los elementos del tipo objetivo. Así, debe conocer que "los bienes, fondos e instrumentos son el producto de una infracción grave...".

De ese modo la estructura general de la tentativa se define como un delito incompleto, es decir, contiene una tipicidad subjetiva completa y una tipicidad objetiva incompleta (ausencia de resultado).

Ya se ha dicho que el dolo es el mismo en los delitos consumados como en los delitos tentados. En consecuencia, si la conducta descrita en el tipo penal exige, aparte del dolo, algún elemento distinto, éste debe también integrar el aspecto subjetivo de la estructura de la tentativa.

Debe agregarse, que el grado de dolo exigido en los delitos consumados es el mismo para la estructura tentada. Así se tiene que en los casos en que el tipo penal deba ser realizado con dolo directo, en la estructura de la tentativa también se deberá exigir al sujeto que actúe con dolo directo. El mismo ejemplo debe ser utilizado para los casos en los que el tipo penal requiera una conducta realizada con dolo eventual.

\section{1. Principio de ejecución: actos preparatorios y actos ejecutivos}

Mucho se ha escrito sobre los criterios de distinción entre los actos preparatorios y los actos ejecutivos.

Sin perjuicio de lo expuesto, lo cierto es que conforme ya ha quedado expresado no existe un "delito de 
tentativa", es decir, como un tipo penal autónomo sino que existe tentativa de un delito.

Es en ese contexto que debe establecerse que el comienzo de ejecución siempre está relacionado con cada uno de los tipos particulares, respecto de los cuales la estructura tentada aparece incompleta, pues falta el elemento resultado en la tipicidad objetiva.

Conforme lo expresa Eugenio Zaffaroni, para poder distinguir entre actos preparatorios y actos ejecutivos debe apelarse "a la tipicidad penal misma de la tentativa y tratar de delimitar desde el ángulo del bien jurídico y de su particular forma de afectación: los actos de tentativa sólo pueden ser aquellos que se muestran como amenazantes, como capaces de infundir temor y de perturbar, consiguientemente, la relación de disponibilidad con el ente que el derecho considera que el hombre necesita para su autorrealización".

Entonces tenemos que, para poder distinguir la inmediatez de la conducta respecto de la realización típica, debemos apelar a la forma particular que asume el tipo penal en el caso concreto, determinado también en cada caso concreto el plan del autor.

Este criterio ha sido definido por la doctrina como "criterio objetivo-individual", e intenta relacionar la conducta típica particular con un elemento individual, el plan concreto del autor, que es valorado por un tercero.

En conclusión, para ese criterio, la tentativa comienza con aquella actividad con que el autor, conforme al plan del delito, aplica en forma inmediata a la realización del tipo del delito.

Para dar un ejemplo, habrá tentativa de transferencia de fondos cuando el sujeto a sabiendas que los fondos son el producto de una infracción grave, concurra a una entidad bancaria, con el plan de realizar una transferencia a una cuenta en el exterior, cuyos fondos una vez acreditados serán entregados al sujeto y, luego de entregarle el formulario al empleado bancario, advierte que en realidad no envió el dinero a la cuenta en el exterior sino que realizó una donación a una organización no gubernamental.

\subsection{La tentativa en delitos calificados, habituales y en la autoría mediata}

Hay acuerdo en los autores en determinar que en los casos en que exista una conducta calificada, ésta pueda continuar a la conducta básica. En éstos casos, habrá tentativa cuando se de comienzo de ejecución a la conducta calificada.

En los casos contrarios, es decir, cuando la conducta calificada es anterior a la conducta básica, hay tentativa cuando exista principio de ejecución en la conducta calificada previa. 
En los casos de delitos que exigen habitualidad, y esta es definida como un elemento subjetivo del tipo, distinto del dolo, y que la repetición de conductas es una presunción de habitualidad, parte de la doctrina más destacada ha entendido que existe tentativa.

En ese sentido se ha entendido que "el delito habitual se configura como una conducta acompañada de la intención de su repetición habitual, de modo que, mientras ese elemento subjetivo acompañe a la tentativa, ésta será típica"46.

Finalmente, en los casos de autoría mediata habrá tentativa cuando se acciona sobre el sujeto interpuesto para que cometa el hecho. Esta situación no se configurará cuando se determina a otro que actúa en forma meramente inculpable, en este caso, el interpuesto siempre será autor y el que determina no pasa de ser instigador, cuestiones que en definitiva serán resueltas por las reglas de la participación.

\subsection{Tentativa inidónea, delito imaginario (o putativo) y ausencia de tipo}

Ya se ha dicho que en la tentativa (idónea o inidónea) la causalidad se desvía de lo previsto en el plan de autor, provocando que no pueda concluirse con la conducta o que no pueda ocasionar el resultado.

Asimismo, en los casos en los que el sujeto actúa con un error de tipo, es decir, un error que recae sobre algunos de los elementos del tipo objetivo, tampoco puede avanzarse con la conducta, provocando que si el error es inevitable excluya el elemento subjetivo y concluya el análisis sobre la posible comisión de una conducta típica, antijurídica y culpable.

En los casos de tentativa inútil (cuando el medio elegido es inidóneo para lograr la consumación) la doctrina se ha puesto de acuerdo en afirmar que ante la existencia de un objeto inidóneo no puede hablarse de tentativa, puesto que ella requiere un comienzo de ejecución de la tipicidad objetiva, que requiere necesariamente un objeto idóneo para su configuración.

Si se piensa en un ejemplo, podrá afirmarse que no existe tentativa, es decir, no hay principio de ejecución cuando conforme al art.7 el "empleado, funcionario, director u otro representante autorizado de los sujetos obligados, adultere un registro..." que no ha sido incluido en el numeral 4 del artículo 41 de dicha Ley, por ser en este caso, un objeto inidóneo. 


\section{El desistimiento voluntario en el marco del delito tentado}

Puede ocurrir que el sujeto desista en forma voluntaria de la comisión del delito.

La doctrina ha discutido el lugar que ocupa en la pirámide de la teoría del delito. Así, se ha sostenido que el desistimiento es igual a atipicidad, argumento que no es correcto en virtud de que cuando el sujeto ha iniciado los actos ejecutivos, éstos son de carácter objetivos y subjetivos, en consecuencia no podría hablarse de atipicidad cuando la conducta ya se ha calificado de típica, aunque sí podremos coincidir en que la tipicidad se encuentra incompleta.

Otro sector de la doctrina ha encontrado al desistimiento como causal de inculpabilidad, pero la realidad es que al sujeto, sin perjuicio de que tomó la decisión de no continuar con la ejecución de la conducta prohibida, ese motivo posterior no podría dejar de lado que se le reproche por haber actuado en forma típica, antijurídica y culpable.

Finalmente, se ha sostenido que el desistimiento integra una causa personal que cancela la punibilidad del delito, 47 pero que no afecta ninguno de sus caracteres, que permanecen completamente inalterados.

En ese sentido, los partícipes no se benefician con el desistimiento del autor, salvo que ellos mismos desistan. Sin perjuicio de ello, la circunstancia de que el desistimiento del autor no beneficie al partícipe no excluye la posibilidad de un desistimiento del partícipe que tampoco beneficie al autor.

Creemos que ante un caso de desistimiento, es decir, cuando el propio autor es aquel que deja de lado el avance de las etapas previas que lo llevan a la consumación, el sistema represor renuncia a la aplicación de un castigo en virtud de que ha desaparecido el peligro que corría el bien jurídico protegido.

La formulación de que el sistema represor renuncia a la aplicación de un castigo tiene relación con la idea de que siempre es mejor que el autor desista antes de que se consuma la conducta prohibida.

Para que se den los presupuestos de un desistimiento, siempre debemos estar frente a una tentativa (presupuesto objetivo), es decir, frente a un principio de ejecución cuya tipicidad objetiva se encuentra incompleta por faltar el resultado y ante la presencia del elemento subjetivo, dolo, el conocimiento y la voluntad por parte del sujeto de que realizar todos y cada uno de los elementos del tipo objetivo.

Puede ocurrir que desaparezca la tentativa cuando el sujeto deja de actuar con dolo, es decir, cuando advierte que está en presencia de una tentativa fallida. En estos casos no podrá el autor desistir de una conducta que 
cree que es fallida, aunque en términos objetivos sea idónea.

Veamos un ejemplo. Cuando el sujeto sabiendo que los fondos que posee son el producto de una infracción grave, y comienza la ejecución de asistencia a un tercero ignorando que la asistencia que comenzó a otorgar no es idónea para lograr el lavado de activos y se arrepiente, estamos en presencia de un desistimiento voluntario en virtud de que el sujeto ignora que su tentativa es fallida, y objetivamente lo está.

\section{La tentativa en los delitos de estructura omisiva}

Conforme el art. 7, aparatado "c" de la Ley que se analiza, incurre en infracción penal "el funcionario público titular del órgano competente para la supervisión y fiscalización del cumplimiento por los sujetos obligados de las obligaciones puestas a su cargo en esta ley...no inicie el procedimiento administrativo sancionador en el plazo establecido...", es decir, en este caso de omisión puede afirmarse que existiría tentativa desde que el sujeto especial, con dolo de omitir la conducta ordenada, realiza una acción diferente, pues ya ha puesto en peligro el bien jurídico protegido, aumentando el peligro y disminuyendo la posibilidad de que se realice la conducta esperada.

En los casos de omisiones impropias el deber de actuar que emerge de la posición de garante, recién surge cuando aparece el peligro para el bien jurídico que se tutela. En consecuencia, con el primer hacer distinto del debido ya hay una tentativa, porque el sujeto debe actuar en razón de que hay peligro.

\section{Responsabilidad por omisión en posición de garante}

En principio no cabe ninguna duda que existe, en el marco de la Ley de lavado de dinero, la forma omisiva como modelo de imputación. Sin ir más lejos conviene recordar, por ejemplo, la omisión de inicio del procedimiento administrativo sancionador por parte del funcionario público encargado que se encuentra regulada en el art. 7 de la Ley mencionada. 48

Pero, más allá de las formas omisivas expresas, fácilmente reconocibles, conviene tener presente que en cada tipo penal de comisión se esconde una posibilidad imputativa omisiva, algo que, si bien ha generado alguna controversia en relación con el mandato de les stricta, ha sido aceptado mayoritariamente por la doctrina dominante.

Se trata de los casos de omisión impropia, en el marco de los cuales se imputa o atribuye al omitente no haber evitado un resultado, en el caso que se den las demás exigencias típicas de las estructuras omisivas (situación 
generadora del deber de actuar, capacidad de auxilio, no cumplimiento del deber), a las cuales se suma la posición de garante del omitente (ya como garante al cuidado de una fuente de peligro o como garante al cuidado de un bien jurídico sometido a riesgos).

Eso es importante, ya que en gran cantidad de ocasiones, sobre todo en hechos ilícitos realizados en el marco de estructuras de poder criminal o financiero organizado, el sujeto de máxima responsabilidad no realiza el hecho de modo activo sino que no interrumpe, cuando podría hacerlo, un proceso lesivo que en última instancia depende de él.

La forma omisiva impropia remite a la misma pena que la forma comisiva. 
1 Diego J. Gómez Iniestra, El delito de blanqueo de capitales en Derecho Español, Cedecs, Barcelona, 1996, pág. 21.

2 Isidoro Blanco Cordero, El delito de blanqueo de capitales, Aranzadi, Pamplona, España, pág. 31.

3 Manifestada en la llamada "lista negra" del Grupo de Acción Financiera Internacional (GAFI).

4 Un inconveniente que se debe adelantar aquí se relaciona con la utilización indiscriminada de verbos típicos con un afán de que todo lo que pase cerca de lo que entiende por "lavado de dinero" quede abarcado por la prohibición. Ello, como se verá, no sólo complica indebidamente la tarea de interpretación de la ley penal que corresponde a los jueces, sino que multiplica hasta el infinito los posibles tipos penales: no hay ninguna duda que cada verbo representa un tipo penal sustentado muchas veces en conductas de muy distinta gravedad.

Esta verdadera inflación gramatical ha posibilitado incluso que se transforme al delito de "blanqueo de capitales" en una de sus modalidades en un delito de tenencia, haciéndose cargo de todos los problemas que implica la incorporación del verbo tener en una figura penal. Entre otros el hecho tan simple como chocante de que "todos los significados de la palabra "tener" no conciernen ni remotamente a una conducta en el sentido de la ejecución u omisión de un movimiento corporal voluntario". El hecho de que este error ya ha sido cometido por varios legisladores de América Latina y del Caribe, e incluso de otros países en el derecho penal comparado, por ejemplo al momento de regular la "tenencia de arma de guerra", no puede ocultar que sólo es posible pensar en un "tener" como "actuar" en los casos siguientes: a) adquisición de la tenencia mediante una acción, por ejemplo, compra, recepción, sustracción de una cosa; b) impedir mediante una acción la pérdida de la tenencia que está por producirse, por ejemplo, ocultando armas ante un registro inminente 0 deglutiendo un recipiente con droga o c) emplear o utilizar la cosa, por ejemplo, viajar con el auto, disparar el arma, consumir droga, 0 comprar una empresa con el dinero que requiere ser blanqueado.

Sin embargo, "los casos de las actividades expuestas no pueden ser caracterizados según las reglas y el significado corriente del idioma castellano como "tener".

La incorporación de este verbo en la legislación analizada sólo responde a facilitar, en verdad hasta lo inadmisible, la actividad jurisdiccional de adquisición de prueba del ilícito.

No se olvide que la última vez que el mundo occidental utilizó estrategias similares en forma general ello coincidió con el positivismo criminológico italiano para el cual el "ser" de una determinada manera (por ejemplo "peligroso") ya constituía lo ilícito. Una de las conquistas más importantes del derecho penal liberal ha consistido justamente que en el pasaporte de un ciudadano para el sector de lo punible deba constar haber realizado una acción prohibida o haber omitido un cumplimiento de una acción debida.

5 Zaffaroni, Eugenio R., Manual de Derecho Penal, pág. 396, Editorial Ediar, 1987.

6 Diccionario de la Real Academia Española, vigésima segunda edición, tomo I, editorial Planeta, Buenos Aires, 2001, página 648.

7 Ob. cit, tomo II, pág. 2210.

8 Ob. cit, tomo II, pág. 2212.

9 Ob. cit, tomo I, pág. 49.

10 Ob. cit. tomo II, pág 1808.

11 Ob. cit, tomo II, pág. 2154

12 Ob. cit, tomo II, pág. 2260.

13 Ob. cit, tomo II, pág. 2609

14 Maier indica que este es el primer antecedente que introdujo claramente el principio de inocencia. También anuncia límites al principio de incoercibilidad del imputado durante el proceso. Ver Derecho Procesal Penal, Editores del Puerto, Tomo I, 1996, pág 511.

15 Fontán Balestra, Carlos, Tratado de derecho penal, parte especial. Tomo VII, página 321, Abeledo Perrot.

16 Marcelo Sancinetti, "Sobre la inconstitucionalidad del llamado del llamado delito de enriquecimiento ilícito de funcionario público (el adios al estado de derecho)", publicado en Cuadernos de Doctrina y Jurisprudencia Penal, n 8, - C, pág 943, Editorial AdHoc, Buenos Aires, Argentina.

17 Gabriela B. Basualdo, "El delito de enriquecimiento ilícito", en Nueva Doctrina Penal, Editores del puerto, Buenos Aires, 2003, página 14.

18 Maurach, Derecho Penal. Parte General, Ed. Astrea, pág. 320.

19 Maurach, ob.cit., pág. 317.

20 Roxin, Claus, Autoría, pág. 317 y ss. 
21 Jakobs, Günther, pág. 791.

22 Patricia S. Ziffer, Lineamientos de la determinación de la pena, Editorial Ad - Hoc, año 1996, página 132.

23 Maximiliano Rusconi, ob. cit., pág. 159.

24 "Supóngase en caso del gerente de una empresa importadora que -para lavar y repatriar dinero a otro estado- actuando en connivencia con una fábrica extranjera integrada como aquélla a la organización dedicada al blanqueo, ordena a un subordinado que viaje y concrete la compra de determinados artículos producidos por esa fábrica a cualquier precio (alegando tener un seguro comprador), el que es en definitiva sobrevaluado por el vendedor (de manera que se justifican en el país de origen de esos artículos las sumas que se derivan del sobreprecio girado por la firma compradora); en tal situación cabe atribuir el hecho al gerente de la empresa importadora como autor mediato que realiza el tipo a través de otro sobre quien siempre mantuvo el control de la actividad, ya que el empleado "instrumento" sólo actúo obedeciendo la orden del superior y con absoluto desconocimiento de la maniobra que éste llevaba a cabo por su intermedio, es decir, sin el dolo que requiere la figura de lavado".Ver, Jorge Barral, Legitimación de bienes provenientes de la comisión de delitos, Ad-Hoc, Buenos Aires, julio 2003, pág. 212.

25 Welzel, Hans, Derecho penal alemán, pág, 122.

26 Hernández Placencia, Autoría Mediata, pág. 80.

27 Mir Puig. Derecho Penal. Parte General, Mir ediciones, pág. 385 y sgtes.

28 Jakobs, La imputación objetiva, Universidad Externado de Colombia, pág. 16.

29 Ver, Juana Del Carpio Delgado, El delito de blanqueo de bienes en el nuevo Código Penal, Tirant lo blanch, Valencia 1997 , pág 273 y ss.

30 Derecho Penal.Parte General, Edsrsa, traducción de Gladis Romero, pág. 242.

31 Roxín, Autoría, pág. 270.

32 Kai Ambos, pág. 32.

33 Bacigalupo, Enrique, Derecho Penal. Parte General, pág. 365 y ss.

34 Jescheck, Tratado..., pág. 616.

35 Jakobs, ob. cit., pág. 747.

36 Op.cit.

37 Bacigalupo, Derecho penal. Parte General, pág. 367.

38 Una posición original ha tenido, entre nosotros, Carlos Nino. En ella el autor argentino objeta la creencia generalizada de que en los casos aquí analizados se trate de un concurso de leyes que sólo existe "en apariencia".

"En las situaciones que aquí tratamos -especialidad, consunción, subsidiariedad y alternatividad- el concurso normativo sólo es aparente, pues una ley determinada de acuerdo con ciertas pautas desplaza la aplicación de las restantes.

¿Se justifica esta distinción tradicional? Creo que no. En efecto, la teoría explicada resulta artificiosa cuando presenta la cuestión como si en una primera lectura del código varias leyes parecieran concurrir en la calificación de una conducta, desvaneciéndose esa concurrencia en ulteriores lecturas mas atentas.

Lo cierto es que los casos desarrollados por la dogmática como de concurso aparente de leyes son, en su mayoría, casos de verdadera concurrencia. Justamente porque en esas situaciones hay varias leyes concurrentes en la calificación de un comportamiento es que la dogmática formula criterios para resolver tal concurrencia...

Por otra parte, la consecuencia mas importante que caracteriza, según el pensamiento dogmático, al verdadero concurso de leyes no es exclusiva del concurso formal, sino que se da también en algunos casos del llamado concurso aparente. Nos referimos a la posibilidad de aplicar la pena de la ley desplazada toda vez que el agente sea impune, por alguna causa de justificación, por ejemplo, de acuerdo con la ley de aplicación privilegiada. Según la dogmática esto sólo se da en el concurso ideal y no en el aparente. Pero rápidamente se incurre en contradicción cuando se sostiene que la característica distintiva de la subsidiariedad respecto a otra clase de concurso aparente es la aplicabilidad de la ley subsidiaria en caso de impunidad respecto a la ley privilegiada."

Nino, Carlos, El concurso en el derecho penal, Ed. Astrea, Buenos Aires, 1972, pág. 47 y ss.

39 Muñoz Conde, F, Teoría General del Delito, Tirant lo blanch, Valencia, 1991, pág. 200.

40 En este sentido es muy clara la definición de Günther Jakobs, Derecho Penal. Parte General. "Fundamentos y teoría de la imputación", traducción de Joaquín Cuello Contreras y José Luís Serrano Gonzalez de Murillo de la segunda edición alemana -Berlín, 1991-, Marcial Pons, Madrid, 1995, págs. 1048 y ss: "En el concurso de leyes, el comportamiento del autor se ve abarcado por diversas leyes en el sentido de formulaciones de delito, mientras que sólo se da una única ley en el sentido de determinación de delito: un delito idéntico se formula varias veces, desde luego quizá en distintos grados 
de concreción y por tanto de determinación de las consecuencias jurídicas. Por formulación de delito no ha de entenderse sólo el texto de la ley, sino el resultado de su concreción interpretativa en la subsunción, incluyendo la mención de los factores de determinación de la pena. Así pues, formulación de delito es la proposición jurídica concretada hasta la aplicabilidad al caso concreto".

41 La postura totalmente contraria ve en el concurso de leyes una situación que no tiene ninguna relación con el verdadero concurso sino con un problema de determinación de la ley.

Ver, Francisco Muñoz Conde y Mercedez García Arán, Derecho Penal. Parte General, tirant lo blanch, Valencia, 1993, pág. 414.

42Jescheck, op.cit., pág.674.

43Mir Puig, op.cit., pág.740.

44Diego Gómez Iniestra, pág. 17.

45 Zaffaroni, Eugenio Raúl. Tratado de Derecho Penal, Parte General, tomo IV. Editorial Ediar, Buenos Aires, septiembre de 1996, página 411 y ss.

46 Ob, cit, página 424.

47 Ob, cit, página 458.

48 Ob, cit, página 482.

49 Art. 7, inc. c) "El servidor público titular del órgano competente para la supervisión y fiscalización del cumplimiento por los sujetos obligados de las obligaciones puestas a su cargo en esta ley que, por omisión o a sabiendas de la falta grave incurrida por un sujeto obligado, su funcionario o empleado no inicie el procedimiento administrativo sancionador en el plazo establecido en el reglamento de esta ley". 



\section{5 \\ ASPECTOS PROCESALES EN EL ENJUICIAMIENTO PENAL DEL LAVADO DE ACTIVOS}

Norma Bautista, Heiromy Castro Milanés, Alejandro Moscoso Segarra y Olivo Rodríguez. Huertas

\section{Responsabilidades procesales del Fiscal y del Juez en el sistema acusatorio. La instrucción.}

Sin dudas, la instrucción se ha transformado en la etapa en la cual se definen los ejes probatorios y la misma producción de la prueba.

El modelo de instrucción define, asimismo, el modelo de control de la policía y demás organismos de investigación.

Pero, además, en esta etapa reside el máximo riesgo de lesión de las garantías individuales (actividades coercitivas, personales y reales).

Por otro lado, por la instrucción pasan la gran mayoría de los casos y, por lo tanto, en ella se definen las líneas político-criminales que regirán las salidas intermedias en el marco del proceso (oportunidad, probación, etc.) y reside un caudal decisorio de tremenda importancia, como falta de mérito, sobreseimiento, actividades coercitivas, etc. Es aquella etapa frente a la cual procesalistas como D’Albora, han podido decir que presentan las características de ser preponderantemente escrita, limitadamente secreta, escasamente contradictoria, etc.

Existen dos formas de resolver procesalmente y técnico-legislativamente el sistema de la instrucción: el modelo inquisitivo y el modelo acusatorio.

En casos de delitos complejos como el lavado de dinero es inviable el logro de un modelo de investigación eficiente sin contar con un sistema de investigación a cargo del Ministerio Público. 
Si el modelo inquisitivo que expone la figura del juez instructor se muestra en general ineficiente, ello se multiplica a la hora de investigar delitos más complejos.

El sistema acusatorio refleja un modelo más ágil, con mejores chances de acercarse a la producción del caso y con la ventaja adicional de que no contamina la imparcialidad del juzgador y con ello no lesiona la garantía del derecho de defensa.

Hoy ya es un lugar común la necesidad de aumentar los niveles de eficiencia de la administración de justicia penal, teniendo en cuenta que en muchas ocasiones la comunidad deposita en su propio rol la garantía de la vigencia social de los valores ético-sociales.

Una comunidad sin una justicia penal eficiente siente una fuerte debilidad en la real manifestación en el tejido comunitario de los valores éticos fundamentales.

Nuestra justicia penal, lamentablemente, ha estado siempre muy influida por los modelos inquisitivos vigentes en Europa Central hasta la supervivencia del Antiguo Régimen.

La herencia española, en cuanto a la importación de modelos judiciales, ha sido especialmente dañina a la hora de estructurar un modelo judicial. La inquisición ha significado: debilitamiento del rol de la víctima, procesos secretos, violación de las garantías individuales, utilización excesiva de los mecanismos de coerción, instalación de modelos absolutamente burocráticos, aniquilación del paradigma republicano del no autocontrol, y vigencia irracional del principio -absolutamente mítico- de legalidad procesal: Ia instalación de un sistema de ejercicio de la acción pública indelegable, permanente, nunca condicionado por ningún interés procesal y, la instalación absolutamente dañina de la figura del juez a cargo de la instrucción, un modelo de investigación jurisdiccional poco eficiente y que ha relegado al Ministerio Público Fiscal a un papel debilitado en relación a lo que sucede en sistemas judiciales más avanzados.

Ese tipo de decisiones pueden significar, de acuerdo a como se desarrolle el propio camino de su puesta en funcionamiento, o una nueva experiencia de más de lo mismo o el comienzo de una transformación de envergadura.

Ahora bien, una reformulación del modelo de instrucción depende en mayor medida del Ministerio Publico más que de la función judicial. La manifestación de una eficiente política criminal está supeditada a él, porque de él depende la defensa de los intereses generales de la sociedad. Ello por varias razones:

- La inserción correcta del organismo posibilita la defensa de un conjunto de garantías orgánicas (vigencia 
del principio de control externo).

- Como motor de la investigación es el mejor puesto de observación del flujo de información y de reformulación administrativa.

- De su mayor protagonismo depende la posibilidad de introducir criterios de política criminal. Por ejemplo, en las denominadas reglas de Mallorca se establece la necesidad de hacer coherente la políica de persecución criminal en supuestos de Investigación Penal Preparatoria a cargo del Ministerio Público (regla A3). Asimismo, hoy es un lugar común que el principio de oportunidad requiere de un sistema acusatorio.

Hay una trilogía que permite comprender y evaluar político-criminalmente a los sistemas procesales: a) el Modelo de instrucción: en el sentido de la distribución del poder de persecución penal, b) el Rol procesal del Ministerio Público y c) el Principio acusatorio.

El Ministerio Público tiene, sin embargo, otra función de máxima trascendencia, quizá la más importante desde una visión constitucional o de organización política del Estado: el resguardo de la forma republicana del ejercicio del poder.

No cabe duda, hoy día, que el sistema penal representa una de las formas más fuertes y violentas del ejercicio del poder estatal. Es por ello que tal ejercicio del poder debe estar en consonancia con el programa ideológico que el sistema constitucional organiza para enmarcar ese ejercicio del poder.

El sistema de organización del poder de una Constitución Política no tiene sólo efectos horizontales, es decir, en el sistema de relaciones programadas para la comunicación institucional entre los tres poderes del Estado. Ello manifestaría una comprensión muy superficial del modelo republicano y directamente contraria a su espíritu.

El sistema de división del ejercicio del poder con su modelo de frenos y contrapesos y la vigencia del "paradigma del no autocontrol", no son indicaciones constitucionales que sólo tienen vigencia como orientación hermenéutica de la Carta Magna sino que constituyen todo un programa ideológico del ejercicio del poder que debe ser llevado con especial cuidado y fidelidad a la organización de cualquier ejercicio de ese poder y sobre todo el penal.

La concepción de los modelos republicanos nació y siempre estuvo vinculada a la necesidad del reconocimiento de la garantía de la libertad individual, por lo cual es fácilmente observable la importancia de que el proceso penal esté en consonancia con el sistema políitico del Estado. De otro modo, es seguro que habremos relegado al texto constitucional a una función de "mero indicador de lo preferible", y negado su protagonismo allí donde con más firmeza debe influir. 
En ese sentido, es evidente que el sistema de "control externo " en el ejercicio del poder que la Constitución desarrolla tiene, afortunadamente, "efectos verticales" que deben ser trasladados al sistema organizativo del poder penal del Estado, en particular al modo como se diseña el sistema de enjuiciamiento: quien ejerce un poder en el sistema procesal penal debe tener un control externo de sus actos y no ser librado a la honestidad eventual de su "autocontrol". Ello debe ser definido como una garantía, para decirlo con las palabras de Ferrajoli, "orgánica".

Pues bien, el Ministerio Público es el organismo que más posibilidades tiene de provocar un diseño procesal que respete esa garantía.

Su ingreso como sujeto procesal en la escena del proceso posibilita la puesta en práctica de un sistema por el cual nadie deba ser "ni buen ni mal guardián de sus propios actos". Su presencia garantiza un modelo diseñado sobre la base de que quien ejerce el poder de investigar no tiene, al mismo tiempo, el poder de controlar.

Con ello se puede buscar, sin contradicción visible, la eficacia de la investigación y la eficacia del control.

En primer lugar, debemos aclarar que se parte de la crítica al modelo inquisitivo de ejercer el poder penal, como un modelo que no es sólo procesal sino fundamentalmente, una forma global de ejercer el poder penal del Estado. La cuestión central frente a la cual nos encontramos es un Ministerio Público reproductor del sistema inquisitivo o un Ministerio Público que comience a caminar hacia un sistema acusatorio. Esta decisión, en relación con los chances de lograr un sistema de investigación eficiente, es tremendamente trascendente.

Paradójicamente, en el proceso inquisitivo se ha invertido lo que debía ser la relación básica. Es el juez quien investiga (o hace que investiguen) y el fiscal "dictamina", es decir, opina sobre el valor de esa investigación. El Ministerio Público es un control de la administración de justicia. Por ejemplo, se le ha asignado la función de "ser custodio de la legalidad" (¿?); esta atribución de la tarea de "garante" de la legalidad, una de las opciones posible en la construcción del Ministerio Público, también ha contribuido a oscurecer su misión y, paralelamente, a oscurecer la misión de los jueces. "El Ministerio Público -señala Roxín- no fue concebido para cumplir una función unilateral de persecución, como ocurre con el acusador del proceso penal angloamericano, sino para ser "custodio de la ley". Ello significa: su tarea consiste en velar, a favor del imputado, porque se obtenga todo el material de descargo y porque ninguno de sus derechos procesales sea menoscabado".

El Ministerio Público no ha hecho ni una cosa ni la otra; ni ha sido garante de la legalidad ni ha sido un investigador. Esto no ocurrió por la negligencia de las sucesivas generaciones de fiscales. Esta falta de funcionamiento se debe a que, en la práctica, no se ha abandonado la cultura básica del sistema inquisitivo, que es tan inquisitiva como lo era en la España de Felipe II y dentro de ella el Ministerio Público no es un 
adolescente como sostiene Maier sino que es un extraño, un convidado de piedra, el invitado a una fiesta pero que nadie sabe para que está o que se espera de él.

El Ministerio Público, obviamente, se organizó sobre la base de esta oscuridad institucional y adquirió un tipo de organización refleja. Su identificación con el modelo de organización judicial fue completa. La institución extraña al sistema inquisitivo, la que según Roxín cobro vida como "medio de liberación ciudadana" frente a las arbitrariedades monopólicas del inquisidor, adoptó en nuestro continente los principios, modalidades y vicios de la cultura inquisitiva. Hoy todavía no sabemos, en qué medida, si el Ministerio Público es también una reserva de cultura inquisitiva. Frente a este panorama es necesario mirar al Ministerio Público como el órgano que puede comenzar a terminar con esa cultura.

\section{La libertad durante el proceso de investigación del lavado de activos}

Enfocaremos este aspecto desde la perspectiva de la figura jurídica de la prisión preventiva, y que constituye una de las medidas de coerción, también denominadas medidas cautelares personales.

La libertad del imputado durante el proceso de investigación del delito de lavado, que corresponde a lo que se denomina en el nuevo Código Procesal Penal como el "Procedimiento Preparatorio", y en el Código de Procedimiento Criminal jurisdicción de instrucción, está regida por dos principios constitucionales: el de la libertad y el de igualdad ante la ley, que por su categoría son de aplicación general a todos los tipos de ilícito y que conforman el debido proceso como se asume en la Resolución No. 1920, del 3 de noviembre del 2003, de la Suprema Corte de Justicia.

El estatuto de libertad establece que toda persona tienen derecho a la libertad y a la seguridad personales, que las medidas de coerción restrictiva de la libertad personal o de otros derechos tienen carácter excepcional y su aplicación debe ser proporcional al peligro que trata de resguardar (artículo 15 del Código Procesal Civil). En similar sentido se expresa la Declaración Universal de los Derechos Humanos, en sus artículos 3 y 9; el Pacto Internacional de Derechos Civiles y Políticos, del 16 de diciembre de 1966, aprobado por el Congreso Nacional el 27 de octubre de 1977, en sus artículos 9.3.4; Ia Convención Interamericana de Derechos Humanos, y el Pacto de San José del 22 de noviembre de 1969, aprobado por el Congreso Nacional el 27 de octubre de 1977, en sus artículos 7.1 .3 y .6; todas vinculantes para los jueces dominicanos.

El principio de igualdad de todos ante la ley, consagrado en el art. 8, numeral 5 de la Constitución política dominicana, estableced que "... la ley es igual para todos, no puede ordenar más que lo que es justo y útil para la comunidad ni puede prohibir más que lo que le perjudica". Y complementado este principio fundamental, el 
Art. 100 de dicha Constitución dispone: "La República condena todo privilegio y toda situación que tienda a quebrantar la igualdad de todos los dominicanos, entre los cuales no deben contar otras diferencias que las que resulten de los talentos y de las virtudes". De ambos principios debemos apoyarnos para regir el estado de libertad del procesado durante la fase de investigación y el juicio subsiguiente.

La interpretación del principio de igualdad de la Corte Interamericana de Derechos Humanos sienta la jurisprudencia de que "este principio de igualdad de las partes ante la ley contiene la prohibición explícita de todo tratamiento desigual y discriminatorio, de origen legal, y, en consecuencia, a no introducir en el ordenamiento jurídico, regulaciones discriminatorias, referente a la protección de los derechos reconocidos..."

A la luz de estos principios, la libertad de todo procesado es la regla y su prisión preventiva, la excepción, en toda materia, incluyéndose el lavado de activos.

Ahora bien, la prisión preventiva del imputado es una medida de coerción o cautelar que puede ser dictada en el proceso de investigación por el juez a requerimiento del Ministerio Público, que corresponde a la fase preparatoria en el nuevo proceso penal acusatorio adoptado en el ordenamiento jurídico dominicano, a la entrada en vigencia plena del nuevo Código. Y para los casos sometidos al amparo del Código de Procedimiento Criminal, a la jurisdicción de instrucción, que con la aplicación del art. 3 de la Constitución Política dominicana y la citada Resolución No.1920, ha quedado constitucionalizado.

Durante el proceso de investigación al procesado en materia de lavado de activos, el Ministerio Público puede solicitar y el juez ordenar, mediante resolución motivada, la prisión preventiva cuando concurran todas las circunstancias siguientes:

1. Existen elementos de prueba suficientes para sostener, razonablemente, que el imputado es, con probabilidad, autor o cómplice de una infracción, en la especie, de lavado de activos;

2. Existe peligro de fuga basado en una presunción razonable, por apreciación de las circunstancias del caso particular, acerca de que el imputado podría no someterse al procedimiento (Artículo 227 del Código Procesal Penal);

3. La prisión preventiva en el caso de lavado de activo, tiene una duración máxima de dieciocho meses (Art. 370.2 del Código Procesal Penal);

El peligro de fuga es el principal criterio a que debe atenerse el juez o tribunal para aplicar la medida de coerción de prisión preventiva, tomándose en cuenta las circunstancias siguientes: 
negocios o trabajo y las facilidades para abandonar el país o permanecer oculto. La falsedad o falta de información sobre el domicilio del imputado constituye presunción de fuga;

2. La pena imponible al imputado en caso de condena;

3. La importancia del daño que debe ser resarcido y la actitud que voluntariamente adopta el imputado ante el mismo.

4. El comportamiento del imputado durante el procedimiento o en otro anterior, en la medida que indique su voluntad de someterse o no a la persecución penal.

La prisión preventiva es aplicable cuando no pueda evitarse razonablemente la fuga del imputado, mediante la imposición de una o varias de las medidas de coerción personales que indicaremos más adelante (Art. 234 del Código Procesal Penal).

No puede ordenarse la prisión preventiva en los siguientes casos cuando se trate de:

1. Una persona mayor de setenta años, si se estima que en caso de condena no le es imponible una pena mayor de cinco años de privación de libertad;

2. Mujeres embarazadas;

3. Madres durante la lactancia; y

4. Personas afectadas por una enfermedad grave y terminal.

La prisión preventiva queda sometida a un régimen de revisión obligatoria cada tres meses e independiente del derecho del imputado de solicitar la revisión de esta medida de coerción, en cualquier época, cuando estime que han cambiado los presupuestos en que se apoye la misma. El juez examina los supuestos de la prisión preventiva y, según el caso, ordena su continuación, modificación o sustitución por otra medida de coerción cuya revisión se produce en audiencia oral con citación a todas las partes y el juez decide inmediatamente en presencia de los que asistan. (Art. 239 del Código Procesal Penal).

\section{Medidas cautelares en la instrucción o fase preparatoria del proceso penal}

Se definen como medidas de coerción, también denominadas cautelares, "aquellas actuaciones jurisdiccionales, llevadas a cabo en el seno del procedimiento, restrictivas de ciertos derechos de los presuntos responsables de los hechos objeto de investigación o enjuiciamiento, que persiguen asegurar la más correcta celebración del juicio y la eficacia de la condenación que definitivamente recaiga. ${ }^{1}$ 
Art. 222, de conformidad con el cual "toda persona tiene derecho a la libertad y a la seguridad personal. Las medidas de coerción tienen carácter excepcional y sólo pueden ser impuestas mediante resolución judicial motivada y escrita por el tiempo absolutamente indispensable y a los fines de asegurar la presencia del imputado en el procedimiento", estas medidas están sometidas ante la jurisdicción de instrucción a los principios y garantías del debido proceso en la medida que tutelan los derechos constitucionales del procesado.

\subsection{Medidas personales}

Las medidas de coerción están clasificadas en el Código Procesal Penal como personales y reales. Las primeras son las que afectan, de manera principal, al estatuto de libertad, o sea, al principio de libertad y de seguridad personales del imputado como a su derecho constitucional de la libertad de tránsito (Artículos 8, numeral 2, letras b, y e y numeral 4 de la Constitución de la República Dominicana).

Las medidas de coerción reales son aquellas que recaen sobre el patrimonio del procesado para garantizar la reparación de los daños y perjuicios provocados por el hecho punible y el pago de las costas del procedimiento. Las partes pueden formular al juez la solicitud de embargo, inscripción de hipoteca judicial u otras medidas conservatorias previstas por la ley civil, y el Ministerio Público puede solicitar estas medidas para garantizar el pago de las multas imponibles o de las costas o cuando la acción civil le haya sido delegada (art. 243 del Código Procesal Penal). El trámite de las medidas de coerción se rige, en cuanto sean aplicables, por las reglas del Código de Procedimiento Civil y la legislación especial.

Las medidas de coerción personales están formuladas en el Art. 226 del referido Código Procesal Penal, como sigue:

1. La presentación de una garantía económica suficiente;

2. La prohibición al procesado de salir sin autorización del país, de la localidad en la cual reside o del ámbito territorial que fije el juez;

3. La obligación de someterse al cuidado o vigilancia de una persona o institución determinada, que informa regularmente al juez;

4. La obligación de presentarse periódicamente ante el juez o ante la autoridad que el designe;

5. La colocación de localizadores electrónicos, sin que pueda mediar violencia o lesión a la dignidad o integridad física del imputado;

6. El arresto domiciliario del imputado, en su propio domicilio o en custodia de otra persona, sin vigilancia alguna o con la que el juez disponga; 


\section{La prisión preventiva.}

Para la aplicación de las medidas de coerción es necesario que existan suficientes elementos de prueba para sostener, razonablemente, que el procesado es con probabilidad autor o cómplice del delito que se le imputa; existe peligro de fuga, según los criterios desenvueltos precedentemente, y naturalmente que el tipo penal esté sancionado con pena privativa de libertad.

Las medidas de coerción se aplican a solicitud del Ministerio Público o del querellante, y el juez puede imponer una sola de las medidas de coerción previstas en este código o combinar varias de ellas, según resulte adecuado al caso, y expedir las comunicaciones necesarias para garantizar su cumplimento. Cuando se ordene la prisión preventiva, no puede combinarse con otras medidas de coerción.

En ningún caso el juez está autorizado a aplicar estas medidas desnaturalizando su finalidad, ni a imponer otras más graves que las solicitadas o cuyo cumplimiento resulta imposible. (Art. 228 Código Procesal Penal).

El tipo penal de lavado de activos, en el nuevo Código Procesal Civil, cae en la categoría de "Procedimiento para Asuntos Complejos", por presentar las características de la "delincuencia organizada", además del elevado número de imputados o victimas que pueda involucrar, por lo que el Ministerio Público, durante el procedimiento preparatorio y antes de presentarse cualquier requerimiento conclusivo, como es la apertura a juicio mediante la acusación, debe solicitar al juez de la instrucción, que autorice, mediante resolución motivada, la aplicación de las normas especiales para el conocimiento del procedimiento para asuntos complejos. Esto tiene diversas consecuencias jurídicas como lo es, en el aspecto de las medidas coercitivas, la duración de la prisión preventiva aumentada a dieciocho (18) meses en lugar de doce (12) meses como en el procedimiento penal ordinario.

En el caso específico de la libertad provisional bajo fianza, en la Ley No. 72-02 sobre Lavado de Activos Provenientes del Tráfico llícito de Drogas y Sustancias Controladas y Otras Infracciones Graves, del 7 de junio del 2002, en su Art. 30 establece que no tendrán aplicación las leyes que establecen la libertad provisional bajo finaza, la libertad condicional y el perdón de la pena. En igual sentido se pronuncia la Ley 50-88 sobre Drogas y Sustancias Controladas de la República Dominicana vigente.

Estas leyes del ordenamiento jurídico dominicano están sometidas a la primacía de las disposiciones constitucionales, de los tratados internacionales y a sus interpretaciones por los órganos jurisdiccionales creados por éstos y, por consiguiente, al control difuso de su constitucionalidad por los jueces dominicanos, de conformidad con los artículos 3 y 46 de la Constitución de la República Dominicana; cuyas regulaciones prevalecen siempre sobre la ley; al Estado Dominicano aceptar, desde el 19 de febrero de 1999, la competencia 
de la Corte Interamericana de Derechos Humanos, y las interpretaciones de sus órganos sobre todos los casos de aplicación de la Convención Interamericana sobre Derechos Humanos (Pacto de San José) son vinculantes.

\subsection{Medidas sobre bienes: incautación y decomiso}

La incautación y el decomiso como figuras jurídicas vinculadas al proceso penal no constituyen términos jurídicos equivalentes². No obstante, una y otra se encuentran estrechamente vinculadas.

La incautación constituye una medida cautelar que se adopta en el curso de las investigaciones de un proceso penal, con el objeto de evitar la pérdida, deterioro o distracción de los bienes que son susceptibles de ser decomisados, por haber sido utilizado, o ser el producto de una infracción penal.

La Convención de Viena de 1988, en su capítulo de definiciones denomina indistintamente a la "incautación" como "embargo preventivo", refiriendo que esta medida implica "la prohibición temporal de transferir, convertir, enajenar o mover bienes, o la custodia o el control temporal de bienes por mandamiento expedido por un tribunal o por una autoridad competente".

El Reglamento Modelo elaborado por el Grupo de Expertos de Lavado de Activos de la Comisión Interamericana para el Control del Abuso de Drogas (CICAD), de la Organización de Estados Americanos (OEA), en su Art. 1, utiliza igual denominación y definición que el utilizado por la Convención de Viena de 1988.

Por su parte, el decomiso es definido como "la privación con carácter definitivo de algún bien por decisión de un tribunal o de otra autoridad competente". 3

El carácter definitivo del decomiso es lo que lo distingue de la incautación, que "es una medida cautelar real que se puede acordar en cualquier fase del procedimiento, medida caracterizada por su carácter provisional e instrumental. Provisional, en tanto que puede resultar alterada en cualquier momento del proceso desapareciendo automáticamente en caso de que la sentencia sea absolutoria y convirtiéndose en definitiva si la sentencia condenase al sujeto. Es instrumental, en la medida en que no es un fin en sí misma, sino que es un medio para alcanzar un fin: que la sentencia que se dicte pueda ejecutarse". 4

La ausencia de un mecanismo cautelar como la incautación podría conducir en los procesos de lavado de activos a que bienes susceptibles de ser decomisados a favor del Estado sean transferidos en el comercio jurídico a terceros de buena fé, no responsables del delito, imposibilitándose en consecuencia la posibilidad de que el órgano jurisdiccional disponga posteriormente su comiso a favor del Estado. 


\subsection{La incautación en la Ley 72-02}

La Ley 72-02, sobre Lavado de Activos, no solo define en su Art. 1, numeral 5, la incautación5, sino que precisa que uno de sus objetivos es lo relativo a las medidas cautelares que deben ser adoptadas en el curso de los procesos penales por lavado de activos6, dedicándole la Sección II del Capitulo III7.

El Art. 9 de la Ley 72-02, faculta al Ministerio Público y a los Tribunales del Orden Judicial para ordenar, en el curso de las investigaciones de una infracción de lavado de activos, sin necesidad de notificación y audiencia previa, la incautación de los bienes productos del lavado de activos hasta tanto intervenga una sentencia con autoridad de cosa irrevocablemente juzgada. Asimismo, están investidos con la facultad de disponer la inmovilización de los fondos que se encuentren en manos de las actividades empresariales, financieras y comerciales sujetas al cumplimiento de obligaciones de prevención del lavado de activos ${ }^{8}$, entre las que se encuentran las entidades de intermediación financiera, las casas de cambio, las compañías de seguros, los casinos, etc.

\subsection{El decomiso en la Ley $72-02$}

El Art. 1, numeral 4 de la Ley 72-02, dispone que se entiende por decomiso "Ia privación con carácter definitivo de algún bien por decisión de un tribunal competente".

Por su parte, la Sección IV del Capítulo II de la Ley, reglamenta lo relativo al decomiso de bienes y el destino que debe dárseles a los mismos.

En cuanto al decomiso, el Art. 31 de la Ley 72-02 dispone que cuando "una persona sea condenada por violación a la presente ley, el tribunal ordenará que los bienes, productos e instrumentos relacionados con la infracción sean decomisados", precisando que la "orden de decomiso especificará la propiedad y contendrá los datos correspondientes para identificar y localizar la misma". 9

\subsection{Bienes susceptibles de estas medidas}

Los bienes que son susceptibles de ser decomisados en los procesos de lavado de activos están conformados por aquellos "activos de cualquier tipo, corporales e incorporales, muebles e inmuebles, tangibles e intangibles" que se obtengan o deriven directa o indirectamente del delito previo.

\subsection{Decomiso parcial. Situación de los bienes mezclados.}

Es posible que la persona que forma parte, en calidad de imputado, de un proceso penal por lavado de activos 
mezcle los recursos originados en la actividad delictiva con otros recursos líquidos obtenidos de forma lícita, 0 adquiera parcialmente, con el producto de la comisión de una infracción grave, activos mobiliarios o inmobiliarios. En estas hipótesis se produce lo que en la doctrina y la legislación sobre la materia se denominan los bienes mezclados.

El Párrafo II, del Art. 31 de la Ley 72-02, sobre Lavado de Activos, regula esta situación disponiendo que "cuando las propiedades obtenidas o derivadas, directa o indirectamente, de un delito han sido mezcladas con propiedades adquiridas de forma lícita, el decomiso de éstas será ordenado por el valor de los bienes productos o instrumentos del delito".

\subsection{Comiso Sustitutivo y del valor por sustitución}

Resulta muy frecuente en los procesos de lavado de activos que los bienes, productos o instrumentos derivados del delito no se encuentren en el patrimonio del imputado por haber sido destruidos, o sencillamente hayan sido transferidos a terceros de buena fé, imposibilitando su decomiso a favor del Estado.

De ahí que la legislación prevé esta realidad a fin de que en estos casos bienes del procesado de origen lícito puedan ser objeto de decomiso en sustitución de aquellos que, aunque provenientes directamente del lavado de activos objeto de proceso, no pueden ser decomisados por las circunstancias indicadas en el párrafo anterior.

La Ley 72-02, sobre lavado de activos, recoge esta situación al disponer en su Art. 32 que "cuando cualquiera de los bienes, productos o instrumentos, como resultado de cualquier acto u omisión del condenado, no pudieren ser decomisados, el tribunal ordenará el decomiso de cualesquiera otros bienes del condenado, por un valor equivalente u ordenará al mismo que pague una multa por dicho valor". 10

Dos son las situaciones contempladas por el texto legal anteriormente citado. La primera, el decomiso de cualesquiera otros bienes del condenado por un valor equivalente, se corresponde con la figura del comiso sustitutivo. La segunda alternativa es la de la imposición de una multa por el valor que tenían los bienes cuyo decomiso directo se ha imposibilitado, lo que constituye el comiso por sustitución o comiso del valor sustitutorio.

\section{La situación de los terceros de buena fé}

Las medidas provisionales o definitivas sobre bienes con motivo de un proceso penal por lavado de activos, en 
principio sólo son aplicables a los bienes que tengan su origen en los beneficios generados por una actividad ilícita, que sean de la propiedad de los procesados.

Cuando estos bienes son de la titularidad de un tercero de buena fé, es decir, una persona que sea ajena al lavado de activos objeto del proceso, no podrá ser objeto de decomiso.

La ley sobre la materia, aunque persigue como un objetivo de política criminal privar a los lavadores de los bienes originados en la comisión de una infracción grave, es respetuosa del tráfico comercial legítimo de los bienes. De ahí, que en aquellos casos en que no se pueda acreditar una participación del titular de esos bienes en la específica actividad delictiva objeto de juzgamiento la sentencia que intervenga no podrá ordenar su decomiso.

La Convención de Viena de 1988, en el párrafo 8 del Art. 5, señala de forma expresa a propósito del decomiso que "lo dispuesto en el presente artículo no podrá interpretarse en perjuicio de los derechos de terceros de buena fé".

La Ley 72-02, de junio del año 2002, dedica la Sección V, de su Capitulo III (artículos 34 a 37), a la situación de los terceros de buena fé.

El artículo 35, de la Ley 72-02, dispone que dentro de los treinta (30) días siguientes a la incautación de un bien en un proceso de lavado de activos, el Ministerio Público dispondrá su publicación una vez por semana, durante tres (3) semanas consecutivas, en un diario de amplia circulación nacional, a fin de que todos aquellos que pudieran alegar un interés legítimo sobre los mismos se presenten a hacer valer sus derechos.

El artículo 36 de la Ley de Lavado de Activos, por su parte, reglamenta los casos en los cuales el Ministerio Público podrá devolver un bien previamente incautado:

(a) El reclamante tiene un interés jurídico legítimo respecto de los bienes, productos o instrumentos;

(b) Al reclamante no puede imputársele ningún tipo de participación, colusión o implicación con respecto a un delito de tráfico ilícito u otra infracción grave, objeto del proceso;

(c) El reclamante desconocía la adquisición o el uso ilegal de los bienes, productos o instrumentos, 0 bien teniendo conocimiento de esto, no consintió voluntariamente en la adquisición o uso ilegal de los mismos;

(d) El reclamante no adquirió derecho alguno a los bienes, productos o instrumentos de la persona 
procesada en circunstancias que llevaran razonablemente a concluir que el derecho sobre aquello le fue transferido a los efectos de evitar el eventual decomiso posterior de los mismos; y

(e) El reclamante hizo todo lo razonable para impedir el uso ilegal de los bienes, productos o instrumentos.

Por otra parte, constituye un presupuesto esencial para que un tribunal apoderado de un proceso de lavado de activos pueda ordenar el decomiso de un bien de la titularidad de un tercero ajeno a la prevención penal, que el mismo sea citado a fin de que haga valer sus derechos. ${ }^{11}$

El Tribunal Constitucional y el Tribunal Supremo Español en distintas decisiones han resaltado la necesidad del respeto al derecho de defensa del tercero titular de los bienes como condición sine qua non para que el Tribunal apoderado de un proceso en relación a tráfico de drogas o lavado de dinero pueda decretar el decomiso de estos bienes a favor del Estado (STC 123/1995; SSTS 17 de septiembre de 1991 y 17de diciembre de 1996).

La Sala Tercera de la Corte Suprema de Justicia de Costa Rica mediante su Voto 174, Folio 95, del 24 de marzo de 1995, decidió casar una sentencia ya que dispuso el comiso de un vehículo registrado a nombre de un tercero a quien no se hizo comparecer en el curso del proceso, por lo que no podría resultar afectado a consecuencia de esa omisión.

En esta interesante decisión el citado tribunal señala que "corresponde aclarar que aún cuando el artículo 31 ibídem faculta -entre otros supuestos- a los tribunales de justicia para proceder al decomiso o embargo de "Ios bienes muebles o inmuebles, los vehículos, instrumentos, los equipos y demás objetos que se utilicen en la comisión de los delitos previstos en esta ley..." esto no puede interpretarse como una autorización irrestricta para proceder a la incautación de esos bienes en general, sino que debe demostrarse, además del uso en la actividad ilícita -acorde con la globalidad del ordenamiento jurídico- la propiedad de los bienes. Lo anterior significa que no basta con que se tenga por acreditada la utilización del vehículo para cometer el ilícito, para que pueda decretarse el comiso de manera irregular, sino que deberá probarse mediante documento idóneo la titularidad sobre el mismo, puesto que podría tratarse de bienes pertenecientes a terceros, sin relación alguna con los hechos delictivos sobre los que se pronunciaría el tribunal y en virtud de su disposición final se vería afectado el derecho de propiedad con apoyo en una responsabilidad objetiva".

\section{Destino de los bienes decomisados}

Se ha señalado como uno de los objetivos de política criminal sobre la materia el destinar el producido con los bienes decomisados a promover las estrategias de prevención del uso de drogas. 
Como ha dicho Javier Zaragoza Aguado, "Ia idea central que debe servir para el adecuado enfoque de este problema es que existen miles y miles de víctimas afectadas por estas actividades delictivas, y que ante esa situación de "socialización del daño" es necesario y prioritario responder con la "socialización del beneficio" obtenido con la producción de este daño, de modo y manera que todos aquellos productos y ganancias procedentes del crimen reviertan a favor de quienes son víctimas impersonales y anónimas de esas actividades delictivas. Es, sin duda, una idea novedosa pero que responde a una tendencia cada vez más asumida en el derecho comparado: la lucha contra la droga debe ser financiada en la mayor medida posible con los beneficios y ganancias derivados de la actividad de tráfico ilegal de drogas y de otras actividades con ella relacionadas".

El legislador dominicano hace una distinción cuando los bienes decomisados tienen su origen en un delito de tráfico de drogas, o en cualquier otra infracción grave.

En el primer caso dispone la siguiente distribución:

(a) Cuando se trate de bienes decomisados provenientes del tráfico ilícito de drogas, el Comité Nacional contra el Lavado de Activos los destinará de la manera siguiente:

(1) $15 \%$ (quince por ciento) para las instituciones dedicadas a la regeneración de los adictos a drogas.

(2) $50 \%$ (cincuenta por ciento) para la Dirección Nacional de Control de Drogas, para ser utilizados conforme a sus necesidades.

(3) $35 \%$ (treinta y cinco por ciento) para el Consejo Nacional de Drogas, para prevenir y educar contra el uso de las drogas.

En los demás casos:

(1) El 50\% (cincuenta por ciento) para las instituciones mencionadas en los numerales 1, 2 y 3 del acápite a) del presente artículo, en la misma proporción; y

(2) El 50\% (cincuenta por ciento) restante se destinará al Fondo General de la Nación.

\section{Los sistemas de valoración de la prueba y en particular sobre la valoración de medios de prueba en la investigación del lavado de activos}

La prueba judicial tiene por finalidad esencial acreditar la certeza de un hecho controvertido, siendo la certeza o la verdad, en el ámbito penal, de naturaleza material, o sea, la reconstrucción histórica del hecho o que esté 
tan cerca de la realidad del mismo - conforme a las leyes de la lógica, a los principios de experiencia y a los valores científicos-, que destruya toda duda razonable.

Entendemos preciso la conceptualización de valoración de la prueba judicial, entendida como la operación mental que tiene por fin conocer el mérito o valor de convicción que pueda deducirse de su contenido. Cada medio de prueba es susceptible de valoración individual y por ocasiones puede bastar uno para formar la convicción del juez. Pero lo ordinario es que se requieran varios de la misma o distinta clase para llegar a la certeza sobre los hechos discutidos en el proceso contencioso o sobre lo simplemente afirmado. ${ }^{12}$

Nos referiremos en prima facie a los criterios que crean los principales sistemas de evaluación de la prueba.

Desde el punto de vista de la libertad dada al juez para la valoración de la prueba o dependiendo de la mayor o menor atadura del juez a la ley, para la reconstrucción de la narración conforme a la norma a aplicar, pueden encontrarse dos sistemas: el de la prueba legal y el de libertad de la prueba.

\section{El sistema de la prueba legal}

Los criterios de la prueba legal están destinados a limitar el poder del juez, a sustituir al juez por el legislador y, por consiguiente, a señalarle al juez el camino en forma minuciosa. La credibilidad del medio de prueba es pesada y medida por la ley, no por el juez. No obstante ser el juez quien tiene la atribución exclusiva para admitir y valorar la prueba, dentro de los límites de su legalidad, la ley intervenía para establecer el control previo para su admisión y apreciación.

En ese sistema las normas procesales le dan al juez indicación precisa acerca de cómo tiene que estructurar la información obtenida de los medios de prueba admitidos y discutidos por las partes, o sea, que obligan al juez a estructurar la información dentro del marco legal fijado por las normas procesales. Por ejemplo, sobre el valor de los documentos: según su clasificación en auténticos, bajo firma privada y simples datos, haciendo los primeros fe máxima, hasta su inscripción en falsedad.

\section{Sistema de la libertad probatoria}

En oposición al sistema de la prueba legal, o sea aquella cuya existencia y valor probatorio están determinados taxativamente por la ley, y tiene como objeto la verdad formal, que es el caso de la prueba en materia civil, en el sistema de la libre apreciación de la prueba se le confiere al juez la potestad para determinar sobre la 
admisión de las pruebas y sobre la valoración de las mismas, dentro de los límites de la legalidad, para definir por sí mismo el valor de ellas, el grado de certeza o certidumbre para forjar su convicción. Este método también se denomina el de la certeza moral o de la íntima convicción, que ha evolucionado en el sistema acusatorio al de la sana crítica.

Con arreglo al método de la libre convicción, el juez debe examinar y apreciar todos los medios de pruebas de conformidad con su raciocinio y su conciencia. Con los principios de la experiencia y los principios científicos, en este contexto, los medios de prueba tienen por lo general un contenido material, del cual deduce sus inferencias o consecuencias el juez, para la obtención de la verdad material o judicial.

"... el objeto de la prueba es la obtención de la verdad material, esto es llegar a conocer que es lo que en realidad ocurrió en el mundo fenoménico, cómo y de qué manera se desarrollaron los acontecimientos, de forma que el resultado del juicio sería un calco de lo ocurrido en el momento de la comisión".13

La verdad material a que tiende la actividad probatoria del juez, que en última instancia debe formarse opinión para absolver o para condenar a un ser humano, debe ser como asevera el Prof. Dr. Miguel Langón Cuñarro: "...llegar a obtener la verdad procesal (cuanto más cercana a la material mejor), es decir a aquel estado probatorio, basado en los resultados de la encuesta, que permitan en conciencia, de buena fe, sin dudas, dictar un veredicto de culpabilidad, más allá de toda duda razonable, que fluya naturalmente de la causa y que pueda tomarse como la "verdad" tal como se presentó el caso en juicio".14

Y continúa afirmando que: "Ia búsqueda de una verdad material a ultranza puede conducir al sistema inquisitivo, a la tortura y a la búsqueda a toda costa de la confesión, visto que, en definitiva, en no pocas ocasiones, sólo el delincuente puede saber exactamente qué es lo que pasó".15

El principio de la libertad de prueba, propio del modelo acusatorio en su evolución actual, ha sido el adoptado en el sistema procesal penal dominicano, según se ha instituido en el Art.170 del Código Procesal Penal que establece:

"Los hechos punibles y sus circunstancias pueden ser acreditados mediante cualquier medio de prueba permitido, salvo prohibición expresa".

Y esa prohibición legal se consigna en el Art. 167 que establece la exclusión probatoria que será analizada más adelante.

El desarrollo del derecho procesal contemporáneo parte de la premisa del principio de la libertad de prueba: que 


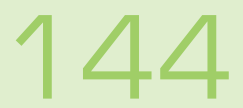

ASPECTOS DOGMÁTICOS, CRIMINOLÓGICOS Y PROCESALES DEL LAVADO DE ACTIVOS

pueda ser utilizada en juicio, o sea, ser presentada por las partes procesales; y que el juez admita y valore todo tipo de prueba, ya sea nominada o no en el Código Procesal Penal y en leyes especiales y en los tratados y convenios internacionales adoptados por el ordenamiento jurídico dominicano, así como en sus interpretaciones por los órganos jurisdiccionales creados por éstos, cuyas normas y principios son de aplicación directa e inmediata, en los casos sometidos a la jurisdicción de los tribunales y prevalecen sobre la ley, conforme la Constitución de la República Dominicana, en su artículo 3, que establece:

"La República Dominicana reconoce y aplica las normas del Derecho Internacional general y americano en la medida en que sus poderes públicos las hayan adoptado..."16

Y complementado con el Art. 10 de dicha Constitución que dispone;

"La enumeración contenida en los artículos 8 y 9 no es limitativa, y por consiguiente, no excluye otros derechos y deberes de igual naturaleza".

En consecuencia, quedan incluidos con rango constitucional los derechos humanos contenidos en los instrumentos internacionales integrados en "el bloque de constitucionalidad", asumidos y reconocidos en la Resolución de la Suprema Corte de Justicia No.1920-2003, del 13 de noviembre del 2003, con la finalidad de darles vigencia efectiva a los derechos y garantías procesales, y que textualmente dice:

"Primero: Reconoce y asume los siguientes principios fundamentales: 1. El principio del juicio previo; 2. El principio del juez natural o regular; 3. La imparcialidad y la independencia: 4. La legalidad de la sanción, condena y del proceso; 5. el plazo razonable; 6. El principio de la única persecución o "non bis in idem": 7. Garantía de respeto a la dignidad de la persona; 8. Igualdad ante la ley; 9. Igualdad entre las partes en el proceso; 10. Derecho a no declarar en contra de sí mismo o de no autoincriminación; 11.La presunción de inocencia; 12. Estatuto de libertad; 13. Personalidad de la persecución; 14. El derecho a la defensa; 15. Formulación precisa de cargos; 16. El derecho al recurso efectivo; 17. La separación de funciones; 18. La obligación de decidir; 19. Motivación de decisiones; 20. Legalidad de la prueba; y, 21. Derecho a la defensa o asistencia técnica, tal como se ha descrito más arriba como parte integrante del debido proceso y dispone su aplicación inmediata en todos los tribunales del país".17

La supremacía de la Constitución y los tratados es el primer principio consagrado en el Art. 1 del Código Procesal Penal que establece: "Los tribunales, al aplicar la ley, garantizan la vigencia efectiva de la Constitución Política de la República y de los tratados internacionales y sus interpretaciones por los órganos jurisdiccionales creados por éstos, cuyas normas y principios son de aplicación directa e inmediata en los casos sometidos a su jurisdicción y prevalecen siempre sobre la ley". ${ }^{18}$ 
Merece un comentario especial el principio de la legalidad de la prueba, establecido como el principio 26 del Código Procesal Penal y el de la libertad de la prueba en el Art. 170 más arriba trascrito:

"Art. 26. Legalidad de la prueba. Los elementos de prueba sólo tienen valor si son obtenidos e incorporados al proceso conforme a los principios y normas de este código. El incumplimiento de esta norma puede ser invocado en todo estado de causa y provoca nulidad del acto y sus consecuencias, sin perjuicio de las sanciones prevista por la ley a los autores del hecho". 19

La libertad de prueba tiene como límite la ilegitimidad e ilicitud de la misma, lo que se califica como exclusión probatoria, en el artículo 167 del referido Código Procesal Penal que textualmente expresa:

"No puede ser apreciada para fundar una decisión judicial, ni utilizada como presupuesto de ella, la prueba recogida con inobservancia de las formas y condiciones que implique violación de derechos y garantías del imputado, previsto en la Constitución de la República, los tratados internacionales y este código. Tampoco pueden ser apreciadas aquellas pruebas que sean la consecuencia directa de ellas, salvo si se ha podido obtener otra información licita que arroje el mismo resultado.

Asimismo, no pueden ser valorados los actos cumplidos con inobservancia de la forma que impidan el ejercicio del derecho a la tutela de la victima o impidan el ejercicio de los deberes del ministerio público, salvo que el defecto haya sido convalidado". 20

Entendiéndose, por consiguiente, como ilegitimidad de los elementos de prueba que su obtención e incorporación al proceso sean hechas en violación a los valores y principios constitucionales y de los instrumentos internacionales sobre derechos humanos, "bloque de constitucionalidad", cuya infracción tiene como sanción la nulidad del acto y de sus consecuencias, de conformidad con el control constitucional difuso, vinculante para todos los jueces del orden judicial y consagrado en el Art. 46 de la Constitución de la República Dominicana que estable:

"Son nulos de pleno derecho toda ley, decreto, resolución, reglamento o acto contrario a esta Constitución".21

Por tanto, toda prueba ilegítima se torna en ilícita si es el resultado de un medio legalmente inadmisible como lo es, por ejemplo, el acta del allanamiento realizado sin la presencia y dirección del Ministerio Público, lo que constituiría una violación del domicilio, derecho constitucional, y al procedimiento legal establecido en el nuevo Código Procesal, en sus artículos del 179 al 184 inclusive, que requiere la autorización de la autoridad judicial competente; así como la interceptación de las llamadas telefónicas sin la autorización judicial. Es, además, prototipo de prueba ilícita la confesión obtenida en sede administrativa (o policial) en violación al principio 
constitucional de que "nadie podrá ser obligado a declarar contra sí mismo" (Art. 8, inciso 2, letra i) y en violación a la Convención Interamericana sobre Derechos Humanos, en su artículo 7.3, que establece: "La confesión del inculpado solamente es válida si es hecha sin coacción de ninguna naturaleza"; y asimismo, en el Pacto Internacional de Derechos Civiles y Políiticos, en su artículo 14.3.g: "A no ser obligado a declarar contra sí mismo ni a confesarse culpable"; o sea, mediante el empleo de coacción material o síquica.

Como considerara un autor antes citado, en "... el principio de la libertad de la prueba: las partes pueden acreditar sus puntos de vista del modo que entiendan conveniente, salvo que constituyera un mecanismo ilegal, violatorio de derechos, un ilícito o prueba prohibida. 22 Por otra parte, "La libertad de empleo de todos los medios de prueba disponible, permite también introducir en juicio la prueba trasladada, de especial importancia en sede de cooperación jurídica internacional, y en la lucha contra toda forma de delincuencia organizada especialmente si ella pertenece a la delincuencia transnacional" 23

En consecuencia, la prueba ilícita es toda prueba contraria al ordenamiento constitucional, Convencional o legal de un país determinado.

El Dr. Miguel Langón Cuñarro, se refiere a los poderes de "policía del proceso"24 que tiene el Juez, para desechar la prueba inconducente, impertinente o dilatoria, potestades disciplinarias y ordenadoras del juicio que deben ser usadas con toda prudencia y cautela. Esta policía del proceso es lo que se califica en nuestro Código Procesal Penal como los poderes sobre la "admisibilidad" de la prueba, que está sujeta a su referencia directa 0 indirecta con el objeto del hecho investigado (pertinencia) y a su utilidad para descubrir la verdad (conducente), por lo que el Juez o tribunal puede restringir los medios de prueba ofrecidos que resulten manifiestamente sobreabundantes (dilatorios), y también puede prescindir de la prueba cuando ésta sea ofrecida para acreditar un hecho notorio que es definido como "aquellos que por su general y pública divulgación no necesitan ser probados. 25 (Art. 171 del Código Procesal Penal).

En resumen, el principio rector en la actividad probatoria es, pues, el de legalidad, según el cual los elementos de prueba sólo tienen valor si son obtenidos e incorporados al proceso conforme a los principios y normas constitucionales y de los instrumentos internacionales relativos al proceso judicial, entre éstos la Convención Interamericana sobre Derechos Humanos o Pacto de San José, del 22 de noviembre de 1969, aprobada por el Congreso Nacional el 25 de diciembre de 1977; del Pacto Internacional sobre Derechos Civiles y Políticos, del 16 de diciembre de 1966, aprobado por el Congreso Nacional el 27 de octubre de 1977; el instrumento de aceptación de la competencia de la Corte Interamericana de Derechos Humanos de fecha 19 de febrero de 1999 ; y del Código Procesal Penal y cuyo incumplimiento de dicha norma puede ser invocado en todo estado de causa y provoca la nulidad del acto y sus consecuencias (Art. 26 Código Procesal Penal) y en el Art. 167 que establece, como consecuencia del principio de la legalidad de la prueba, que solo pueden ser valorados como 
elementos de prueba:

(a) Si han sido obtenidos por un medio lícito y conforme a las disposiciones del Código Procesal Penal;

(b) La violación a estos principios trae como secuela que no pueden ser apreciados para fundar una decisión judicial ni utilizados como presupuestos;

(c) Son ilegítimas las pruebas recogidas con inobservancia de las formas y condiciones que impliquen violación de derechos y garantías constitucionales, incluidas las contenidas en tratados internacionales y el Código Procesal Penal dominicano;

(d) No pudiéndose tampoco apreciar aquellas pruebas que sean la consecuencia directa de la violación de principios constitucionales y del bloque de constitucionalidad; y

(e) Con la excepción de si se ha podido obtener otra información lícita que arroje el mismo resultado.

En consecuencia, "la producción de prueba en contradicción a lo que establecen las normas, determina la ilicitud de la misma, y la ilicitud de la prueba puede llevar a la anulación del proceso, y, eventualmente, lisa y Ilanamente a una sentencia de absolución."26

Procede que se analice en este momento la "teoría del fruto del árbol venenoso", según la cual se contamina el proceso y lo anula, y que permite y obliga a apartar del proceso, por lo menos, a las pruebas ilegalmente obtenidas, si es que no lo vicia por completo, teoría que ha sido adoptada de manera atenuada en el Código Procesal Penal, ya que deja abierta la salvedad de "si ha podido obtener otra información lícita que arroje el mismo resultado". 27

En materia de lavado de activos, así como en delitos de igual naturaleza por su gran lesividad social, referentes a la criminalidad organizada y transnacional, al tráfico de drogas, "la teoría del fruto del árbol venenoso" ha sido objeto de diferentes posiciones doctrinales como la radical o garantista, que propugna por la inadmisibilidad absoluta de la prueba obtenida y nulidad del proceso, y en el caso del ordenamiento jurídico dominicano, toda prueba obtenida en violación a principios constitucionales es nula de nulidad absoluta, ya que la misma entra en el control difuso de la constitucionalidad, como ya se ha analizado, en la especie, de los actos contrarios a la Constitución, sancionados en su artículo 46; y en el Art. 167 del Código Procesal Penal, que regula la exclusión probatorio de elementos de prueba, sin que se extienda, necesariamente, a la nulidad del proceso o la contaminación del proceso, ya que se prevé, como se ha expresado con anterioridad, la posibilidad de otra información lícita que arroje el mismo resultado.

Según la opinión del Dr. Miguel Langón Cuñarro, "la doctrina alemana parece acercarse a la postura más aceptable en este punto y tiene que ver con los delitos particularmente graves, como ... la criminalidad 
organizada, el tráfico de droga, en cuyos casos por su excepcionalidad, por la importancia del bien jurídico lesionado o puesto en riesgo, por consideración a la opinión pública y por el escándalo que provocaría la impunidad de estos crímenes, en mérito a lo que no pocos advertirían como meros "tecnicismos" se llega a admitir el ingreso de la prueba ilícita, en función del principio de proporcionalidad para proteger los valores esenciales de la comunidad (casos de toma de rehenes, terrorismo, etc.); y justifica la anterior posición con las ideas siguientes: " Este principio de proporcionalidad es visto como un derivado del estado de derecho, como un criterio válido de razonabilidad, cuando fuere éste el único medio de proteger bienes de mayor valor comparativo para evitar resultados desproporcionados, injustos o repugnantes". ${ }^{28}$

En el ordenamiento jurídico dominicano los principios y garantías constitucionales y los derechos humanos internacionales, nacidos de instrumentos internacionales, son de jerarquía constitucional y, por tanto, de aplicación imperativa, directa e inmediata (self execution).

Lo anteriormente analizado está conforme con la Convención de Viena en su artículo 2 al regular el alcance de esta Convención, en cuyo inciso 1) reconoce que: el propósito de esta Convención es promover la cooperación entre las partes a fin de que puedan hacer frente con mayor eficacia a los diferentes aspectos del tráfico ilícito de estupefacientes y sustancias psicotrópicas que tenga una dimensión internacional y en el cumplimiento de las obligaciones contraídas en virtud de esta Convención las Partes adoptarán las medidas necesarias en el orden legislativo y administrativo de conformidad con las disposiciones fundamentales de sus respectivos ordenamientos jurídicos internos; 2) Las Partes cumplirán sus obligaciones derivadas de la presente Convención de manera que concuerde con los principios de la igualdad soberana y de la integridad territorial de los Estados y de la no intervención en los asuntos internos de otros Estados; y 3) Una Parte no ejercerá en el territorio de otra Parte competencias ni funciones que hayan sido reservadas exclusivamente a las autoridades de esa otra Parte, por su derecho interno.

\section{Sana crítica}

Para Eugenio Florián en el transcurso de la valoración de la prueba, según el sistema de la libertad de apreciación, es utilizable el método de la investigación histórica, que tiene por meta la comprobación de la verdad: el encuadramiento del hecho en el Derecho, lo que implica una operación lógica, la absorción del presupuesto de hecho en el supuesto de derecho, o sea, la subsunción. 29

Además, la investigación judicial es eminentemente sicológica, por tratarse de juzgar a un hecho humano, por lo que el juez debe apoyarse en los criterios sicológicos, que pueden aportar nuevos y preciosos factores para la apreciación de los elementos de prueba. De este modo, la investigación judicial se remonta a las cimas del razonamiento y se expande en el dominio de la psique humana. Así, el objeto del convencimiento del juez, 
luego de la libre operación probática, es determinar la existencia o inexistencia de la imputación.30

Siguiendo el orden de ideas de Eugenio Florián: "las pruebas se aprecian de acuerdo con el raciocinio y la conciencia."

El libre convencimiento o íntima convicción debe combinarse con los fines del proceso y en este se trata de obtener que la apreciación de las pruebas se haga con arreglo a la verdad, el método del libre convencimiento debe siempre fundarse en pruebas lícitas.

Esas reglas de la sana crítica constituyen, pues, "un estándar jurídico", un criterio permanente y general para la valoración de la prueba judicial, pero no son inflexibles ni estáticas, porque son tomadas del normal comportamiento social e individual, que está sujeto a la ley de la evolución cultural, técnica, científica, moral y económica. Su naturaleza y flexibilidad son similares a las de "las reglas o máximas de la experiencia", que sirven para la formación del criterio del juez y de las partes en la tarea de conocer los hechos a través de la prueba aportada y para llenar su deficiencia, por lo cual creemos que aquellas son una especie de éstas, que se refieren a la valoración de la prueba y son razones especiales para su mejor entendimiento.

Por eso las reglas o máximas de experiencia sirven al Juez para rechazar las afirmaciones del testigo o la confesión de la parte, o lo relatado en un documento, o las conclusiones que se pretenden obtener de los indicios, y hasta el dictamen de peritos, cuando están en contradicción con ellas.

En el aspecto de la valoración de la prueba se advertirá que el grado y límite de la fuerza o valor probatorio de los medios de pruebas admitidos y sometidos a los principios, específicamente a los de la legalidad, oralidad, publicidad e inmediatez, no tienen siempre un mismo grado de eficacia probatoria.

La intensidad de la fuerza o eficacia probatoria resultante de las operaciones mentales requeridas para su apreciación, será proporcional al efecto que ella producirá en la conciencia del juez. ${ }^{31}$

Es ilustrativo citar al doctrinario Framarino dei Malatesta cuando resume las distintas fases por la que transcurre el juez en su actividad de lograr su convicción: "En estado de ignorancia, es decir, de ausencia de todo conocimiento; en estado de duda, en sentido estricto, que es conocimiento alternativo, que encierra en sí, por igual el sí y el no; en estado de probabilidad, o sea de predominio del conocimiento afirmativo; y en estado de certeza, que es el conocimiento afirmativo triunfante." 32

El nuevo Código Procesal Penal en su Art. 172, respeto a la valoración de la prueba establece lo siguiente: "EI juez o tribunal valora cada uno de los elementos de prueba, conforme las reglas de la lógica, los conocimientos 
científicos y las máximas de la experiencia y está en la obligación de explicar las razones por las cuales se les otorga determinado valor, con base a la apreciación conjunta y armónica de toda la prueba."

En la valoración de la prueba se ha adoptado en el proceso penal dominicano, por tanto, el criterio de la sana crítica, ya que el Juez o tribunal valora cada uno de los elementos de prueba, conforme a las reglas de la lógica, es decir, conforme las formas correctas del razonamiento hacia la consecución de la verdad; los conocimientos científicos, que es un conocimiento cierto y evidente logrado por la observación, reflexión y demostración de la realidad y las máximas de la experiencia que han sido definidas por Stein como "definiciones o juicios hipotéticos de contenido general, independiente del acto concreto a decidir en el proceso y de sus circunstancias singulares, adquiridas mediante la experiencia, pero autónomas respecto de los casos singulares de cuya observación se infieren y fuera de los cuales presenta valor para otros casos." 33

El Tribunal Supremo Español ha precisado "Ias máximas de la experiencia" como: "juicios hipotéticos obtenidos de hechos o circunstancias concluyentes, determinantes de conclusiones razonables en el orden normal de la convivencia, que el juez, sin excederse o sobrepasar el principio de aportación de hechos por las partes, puede utilizar..."34

En el estadio actual del desarrollo de la teoría y praxis de la prueba, denominada "ciencia de la criminalística", "ciencia de las pruebas" o "policía científica", se ha incorporado al patrimonio probatorio todo lo que es fruto de la ciencia, del análisis de indicio, trabajos de laboratorio, balística, estudio de huellas dactilares, de ADN, de medicina forense, de la tecnología digital, de la informática, telecomunicaciones, etcétera, por lo que la condena o absolución dependerá de lo que se haya o no probado en el juicio oral, público y contradictorio.

El derecho probatorio conforme con el nuevo Código Procesal Penal se fundamenta en primer lugar en el principio de legalidad, como ya se ha expresado, contenido en el Art. 26, principio que se define, en esencia, por su modo de obtención e incorporación al proceso conforme al principio de licitud, lo que significa que la recolección de la prueba sólo puede hacerse, para que tenga validez y pueda fundamentar la acusación y ser fundamento de la decisión judicial, en el respeto estricto a los derechos y garantías constitucionales o fundadas en el bloque de constitucionalidad, o sea, los instrumentos internacionales sobre derechos humanos, y es pedagógico reiterar entre otros: Declaración Universal de los Derechos Humanos del 1948; Declaración Americana de los Derechos Humanos del 1948; Pacto Internacional de Derechos Civiles y Políticos del 16 de diciembre de 1966, aprobado por el Congreso Nacional, mediante Resolución No. 684 de fecha 27 de octubre de 1977; y la Convención Americana de Derechos Humanos, del 22 de noviembre de 1969, aprobada por el Congreso Nacional mediante Resolución No.739, del 25 de diciembre de 1977, entre otros, en lo referente a las garantías judiciales y a los principios de igualdad, libertad y equidad. 
Otro principio fundamental es el de libertad de la prueba, lo que abre la posibilidad de admitirse todo medio de prueba que se adapte al principio de legalidad, como ya también se ha examinado.

La admisibilidad de la prueba está sujeta, en consecuencia, al principio de la pertinencia, llamada también relevancia, que se produce cuando el hecho por probar está en relación con el objeto del litigio o la materia del proceso o del incidente según el caso,35 o sea, "su referencia directa o inmediata con el objeto del hecho investigado". Solo los hechos que constituyen el fundamento de la pretensión o excepción deben ser probados y forman el tema u objeto de prueba, que se define como: hechos sobre los cuales habrá de decidirse, mediante los instrumentos y actividades, los medios de prueba, para fijar los hechos controvertidos.

Otro criterio de admisión de la prueba es su utilidad para descubrir la verdad. Para la admisión concreta de cada medio de prueba es indispensable que se cumplan los principios de conducencia, o sea que esté legalmente admitida la utilidad del medio, pertinencia del hecho que se va a probar, ausencia de prohibición legal de investigar el hecho e igualmente los requisitos extrínsecos de oportunidad procesal, legitimación de quien la pide o presenta y competencia del funcionario que debe admitirla u ordenarla.

Asimismo, la admisión de la prueba exige que los medios no sean "manifiestamente sobreabundantes"; 36 y pueda prescindirse de los medios de prueba cuando se trate de acreditar hechos notorios.

Además, en la valoración de la prueba impera el principio de la unidad de la prueba37, en razón de que los medios de pruebas aportados al proceso pueden ser múltiples cuando concurren, por ejemplo, el testimonio, el peritaje, la confesión, los indicios, entre otros. Todos ellos forman una unidad, un conjunto probatorio y como tal deben ser examinados y apreciados por el Juez, confrontando los diversos medios de prueba, puntualizando su concordancia o discordancia, y concluyendo el Juez conforme al convencimiento que de ellos globalmente se forme. 38

Asimismo, se convierte en un principio cardinal el de la comunidad de la prueba,39 lo que significa que esta no pertenece a quien la aporte sino, por el contrario, los medios de prueba aportados se hacen común a todas las partes y desde el momento que ellas produzcan la convicción o certeza del Juez, la función de éste se reduce a aplicar la norma reguladora de la situación de hecho controvertida, con independencia de quien ha aportado la prueba.

Aunque cada parte presente defienda sus medios de prueba, conforme a sus intereses, existe una unidad de fin y de función de esa prueba: obtener la convicción o certeza del Juez, y suministrarle "los medios a fallar conforme a la justicia" (Mittermair). 
La valoración de la prueba, conforme al Art. 172 del Código Procesal Penal, conlleva justificar las razones por las cuales se le da valor de verdad o se descartan los medios de prueba, con base a la apreciación conjunta y armónica de toda la prueba.

El Juez debe evitar la ignorancia, la pereza intelectual, debe dejarse asesorar por la jurisprudencia y la doctrina y en ocasiones, por expertos. Evitar, asimismo, dejarse llevar por simpatías y antipatías. El principio esencial es la imparcialidad del juez, que no debe limitarse a la primera impresión que dejan los medios de prueba 0 descuidar un examen de conjunto y el omitir una adecuada clasificación de los mismos.

Siguiendo la concepción de Hernando Devis Echandía, en el examen de la prueba es donde radica principalmente el concepto de justicia o injusticia que deja la sentencia en el lector imparcial. 40

La valoración de la prueba es la expresión de la certeza dejada en la conciencia del juez la argumentación que se infiere de los medios de pruebas aportados y admitidos por él, lo que se canaliza a través de mecanismos intelectuales que van desde el correcto razonamiento, o sea, su conformidad con las leyes de la lógica, teniendo preeminencia los razonamientos inductivos, deductivos, abductivos, hasta culminar en la subsunción de los hechos fijados en la norma general que se individualiza; en conjunción con los principios científicos y las máximas de la experiencia para que la valoración sea objetiva, sin arbitrariedad.

Para robustecer las ideas previamente desarrolladas expondremos la doctrina sustentada por el Prof. Dr. Miguel Langón Cuñarro sobre la actividad probatoria y la valoración de la prueba:

"Prueba es al mismo tiempo el medio empleado para la averiguación de la verdad y el resultado de la actuación jurisdiccional en el caso concreto objeto de análisis.

(1) Por un lado es la actividad que tiende a obtener la verdad material de lo ocurrido, ... y se ocupa por lo tanto de acreditar más allá de toda duda que:

(a) existe el hecho incriminado como tal;

(b) se ha comprobado la participación del involucrado;

(c) su grado de responsabilidad (su culpabilidad), y

(d) su personalidad, sus motivaciones, la razón de su actuar.

(2) Por otro, prueba son los "instrumentos" utilizados con tal fin.

"Para llegar a determinar la culpabilidad a través del proceso, dentro de las posibilidades humanas, con la prueba de cargo acumulada, se necesita alcanzar lo que llamamos la "verdad procesal", un hecho más allá de toda duda razonable". 
"Del mismo modo la prueba debe ser asegurada, a través de incautaciones de bienes u objetos relevantes para el caso, inspección de lugares o personas, incluida la prisión preventiva como medida de naturaleza prevalentemente cautelar, para asegurar la presencia del interfecto en el juicio, así como evitar que destruya la prueba de cargo, amedrente a los testigos, o se de a la fuga".

"Y también debe ocuparse de establecer el grado de veracidad, la calidad de los deponentes, sean testigos o intérpretes o peritos dentro de sus respectivas especialidades y campos de actuación".

"El principio que adquiere relevancia en la actualidad, en este punto, es el de la libre valoración judicial, o de la libre convicción que supone la comprensión del verdadero alcance y valor de la actividad jurisdiccional, el reconocimiento de sus poderes discrecionales, implícitos en el ejercicio de su función., y de la forma en que los hombres pueden llegar a adquirir un conocimiento adecuado y firme sobre cosas que no han presenciado con sus ojos por lo que deben pasar por las representaciones de los demás hasta formarse un juicio de culpabilidad o no respecto de un individuo concreto en una situación específica de vida humana".

"Actúa aquí por supuesto el principio del in dubbio pro reo, que es parte de uno más general que enunciamos diciendo, en caso de duda debe primar la libertad, precisamente porque la culpabilidad debe determinarse a través del proceso, y si no se conmueve el estado de inocencia en que se halla el imputado, más allá de toda duda razonable, deberá decretarse su absolución".

"Se supone que es a través de esa "sana crítica" que el juez debe llegar a la convicción moral respecto de la realidad que tiene entre sus manos para juzgar. La intención criminal, el dolo, sigue siendo un aspecto exquisitamente individual, de la conciencia de cada cual, que no puede conocerse de otro modo que a través de la explicitación del mismo al exterior, no tanto por las declaraciones del involucrado, sino también y sobre todo por las trazas que deja en los hechos objetivos realizados".

"Esto es tan así que incluso la propia confesión de intencionalidad, que aparentemente sería la única vía de conocer el fondo del alma humana, debe pasar por el tamiz de la crítica, ya que en no pocas ocasiones se han confesado, por multitud de razones, delitos que no se han cometido, o intencionalidades que jamás pasaron por la cabeza del autor".

"Así por ejemplo se puede confesar un delito que no se cometió o una intención que no se tuvo por haber sido torturado, para salvar a otro (por ejemplo a un hijo o a un hermano), o por simple debilidad mental o por afán de protagonismo y aún de figurar en las primeras páginas de los diarios como autor de un delito que no se cometió". 
"La convicción se debe basar en la prueba que se haya acumulado, se deben fundar y articular los argumentos y deducciones que la misma produjo, de forma tal que el juez pueda dejar de lado la presunción de inocencia, para afirmar en cambio, una sospecha de culpabilidad en el procesamiento, o una convicción de ello en el momento de la sentencia de condena".

"El juzgador, al resolver sobre una situación de vida humana concreta objeto de análisis no está sometido a un criterio de prueba tasada, sino que debe dar su veredicto según un juicio que se supone paradigmático del hombre medio, justo, experimentado, conocedor del corazón de los hombres, bueno, racional y razonable, que en base a los elementos obtenidos y al conjunto de la situación de que se trate, llega natural y razonablemente a una conclusión de culpabilidad que fluye como consecuencia no forzada de la prueba acumulada".41

\section{Actividad probatoria en el lavado de activos}

Partiremos de la tipificación del crimen de lavado de activos conforme con la Ley 72-02 que lo regula: El Art. 3 de esta Ley lo tipifica, o sea, describe la acción u omisión típica, antijurídica y culpable, en el ámbito del lavado de activos como:

"..., incurre en lavado de activos la persona que, a sabiendas de que los bienes, fondos e instrumentos son el producto de una infracción grave:

(a) Convierta, transfiera, transporte, adquiera, posea, tenga, utilice o administre dichos bienes;

(b) Oculte, encubra o impida la determinación real, la naturaleza, el origen, la ubicación, el destino, el movimiento o la propiedad de dichos bienes o de derechos relativos a tales bienes;

(c) Se asocie, otorgue asistencia, incite, facilite, asesore en la comisión de alguna de las infracciones tipificadas en este artículo, así como a eludir las consecuencias jurídicas de sus acciones."

La actividad probatoria en el lavado de activos es compleja por las razones de:

(1) El tipo penal de lavado de activos es considerado en la Ley No.72-02 como hechos autónomos, 42 lo que implica que su investigación, enjuiciamiento y fallo se hace independiente de la infracción de que proceda (delito base) y de la jurisdicción territorial en que han sido cometidos.

El crimen de lavado de activos, aunque es autónomo con respecto al delito base, o sea, a la infracción grave de la cual procede, no puede desligarse en razón de que el crimen de lavado lo que lo tipifica, la nota diferencial, es que los bienes que se convierten, transfieren, transporten, adquieran, posean, detenten, utilicen o administren sean el producto de una infracción grave, por lo que existe entre ambas infracciones una vinculación necesaria, ya que el delito precedente le aporta la esencia al crimen de lavado. 
El mismo razonamiento se aplica a la descripción del crimen de lavado en el aspecto de que se oculte, encubra o impida la determinación real, la naturaleza, el origen, la ubicación, el destino, el movimiento o la propiedad de los bienes o derechos relativos a tales bienes, fruto de una infracción grave. En este aspecto, se asimila el delito de lavado de activos al de encubrimiento.

Y siguiendo el análisis de la tipificación del delito de lavado de activo, a los fines de la actividad probatoria, en la letra c) del artículo 3, arriba transcrito, se tipifica, además, como tal la asociación para : otorgar asistencia, incitar, facilitar y asesorar para la comisión de las infracciones tipificados como delito de lavado de activos, asimilándose, además, la acción de eludir las consecuencias jurídicas de sus acciones, lo que es equivalente a la obstrucción de la justicia, y conforme a la sanción aplicable, que es la pena inmediatamente inferior a la aplicable al autor principal, o sea, a los descritos en las letras a) y b) según el Art. 19 en su párrafo, se ha tipificado la complicidad.

De conformidad con esa tipificación del lavado de activos, el autor del delito previo puede asimismo ser considerado como autor de lavado de activos y ser pasible de ser penado en concurso con el delito precedente.

Concordamos con la doctrina sustentada por el Dr. Ricardo Pinto y Dra. Ophelie Chevalier, en El Delito de Lavado de Activos como Delito Autónomo, según la cual, "... por consideraciones de política criminal es aconsejable admitir la sanción del autor del hecho previo como posterior lavador. Así, vimos que existen organizaciones criminales que, entre otros delitos, se dedican a lavar capitales y afectan no sólo la administración de justicia, sino esencialmente el orden económico de los países y la comunidad internacional. Por lo tanto, para un control efectivo del fenómeno el blanqueo de capitales deber ser comprendido no sólo como una forma de encubrimiento sino como un delito independiente (autónomo) contra el orden socioeconómico". 43

Esta es la concepción jurídica adoptada en la Ley 72-02 en su articulado No. 5, que prevé explícitamente:

"Las infracciones previstas en esta ley, así como los casos de incremento patrimonial derivados de actividad delictiva, serán investigados, enjuiciados, fallados como hechos autónomos de la infracción de que proceda e independientemente de que haya sido cometidos en otra jurisdicción territorial".

El lavado de activos cae en la categoría de "asuntos complejos", según lo define Art.369 del Código Procesal Penal a causa de la pluralidad de hechos, del elevado número de imputados que pueden ser involucrados o de victimas, pero sobre todo por tratarse de crimen organizado.

Siendo autónomo el crimen de lavado de activos, conforme con el Art. 5 citado, se precisa establecer los elementos constitutivos de este tipo penal, así como del delito o delitos graves que lo preceden: el elemento 
material o fase objetiva, dentro de la cual se debe establecer lo siguiente:

i. La acción u omisión típica, aquella que se adecua al tipo penal, o sea, al lavado de activo.

ii. La antijuridicidad, es decir, acción u omisión contraria a la voluntad del derecho

iii. La culpabilidad, en el sentido de conocimiento del hecho que integra el tipo, acompañado por la voluntad de realizarlo, el dolo directo o "a sabiendas".44

(3) El primer elemento que debe acreditarse es el denominado material que comprende: la acción u omisión que lesiona el bien jurídicamente protegido o lo pone en peligro; así como el resultado de la misma, conforme al supuesto ilícito establecido en la norma, también designado como la "faz objetiva", con sus componentes de sujeto o sujetos activos, ya sean autores o cómplices; el objeto material de la acción, es decir, cosa o persona sobre la cual la acción u omisión recae, con todas sus circunstancias de lugar. En la legislación dominicana sobre lavado de activos, es independiente de que se haya cometido en otra jurisdicción territorial.

Deben acreditarse, asimismo, las demás circunstancias, que puedan agravar la acción u omisión, que en el caso de lavado de activos están previstas en el artículo 21 de la citada Ley 72-02 sobre lavado de activos como son:

(a) La participación de grupos criminales organizados;

(b) El hecho de haber cometido el delito en asociación de dos o más personas;

(c) Cuando el agente autor del delito hubiese ingresado al territorio nacional con artificios o engaños o sin autorización legal, sin perjuicio del conjunto de delitos que puedan presentarse;

(d) Cuando el que comete el delito ostente un cargo público o fuese funcionario o servidor público encargado de la prevención o investigación de cualquier delito, o fuviese el deber de aplicar penas o vigilar su ejecución;

(e) Las reincidencias;

(†) El empleo de menores para facilitar la ejecución del delito y el uso de instituciones educativas a los mismos fines.

En la faz objetiva o elemento material en la configuración del delito debe quedar establecido el resultado de la acción u omisión, en el cual se concretiza la lesión o sea el daño- la consumación del delito- o puesta en peligro del bien jurídico tutelado, como en el caso de la tentativa cuando es castigada como la infracción misma45, o sea el delito de peligro concreto, para lo cual están disponibles como instrumentos probáticas todos los medios de pruebas legales, sin limitación. 
En la faz subjetiva o elemento intencional, la actividad probatoria se dirige a la vinculación entre el supuesto sujeto o sujetos activos o cómplices y el daño o lesión o la puesta en peligro del bien jurídicamente protegido.

En sentido genérico la conducta dolosa se caracteriza por el conocimiento del hecho que integra el tipo, con la voluntad del sujeto de realizarlo o aceptar el resultado que sobrevenga a consecuencia de su actividad voluntaria.

En el dolo concurren el elemento intelectual, o conocimiento del hecho antijurídico; y el elemento volitivo, o sea, la voluntad de realizar el hecho típico o de aceptar los resultados de la actuación contraria a la voluntad de la ley.

En el campo del delito de lavado de activo la existencia del elemento intencional o faz subjetiva queda caracterizada en el hecho de realizar la actividad "a sabiendas", lo que se establece por todos los medios de pruebas idóneos o sea legítimos, y aún se podría inferir de las circunstancias objetivas del caso, de conformidad con el Art. 4 de la Ley 72-02, o sea a través de la prueba indiciaria o circunstancial, de la cual nos ocuparemos más adelante.

Con relación al dolo como elemento subjetivo, desde el aspecto del objeto de la prueba, a que se refiere el citado Art. 3 no es sólo el denominado "dolo directo" que es aquel en que el objetivo perseguido por el agente es la realización del hecho típico, o sea "a sabiendas", sino que analizada esta norma en combinación con el Art. 4 queda incluido el dolo eventual, que algunos autores llaman "dolo indirecto" o de "segundo grado", que consiste en imputar un resultado no querido, pero previsto y asumido, lo que es coherente con el Art. 4 de la Ley 72-02 que establece:

El conocimiento, la intención o la finalidad requeridos como elementos de cualquiera de las infracciones previstas en esta sección, así como en los casos de incremento patrimonial derivado de actividad delictiva consignada en esta ley, podría inferirse de las circunstancias objetivas del caso.

Con esta interpretación no se viola el principio de presunción de inocencia, sino que es una herramienta de interpretación y valoración de la prueba.

Es ilustrativo citar la doctrina de Langon Cuñarro sobre la prueba del elemento intencional:

"Por el contrario, la experiencia cotidiana muestra que la negativa más cerrada de intencionalidad criminal decae ante la contundencia de los hechos y la intencionalidad puede quedar objetivada en la forma de comisión" .46 
"De allí que la expresión de la Convención de Viena o del Reglamento Modelo sobre que la intención puede deducirse de las circunstancias objetivas del caso, no hace otra cosa que explicitar, en este caso concreto de las drogas, un principio general de interpretación legal". 47

"El proceso de convencimiento del juez que lo lleve a la íntima convicción de culpabilidad, única que lo puede habilitar a condenar, debe ser un proceso fundamentado y racional, del cual deberá dejarse constancia en la sentencia de condena, de forma, entre otras cosas, de habilitar una revisión posterior, por un Tribunal de superior instancia, que pueda reconstruir el pensamiento que llevó al juez unipersonal a tomar tal decisión".48

En este aspecto de la prueba, puede concluirse que la faz subjetiva, el elemento intencional, tiene como centro establecer la culpabilidad del agente o agentes del tipo penal, conceptualizándose ésta como "la responsabilidad del hecho típico o antijurídico fundado en que su autor lo ejecutó no obstante que en la situación concreta podía someterse a los mandatos y prohibiciones del derecho". 49

Con el establecimiento de la culpabilidad, en el lavado de activos, ya sea por la verificación del dolo directo 0 ya por el indirecto, o sea, la actuación del agente "a sabiendas", queda configurado el elemento intencional del tipo criminal y se satisface el presupuesto de la norma, para la imposición de la pena, en cumplimiento al principio de legalidad de que "no hay pena sin culpabilidad". 50

Comprobada la culpabilidad se individualiza la antijuridicidad del hecho imputado, lo que lo tipifica.

En la culpabilidad hay que establecer por los medios de pruebas correspondientes, la imputabilidad, lo que se entiende por el hecho de que el sujeto es capaz de conocer lo ilícito de su conducta y de actuar conforme a ese conocimiento. En consecuencia, la imputabilidad se basa sobre un cierto estado de normalidad y suficiencia de las facultades intelectuales y volitivas, por lo que si esas facultades se encuentran alteradas en forma apreciable que determinen que el sujeto o los sujetos no han alcanzado el desarrollo normalmente aceptado, son excluidos del proceso penal general por inimputables, los que están expresamente determinados por la ley, caso de los menores de edad que caen bajo una jurisdicción especializada, como los de niños, niñas y adolescentes y otros inimputables como los regulados en los artículos 374 al 376 del Código Procesal Penal.

Tanto en la faz objetiva como subjetiva se desenvuelven dentro de lo denominado por Rafael De Asis Roig, en su obra sobre Jueces y Normas, ${ }^{51}$ como juicio de hecho, en que se produce una interacción entre los hechos imputados, las pruebas de cargo y descargo aportadas al proceso, y las argumentaciones de las partes en apoyo de las respectivas tesis de acusación y de defensa, que luego de la valoración de las pruebas en el ámbito penal, de conformidad con los principios de libertad de pruebas y de legalidad, los hechos quedan probados, fijados; habiendo quedado depurado en el silogismo jurídico la premisa menor, de lo fáctico, y 
quedando expedito lo denominado el juicio de derecho, según el cual, acreditados los hechos conforme con la tesis de la acusación se produce la subsunción, o sea, el encuadramiento de los hechos fijados con el texto legal que configura la premisa mayor constituida por la norma violada, o sea, ha quedado establecido que el disvalor de que es portador un hecho ilícito, típico, que contradice las normas del deber contenidas en el ordenamiento jurídico, se ha consumado y procede la calificación de los hechos según el texto legal que lo tipifica; y concretizada la culpabilidad del agente o agentes, se hacen pasible de la sanción correspondiente, en virtud del principio de legalidad que estipula que no hay pena sine lege previa. 52

\subsection{La prueba documental}

Se define doctrinalmente al documento como un medio de prueba indirecto, real, objetivo, histórico y representativo, en ocasiones constitutivo o declarativo de derechos, otras veces representativo como las fotografías, los cuadros, los planos, que puede contener una simple declaración de ciencia o un acto de voluntad con efectos jurídicos.

Es, en principio, un acto extra procesal, en sentido estricto, que lo diferencia de los actos y resoluciones resultantes de diligencias procesales que contienen decisiones del juez o actuaciones de las partes. En este caso no es un medio de prueba, salvo que la ley expresamente lo determine cuando se obtengan los actos procesales para la comprobación inmediata y medios auxiliares de prueba, conforme al Título II, del Libro IV, como en los casos siguientes:

(a) Inspección del lugar del hecho, en que los funcionarios del Ministerio Público o de la policía deben custodiar el lugar del hecho y comprobar mediante la inspección del lugar y de las cosas, los rastros y otros efectos materiales que sean el resultado del hecho punible y el funcionario a cargo de la inspección levanta acta en la cual describe detalladamente el estado de los lugares y de las cosas, recoge y conserva los elementos probatorios útiles dejando constancia de ello en el acta. Ésta debe ser firmada por el funcionario o agente responsable y de ser posible por uno o más testigos, y bajo esas formalidades puede ser incorporada al juicio por su lectura, sin perjuicio de que el funcionario y el testigo instrumental puedan ser citados para prestar su testimonio, conforme con el Art. 173 del indicado Código Procesal Penal.

(b) En el caso de registros de personas: En los que antes de procederse al registro personal el funcionario actuante debe advertir a la persona sobre la sospecha de que entre sus ropas o pertenencias ocultan un objeto relacionado con el hecho punible invitándola a exhibirlo y estos registros de personas se practican separadamente respetando el pudor y dignidad de las personas y en su caso por una de su mismo sexo. Dicho registro se hace constar en acta levantada al efecto que debe incluir el cumplimiento de la advertencia previa sobre el objeto buscado, la firma del registrado y si rehúsa a 
hacerlo se hace mención de esta circunstancia, y en estas condiciones el acta puede ser incorporada al juicio por su lectura. Estas mismas normas se aplican al registro de vehículo.

(c) En este mismo sentido se regula en los artículos 179 al 184, el registro de moradas y lugares privados y registro de locales públicos. Cumplidas con las formalidades, como son el horario (Art. 179), a solicitud del Ministerio Público, con la orden de allanamiento del juez competente, demás requisitos indicados en el Art. 182, y el procedimiento establecido en el Art.183, en lo relativo al allanamiento de moradas y lugares privados, y con respecto al registro en los locales públicos, como son dependencias estatales, locales comerciales y los dedicados al esparcimiento público, en presencia del responsable o encargado del lugar, y a falta de éste de cualquier dependiente, de un vecino 0 persona mayor de edad, se levanta el acta que puede ser incorporada a juicio por su lectura, sin perjuicio de que el funcionario y testigos puedan ser citados a juicio para prestar su testimonio.

Esas actas, a consecuencia de los allanamientos y registros precedentemente indicados, tienen la categoría de documentos, que se incorporan al juicio oral, público y contradictorio mediante su lectura, como excepción al principio de oralidad.

En la legislación procesal dominicana no se define el concepto jurídico de documento. En el nuevo Código Procesal Penal se refiere a unos tipos particulares de documentos, al regular en el Art. 140 a las grabaciones, en el sentido siguiente:

"El registro de imágenes o sonidos se puede emplear para documentar total o parcialmente actos de prueba 0 audiencias. Queda prohibida, sin embargo, toda forma de edición de las imágenes o sonidos registrados.

La autenticidad e inalterabilidad de estos registros se asegura con los medios técnicos idóneos. Los originales se deben preservar en condiciones que garanticen su inviolabilidad hasta el juicio, sin perjuicio de la obtención de copias para utilizarse a otros fines del proceso.

Estos registros pueden ser incorporados al debate en los mismos casos previstos para la lectura de los documentos escritos.

En lo aplicable, rigen las formalidades previstas en el artículo anterior

El documento, se establece como medios de prueba cuando específicamente en el Art. 305 relativo a "Fijación de audiencia y soluciones de los incidentes", se expresa que:

"En el mismo plazo de cinco días de la convocatoria, las partes comunican al secretario el orden en que 
pretenden presentar la prueba. El secretario del tribunal notifica de inmediato a las partes, cita a los testigos y peritos, solicita los objetos, documentos y demás elementos de prueba y dispone cualquier otra medida necesaria para la organización y desarrollo del juicio".

En ese mismo sentido el Art. 312 al hablar sobre las "Excepciones a la oralidad", expresa: "Pueden ser incorporadas al juicio por medio de la lectura: 1. Los informes, las pruebas documentales y las actas que este código expresamente prevé". Asimismo el Art. 329 referente a Otros Medios de Prueba dice: "Los documentos y elementos de pruebas son leídos o exhibidos en audiencia, según corresponda, con indicación de su origen". Se explicita, además, que: "Ias grabaciones y los elementos de prueba audiovisuales son reproducidos. Las partes y el tribunal pueden acordar, excepcionalmente y por unanimidad la lectura, exhibición o reproducción de esos medios de prueba, cuando esa lectura o reproducción baste a los fines del debate en el juicio."

Por esas disposiciones y por el principio de la libertad de prueba, consagrado en el Art. 170 que establece que Ios hechos punibles y circunstancias pueden ser acreditados mediante cualquier elemento de prueba permitido, salvo prohibición expresa, se permite el acceso del documento como medio de prueba idóneo.

Existen documentos necesarios para la existencia o validez de los actos jurídicos, lo que se entiende como requisitos ab solemnitatem o ad substantiam, cuya naturaleza es mixta, ya que son al mismo tiempo instrumentos de prueba cuya función se cumple tanto dentro como fuera del proceso y solemnidad substancial o material del acto jurídico para su validez se requiere el cumplimiento de formalidades substanciales, como ejemplo los testamentos, los actos constitutivos de sociedades comerciales, las asociaciones sin fines de lucro, entre otros. La mayoría de los documentos tienen un valor jurídico ad probationem. ${ }^{53}$

Los documentos pueden ser apreciados no solo como "medio de prueba", sino como objetos materiales, que presentan en sí, recogida y fijada, la manifestación de un pensamiento, de una voluntad o la enunciación de un hecho propio o la narración de un acontecimiento, llevado a cabo por una persona o personas conocidas o conocibles, y se excluyen de esta clasificación como objeto de prueba, los papeles que durante el procedimiento se certifican como declaraciones o acontecimientos procesales o en que simplemente se integran declaraciones, ya que estos constituyen documentos procesales.

En cuanto a su contenido, los documentos pueden ser cualquier cosa, con la condición de que reflejen una ciencia o conocimiento, una idea, una declaración de voluntad, una manifestación de un estado psíquico de su autor, o referirse a cosas y acontecimientos.

En cuanto a la forma, es excluyente toda limitación a priori del contenido material; puede ser recogido, fijado y expresado por todos los signos: escritura, cifras, dibujos, signos telegráficos y electrónicos, taquigráficos, 
grabaciones: en madera, cobre o bronce, como por ejemplo las monedas, medallas, inscripciones sobre piedras, como serían las lápidas, soportes digitales, las notas musicales, la pintura, la escultura, superficie de muros, etcétera.

El documento en el proceso penal, tiene su propia dinámica en relación con la prueba ya sea como objeto de la prueba ya como medio de prueba.

El documento es objeto de prueba porque siempre es algo material, que se introduce al proceso para su observación, verificación, y para ser examinado tal como es. ${ }^{54}$

En el contexto del Código Procesal Penal, en el juicio oral, público y contradictorio, los documentos como elementos de prueba son leídos y exhibidos en la audiencia, con indicación de su origen; las grabaciones y los elementos de prueba son reproducidos. ${ }^{55}$

Para que los hechos, en su sentido más amplio, y los documentos, se conviertan en objeto de prueba, es necesario que participen de la vida del proceso, que sean allegados 0 introducidos por medios legales adecuados.

La prueba documental por ser una prueba preconstituida juega un papel fundamental para establecer los elementos constitutivos que configuren el tipo penal del lavado de activos: determinar que los bienes, fondos e instrumentos son el producto de una infracción grave, y cuyo agente ha actuado a sabiendas, lo que implica una multiplicidad de operaciones como convertir, transferir, transportar, poseer, tener y utilizar, con las características de ocultar, encubrir o impedir la determinación real, la naturaleza, el origen, la ubicación, destinos, movimiento o la propiedad de dichos bienes, o derechos relativos a los mismos.

\section{Requisito para la validez del documento como medio de prueba, conforme a los siguientes criterios:}

(I) Cuando se trate de instrumentos públicos o privados que se hayan cumplido las formalidades exigidas por la ley para su formación bajo sanción de nulidad:

(a) Cuando se trata de documentos públicos, o sea el denominado en nuestra terminología jurídica acto auténtico o solemne que es aquel que ha sido otorgado por ante oficiales públicos, como los Notarios, Oficiales del Estado Civil y quienes tienen derecho de actuar en el lugar donde se otorgó el acto y con las solemnidades establecidas por la ley. El mismo hace plena fe respecto a la convención que contiene entre las partes contratantes y sus herederos o causahabientes, es decir, hasta inscripción en falsedad, ejemplos las escrituras públicas otorgadas ante notarios, las actas del estado civil, sentencias publicadas, etcétera. 
Se incluyen los actos solemnes que son una variedad de los públicos, para cuya validez la ley requiere el cumplimiento de ciertas formalidades, como en los casos de los testamentos, las donaciones entre vivos, y los contratos de matrimonios, entre otros.

(b) Documento privado o acto bajo firma privada, que es el reconocido por aquel a quien se le opone o tenido legalmente por reconocido, teniendo entre los que lo han suscrito, y sus herederos o causahabientes, la misma fe que el acto auténtico56 y hacen fe, con respecto a terceros, hasta prueba en contrario. Tiene un valor jurídico equivalente al acto bajo firma privada, el acto auténtico otorgado por un oficial público incompetente o incapaz para instrumentarle o con defecto de forma, si está firmado por las partes. 57

(c) Entre la prueba documental está el contradocumento o contraescrito, acto secreto destinado a modificar o suprimir los efectos de otro celebrado ostensiblemente y al mismo tiempo entre las mismas personas, y que hace de este último, por esa razón, un acto simulado en todo o en parte y, conforme al artículo 1321 del Código Civil, sólo surte efecto entre las partes contratantes, por lo que no es oponible con respecto a terceros, como lo sería el Estado, en caso de acusación por acción pública como lo es en caso del lavado de activos.

(II) Si el acto o documento es declarativo o constitutivo de derecho: que no se haya elaborado en violación al principio de la libertad jurídica del autor, o sea, contra la voluntad de quien otorga el negocio jurídico (negotium), lo que implica una violación a derechos y garantías del imputado, a su libertad o libre albedrío58, ya sea que el consentimiento sea sorprendido por dolo, arrancado por violencia o por error sustancial. 59

(III) Si se trata de copias que hayan cumplido los requisitos exigidos por la ley para su expedición.

(IV) Que se haya incorporado al proceso de un modo legítimo o sea que la aproximación del documento al proceso sea por un medio lícito60, por ejemplo que no haya sido adquirido mediante la violación al derecho de propiedad que sobre el mismo tenga una de las partes o un tercero; ni que se empleasen la violencia, coacción o dolo para obtener el documento que está legítimamente en poder de otra persona, entre otros.

(V) Que se haya aportado y admitido al proceso el documento conforme al debido proceso de ley, o sea en cumplimiento, entre otros, de los principios de oralidad, publicidad, igualdad, contradicción e inmediación, como principios estructurales del debido proceso de ley. Se entiende la oralidad como el hecho de ser sometida la prueba documental al juicio oral, por quienes intervienen en el debate, conforme al artículo 311 del Código Procesal Penal, salvo la excepción establecida en el Art. 312, según la cual: 
"Pueden ser incorporados al juicio por medio de la lectura: 1) Los informes, las pruebas documentales y las actas que este Código expresamente prevé; 2) Las actas de los anticipos de pruebas, sin perjuicio de que las partes soliciten al tribunal la comparecencia personal del testigo, cuando sea posible; 3) Los informes de peritos, sin perjuicios de que los peritos deban concurrir para explicar las operaciones técnicas realizadas y las conclusiones a las que han llegado; y siendo la excepción al principio de oralidad de orden público, cualquier elemento de prueba que se pretenda incorporar por medio de lectura a juicio fuera de los casos establecidos taxativamente por ley no tiene valor alguno".

El principio de contradicción implica que la parte contra quien se opone el medio de prueba debe gozar de oportunidad procesal para conocerla y discutirla lo que incluye el ejercicio del derecho de defensa, es decir, que debe llevarse a la causa con conocimiento y audiencia de todas las partes, lo que está garantizado en el Art. 8, inciso 2, letra j) de la Constitución de la República Dominicana.

El principio de igualdad ante la ley y de igualdad en el proceso o igualdad de armas, implica que la igualdad debe ser plena ante los tribunales y cortes de justicia, según la Resolución No. 1920 del 13 de noviembre del 2003; Art. 8.5 y 100 de la Constitución de la República Dominicana; Art. 1.1 Convención Interamericana de Derechos Humanos, y la Declaración Universal de los Derechos Humanos.

El principio de inmediación, según el cual la discusión de la prueba documental se realiza con la presencia ininterrumpida de los jueces y de las partes, en virtud del Art.307 del Código Procesal Penal, entre otros principios estructurales del debido proceso.

(VI) Los documentos como medios de prueba deben aportarse dentro de los plazos establecidos, y en el nuevo Código Procesal Penal, por las causales siguientes:

(a) Conforme con el Art. 293 del Código Procesal Penal, el Ministerio Público a quien le corresponde el ejercicio de la acción publica, una vez concluido el procedimiento preparatorio de la investigación, que está bajo su dirección directa y funcional, debe requerir por escrito la apertura a juicio, ante el Juez de la instrucción, mediante la acusación. Ésta debe estar fundamentada en los elementos de prueba que sirven de sustento a dicha acusación y remitir al Juez, por consiguiente, los documentos que producirá como medio de prueba para fundamentar la aludida acusación.61

(b) La acusación, para someter a juicio al imputado, debe ser presentada por el Ministerio Público, cuando esté fundamentada con los elementos de prueba que la justifican.62

(c) El mismo Art. 294 establece de manera explicita en su ordinal 5) lo siguiente: El ofrecimiento de la prueba que se pretende presentar en juicio incluye lista de testigos, peritos y todo otro elemento de prueba - como lo es la prueba documental- con la indicación de los hechos o circunstancias que se pretende probar y lo es en el nuevo Código Procesal Penal, a pena de inadmisibilidad. 
(d) En la audiencia preliminar ante el Juez de la instrucción al presentarse la acusación, el Secretario notifica a las partes y se le requiere al Ministerio Público, poner a disposición de las mismas, los elementos de prueba reunidos durante la investigación. Ellos pueden examinarlos en el plazo de cinco días, en cumplimiento al principio de contradicción.63

(e) El auto de apertura a juicio sólo se dicta por el Juez de la instrucción cuando existan los elementos de prueba suficientes para justificar la probabilidad de una condena, lo que implica que el o los documentos como medio de prueba deben ser aportados antes de la apertura del juicio. 64

\section{Eficacia de los medios de prueba}

No es suficiente aportar los medios de prueba sino que deben llenar unos requisitos para la eficacia probatoria del documento. Exponemos los más relevantes:

(a) Que esté establecida o presumida su autenticidad como asevera Hernando Devis Echandía.65 Este es un requisito indispensable tanto si se trata de un documento público como privado, como si es un documento no declarativo ni constitutivo de derechos como un plano, fotografía, un cuadro, una grabación magnética, electrónica, el disco duro de una computadora, dísete, CD-ROM, entre otros. El juez debe ponderar la autenticidad del documento para admitirlo y valorarlo como medio de prueba. Aquella puede resultar de una presunción legal como los instrumentos auténticos, mientras no se demuestre la falsedad material de la firma del oficial público que lo autoriza o la de su contenido. En el caso de documentos privados, mediante el reconocimiento de la parte a quien se opone, ellos no gozan de la misma presunción de autenticidad que los documentos públicos. Los documentos bajo firma privada no reconocida expresa o implícitamente carecen de autenticidad y de valor probatorio como medio de prueba, ni aún como simple indicio.

(b) Que cuando se trate de instrumentos otorgados en el exterior se cumplan las formalidades para su elaboración y autenticidad. Como documentos por excelencia nos referiremos a las sentencias dictadas por tribunales de otros Estados con los cuales se mantienen relaciones de cooperación internacional. En razón de que toda sentencia de un tribunal jurisdiccional es una expresión de la soberanía del Estado que la dicta, se requiere para su ejecución de la formalidad del exequátur u homologación por los tribunales nacionales y, de conformidad con el Art. 122 de la Ley 834 del 15 de julio de 1978, que modifica disposiciones del Código de Procedimiento Civil, en este caso constituye el derecho común, según el cual "Ias sentencias rendidas por los tribunales extranjeros y los actos recibidos por los oficiales extranjeros son ejecutorios en el territorio de la República, de la manera y en los casos previstos por la ley". ${ }^{66}$ Con relación al lavado de activos, la Ley No.72-02, sobre Lavado de Activos Provenientes del Tráfico llícito de Drogas y Sustancias Controladas y Otras Infracciones Graves, del 7 de junio del 2002, cuyo Art. 64 establece que 
"La sentencia dictada por un juez o tribunal competente de otro Estado, con relación a una infracción de lavado de activos que ordene el decomiso de bienes, productos o instrumentos situados en la República Dominicana, podrá ser homologada por el tribunal competente del país al tenor del principio de reciprocidad consignado en los acuerdos multilaterales y bilaterales de los que el país haya suscrito o adherido en la materia y ratificado por el Congreso Nacional".

En lo relativo a otros tipos de actos instrumentados por funcionarios extranjeros, como aquellos que produzcan hipotecas sobre bienes que radican en la República se requiere asimismo, para ser ejecutados, que un tribunal competente de la República los declare ejecutivos, conforme a los artículos 2123 y 2128 del Código Civil Dominicano.

La ejecutoriedad de actos extraprocesales rendidos en el extranjero a los fines de medidas cautelares o decomiso sobre bienes situados en el territorio nacional o a los fines de prueba informativa, deben estar debidamente autenticados y sometidos a los principios de reciprocidad conforme a los convenios multilaterales y bilaterales suscritos entre los Estados y con los principios de cooperación judicial internacional según se ha expuesto precedentemente.

(c) Que no haya prueba legalmente válida en contra de la sinceridad y veracidad de lo contenido en el documento, conforme con el principio de contradicción y la puesta en común entre las partes de todos los medios de prueba de igual o mejor calidad, de cuya confrontación resultará el mérito de cada uno de los elementos de prueba y de manera específica del documento admitido como instrumento de prueba, según los principios de la libertad en la valoración de la prueba, lo que es aplicable a los demás elementos de prueba como la testimonial, confesión o declaración del imputado.

(d) Que el contenido mismo del documento sea convincente, siguiendo el razonamiento de Hernado Devis Echandía. 67 En este aspecto ese requisito significa que el documento sirva para darle al Juez, por sí sólo o conjuntamente con otras pruebas, el convencimiento sobre los hechos investigados o que se pretende demostrar. En este punto hay que considerar la redacción, la claridad de las declaraciones y su alcance, según se trate de documentos públicos o privados, y si el Juez goza de libertad de valoración, según la naturaleza de la prueba.

(e) Que no se haya llevado al juicio con la reserva o secreto que la ley haya consagrado, como serían los casos de la correspondencia privada y del secreto profesional. En este aspecto en materia de lavado, y de conformidad con la Ley No.72-02 indicada, en el Art. 41 sobre los sujetos obligados quedan sometidos los profesionales liberales cuando actúen en el ejercicio de su profesión, como intermediarios financieros. Ellos no podrán invocar el secreto profesional para rechazar revelar la identidad de la tercera parte de la transacción (Art. 41.3). En igual sentido se rompe el secreto en los casos de reporte de transacciones en efectivo conforme al Art. 41.4 que ordena: "Comunicar, dentro de los primeros quince (15) días de cada mes, mediante formularios o a través de soporte magnético 
a la Unidad de Análisis Financiero, vía la Superintendencia de Bancos, para las instituciones que estén bajo la supervisión de esta entidad, todas las transacciones en efectivo realizadas en el mes anterior que superen la cantidad de diez mil dólares de los Estados Unidos de América (US\$10,000.00) u otra moneda extranjera o su equivalente en moneda nacional, calculado en base a la tasa oficial de cambio establecida por el Banco Central de la República. Las transacciones múltiples en efectivo realizadas en una o mas oficinas de la misma entidad, que en su conjunto superen la cantidad de diez mil dólares de los Estados Unidos de América (US\$10,000.00) u otra moneda extranjera o su equivalente en moneda nacional, serán agrupadas y consideradas como una transacción única si son realizadas en beneficio de una misma persona, física o moral, durante un día laborable. En tal caso, dichas transacciones deberán ser reportadas a la Unidad de Análisis Financiero".

(†) Que se haya hecho el registro público del documento que la ley exige, caso de los documentos bajo firma privada, que no tienen fecha cierta con respecto a terceros sino desde el día en que han sido registrados, desde la fecha de la muerte de cualquiera que los haya suscrito o desde el día en que su sustancia se ha hecho constar en actos autorizados por oficiales públicos, tales como los expedientes de colocación de sellos o de inventario.68

(g) Requisitos especiales de ciertos documentos privados, como los que contengan Convenciones sinalagmáticas, no son válidos sino cuando han sido hechos en tantos originales como partes hayan intervenido con interés jurídicos distintos ${ }^{69}$. En el caso del testamento ológrafo el mismo no será válido si no está escrito por entero, fechado y firmado de manos del testador, y no está sujeto a ninguna otra formalidad. 70

(h) Que el documento esté completo sin alteraciones, mutilaciones o tachadura que alteren su contenido y plena fe, según Mittermier "debe presentarse en toda su integridad, sin la menor señal de alteración o mutilación".

(i) Que el documento tenga la virtualidad de una prueba plena, en el sentido de dar prueba completa o perfecta sobre la certeza del hecho a probar.

\section{Prototipos de medios de prueba documental en proceso de lavado de activos}

Luego del sucinto análisis del concepto de documento, a título de ejemplo, revisemos a continuación una relación de cosas u objetos que pueden constituir documentos con fuerza probatoria en investigaciones o juicios al fondo por delitos de lavado de activos:

(a) Documentos de identificación: cédulas de identificación personal, registros civiles o eclesiásticos de nacimiento o del estado civil, tarjetas militares, pasaportes, visas o registros migratorios, licencias de conducir autos o naves aéreas o acuáticas, tarjetas de identificación de empleos particulares u 
oficiales, etc., con los cuales se puede demostrar parentesco o relación entre imputados, cómplices o sospechosos, o bien para la necesaria identificación plena de personas implicadas.

(b) Documentos de pago: cheques, letras de cambio, recibos de consignación de dinero, recibos de transacciones de dinero a través de cajeros automáticos, pagarés, tarjetas de crédito, tarjetas de débito, cheques viajeros, giros postales (Money Orders), dinero efectivo en moneda nacional o extranjera, recibos de depósito a término fijo, cupones o desprendibles de cheques, entren otros, que pueden ser útiles tanto para probar la capacidad patrimonial de las personas, como para establecer si hay o no relaciones entre ellas.

(c) Documentos de propiedad: certificados de títulos duplicados del dueño, del acreedor hipotecario, o de otros derechos registrables conforme a la Ley de Registro de Tierras, vigente; escrituras públicas o privadas de compraventa, facturas, recibos de abonos por pagos a crédito, hipotecas, licencias de importación o exportación, manifiestos de aduana, testamentos, sentencias de sucesión, y similares.

(d) Contratos: laborales, de arrendamiento de bienes muebles o inmuebles, de compraventa de bienes muebles o inmuebles, de constitución o reforma de sociedades, contratos de comodato, contratos de mutuo, contratos de préstamos, de depósitos, etcétera.

(e) Certificados diversos: de registro inmobiliario, automotor y de naves aéreas o acuáticas; de Cámaras de Comercio, de Oficinas de Impuestos locales o nacionales (declaraciones de renta o pagos de impuestos), académicos (expediciones de títulos o certificados de escolaridad), de membresía de clubes, etc., que pueden servir para complementar, corroborar o desvirtuar pruebas de propiedad e incluso de una condición especial de alguna de las personas imputadas o sospechosas de haber incurrido en alguna actividad ilícita.

(†) Soportes informáticos: discos duros de computadoras, discos blandos (diskettes), discos compactos, discos de compactación de información (Zip), discos ópticos, impresoras, agendas digitales y electrónicas de toda especie, teléfonos celulares, cassettes de audio y video, discos de DVD, cámaras digitales y dispositivos de memoria paralela, que son útiles para los fines del aseguramiento de las pruebas.

(g) Escritos o imágenes impresas: manuscritos, libros de contabilidad y de comercio en general, fotografías y álbumes fotográficos, agendas de papel, libros que contienen anotaciones manuscritas o dedicatorias, cuadros, recetas médicas, recibos de pagos de peajes, tarjetas de invitación o de presentación personal, tickets aéreos o de otra especie, cupones de pases para abordar vuelos, marcas de mercancía (con mayor razón si son las marcas que a veces les ponen los narcotraficantes a los envíos de drogas, aunque a veces lo hagan para distraer a las autoridades), poderes conferidos a abogados, copias de procesos judiciales. 
Amerita un estudio más detenido sobre los documentos que se describen a continuación, desde el punto de vista de su utilización como instrumentos probáticos partiendo de las consideraciones de Herman Rincón Cuéllar, en su exposición sobre "Práctica y Aseguramiento de las Pruebas en el Proceso Penal":

"Agendas electrónicas. Con la ayuda de un técnico en la materia pueden buscarse los archivos, en Ios cuales ordinariamente se guardan números telefónicos, direcciones de correo electrónico, números de escrituras públicas, de cuentas corrientes o de ahorros, de certificados de depósitos, etc., que en un momento determinado pueden ser utilizados para el descubrimiento de la verdad".

2. "Buscapersonas. Es importante tener en cuenta que el hallazgo de buscapersonas no solamente puede ser útil para leer los mensajes actuales o que se encuentren en la memoria, sino además para acudir ante la empresa prestadora del servicio con el fin de obtener la historia de esas comunicaciones o fundamentos para ordenar judicialmente la intervención de otras, la identificación del usuario o la persona que pague el servicio, cuando haya razones legales para hacerlo. No hay que olvidar que en las organizaciones criminales con frecuencia los servicios de buscapersonas y teléfonos celulares son contratados a nombre de terceras personas para distraer a las autoridades".

3. "Teléfonos celulares. Explorar la memoria de un teléfono celular para conocer los últimos números marcados o de llamadas recibidas, al igual que los mensajes dejados en el buzón, puede ser de mucha utilidad para conocer los contactos del usuario del aparato. De la misma manera es conveniente verificar con la empresa prestadora del servicio, a nombre de quién fue vendido el equipo telefónico, quién y de qué manera paga las cuentas, por las mismas razones anotadas al final del numeral precedente. La búsqueda en las memorias de los teléfonos celulares puede ser mucho más útil si se tiene en cuenta que ya se usan para hacer conexiones con la Internet, para envíos de correo electrónico y dentro de poco estarán en el mercado aparatos de esta especie que permiten la comunicación audiovisual".

4. "Computadores. No es extraño que cuando se produce la incautación de equipos electrónicos, particularmente computadores, las autoridades de policía, del Ministerio Público o judiciales intenten disponer a la mayor brevedad posible de ellos en el cumplimiento de funciones oficiales, para suplir así las carencias o necesidades que se padecen a este respecto. No obstante ello, lo aconsejable es procurar que, antes de hacer uso de tales equipos, se ordene y practique, con la ayuda de un ingeniero o experto en sistemas, con el fin de buscar en la memoria información que pueda ser útil a los fines de la investigación, no sólo en los archivos corrientes, sino en los buzones de correo electrónico, servicios de Internet (páginas personales o comerciales consultadas) e incluso en las memorias de cámaras de video que hayan sido conectadas con el fin de tener comunicación audiovisual a gran distancia.

En el mismo sentido debe recomendarse que, aún en el caso de que no se encuentre información en 
la memoria de un computador por haber sido borrados, se procure explorar la memoria printer desde donde es posible la recuperación de archivos para los cuales se haya dado orden de impresión recientemente. La memoria RAM de la computadora es un área de almacenamiento a corto plazo para cualquier tipo de dato que la computadora está usando, pero también es el tipo más común de memoria que utilizan las impresoras. La memoria ROM conserva su contenido incluso cuando se apaga el computador, por eso se conoce como permanente y es utilizada además en calculadoras y dispositivos periféricos tales como las impresoras láser. Por esa razón fue que en 1994, cuando en un allanamiento se encontró una computadora e indicios de que recientemente se habían impreso archivos que alcanzaron a ser borrados, producida su retención la computadora fue llevada a Estados Unidos, donde expertos en informática pudieron recuperar de la memoria printer los archivos impresos, correspondientes a guías telefónicas, direcciones de funcionarios judiciales y de gobierno, placas de vehículos que ingresaban a la ciudad, etc., información que era utilizada por los miembros de una organización dedicada al tráfico de estupefacientes".

5. "Diskettes. El hallazgo de diskettes al lado de computadores, en los que puede guardarse información relacionada con actividades delictivas, debe tomarse con mucha cautela, pues ha habido casos en que uno o varios de ellos han sido deliberadamente contaminados con virus para destruir información, han sido dejados a propósito para que quien los encuentre, al intentar leer los archivos contenidos en esos discos blandos, destruya otros existentes en el disco duro y que pueden ser comprometedores de la responsabilidad penal que pueda tener el usuario o dueño del equipo.

En todo caso, es importante hacer el esfuerzo por inspeccionar y analizar los archivos contenidos en unidades de almacenamiento de información, tales como diskettes, discos del sistema Zip (grabadoras de discos especiales con capacidad para archivar aproximadamente unos 100 megabytes), discos ópticos o discos compactos".

6. "Discos ópticos. Considerados los cuantiosos recursos con que cuentan los narcotraficantes, lavadores de activos y en general la delincuencia organizada, pero también el incremento de la masificación de los medios informáticos, ya no es nada extraño encontrar archivos grabados en discos ópticos porque, dado su carácter de memoria auxiliar o "periféricos de almacenamiento masivo", les permite guardar archivos voluminosos que pueden mantener fuera de un computador y esconder más fácilmente. En efecto, los discos ópticos son removibles, tienen capacidad para almacenar masivamente datos en pequeños espacios, son portables y son más seguros en la conservación de los archivos porque la capa que los almacena es inmune a los campos magnéticos caseros".

7. "Palm Pilot. Además de las muy conocidas agendas de papel y electrónicas, el Palm es un organizador personal en el que se pueden almacenar direcciones, teléfonos, usar juegos sencillos, programar listados de cosas por hacer, escribir memorandos, pero además las versiones actuales 
permiten conectarse a Internet y recibir mensajes de correo electrónico. Si a ello se suma el uso cada vez más frecuente de la Internet y el correo electrónico para realizar actividades delictivas relacionadas con los estupefacientes y el lavado de activos, se hace mucho más importante dedicar mayor atención a este tipo de aparatos electrónicos cuando son portados por una persona indiciada de cometer alguna de esas conductas o son hallados en la escena de uno de tales delitos".

8. "Tarjetas telefónicas prepagadas. No se debe olvidar que, además del aumento del uso de los servicios telefónicos prepagados para llamadas nacionales e internacionales, en la actualidad también hay tarjetas de esta especie con terminales de computador, que pueden ser usadas para comunicarse con cualquier aparato de esa clase. Por esa razón lo más recomendable es obtener el auxilio de expertos en telecomunicaciones con el fin de tratar de obtener información relacionada con el uso que se les haya dado a esas tarjetas, de tal manera que, por lo menos, se obtengan elementos de juicio para interrogar a un imputado o a eventuales testigos".

9. "Tarjetas de débito. Ordinariamente son tarjetas expedidas por los bancos para hacer retiros en dinero efectivo de cuentas corrientes o de ahorro; las más conocidas tienen bandas magnéticas pero también pueden tener barras de acceso que al ser leídas permitan el ingreso a una determinada cuenta para realizar una transacción. Igualmente existen las e-cash o monederos electrónicos y smart cards 0 tarjetas inteligentes, que cuentan con terminales de computación o chips incorporados para almacenar unidades de valor que con anterioridad se han depositado o cargado a una cuenta, de tal manera que el usuario pueda hacer pagos o descuentos hasta agotar la cuantía depositada 0 disponible y "recargarla" con un nuevo depósito. Aunque las empresas que ofrecen los monederos electrónicos han establecido pequeñas cuantías máximas, no se puede descartar que las mismas puedan ser utilizadas para hacer pagos relacionados con actividades ilícitas".

10. "Tarjetas de crédito. Algo que se debe tener en cuenta es que en allanamientos o en poder de personas capturadas se encuentran tarjetas de crédito expedidas a nombre de un tercero, que en muchos casos son utilizadas por narcotraficantes (las entregan a empleados suyos para pagos de viajes, gastos personales, etc.), lavadores o para pagar sobornos. Mayor cuidado hay que tener ahora que se ha puesto en el mercado la tarjeta de crédito virtual (E-Card) específicamente diseñada para compras por Internet, pues no se trata de una tarjeta física sino de un simple número, que ni siquiera requiere anotarse sino que hasta se puede consultar en la página de Internet del banco que la expide, previo uso de una contraseña".

"Aunque no constituya propiamente un documento, un pedazo de papel con unas características determinadas en un momento dado puede llegar a constituir prueba de la culpabilidad o inocencia de una persona a quien se imputa una infracción al estatuto de estupefacientes. En efecto, en una oportunidad el descubrimiento de un pliego de papel de regalo al que le habían cortado un pedazo, dentro de un escritorio del Comando de Policía al que pertenecían dos agentes de policía, permitió 
establecer que éstos mentían cuando le atribuían a un individuo el porte de varias envolturas de cocaína base dentro de una caja de goma de mascar, pues el grabado del papel utilizado para las envolturas era el mismo del hallado en el escritorio de los agentes y además exhibía un corte en el que calzaban a la perfección los retazos utilizados para las envolturas cuyo porte se atribuía al imputado, quien en su indagatoria acababa de alegar que los uniformados le habían introducido la caja de chicles a su bolsillo".

"Otro ejemplo digno de mencionar consiste en la utilización de una fotocopia de una carta manuscrita, anónima pero con dos alias al final del texto, en la cual se delataba ante la DEA que una organización narcotraficante iba a enviar un cargamento de más de tres toneladas de cocaína a USA, por vía marítima y en unas condiciones especificadas en la carta, lo que efectivamente había ocurrido. Habiendo obtenido una copia informal, un fiscal dejó constancia de ello, ordenó la apertura de una investigación previa y, con base en solicitud de asistencia judicial, obtuvo copias de las pruebas relacionadas con la incautación del cargamento de cocaína y la captura de personas, como también se identificó al autor de la carta, quien rindió testimonio jurado, aceptó la redacción de la carta e informó sobre la manera cómo obtuvo la información."71

\subsection{La prueba testimonial}

Es el instrumento probático capaz de producir una representación de determinados hechos históricos, a través de la exposición oral del testigo que ha visto, oído o percibido a través de los sentidos el hecho alegado como ilícito y sobre la conducta, acciones u omisiones del imputado o imputados. Este medio de prueba hace posible trasladar al proceso una serie de hechos de la realidad que serán sometidos a las inferencias y valoración del juez para obtener la reproducción del hecho controvertido, y en materia penal uno de los medios de pruebas idóneos para la búsqueda de la verdad material.72

El testimonio, conforme a la doctrina sustentada por Hernando Devis Echandía, presenta las características siguientes:

"a) Es un acto jurídico conscientemente ejercitado; b) Es un acto procesal; c) Es un medio de prueba judicial; d) Consiste en una narración de hechos;"

Es un deber jurídico para con el Estado el rendir testimonio sobre el conocimiento que se tenga de los hechos que interesen en cualquier proceso sin que haya razones valederas para limitarlo al ámbito penal.73

Esta prueba testimonial dentro del sistema acusatorio adoptado en el ordenamiento jurídico dominicano, en cuanto al proceso penal, está regida en el Código Procesal Penal, en el título III del Libro IV sobre los Medios de Prueba, y está comprendida desde el artículo 194 al 203, vinculantes para toda la materia penal. 
Se establece el testimonio como una obligación, según la cual, toda persona tiene la obligación de comparecer a la citación y declarar la verdad de cuanto conozca y le sea preguntado, salvo las excepciones de ley4.

La persona llamada a testificar no está obligada a declarar sobre hechos que puedan comprometer su responsabilidad penal, lo que implica el derecho a no declarar en contra de sí mismo o de no autoincriminación, conforme al artículo 8, numeral 2, literal i) de la Constitución de la República Dominicana que dispone:" Nadie podrá ser obligado a declarar contra sí mismo". En igual sentido se expresa el artículo 8.2 y 3 de la Convención Americana sobre Derechos Humanos y el art. 14.3 del Pacto Internacional de los Derechos Civiles y Políticos, de aplicación directa e inmediata y que prevalecen sobre toda ley que les sea contraria.75

El principio es que el testigo debidamente citado está obligado a comparecer76.

Esta obligación general de testificar y de comparecer para satisfacer este deber sufre excepciones como son:

(a) Por la dignidad del cargo. Sobre este aspecto, el Art. 195 del Código Procesal Penal establece: Excepción a la obligación de comparecer. El Presidente de la República, el Vicepresidente, los presidentes de las cámaras legislativas, los jueces de la Suprema Corte de Justicia, el Procurador General de la República, el Presidente de la Junta Central Electoral, Ios embajadores y cónsules extranjeros, pueden solicitar que la declaración se lleve a cabo en el lugar donde cumplen sus funciones o en su domicilio;

(b) Por el carácter perjudicial de la declaración para quien la hace: "La persona llamada a testificar no está obligada a declarar sobre hechos que puedan comprometer su responsabilidad penal77, esta excepción entra dentro del ámbito del derecho a no auto incriminarse".

(c) El grado de parentesco o afinidad: En este caso se crea una facultad de abstención de presentar declaración: 1) Al cónyuge o conviviente del imputado; 2) Los parientes hasta el tercer grado de consanguinidad o segundo de afinidad, se prevé expresamente que antes de que presten testimonio estas personas deben ser advertidas de su facultad de abstención y pueden ejercer esta facultad en cualquier momento, aún durante su declaración, incluso para preguntas particulares. ${ }^{78} \mathrm{Si}$ el Juez 0 tribunal, y en su caso el Ministerio Público, estima que el testigo invoca erróneamente la facultad o el deber de abstención, ordena su declaración, conforme al citado Art. 194.

(d) Por razón del secreto profesional. El Art. 197 consagra el deber de abstención, según el cual deben abstenerse de declarar quienes según la ley, deban guardar secreto. Estas personas no pueden negarse a prestar su testimonio cuando sean liberadas por el interesado del deber de guardar secreto. Este principio sufre una excepción en materia de lavado de activos, de conformidad con el artículo 41.3 de dicha Ley, cuando se trata de profesionales liberales, que actúan en el ejercicio de su 
profesión como intermediario financiero; y en igual sentido, según el artículo 41.7, en razón del deber de colaboración con el Comité Nacional contra el Lavado de Activos, con respecto a cualquier hecho u operación en que exista indicio o certeza de que está relacionado con el lavado de activo, lo que implica que no hay reserva sobre el secreto bancario.

(e) Por el lugar de la residencia del testigo. El Art. 200 reglamenta en pro de la efectividad y aseguramiento del testimonio de los testigos residentes en el extranjero que se proceda conforme a las reglas de cooperación judicial internacional, pudiéndose requerir la autorización del Estado en el cual se encuentre la persona llamada a testificar, para que el representante consular o el Juez que conoce de la causa o por un representante del Ministerio Público, proceda a trasladarse a fin de ejecutar la diligencia según la fase del procedimiento y la naturaleza del acto de que se trate, innovación ésta aportada por el nuevo Código Procesal Penal, que facilita la prueba testimonial en un delito que como el lavado de activos se caracteriza por su naturaleza de crimen internacional, o sea, que su comisión se desarrolla o puede desarrollarse en territorios de diferentes Estados. Ya sea el lavado de activos en sí mismo o los crímenes anteriores que lo facilitan o encumbren.

Testimonios especiales. Tal es el testimonio de personas que se encuentren en circunstancias especiales de vulnerabilidad, cuyo testimonio puede ser recibido en privado y con la asistencia de familiares o personas especializadas. ${ }^{79}$

(h) Testimonio de los menores de dieciocho años de edad, ya sean niños y niñas (hasta los doce años) y adolescentes (desde los trece años hasta alcanzar la mayoría de edad), que son utilizados por los inculpados en el delito internacional de lavado de activos, y por los derechos propios de esta franja de la población, con la categoría de derechos humanos, y por consiguiente de naturaleza constitucional. En esa categoría están los derechos consagrados en la Declaración Universal de los Derechos del Niño y en el Nuevo Código del Menor8o

Partiendo de estos principios, el testimonio de los menores está sujeto a la siguiente regulación, según el art. 327 del Código Procesal Penal: Siempre que el interrogatorio puede perjudicar la serenidad del menor de edad, a petición de parte o de oficio, el tribunal puede disponer uno o más de las siguientes medidas: 1) Escuchar su declaración sobre la base de las preguntas presentadas por las partes; 2) La celebración a puerta cerradas de la audiencia; 3) Que el menor declare fuera de la sala de audiencia y que se dispongan los medios técnicos que permitan a las partes y al público a presenciar el interrogatorio desde la sala. Esta declaración puede ser revocada durante el transcurso de la declaración.

Durante este testimonio especial el presidente puede auxiliarse de un pariente del menor, de un experto en psicología o de otra ciencia de la conducta.

(i) Testimonio de personas que no hablen español o con impedimento. No es una causa inhabilitante para 
ser testigo el hecho de que se trate de personas que no puedan expresarse fácilmente en español 0 que adolezcan de algún impedimento manifiesto. Pueden disponerse las medidas necesarias para que el interrogado sea asistido por un intérprete o traductor o se exprese por escrito o de la forma que facilite la realización de la diligencia, en virtud del Art. 202 del Código Procesal Penal.

(j) Testigos residentes en lugar lejano del tribunal: Si el testigo reside en un lugar lejano de donde deba prestar declaración y carece de los medios económicos para su traslado, puede disponerse la provisión de los medios económicos necesarios para asegurar su comparecencia, estando garantizada la comparecencia mediante la sanción de conducencia. 81

(k) Testimonio del testigo reticente: Salvo las excepciones indicadas precedentemente, se garantiza la comparecencia del testigo, denominado testigo reticente, que es aquel que citado para prestar declaración no comparezca o se niega a satisfacer el objeto de la citación. En ese caso es sancionado con una multa por el equivalente de hasta treinta días de salario base por un Juez de primera instancia. Esta sanción la aplica el Juez a solicitud del Ministerio Público. 82

La forma extrema de conminar al testigo a cumplir con su deber de testificar es la conducencia que procede en el caso en que si debida y regularmente citado el testigo no se presenta a prestar declaración, el Juez o tribunal o el Ministerio Público, durante el procedimiento preparatorio, puede hacerle comparecer mediante el uso de la fuerza pública.

La conducencia no puede prolongarse más allá del agotamiento de la diligencia o actuación que la motiva. 83

La prueba testimonial como todo medio de prueba está sujeta a ser aportada conforme a los principios de la legalidad de la prueba, a la contradicción, a la oralidad o sea, ser producida en presencia de toda las partes, a viva voz, y en conformidad con el principio de inmediatez, con la presencia continua de las partes y el Juez, que permitirá la observaciones, impugnaciones, argumentaciones, con respeto a la dignidad de la persona del testigo y contra quien o a favor de quien se exponga el testimonio, que se refiera directa o indirectamente al hecho y circunstancias objeto de la actividad probatoria, o sea, la pertinencia y utilidad para descubrir la verdad. En el Art. 201 de dicho Código Procesal se regula la forma de la declaración, como sigue: Antes de iniciar su declaración, el testigo es informado sobre sus obligaciones y de la responsabilidad derivada de su incumplimiento de, según su creencia, prestar juramento o promesa de decir la verdad.

Acto seguido procede su interrogatorio por separado, que se inicia con las preguntas acerca de sus datos personales y cualquier otra circunstancia que sirva para apreciar la veracidad de su testimonio.

Si el testigo expresa temor por su integridad o la de otra persona puede ser autorizado excepcionalmente a no indicar públicamente su domicilio y otros datos de referencia, de lo cual se toma nota reservada, pero el testigo 
no puede ocultar su identidad ni ser eximido de comparecer.

Como todo instrumento probática o medio de prueba, el testimonio está sometido a la admisión y valoración de parte del Juez, a quien va dirigida la prueba, ya sea como instrumento o medio, o como los argumentos, razones y motivos dirigidos a convencer al Juez sobre la fiabilidad del medio de prueba, así como la verosimilitud de los hechos cuya prueba o demostración se pretende a través del testimonio. Este será sometido a las reglas de la lógica, a los principios científicos y a las máximas de experiencia para conformar la sana crítica del Juez o tribunal.

Estas investigaciones tendentes a la recolección de la prueba para ser sometidas al Juez a los fines de admisión, están rodeadas de las más estrictas regulaciones a los fines de asegurar la licitud y legalidad de la prueba y el respeto a la dignidad humana y al derecho de defensa, conforme a las disposiciones constitucionales prescritas en el Art. 8 que consagra el régimen de las libertades fundamentales y derechos humanos, como finalidad esencial del Estado Dominicano.

\subsection{La prueba informativa}

Sentis Melendo define la prueba de informes como "la que ha de practicarse para incorporar a los autos, por medio de escrito, datos que existan registrados en contabilidad o archivos de una entidad pública o privada que no sea parte de un juicio, destinados a comprobar afirmaciones relativas a hechos controvertidos y que se aporten por quienes representen a la entidad y cuyo conocimiento de tales datos no tenga un carácter personal". 84

Para Luís Muñoz Sabaté, la prueba de informes, sustancialmente, es aquella que tiene su fuente en un archivo, libro o registro de una entidad pública, la que puede extenderse a empresas privadas dotada de una macroorganización tal que haga más cómoda, fiable y operativa este tipo de prueba, añadiéndole como característica accidental la escasa influencia que sobre la misma pueda tener el principio del contradictorio, teniendo la contraparte como medio de oponerse a la misma la oportunidad de comprobar o infirmar la misma mediante la prueba en contrario, ya sea solicitando otros datos informativos, rechazarla o desviarla hacia la prueba testifical. 85

Estos informes, como medios de prueba, son de uso cotidiano en los procesos judiciales, especialmente en la materia penal, hasta el punto que puede constituir la casi totalidad de la estrategia probatoria.

La prueba de informes en el derecho procesal dominicano en materia de lavados de activos tiene un fundamento legal. 
Con relación a este instrumento de prueba, la Ley 72-02 sobre Lavado de Activo, establece en su capitulo IV la obligación de la prevención y detección del lavado de activos constituyendo la figura de los "sujetos obligados", para:

(a) Las entidades financieras legalmente reguladas;

(b) Las personas físicas o morales dedicadas al corretaje o intermediación de títulos o valores, de inversiones y de ventas a futuros;

(c) Las personas físicas o morales que intermedien en el canje de divisas (agentes de cambio, canjeadores);

(d) Banco Central de la República Dominicana.

El artículo 39 de dicha Ley expresa que se asimilarán a las instituciones financieras las personas físicas 0 morales que realicen, entre otras, las siguientes actividades:

(a) Operaciones sistemáticas de canje de cheques u otro tipo de valor negociable;

(b) Operaciones sistemáticas de emisión, venta o rescate de cheques de viajeros o giro postal, la emisión de tarjetas de créditos o débitos y otros instrumentos similares.

(c) Transferencias sistemáticas de fondos, sea por vía de las entidades financieras, por correos especiales, por medios electrónicos o cualquier otro medio (agentes de cambios, remesadores).

(d) Cualquier entidad que preste servicios financiero internacionales (offshore).

Quedando también sujetas a las obligaciones establecidas en el presente capitulo las personas físicas 0 jurídicas que ejerzan otras actividades profesionales o empresariales particularmente susceptibles de ser utilizadas para el lavado de activos. Se considerarán como tales, conforme al Art. 40 de la citada Ley,

(a) Los casinos de juegos;

(b) Las actividades de promoción inmobiliaria o compraventa de inmuebles;

(c) Las empresas o personas físicas que de forma habitual se dediquen a la compra y venta de artículos;

(d) Compañías y corredores de seguros;

(e) Las actividades comerciales, en atención a la utilización habitual de billetes u otros instrumentos al portador como medio de cobro, al alto valor unitario de los objetos o servicios ofrecidos, o a otras circunstancias relevantes. Sin que sea limitativa, entre esas actividades figuran la compra y venta de armas de fuego, metales, artes, objetos arqueológicos, joyas, barcos, aviones;

(†) Los servicios profesionales; 
(g) Cualquier otra actividad comercial que, por la naturaleza de sus operaciones, pueda ser utilizada para el lavado de activos.

En el Art. 41 de la Ley 72-02, se establecen como obligaciones de los "sujetos obligados" Ias siguientes:

Identificación de clientes; e

Identificación de terceros beneficiarios;

En el caso de los profesionales liberales que actúen como intermediarios financieros, no podrán invocar el secreto profesional para rechazar revelar la identidad de los terceros parte de la transacción;

Reporte de transacciones en efectivo, lo que implica para el sujeto obligado comunicar dentro de los quince (15) días de cada mes, mediante formularios o a través de soporte magnético a la Unidad de Análisis Financiero, vía Superintendencia de Bancos, a todas las instituciones que estén bajo la supervisión de esta entidad, todas las transacciones en efectivo realizadas en el mes anterior que superen la cantidad de diez mil dólares (US\$10,000.00) u otra moneda extranjera o su equivalente en moneda nacional, calculado en base a la tasa oficial de cambio establecida por el Banco Central de la República Dominicana. Asimismo, las transacciones múltiples en efectivo realizadas en una o más oficinas de la misma entidad que, en su conjunto, superen la cantidad de diez mil dólares (US\$10,000.00) de los Estados Unidos de América u otra moneda extranjera o su equivalente en moneda nacional, serán agrupadas y consideradas como una transacción única si son realizadas en beneficio de una misma persona, física o moral durante un día laborable y cuyas transacciones deberán ser reportadas a la Unidad de Análisis Financiero.

Transacciones sospechosas, las cuales son definidas en el literal 5 del referido Art.41.

Conservar los documentos durante un periodo de mínimo de diez (10) años que acrediten adecuadamente la realización de las operaciones y la identidad de las personas físicas o morales que las hubieran realizado 0 que hubieran entablado relaciones de negocio con la entidad.

Colaboración con el Comité Nacional contra el Lavado de Activos, como es comunicar por iniciativa propia o por solicitud del Comité Nacional contra el Lavado de Activo cualquier hecho u operación respecto al que exista indicio o certeza de que está relacionado con el lavado de activos.

Estas disposiciones sobre la prevención y detección del lavado de activo implica necesariamente el deber de los "sujetos obligados" de rendir informes sobre las actividades que realizan y que están legalmente definidas en la Ley 72-02, cuando les sean requeridas por los agentes administrativos y autoridades judiciales competentes, para los fines de fundamentar la acusación correspondiente como medios de prueba idóneos. 
En cuanto a la naturaleza de este medio de prueba, Sentís Melendo la califica de prueba sucedáneo a la prueba testifical. Para Serantes Peña es un complemento de la prueba testifical, Almagro Focet la considera como "una síntesis de diversos elementos de prueba que se configuran de manera unitaria"; y para Luís Muñoz Sabaté, la prueba de informes es "un testimonio de altura, despersonalizado y manifiestamente objetivo que depone usualmente sobre datos registrados o máximas de experiencia. 86

Como prueba sucedánea a la testifical el "sujeto obligado" o su representante legal, si es una persona moral, puede ser llamado a testificar, en calidad de testigo, según sus derechos y obligaciones expuestos más arriba.

\subsection{El peritaje}

Es el medio de prueba, particularmente empleado para transmitir y aportar al proceso nociones técnicas y objetos de prueba, para cuya determinación y adquisición se requieren conocimientos especiales y capacidad técnica.

El peritaje es el medio de prueba idóneo cuando en el proceso penal se presentan cuestiones para cuya solución es preciso poseer determinados conocimientos científicos, técnicos o artísticos, para comprobar hechos de cierta naturaleza, por ejemplo en los casos de violación, establecer en el caso de lavado de activos, el encubrimiento de los hechos delictivos previos al lavado, por medio de la moderna tecnología en el ámbito digital, y sus consecuencias económicas en la industria del entretenimiento; configurar las características de algunos hechos para dejar tipificada la infracción como en las asociaciones del crimen organizado, su naturaleza, características, modo de operar, etcétera. 87

Como analizaremos, en el nuevo Código Procesal Penal se hace una detallada reglamentación, que viene a suplir los vacíos y lagunas de este medio de prueba fundamental para la consecución de la verdad judicial, en sus artículos del 204 al 217 y 324.

Se conceptúa el peritaje como el medio para descubrir o valorar un elemento de prueba cuando sea necesario poseer conocimientos especiales en alguna ciencia, arte o técnica, cuya prueba debe ser practicada por expertos imparciales, objetivos e independientes88 (Art.204).

Los peritos deben estar dotados de calidad habilitante: deben ser expertos y tener títulos, expedidos en el país $o$ en el extranjero, sobre la materia relativa al punto sobre el cual son llamados a dictaminar, siempre que la ciencia, arte o técnica estén reglamentadas. En caso contrario, debe designarse a personas de idoneidad manifiesta. 
No rigen las reglas de la prueba pericial para quien declare sobre hechos o circunstancias que conoció directamente, aunque utilice para informar las aptitudes especiales que posee en una ciencia, arte o técnica. En este caso se aplican las reglas de la prueba testimonial. 89

Están incapacitados para actuar como peritos:

(a) Quienes por insuficiencia o alteración de sus facultades mentales no comprendan el significado del acto;

(b) Quienes deban abstenerse de declarar como testigos;

(c) Quienes hayan sido testigos del hecho objeto de procedimiento;

(d) Los inhabilitados.

Un aspecto que debe destacarse en cuanto al nombramiento de los peritos, es que expresamente deben ser designados por el juez o tribunal, o por el Ministerio Público en la etapa preparatoria, siempre que no se trate de un anticipo jurisdiccional de prueba. Se determina el número de peritos según la complejidad de las cuestiones planteadas y se oyen las sugerencias de las partes 90 . Se atribuye facultad a las partes de proponer peritos en reemplazo del ya designado o para que dictamine conjuntamente con el nombrado por el tribunal; pudiendo las partes proponer temas para el peritaje y objetar los admitidos o propuestos por otra parte (Art.208). En apoyo al derecho constitucional de defensa, a las partes se les permite asistir a las diligencias, asesoradas por sus consultores técnicos, solicitar aclaraciones, con la obligación de retirarse cuando los peritos inicien sus deliberaciones. ${ }^{91}$

Se reglamenta lo relativo al dictamen pericial y, en caso necesario, nuevos dictámenes. Se ha creado la modalidad en la prueba pericial del "Auxilio Judicial"92, que consiste en que:

"El Juez o Ministerio Público, según la naturaleza del acto, puede ordenar la presentación o el secuestro de cosas y documentos, así como la comparecencia de personas, si fuere necesario, para llevar a cabo las operaciones de peritaje. También puede requerir al imputado y a otras personas que confeccionen el cuerpo de escritura, graben su voz o lleven a cabo operaciones semejantes.

Cuando la operación sólo pueda ser ejecutada voluntariamente por la persona requerida y ella rehúse colaborar, se deja constancia de su negativa y se dispone lo necesario para suplir esa falta de colaboración."

Otra innovación es la "Pericia cultural"93, en los casos de hechos punibles atribuidos a miembro de un grupo social puede ordenarse una pericia cultural para conocer las pautas culturales de referencia, a los fines de valorar adecuadamente su responsabilidad penal. 
En relación con la facultad de las partes en la práctica del peritaje, ellas pueden proponer otro perito en reemplazo del ya designado, o para que dictamen conjuntamente con él cuando por las circunstancias particulares del caso, resulta conveniente su participación, por experiencia o idoneidad especial.94

Las partes pueden proponer fundadamente temas para el peritaje y objetar los admitidos o propuestos por otra de las partes, es decir, que las partes tienen una participación pro activa en defensa de sus pretensiones siendo causas legales de inhibición y recusación de los peritos las establecidas para los jueces.

Ejecución del peritaje. Los peritos deben aceptar las funciones para las que han sido designados, son citados en la misma forma que los testigos y tienen el deber de comparecer y desempeñar el cargo para el cual han sido nominados.

Si los peritos no son idóneos, estando comprendidos en algunas de las incapacidades citadas, presentan un motivo que habilite su recusación o sufren un impedimento grave, así lo pueden manifestar, indicando los motivos.

El funcionario que ha dispuesto el peritaje resuelve todas las cuestiones que se planteen durante su realización.

Los peritos practican conjuntamente el examen, siempre que sea posible o conveniente. Las partes y sus consultores técnicos pueden asistir a la diligencia y solicitar aclaraciones pertinentes, con la obligación de retirarse cuando los peritos inicien la deliberación. Durante la etapa preparatoria, esta facultad no obliga al Ministerio Público a convocar a las partes a la operación.

Cuando algún perito no concurre a realizar las operaciones periciales, por negligencia o por alguna causa grave, o cuando simplemente desempeña mal su función, se procede a su reemplazo.

\section{Dictamen Pericial}

El dictamen debe ser fundado y contener la relación detallada de las operaciones practicadas y sus resultados, las observaciones de las partes o de sus consultores técnicos, en su caso, y las conclusiones que se formulen respecto de cada tema estudiado.

Los peritos pueden dictaminar por separado cuando exista diversidad de opiniones entre ellos. El dictamen se presenta por escrito firmado y fechado, sin perjuicio del informe oral en las audiencias.

Cuando el dictamen es dudoso, insuficiente o contradictorio, el Juez, a solicitud de parte, o el ministerio publico, 
según corresponda, pueden ordenar su ampliación o la realización de un nuevo peritaje por los mismos peritos o por otros. 95

Para la verificación y valoración del hecho punible o uno de sus elementos, conforme a los principios cientíicos, artísticos o técnicos, el nuevo Código Procesal Penal ha creado el mecanismo del auxilio judicial, que para su implementación requiere:

(a) De la orden del Ministerio Público, en la fase de investigación o del Juez, según la naturaleza del acto de presentación o secuestro de casos y documentos;

(b) Ordenar la comparecencia de personas, si es necesario, para realizar las operaciones de peritaje; y

(c) Ordenar al imputado y a otras personas que confeccionen el cuerpo de escritura, que graben su voz y otras operaciones semejantes, eficaces para la verificación y valoración de la prueba en el campo del lavado de activo y crímenes graves que lo preceden. 96

Los dictámenes de los peritos no son vinculantes para el Juez, que conserva la libertad de apreciación y valoración de la prueba, lo que debe ser conforme a la regla de la sana crítica y debe fundar su decisión en una interpretación de los hechos de conformidad con los principios científicos, normas de experiencia y las reglas de la lógica.

\subsection{La prueba anticipada}

Es un tipo de prueba que presenta las siguientes características:

(a) Es de naturaleza preventiva, por la no existencia del proceso penal en el momento en que se van recogiendo o elaborando los datos, que recaen sobre operaciones de naturaleza sospechosa que apuntan hacia la comisión de un hecho punible, no precisamente de carácter subjetivo o sea sobre persona o personas determinadas, y como modelo de las mismas se tienen las verificaciones de operaciones o transacciones económicas indicadas taxativamente en los artículos 38 al 40 de la citada Ley 72-02 sobre Lavado de Activos.

(b) Carácter preconstituido, o sea, antes de la formulación de la acusación y del inicio del proceso, con el objeto de constituir o formar las pruebas con base en las cuales se fundamente la acusación.

(c) No existe certeza de la existencia de un hecho punible.

(d) Se origina con autorización legal97 o judicial, como en el caso de la interceptación de telecomunicaciones. 98

(e) Las pruebas anticipadas pueden tener por objeto preconstituir: la prueba de informes99; la prueba 
testimonial; la prueba documental como fotografías, grabaciones de audio o video, soportes magnéticos, actas de incautación de drogas, de allanamiento de moradas o lugares privados y/o lugares públicos, etcétera.

En el campo de lavado de activo las actividades tendentes a preconstruir la prueba son asignadas por la ley, a organismos o funcionarios, como en el caso de los reportes de transacciones en efectivo por las entidades bancarias bajo la supervisión de la Superintendencia de Bancos, destinadas a las Unidades de Análisis Financiero, conforme con el Art.41.4 de la Ley 72-02.

Puede afirmarse que con base a una prueba anticipada, que sólo puede constituirse para una actividad especificada por la ley o la autoridad judicial, que le da veracidad y fiabilidad a los datos verificados, y de naturaleza excepcional frente al principio de la presunción de inocencia, el agente oficial o los "sujetos obligados", de conformidad con la terminología de la Ley 72-02, empiezan a preconstituir pruebas de lo que puede ser un hecho punible, que serán el fundamento de la imputación o acusación y de la eventual condena penal.

Como señala Hernán Rincón Cuellar, especialista legal CICAD/OEA, "en el campo penal y particularmente en las investigaciones relacionadas con el lavado de activos, tráfico ilícito de estupefacientes, de precursores, de armas, cabe la posibilidad de preconstituir pruebas sin que implique vulneración de derechos o garantías del individuo, con amparo en leyes y tratados internacionales." 100

El Código Procesal Penal tipifica la figura procesal del "anticipo de prueba", según el Art. 287, "excepcionalmente las partes pueden solicitar al juez un anticipo de prueba cuando:

1. Se trate de un peritaje que por sus características no permita que se realice posteriormente un nuevo eximan:

2. Es necesaria la declaración de un testigo que, por algún obstáculo difícil de superar, se presuma que no podrá hacerse durante el juicio 0, cuando por la complejidad del asunto, exista probabilidad de que el testigo olvide circunstancias esenciales sobre lo que conoce.

El juez practica el acto, si lo considera admisible, y cita a las partes, que tienen derecho a asistir, y a hacer uso de la palabra con autorización del Juez. En todo caso, las partes presentes pueden solicitar que consten en el acta las observaciones que estiman pertinentes, incluso sobre irregularidades e inconsistencias del acto.

El acto se registra por cualquier medio fehaciente y será conservado por el Ministerio Público, sin perjuicio de que las partes se puedan hacer expedir copia." 
La prueba anticipada tiene una naturaleza diferente "al anticipo de prueba". Aquellas es usada cuando se aporte información de que se puede estar cometiendo un delito sin que haya la certeza de la existencia de un hecho punible, sin estar iniciado un proceso penal y se ponen en ejecución con la autorización legal expresa o de las autoridades judiciales. En el ordenamiento jurídico dominicano, la autorización nace de la Ley 72-02 referida como una obligación de la prevención y detección del lavado de activos.

Por otra parte, que en el supuesto del "anticipo da prueba" se formaliza con posterioridad a la comisión del hecho punible y en la fase de la investigación, según resulta del artículo 287 del Código Procesal Penal transcrito.

La prueba anticipada como el anticipo de pruebas son modalidades de aseguramiento de la prueba.

\subsection{El valor de los indicios}

El indicio es la prueba racional o crítica en el proceso penal y su incidencia en los procesos por tráfico ilícito de drogas, delitos graves y conexos.

(a) Noción de prueba indiciaria

"Indicio, de la voz latina indicium, derivación de indecire que significa indicar, hacer conocer algo.

Esta función la cumple el indicio en virtud de la relación lógica que exista entre el hecho indicador y el hecho indicado, es decir, sin que medie ninguna representación de éste, ni oral, ni escrita, ni por reproducción de imágenes o sonidos, como resulta del testimonio y del documento.

Por lo que se entiende por indicio: un hecho conocido del cual se induce otro hecho desconocido, mediante un argumento probatorio que de aquel se obtiene, en virtud de una operación lógica-crítica basada en normas generales de la experiencia o en, principios científicos." 101

Es denominada la prueba indiciaria como crítica, racional o aún presuncional porque se trata de extraer, a través de un razonamiento lógico de orden racional, una inferencia que permita descubrir el hecho desconocido (el delito) de una serie de hechos conocidos (hechos base) perfectamente acreditados en el juicio.

Se la define como las cosas, estados o hechos personales o materiales, ocurridos o en curso, aptos para convencer acerca de la verdad de afirmaciones o de la existencia de hechos objeto del proceso.

Se la clasifica entre las pruebas de carácter indirecto, de tipo residual (real o personal) de la que se puede 
extraer una inferencia que permite formar un juicio de culpabilidad.

En el artículo 4 de la Ley No.72-02 sobre lavado de activos, se consagra de manera expresa la prueba indiciaria, como elemento probatorio, al referirse a las actividades delictivas tipificadas en el artículo anterior, que ya han sido analizadas, así como a los casos de incremento patrimonial derivado de las actividades delictivas con la frase de que podría inferirse de las circunstancias objetivas del caso.

Siguiendo con el texto de la Ley 72-02, los indicios o hechos conocidos, fuente de la inferencia probatoria, pueden resultar del incremento injustificado del patrimonio de una persona sin actividad económica lícita conocida; de operaciones sospechosas independientes de su cuantía que pueda estar vinculada con operaciones propia del lavado de activos; y de operaciones bancarias complejas, insólitas, significativas, frente a patrones no habituales.

La prueba indiciaria, circunstancial o presuntiva, aunque es de naturaleza racional, tiene un fundamento objetivo. La inferencia se hace no de un texto abstracto y genérico sino de un hecho, de una cosa, de un acontecimiento exterior, que conforme a las reglas de la lógica y a los principio de la experiencia es por sí mismo verídico, como sería el incremento de un patrimonio en un tiempo breve, teniendo como titular una persona sin recursos económicos que justifiquen una inversión productiva. Éste indicio indicador está unido a operaciones bancarias, inmobiliarias sospechosas, registradas por los "sujetos obligados", conforme a la Ley de lavado de activos; con expedientes de tráfico de drogas en el extranjero, con sentencias dictadas por tribunales de otros Estados que ordenan el decomiso de bienes situados en el territorio nacional. Ahí concurren las condiciones para evaluar los indicios conforme a los siguientes criterios expuestos por el Dr. Miguel Langón Cuñarro:

"Que estén relacionados con el hecho que se trata de probar, y que concurran en número suficiente para hacer plena prueba, esto es que deben ser variados y múltiples, no bastando uno solo;

Que sean de real envergadura o gravedad, de modo que refieran contundentemente al tema central objeto de prueba, que no se trate de minucias o asuntos colaterales o intrascendentes, o de detalle;

Que resulten inequívocos, concordantes, no contradictorios entre sí, no colindentes unos de otros, que sean precisos y lleven a una misma conclusión;

Que haya entre ellos una concatenación o ligazón lógica que permita realizar la inferencia sin dificultad y sin artificio de ninguna especie, como conclusión que fluye natural y libremente de la simple acumulación de pruebas; 
Que estén plenamente probados cada uno de ellos, que en su articulación se pueda afirmar que cada uno de ellos es una prueba material.

Para dicho autor, "Ios indicios pueden ser genéricos, derivados de la conducta anterior del imputado, de su "modus operandi" etc. Así por ejemplo, indicio de que el individuo está lavando dinero actualmente y que esa es la conducta que lo lleva a transportar una gran cantidad de dinero en efectivo, puede serlo, además de lo visto, el hecho de que en el pasado hubiera sido condenado por tal delito o que hubiera estado involucrado de algún modo con narcotraficantes o con personas vinculadas al lavado de activos de cualquier naturaleza, o que frecuente a individuos que se dedican a tal tarea, etc. Es decir, de los antecedentes del sujeto, eventualmente de los registros policiales, de las denuncias recibidas con anterioridad que lo sindicaban como vinculado a tal tipo de actividades, pueden servir actualmente para configurar un indicio de que está reincidiendo en tal actividad."

"De algún modo los prontuarios, registros de antecedentes, historias de vida, la "conducción de su vida pasada", pueden echar luz sobre su involucramiento presente en un delito de tal naturaleza, de forma que, junto a otros pueda constituir al cabo plena prueba de lavado."

"Por indicios específicos se entiende los referidos especialmente al hecho en cuestión, en el ejemplo anterior serían tales como: el hecho de manejar dinero en efectivo, en grandes e inusuales cantidades, en billetes de baja denominación, sin poder dar una explicación satisfactoria sobre su origen ni sobre el destino que se le pensaba dar o sobre el modo particular de transportación, por ejemplo en un doble fondo, oculto entre otros."

"Como toda prueba los indicios pueden ser negativos (o de descargo, o colidentes, acreditadores de las coartadas o alegaciones que se hubieren formulado), o positivos (o de cargo, concurrentes, confirmatorios de la tesis de la acusación)". 102

Por otra parte, sigue afirmando lo siguiente: "pero aquí, tal vez con mayor intensidad que en cualquier otra, los requisitos que se exigen para que la prueba de indicios llegue a ser, como puede serlo por si sola, plena prueba de delito y habilitadora por tanto de una sentencia de condena, son de estricto cumplimiento y de interpretación restrictiva, por lo cual la solidez de esta prueba debe estar acreditada de la mejor manera posible para impedir su destrucción y en definitiva su no consideración como plena prueba criminal". 103

Como ilustrativo por su objetividad, y dada la naturaleza de este trabajo y su utilidad práctica, se transcribe del Dr. Miguel Langón Cuñarro el Catálogo no cerrado, sino solo indicativo, de indicios de lavado de activos:

(a) manejo de dinero en efectivo: 
- El propio hecho de manejar efectivo. En el mundo actual es algo fuera de lo común el manejar en los negocios dinero en efectivo, y el transportarlo, sobre todo en grandes cantidades, por los riesgos que supone y por las dificultades que tiene operar de esa manera, teniendo a disposición un amplio menú de alternativas más convenientes para el interesado.

- La forma clandestina u oculta del traslado. La no declaración en aduanas, y sobre todo el hecho de Ilevarlo en maletas, o en otras formas inusuales de trasporte de dinero, por ejemplo, supone un hecho anormal, algo sospechoso de por sí, seguramente encubridor de algún hecho ilícito (quizás evasión de impuestos, desfalco contra la esposa o algún socio pero también producto de delitos con finalidad de legitimación).

- Origen injustificado, procedencia desconocida del dinero. Es verdad que el sujeto no tiene por que declarar en su contra, y puede permanecer callado o en silencio, sin que ello signifique una prueba en su contra. Pero cosa distinta es mantenerse callado ante una prueba material como es la que surge de los incisos anteriores, lo que no significa una inversión del onus probandi, sino simplemente la constatación de que el Estado ha adquirido elementos de cargo que solo está en las manos del imputado destruir, por lo cual si no lo hace, es decir si no desvirtúa la prueba acumulada, pudiendo hacerlo, se puede tomar a aquella como elemento suficiente, por acumulación de indicios y proceder a un juicio de condenación, prescindiendo en absoluto de su declaración.

- Destino desconocido, el cual, en concurrencia con todo lo anterior dibuja sin violencia laguna un cuadro incriminador.

- Medios de vida no acordes con la posesión de semejante riqueza constante y sonante. Esto se puede acreditar fehacientemente por el Fiscal o por el Juez, que con el auxilio de la policía pueden llegar a establecer un cuadro de vida real muy concreto para acreditar una disparidad evidente entre ese dinero que tiene en su poder y la forma de vida anterior que llevaran él y su familia. Se debe acreditar por ejemplo su condición de desocupado o de trabajador que recibe tal o cual remuneración o ingreso mensual; si es propietario de la finca donde vive o si es inquilino, en cuyo caso cuanto vale la vivienda o cuanto paga de alquiler; elementos de confort que la alhajan, si posee automóvil y su valor; eventualmente barrio en que habita; colegio al que van los chicos; movimientos de tarjetas de créditos que tenga; ingresos del núcleo habitacional, de forma y modo de establecer un cuadro vivencial del individuo y su núcleo más cercano (puede ampliarse a los padres si los tiene, a sus hermanos), educación, forma de emplear el tiempo libre, clubes a los que asista, cuentas bancarias que maneje etc., todo lo que puede llevar naturalmente a establecer que ese individuo con seguridad opera como testaferro de otro, a su servicio, porque la riqueza que exhibe (ese dinero en efectivo que se le incauta), no está en relación con su forma de vida, sus antecedentes, su status social. También aquí el sujeto podría evadir fácilmente las sospechas si tuviera una forma de acreditar la posesión de semejante riqueza, por ejemplo acreditando haber recibido una herencia, haber ganado un sorteo, etc. 
No es que su silencio sea utilizado en su contra, sino que la prueba ya aportada a los autos no ha sido conmovida por contraprueba válida, permaneciendo incólume junto con el resto de indicios que claramente lo comprometen, al grado de justificar una sentencia condenatoria, con la seguridad, dentro de las posibilidades de falencia humanas, de que estamos condenando a un lavado.

(b) manejo de cuentas corrientes

- fraccionamiento injustificado de las mismas, especialmente cuando existen controles por cantidades por ejemplo mayores a los diez mil dólares, este indicio consiste en probar que, sin aparente beneficio de ninguna especie para el supuesto cliente, éste abre numerosas cuentas en diferentes instituciones por valor inferior al que permite el control individual, asumiendo una incomodidad irracional y adoptando una conducta sospechosa e inusual;

- transferencias múltiples y en general inmediatas, de unas cuentas a otras.

- cobro de comisiones elevadas por servicios.

- cualquier operación atípica, novedosa, no tradicional, compleja, sin utilidad aparente.

- ausencia de negociación jurídica que las justifique, inexistencia de negocios sustentables a los que puedan atribuirse dichos movimientos.

- complicación innecesaria de las operaciones, intervención de numerosas sociedades en los movimientos.

- utilización de cuentas situadas en países considerados "paraísos fiscales", donde el individuo no tiene intereses reales y tangibles de ninguna especie.

Como dijo Mittermeir los indicios o circunstancias "son otros tantos testigos mudos, que parece haber colocado la Providencia, para hacer resaltar la luz de la sombra en que el criminal se ha esforzado en ocultar el hecho principal, como un fanal que alumbra el entendimiento del juez y le dirige hacia los seguros vestigios que basta seguir para llegar a la verdad" 104

Según Couture, el principio que exige valorar la prueba de acuerdo con "Ias reglas de la sana crítica" se aplica a todos los medios de prueba y no exclusivamente al testimonio. Por ejemplo, las presunciones del hombre y los indicios se basan en esas reglas de la sana crítica: "preceptos de higiene mental, que tienden a depurar la reflexión del Juez sobre los frecuentes equívocos en que puede incurrir. Para que el Juez pueda apreciar la "mayor o menor relación o conexión entre los hechos que la constituyen (presunciones no legales) y el que se trata de averiguar", con el carácter necesario que un solo indicio presente, o el valor de una sola presunción del hombre, o correlación, gravedad y precisión de varios indicios no necesarios, debe recurrir no solo a la lógica, sino a la psicología para el examen de sus propias reacciones e impresiones ante tales hechos. 
Desde la óptica de Francesco Carnelutti, la prueba indiciaria emerge de la definición de la ley dada en el Art.2727 del Código Civil italiano donde se habla de "hecho conocido" que sirve para procurar el conocimiento de un "hecho desconocido". Eso es lo que corresponde al Art. 1349 del Código Civil dominicano que define las presunciones como "Ias consecuencias que la ley o el magistrado deduce de un hecho conocido a uno desconocido". Así, en el juicio penal el hecho desconocido es precisamente el delito que se debe constatar si ha sido cometido, y a este tipo de prueba Carnelutti la denomina prueba crítica, que esta constituida por un hecho diverso, sobre el cual se infiere un juicio, o sea una afirmación o negación de lo que se trata de probar. Al respecto, es ilustrativo el ejemplo siguiente: si después de haber ocurrido el delito el sospechoso se ha dado a la fuga, esto implica contra él una prueba crítica positiva; en cambio, si en el momento en que el delito ha sido cometido, se encontraba en un lugar distinto de aquel en el que se ha cometido, esto constituye una prueba crítica negativa a su favor.

Es decir, que la prueba crítica nace de la vinculación entre dos hechos según la experiencia, o sea, de acuerdo con una ley sacada de la experiencia, lo que se denomina en el Art. 172 del Código Procesal Penal, "Ias máximas de experiencias". De ahí los peligros de la prueba indiciaria de donde se deriva su valor relativo, 0 sea que el vínculo entre el hecho conocido al desconocido es un vínculo de probabilidad, por lo que se habla de presunción, partiendo de su sentido etimológico que se deriva de "prae-sumere"o sea que alude a un conocimiento no definitivo, por lo que se recomienda al Juez prudencia en el manejo de este tipo de prueba en el sentido de que él no debe admitir más que presunciones "graves, precisas y concordantes", reglas que no están contenidas de manera expresa en el proceso penal, pero responden a principios esencialmente lógicos que deben ser asimilados por los jueces y juristas que operan en el proceso penal.

Es de gran utilidad para el juzgador y las partes en el proceso penal, adentrarse en el análisis seguido por Francesco Carnelutti sobre la clasificación hecha en prueba histórica, que es aquella mediante la cual se hace la representación del hecho delictivo pasado, ya sea mediante el testimonio, peritaje o documento. La misma se toma en el sentido de hacer presente algo que está ausente; y la prueba crítica, según se ha analizado más arriba, con su expresión en la prueba indiciaria; y presenta como vicios de la prueba histórica la falacia, que se resuelve en la no verdad del juicio, es el error intelectual, el cual se subsana con el incremento de la cultura del juzgador; y la falsedad, que es la no verdad en el concepto, existe mala fe, engaño, cuyo remedio reside en el terreno de la ética y en el jurídico, mediante su tipificación y sanción, como resulta del crimen de falsedad en escrituras públicas, el perjurio, entre otros. 105

Por consiguiente, el valor relativo de ambos tipos de prueba, la histórica y la crítica, se soslayan sus potenciales vicios, al poner el legislador a disposición del Juez, a través del principio de la libertad de la prueba, ambos tipos de pruebas, que se complementan para la adquisición de la verdad material por el juzgador. 
El razonamiento lógico al que debe someterse en la forma de pensar jurídicamente el juez es consustancial con la prueba indiciaria, ya que se trata de probar un hecho a través de otros considerados como indicios, o sea de inferencias ya sean inductivas o deductivas, y cuya determinación se realiza a través de máximas de experiencia o principios científicos, y de normas jurídicas, hasta llegar a una conclusión de certeza, por la combinación de indicios serios, precisos y concordantes, o sea, "que entre los indicios y sus consecuencias exista armonía o concomitancia que descarte la irracionalidad o gratuidad en la génesis de la convicción". 106

Vamos a cerrar la prueba indiciaria con la doctrina jurisprudencial, de alcance general, de la sentencia del Tribunal Constitucional de España que establece: "Si existe prueba indiciaria, el tribunal de instancia, deberá precisar, en primer lugar cuales son los indicios probados y en segundo término, como se deduce de ellos la participación del acusado en el tipo penal, de tal modo que cualquier otro tribunal que intervenga con posterioridad pueda comprender el juicio formulado a partir de tales indicios. Es necesario... pues que el órgano judicial explicite no sólo las conclusiones obtenidas, sino también los elementos de prueba que conducen a dichas conclusiones y el iter mental que le ha llevado a entender probados los hechos constitutivos del delito, a fin de que pueda enjuiciarse la racionalidad y coherencia del proceso mental seguido y constatarse que el tribunal ha formado su convicción sobre una prueba de cargo capaz de desvirtuar la presunción de inocencia". 107

\subsection{El valor de la declaración de un coimputado}

\section{Declaración de los coimputados}

El principio que rige la declaración del imputado es el de libertad de declarar, que es un derecho a declarar o abstenerse de hacerlo o suspender su declaración en cualquier momento del procedimiento, de conformidad con el Art. 102 del Código Procesal Penal. 108

En este caso procede la pregunta: ¿Puede uno de los coimputados rendir declaraciones sobre hechos que repercuten en el otro coimputado? 0 sea, ¿es jurídicamente admisible el testimonio de un coacusado?

Esta pregunta tiene relevancia no sólo desde el punto de vista teórico, sino práctico, por las consecuencias jurídicas inherentes al principio constitucional de que "nadie puede ser obligado a declarar contra sí mismo. 109 A este respecto hay dos posiciones procesales:

(a) Aquella que considera que se trata de individuos acusados de una misma imputación, o sea partícipes de los mismos hechos debatidos en el proceso, coacusados en un mismo delito o delitos conexos; 
(b) Aquella que estima se trata de coacusados llevados conjuntamente a juicio, pero no por la identidad de los delitos que se les atribuyan, ni por razón de la conexidad de diversos delitos, ya declarados.

En el caso de coacusados por un mismo hecho, la regla es que no se admita el testimonio de los coacusados por un mismo delito o delitos conexos, por el profundo interés que dada la comunidad y la conexión de la acusación tiene el coinculpado, por lo que el testimonio sería sospechoso.

Esta prohibición se fundamenta en el principio general del derecho procesal penal de: Nemo tenetur se detegere (nadie está obligado a delatarse a sí mismo), y al ser copartícipe en el mismo hecho o conexo, existe la posibilidad material de que al declarar sobre el mismo se esté obligando a declarar contra sí mismo o en todo caso de que su declaración sea interesada y que nada aporte en el descubrimiento de la verdad. De conformidad con el Art. 13 sobre No Autoincriminación: del Código Procesal Penal se establece:

"Nadie puede ser obligado a declarar contra sí mismo y todo imputado tiene derecho a guardar silencio. El ejercicio de este derecho no puede ser considerado como una admisión de los hechos o indicio de culpabilidad ni puede ser valorado en su contra". 110

La declaración del coimputado está sometida al principio establecido en el Art. 104 del Código Procesal Penal: "En todos los casos la declaración del imputado solo es válida si se hace en presencia y con la asistencia de su defensor."

Cuando se presenta un caso de comunidad del hecho, puede asimilarse a la prohibición constitucional de que nadie podrá ser obligado a declarar contra sí mismo.111

En el caso del coimputado en sentido amplio, o sea donde no existe el vínculo de la comunidad del delito, sino solo al hecho extrínseco y accidental del juicio, el testimonio debe aceptarse.

El Art. 312 establece que pueden ser incorporadas al juicio por medio de lectura: las declaraciones de coinculpados que se encuentren en rebeldía, registrados conforme a este Código. De ahí se infiere que la validez de las declaraciones del co-inculpado comparecientes al juicio y que haya manifestado su deseo de declarar queda regulada su declaración por el Art. 104 que prevé que, en todos los casos, la declaración del imputado sólo es válida si lo hace con la presencia y asistencia de su abogado.

La credibilidad de la declaración del coimputado queda bajo la soberana apreciación del Juez al valorar la prueba. 
Como la regla es que toda persona goza de capacidad para rendir testimonio, en el caso de absolución del acusado, sea por no haber cometido el hecho o porque el hecho no existe, conforme sentencia con autoridad de cosa juzgada, la declaración puede hacerse en la forma testimonial.

Según la doctrina española, la declaración del coimputado ha sido igualmente admitida como fuente de prueba siempre y cuando se cumplan determinadas circunstancias; lo que implica la ausencia de prejuicios dogmáticos.

Para fundamentar esta doctrina se cita la sentencia del T. S., Sala 2da. , 12 de mayo 1985, La Ley, núm. 1492:

"...Puede cuando menos estimarse como constitutiva de la mínima actividad probatoria de cargo... siempre que no concurran las dos circunstancias de que:

(a) Exista en la causa motivo alguno que conduzca a deducir, aunque fuere indirectamente, que el complicado haya prestado la declaración guiado por móviles de odio personal, obediencia a una tercera persona, soborno policial, mediante o a través de una sediciente promesa de trato procesal más favorable, etcétera.

(b) Que la declaración inculpatoria se haya prestado con ánimo de auto-exculpación". 112

La declaración del co-imputado está sometida, por tanto, a la limitación constitucional de la inviolabilidad del principio de la no autoinculpación, conforme al citado artículo 8, inciso 2, letra i) de la Constitución Dominicana y del artículos 8.2.g) de la Convención Americana sobre Derechos Humanos, que literalmente dice: "Derecho a no ser obligado a declarar contra sí mismo ni a declararse culpable; y en el mismo sentido el Art. 14.2.g); así como conforme con el principio en materia de testimonio de que toda persona tiene la obligación de comparecer a la citación y declarar la verdad de cuanto conozca y le sea preguntado, salvo las excepciones de ley, siendo éstas la facultad de abstención limitada a : el cónyuge o conviviente del imputado y los parientes hasta el tercer grado de consaguinidad o el segundo de afinidad; y el deber de abstención en el caso del deber llamada a testificar el de guardar el secreto profesional, el cual en materia de lavado de activos se ha liberado de este deber, de conformidad con el Art. 41.3 de la Ley No.72-2, más arriba transcrito.

En el Código Procesal Penal, en lo relativo a la prueba testimonial no existe una excepción expresa a la obligación de testificar de parte del coimputado, ni se le ha atribuido la facultad de abstención, por lo que este testimonio está regido por regla general de la legalidad de la prueba y su valoración conforme a la sana crítica, bajo la discrecionalidad y prudencia del juez o tribunal, conforme a lo expresado sobre este aspecto previamente. 


\section{Otros medios de prueba}

En el ámbito del lavado de activos constituyen medios de prueba no sólo para obtenerla sino para el aseguramiento de la prueba:

El secuestro de correspondencia: Siempre que sea útil para el establecimiento de la verdad, pudiendo el juez ordenar, por resolución fundada, el secuestro de la correspondencia epistolar, telegráfica o de cualquier otra clase, remitida por el imputado o destinada a él, aunque sea bajo nombre supuesto, siendo aplicable las limitaciones del secuestro de documentos. 113

Otro medio de prueba que concuerda con los avances tecnológicos utilizados para fines criminales es el de interceptación de telecomunicaciones, reguladas en el Art. 192 del Código Procesal Penal, para lo cual se requiere la autorización judicial para la interceptación, captación y grabación de las comunicaciones, mensajes, datos, imágenes o sonidos transmitidos a través de redes públicas o privadas de telecomunicaciones por el imputado o cualquier otra persona que pueda facilitar razonablemente información relevante para la determinación de un hecho punible, cualquiera sea el medio técnico utilizado para conocerlas. Se procede conforme a las reglas del allanamiento o registro.

La medida de interceptación de comunicaciones tiene carácter excepcional y debe renovarse cada treinta días, expresando los motivos que justifican la extensión del plazo.

La resolución judicial que autoriza la interceptación o captación de comunicaciones debe indicar todos los elementos de identificación de los medios a interceptar y el hecho que motiva la medida.

Otra novedad es que el informe pericial se puede incorporar al juicio por su lectura, sin perjuicio de que las partes soliciten la presencia del perito en la audiencia y que las partes y sus consultores técnicos pueden participar en el desarrollo del peritaje. 114

Además de la prueba documental, se han diversificados y revalorizados los documentos expresamente elaborados para la comprobación de las infracciones ya sean actas o procesos verbales, sometiéndolos a un mayor control de parte del Juez, lo que representa un reconocimiento y defensa de los derechos humanos y de las libertades fundamentales, para garantizar la preservación de la prueba, vital en la investigación, acusación y juicio en materia de lavado de activos. Como ejemplo se tienen las actas levantadas con motivo del registro de personas (Art.176); registros colectivos (Art. 177); registro de moradas y lugares cerrados; allanamientos. 115 


\section{Innovaciones en la legislación dominicana que diversifican el sistema probatorio}

Un análisis del sistema procesal adoptado en el ordenamiento jurídico dominicano, con la supremacía de la Constitución, como norma primaria, y los convenios, pactos, tratados y declaraciones internacionales que consagran derechos humanos, conformando el bloque de constitucionalidad; con la Ley 72-02 sobre Lavado de Activos Provenientes del Tráfico llícito de Drogas y Sustancias Controladas y otras Infracciones Graves, del 7 de junio del 2002, y en específico de la Convención de las Naciones Unidas contra el Tráfico llícito de Estupefacientes y Sustancias Psicotrópicas del 20 de diciembre del 1988 o Convención de Viena y demás instrumentos internacionales relativos al lavado de activos, así con el nuevo Código Procesal Penal, Ley 7602, que abrogó el Código de Procedimiento Criminal de la República Dominicana, del 27 de junio de 1884 y sus modificaciones, resulta desde el punto de vista del sistema probatorio que:

(a) La cooperación judicial internacional, la que es objeto de un trato individualizado en la legislación adjetiva dominicana, dedicándosele el capítulo IV, del Libro III, sobre la Actividad Procesal del Código Procesal Penal, en sus artículos 155 al 165, que ha sido tratado en el Módulo I precedente.

(b) En el nuevo Código Procesal Penal se regula expresamente el procedimiento para asuntos complejos, para cuya aplicación se requiere, a solicitud del Ministerio Público, la autorización del Juez, y dada las características de los asuntos complejos, como es la pluralidad de hechos, el elevado número de imputados y victimas o tratarse de delincuencia organizada, entre los cuales están comprendidos el crimen de lavado de activos, proveniente del tráfico ilícito de drogas o sustancias controladas y otras infracciones graves 116;

(c) Para el aseguramiento de la prueba se ha instituido en el Art. 371 del indicado Código Procesal Penal, la producción de prueba masiva, cuando sea indispensable el interrogatorio de numerosos testigos por el Ministerio Público, con los requisitos siguientes:

- Los interrogatorios pueden ser registrados por cualquier medio;

- El Ministerio Público autorizado asume la obligación de presentar un informe que sintetiza objetivamente las declaraciones ;

- $\quad$ El informe puede ser introducido al debate para su lectura; y

- El imputado puede requerir la presentación de cualquiera de los investigadores en preservación al derecho de defensa.

(d) Que se prescribe la unificación de querellas cuando el Juez o tribunal advierte un gran número de querellas separadas con idénticos intereses, lo que puede facilitar la verificación y valoración de los elementos de prueba. 
(e) Que se ha instituido para los procedimientos complejos la investigación bajo reserva equivalente al agente encubierto, que consiste en la facultad concedida por el Juez de la instrucción, a solicitud del Ministerio Público, de que uno o varios de los investigadores bajo su dirección, permanezca reservada su identidad, cuando sea manifiestamente útil para el desarrollo de la investigación; y cuyo plazo es fijado por el Juez en un plazo no mayor de seis meses, el cual es prorrogable si se renuevan los fundamentos de la solicitud. 117

El Ministerio Público autorizado a realizar la investigación bajo reserva tiene el deber de: i) Concluido el plazo, presentar al Juez un informe del resultado de las investigaciones; ii) Revelar la identidad de los investigadores, que pueden ser citados como testigo de juicio; y iii) El Ministerio Público es responsable directo de la actuación de los investigadores.

Que se ha creado el funcionario denominado Acusador Adjunto, en los casos complejos, que le da atribuciones al Procurador General de la República, a contratar los servicios de uno o dos abogados particulares, con las mismas condiciones de ley, para ejercer las funciones como Ministerio Público, para que actúen como acusadores adjuntos, con iguales facultades y obligaciones del funcionario al cual acompañan118, lo que facilita una investigación técnica más profunda;

(g) Otra innovación en el sistema procesal es instituir los Consultores Técnicos, de acuerdo a la particularidad y complejidad del caso, a proposición del Ministerio Público y demás partes intervinientes, al Juez o tribunal, que debe autorizarlos, conforme a las reglas aplicables a los peritos, sin que tengan éste carácter;

Los consultores técnicos tienen las funciones de: i) Asesorar en una ciencia, arte o técnica; ii) Presenciar las operaciones de peritaje, acotar observaciones durante su transcurso, sin emitir dictamen, y dejar constancia de sus observaciones; iii) Acompañar en la audiencia a la parte con quien colabora, auxiliarla en los actos propios de su gestión; y iv) Interrogar directamente a peritos, traductores o intérpretes, bajo la dirección de la parte a la que asiste.

En el espacio de la cooperación judicial internacional, en la fase de investigación el Ministerio Público puede coordinar las operaciones con las autoridades encargadas del Estado interesado, pudiendo formarse equipos de investigación conjunta, dirigidos por el Ministerio Público y controlado por los jueces. ${ }^{119}$

- La incorporación expresa de la prueba indiciaria, conforme con el Art. 4 de la referida Ley 72-02 sobre Lavado de Activo, según el cual el conocimiento, la intención o la finalidad en el delito de lavado de activos, podrían inferirse de las circunstancias objetivas del caso. 


\section{Conclusión}

El ordenamiento jurídico de la República Dominicana está cimentado en la Constitución de la República, que declara la nulidad de toda ley, decreto, resolución, reglamento o actos contrarios a Constitucional misma, lo que implica el control difuso de la competencia de todos los tribunales del orden judicial. Y en lo relativo a los actos están comprendidos las sentencias u otros actos relativos al proceso, como cualquier elemento de prueba en que se fundamente la acusación y la condenación.

El sistema procesal penal dominicano, pues, cuenta con las herramientas conceptuales y procedimentales, para asumir la lucha judicial, procesal o extraprocesal, contra del crimen organizado nacional o transnacional, en su faceta más tenebrosa del lavado de activo, tráfico de estupefacientes y delitos graves. Asimismo, posee los mecanismos judiciales, rodeados de las garantías y principios del debido proceso de ley, para enfrentar con eficacia y respeto a las garantías constitucionales, el lavado de activos en todas sus manifestaciones, condicionado a que el recurso humano que encarna las diferentes funciones, los operadores judiciales, desde la investigación, recolección y aseguramiento de las pruebas, la acusación y el aspecto jurisdiccional supere en dedicación, preparación intelectual y voluntad a los que se oponen a la "voluntad de la ley", bajo la premisa de que sin prueba legítima, idónea y suficiente no es posible fundamentar la acusación, pasar de ésta a la condenación de los sujetos del delito, ya sean autores o cómplices. Es decir, que la prueba debe tener la potencialidad, virtud y eficacia, para destruir la presunción de inocencia, base del sistema acusatorio y garantía procesal de naturaleza constitucional.

\section{Organismos estatales a los cuales el juez y el fiscal pueden pedir información en casos de lavado de activos}

Saber cómo es un valor agregado que puede significar la diferencia en la ejecución de cualquier tarea. Para un Juez o investigador es de vital importancia tener la certeza de que existen instituciones que por la naturaleza de sus operaciones pueden ser útiles tanto para aclarar como para estructurar un caso.

Los casos de lavado de activos son, por lo general, difíciles de estructurar y tienden a manifestar situaciones que requieren, para su comprensión, cierto nivel técnico que no necesariamente está incluido en la formación de un buen abogado. De ahí que, se hace necesario contar con el apoyo pericial de técnicos con formación y experiencia en campos muy ajenos al legal.

A continuación se detallan las instituciones de gran utilidad para desenmarañar un caso y aportar pruebas e ideas medulares en la estructuración del mismo. 


\subsection{Unidad de Análisis Financiero}

Se define como la estructura encargada de recibir, solicitar, analizar y difundir a las autoridades competentes los reportes de información financiera relacionados con las ganancias que se sospecha provienen del crimen 0 que están establecidas en su legislación o en su reglamentación nacional, con el fin de combatir el lavado de activos.

La Ley contra el Lavado de Activos Provenientes del Tráfico llícito de Drogas y Sustancias Controladas y Otras Infracciones Graves (72-02) en su Artículo 57, crea la Unidad de Análisis Financiero, como brazo ejecutor del Comité Nacional Contra el Lavado de Activos. Además de los roles citados en la definición, deberá mantener los registros de todas las transacciones transadas en efectivo cuyo monto supere los US\$10,000.00, su equivalencia en moneda nacional o en cualquier otro tipo de moneda; ofrecer apoyo técnico a otras autoridades competentes, en cualquier fase del proceso de investigación; organizar seminarios y entrenamientos que fortalezcan la capacidad preventiva, de detección y de cumplimiento por parte de los sujetos obligados, así como realizar inspecciones de verificación de cumplimiento e investigativas de ser necesario. Esto aplica para todos los sujetos obligados, estipulados en la ley.

\subsection{Banco Central}

Dadas sus funciones estipuladas en el Artículo 15 de la Ley Monetaria y Financiera (183-02), que son las de ejecutar las políticas monetaria, cambiaria y financiera, de acuerdo al programa monetario aprobado por la Junta Monetaria, este organismo es de vital importancia para todas las actividades económicas de un país. Más aún cuando representa parte de la estructura de lo que es la Autoridad Monetaria y Financiera120.

El manejo del comportamiento económico de todos los sectores ya sean productivos o de servicios (comerciales, financieros) hace de este organismo una fuente de información que puede resultar de gran valor complementario en los casos que respecto al lavado de activos pueda manejar un Juez o un fiscal.

La Ley contra el Lavado de Activos Provenientes del Tráfico llícito de Drogas y Sustancias Controladas y Otras Infracciones Graves (72-02), en su Artículo 38, literal d, tipifica al Banco Central como un Sujeto Obligado, esto con el espíritu de que se sujetara a la ley ante la posibilidad de que por razones monetarias coyunturales efectuara Operaciones de Mercado Abierto, a través de las que, con la emisión de Certificados de Participación, podría captar recursos del público. Además, de la capacidad de servir de banco corresponsal de otros bancos centrales y de bancos comerciales radicados en el extranjero'121. 


\subsection{Superintendencia de Bancos}

Este organismo es parte de la Autoridad Monetaria y Financiera (Ver Art.5, de la Ley 183-02), con la responsabilidad de supervisar las entidades de intermediación financiera y cambiaria. Además, dentro de su estructura opera el Departamento de Inteligencia Financiera, que no es más que una Unidad de Inteligencia Financiera para las entidades que están bajo su supervisión.

Toda información que se necesite de las entidades que conforman los sectores financiero y cambiario, debe ser obtenida a través de la Superintendencia de Bancos a fin de no violar lo legalmente establecido en torno al secreto bancario 122 .

Por otro lado, la Superintendencia de Bancos, está señalada como Autoridad Competente en el Artículol, numeral 2, de la Ley 72-02, y de hecho había sido tipificada como tal en el Decreto 288-96, Reglamento de la Ley Sobre Drogas y Sustancias Controladas (50-88). En tal sentido, el Departamento de Inteligencia Financiera es operativo desde 1997, teniendo bajo su responsabilidad la prevención del Lavado de Activos. En el año 2000, se ingresó al Grupo Egmont, lo que provee un instrumento para requerir y compartir informaciones con Autoridades Competentes de otras jurisdicciones extraterritoriales. Desde el año 2001 forma parte del Subcomité de Control Financiero del Comité Interamericano Contra el Terrorismo de la Organización de Estados Americanos (CICTE-OEA).

El uso de la Superintendencia de Bancos, como órgano de enlace con el sistema de pagos, está revestido de una vital importancia en la estructuración de cualquier caso de lavado de activos (movimientos de las cuentas, productos/servicios financieros o cambiarios que, en cualquier modalidad, pudiera mantener la persona jurídica o moral acusada o sospechosa). La mayoría de las transacciones que se efectúan en una economía hacen uso de los servicios ofrecidos por las entidades que están bajo la supervisión de dicha institución, por lo que las informaciones a obtener pueden complementar cualquier caso de lavado de forma real y cabal.

También puede ser utilizada como apoyo técnico en la interpretación de Estados Financieros o de un producto financiero.

\subsection{Dirección Nacional de Control de Drogas}

En función de su naturaleza y de las actividades que realiza, policía especial contra drogas, las informaciones a obtener de este organismo son importantes. Por ejemplo, si el sospechoso o acusado ha sido investigado, si tiene ficha delictiva, si ha tenido conexidad con alguna persona investigada, acusada o condenada por tráfico de drogas, entre otros. 
Aquí funciona la sede de la Policía Internacional (INTERPOL), por lo que también esto implica un instrumento adicional de mucha utilidad, cuando los casos son extra fronterizos. Además, pueden recibir apoyo técnico del Departamento de Investigación Financiera, que opera desde 1996.

\subsection{Dirección General de Impuestos Internos}

En esta institución del Estado pueden obtenerse datos vitales para una investigación, pues se podrá confirmar la existencia de una organización y los impuestos que ha pagado. En función de esto el investigador comparará la magnitud del negocio con los impuestos pagados, y de no coincidir se estaría en frente de un fraude o de un posible escenario de lavado de dinero.

Lo anterior aplica también para individuos, y atendiendo a sus ingresos y bienes se podrá comparar el nivel de impuestos pagados. Esa institución tiene a su cargo también, el registro de vehículos.

\subsection{Dirección General de Migración}

El disponer de las entradas y salidas del país de un sospechoso puede ofrecer informaciones adicionales que complementarían cualquier investigación, pues le podrían vincular aún más al caso.

\subsection{Registro Mercantil}

Disponer del registro mercantil da la certeza al investigador de la existencia de la empresa investigada, lo que no implica que este operando, pero allí se podrá obtener el registro de los accionistas, identificaciones numéricas y domicilios, con lo que el investigador establecerá vinculaciones, al tiempo de mejorar la calidad investigativa.

\subsection{Contraloría General de la República}

Cuando la investigación toque a una institución del Estado, la Contraloría General de la República es un organismo que puede ser de gran utilidad, pues a través de sus operaciones el investigador podrá constatar detalles relativos al control interno, manejo financiero, ejecución presupuestaria, entre otras variables que unirá a las que dispone.

\subsection{Cámara de Cuentas}

Siendo el órgano de verificación externa posterior de las instituciones centralizadas y autónomas del Estado, su importancia es vital al momento que una investigación implique a las mismas. 
Los informes evacuados por la Cámara de Cuentas son ideales para fines comparativos en un proceso investigativo, pues podrían arrojar la luz que necesite el investigador para completar el caso.

\subsection{Oficina Nacional de Propiedad Industrial}

El uso de patentes de fachadas o fantasmas o el registro de un nombre comercial es una forma que se puede perfilar en un esquema de lavado de activos o de un crimen financiero, de ahí la importancia de que el investigador pueda contar con una institución en la que pueda verificar la propiedad de marcas o nombres de productos que se vinculen al caso investigado.

\subsection{Superintendecia de Valores}

El mercado de valores puede ser utilizado para lavar activos y para la comisión de crímenes financieros de alta sofisticación. El investigador, puede contar con la ayuda del organismo supervisor, que tiene la responsabilidad de aprobar las emisiones públicas de títulos valores, además de garantizar la correcta operación del mercado y sus componentes.

A través de este organismo el investigador podrá obtener todas las informaciones que requiera tanto de una emisión de valores como de una inversión en los mismos.

\subsection{Otras Fuentes de Información Estatales}

El investigador puede apelar a otras fuentes que le pueden ser útiles en el proceso investigativo. Por ejemplo, cuando desee comprobar la adquisición, venta, garantías, otros dueños o cualquier información trascendente relativa a un bien inmueble es de rigor que acuda a la Oficina del Registrador de Títulos.

Si desea investigar quién ha construido un edificio y de ahí determinar de dónde proviene el capital que lo ha financiado, puede obtener la información en las Oficinas de Catastro de los Ayuntamientos Municipales o en la Secretaría de Estado de Obras Públicas.

Para el caso de verificar pólizas de seguro, pueden ser verificadas a través de la Superintendencia de Seguros, así como los pagos y movimientos de dinero efectuados a Administradoras de Fondos de Pensiones, en la Superintendencia de Pensiones. 


\section{Organismos Privados de Utilidad Informativa}

Todo aquel que genere una actividad comercial es un Sujeto Obligado al amparo de la Ley 72-02 (Ver artículos Nos. 38, 39 y 40). En tal sentido, tal y como lo estipula la citada Ley en su artículo No. 13, para los fines de cumplimiento y debida diligencia no existe el amparo del secreto bancario, ni el secreto profesional, por lo que toda persona física o jurídica tiene el deber de proveer todas las informaciones que le sean requeridas. Estas informaciones pueden ser verificadas, por las vías legalmente establecidas, en el sitio que fueron generadas.

\subsection{Entidades de Intermediación Financiera y Cambiarias}

Este es, sin dudas, el campo más fértil de informaciones en los procesos investigativos de lavado de activos, pues el producto que comercializan estas entidades es el dinero. De aquí su importancia, vulnerabilidad y la razón por la que todos los enfoques preventivos se inician con estos sectores.

De éstas el investigador puede obtener: movimientos de todas las cuentas que en cualquier modalidad tengan o hayan tenido registradas, destinos de los fondos, fechas, vinculaciones, tipo de relación comercial, entre otras informaciones. Para lograrlo deberá utilizar los canales pertinentes identificando a la persona física o jurídica investigada con su(s) nombre(s) y apellido(s), número de cédula de identidad y electoral o pasaporte y nacionalidad en caso de que sea extranjero(a), razón social, número del registro nacional de contribuyente o su equivalente si está establecida en otra jurisdicción territorial.

Toda información que se necesite de las entidades de intermediación financiera y cambiarias debe ser solicitada a través de la Superintendencia de Bancos, como Autoridad Competente responsable del sector que supervisa ${ }^{123}$.

La Superintendencia de Bancos no tiene un rol de filtro o cedazo de informaciones sino de intermediaria entre las demás Autoridades Competentes y sus supervisados.

\subsection{Organismos Internacionales}

Existen una serie de instituciones que ofrecen servicios que pueden resultar útiles para cualquier investigación de lavado de activos, entre otras podemos citar las siguientes: 


\subsubsection{Comité Interamericano Contra el Abuso de Drogas de la Organización de Estados Americanos (CICAD-OEA)}

- Reglamento Modelo (Base para desarrollar estructuras legales contra el lavado)

- Tipologías de Lavado

- Entrenamientos y Asistencia Técnica

\subsubsection{Grupo de Acción Financiera (GAFI)}

- 40 Recomendaciones Revisadas más 8 Relativas al Financiamiento del Terrorismo

- Elaboración y Aplicación de Metodologías de Evaluación

- Clasificación de Países (Cooperadores/No-Cooperadores, Lista Negra)

- Tipologías de Lavado

- Entrenamientos y Asistencia Técnica

\subsubsection{Grupo de Acción Financiera del Caribe (GAFIC)}

- Aplicación de Evaluaciones

- Tipologías de Lavado (En función de la naturaleza de la región)

- Entrenamiento y Asistencia Técnica

\subsubsection{Grupo Egmont}

La unión de Unidades de Inteligencia Financiera de países de todo el mundo, cuya finalidad es la de generar las sinergias necesarias, vía el intercambio de informaciones y la cooperación.

A través de la Red Segura de Egmont los países miembros cooperan entre sí compartiendo informaciones, en función de lo que sus diversas legislaciones les permiten. Por ejemplo, hay países cuyas legislaciones exigen la firma de un convenio bilateral o memorando de entendimiento con otros estados o territorios y otros que no lo necesitan, tal es el caso de la República Dominicana124.

\subsubsection{Portales Electrónicos de Información}

Para fines de conocer a las personas físicas o jurídicas, en el debido cumplimiento de lo legalmente establecido. Existe una serie de entidades públicas y privadas que ayudan a quienes estén interesados en investigar la veracidad de los datos, que ha ofrecido o de los que simplemente se disponen. Tal es el caso de la Lista OFAC, 
World-Check, entre otros.

\subsubsection{Las Resoluciones emitidas por el Consejo de Seguridad de las Naciones Unidas}

Son muy importantes dado que en algunas se citan nombres de personas físicas o jurídicas vinculadas al terrorismo, con las cuales los países miembros de las Naciones Unidas deben abstenerse de hacer cualquier tipo de negocio y si lo han hecho deben informar al Consejo de los detalles de los mismos.

\subsection{Empresas privadas de informaciones comerciales o de crédito}

Los centros de información crediticia componen una excelente fuente de información, pues a través de los servicios que ofrecen el investigador podrá determinar el posible nivel de pasivos (deudas) que con el sector financiero pueda mantener una persona física o jurídica que esté bajo investigación.

\section{Régimen legal para la administración de los bienes incautados}

La incautación y decomiso de bienes tiene en los procesos por lavado de activos una especial relevancia toda vez que uno de los objetivos de políitica criminal en esta materia lo constituye el privar a los lavadores de los inmensos recursos de todo tipo que estas actividades ilícitas les generan.

De ahí que al ser tan numerosos y diversos los bienes objeto de incautación para fines de posterior decomiso en procesos de esta naturaleza se hace necesario que se adopten mecanismos que preserven el valor de estos activos a fin de que posteriormente puedan ser utilizados por el Estado para financiar los esfuerzos destinados a enfrentar estos fenómenos de la criminalidad.

\section{La situación en nuestro país}

La Ley 72-02, en su artículo 58, crea adscrita al Comité Nacional contra el Lavado de Activos, la Oficina de Custodia y Administración de Bienes Incautados y Decomisados, disponiendo que "tendrá por objeto esencial la custodia, administración y venta de los bienes incautados y decomisados con motivo de la comisión de cualquiera de las infracciones definidas en esta ley. Estará igualmente facultada para contratar con empresas privadas, nacionales o extranjeras, la administración de las propiedades incautadas. El Poder Ejecutivo, al dictar el reglamento para el funcionamiento de esta oficina, incluirá el procedimiento para la venta en pública subasta en los casos previstos en el artículo 14 de esta ley"

Estas disposiciones de la Ley sobre Lavado de Activos se encuentran complementadas por el Decreto No. 19- 
03, de fecha 14 de enero del año 2003, relativo al procedimiento que debe seguir la Oficina de Custodia y Administración de bienes Incautados y Decomisados para el cumplimiento de las responsabilidades puestas a su cargo, en especial lo relativo a qué debe entenderse por bienes que puedan perecer, depreciarse o sujetos a deterioro ; la explotación de fincas ganaderas y agrícolas incautadas así como el procedimiento para la subasta pública de los semovientes y bienes muebles

Por otra parte, cuando los bienes incautados consistan en fondos inmovilizados en manos de entidades del sector financiero, Ios párrafos I y II del Art. 10, de la Ley 72-02, disponen que en los 30 días siguientes a la inmovilización los fondos serán transferidos a una cuenta especial de ahorros en el mismo banco a nombre de la Oficina de Custodia y Administración de bienes Incautados y Decomisados y, conjuntamente con los intereses que aquella genere, quedarán inmovilizados hasta tanto intervenga una sentencia con la autoridad de la cosa irrevocablemente juzgada.

\section{Sugerencias para el desarrollo estratégico de la investigación de lavado de activos}

El problema de la regulación jurídico-penal del "blanqueo de capitales" o "lavado de dinero" plantea, desde el punto de vista políitico-criminal, la necesidad de evaluar las reales posibilidades del sistema procesal penal para procurar una investigación eficiente.

En primer lugar, debe decirse que gran parte de la consolidación definitiva del Ministerio Público Fiscal y de la eficiencia en el control de las conductas aquí analizadas depende de la creatividad y profundización del sistema de relaciones que genere con las instancias de control administrativo.

La primera reacción, vinculada con este punto de partida, debe remarcar una advertencia: el fortalecimiento institucional de todos los organismos de control (judiciales y administrativos) dependen del establecimiento de una red de apoyo mutuo.

Es indudable que, a diferencia de los organismos que ejercen el poder, los que controlan la legitimidad de ese poder no tienen incorporada ya en la pila bautismal su propia vitalidad, sino que requieren llevar como una preocupación fundacional las reales posibilidades de desarrollar cierta capacidad de gestión.

En este sentido, estas instancias de control deben potenciarse en la implementación de un modelo de trabajo de red institucional que asegure, más allá de las eventuales y muchas veces declarativas autonomías de cada organismo, la vitalidad institucional suficiente como para enfrentarse con éxito a la creciente ilegitimidad del poder. 
La multiplicación asistemática de las figuras y mecanismos de control puede ser el modo del tercer milenio de no controlar en forma eficiente, pero sí asegurarse un discurso burocrático aparentemente preocupado por la ética pública.

Ello, por supuesto, encuentra un nuevo justificativo en la optimización de los esfuerzos de investigación. Particularmente, es imprescindible mejorar la utilización de la información que produce cada organismo. En buena cantidad de ocasiones el Estado tiene información valiosa y suficiente sobre eventuales hechos ilícitos, pero sólo produce efectos cuando los diferentes bancos de datos son analizados en conjunto y luego de determinados cruzamientos. Ello en lo que respecta al ilícito de "lavado de activos" es debidamente determinante.

Por otro lado, la relación entre Ministerio Público y los organismos de control administrativo se transforma en una fuente indispensable para la planificación de la política criminal y de persecución penal que debe efectuar el primero.

La política criminal no es otra cosa que una de las más trascendentes políticas de control y, desde este punto de vista, muchas veces debe asumir el rol de "última ratio" o último eslabón en la cadena de reacciones estatales y supeditarse a los objetivos de control de las instancias administrativas, para lo cual debe haber una adecuada coordinación.

Por ejemplo, es claro que si la política de persecución penal del ilícito tributario tiene efectos nocivos en la recaudación ello requiere de modo urgente una solución institucional.

Asimismo, una de las más trascendentes preocupaciones actuales en el diseño orgánico del Ministerio Publico y de su rol procesal reside en la imperiosa necesidad de acercar temporalmente el trabajo de los Fiscales a la producción del caso. En otras palabras, y para decirlo en absoluta claridad, la distancia temporal y burocrática entre la comisión de un ilícito y el ingreso del caso al sistema de gestión del Ministerio Publico es enorme y ello obsta, posiblemente, a un aumento de los índices de éxito en la investigación del sistema penal.

Ello requiere un tratamiento diferenciado según se trate de los denominados por la criminología tradicional "delitos comunes" o de lo que hoy podríamos identificar como delitos complejos, socioeconómicos, delincuencia organizada, etc.

En el primer supuesto, un acercamiento temporal y burocrático entre el fiscal y el caso implicaría un traslado territorial al ámbito comunitario en donde se producen los ilícitos y actúa la instancia policial. 
Ello permite dar pasos sólidos hacia un modelo en el que la actividad policial de investigación se transforme en un verdadero auxiliar del fiscal y no en un organismo con capacidad autónoma de definir su propia estrategia político -criminal, un modelo que permita un aumento de los niveles de especialización de los fiscales sobre la característica de los ilícitos de cada zona territorial, un sistema que favorezca una mejora de los niveles de información sobre el hecho a efecto de perfeccionar las pautas que subyacen en la aplicación de los criterios de oportunidad (si es que se toma la decisión legislativa de abandonar la dañina ficción del principio de legalidad procesal), una estructura orgánica que facilite la selección del camino probatorio en el comienzo del desarrollo procesal del caso impidiendo que el tiempo se transforme en un verdadero obstáculo para la obtención de prueba, y optimizar el tratamiento de los casos con autor desconocido.

Ahora bien, en el segundo supuesto, es decir el de los delitos no tradicionales o complejos, este acercamiento no se vincula con el desplazamiento territorial, si no con una relación cada vez más estrechas entre la actuación fiscal y el desarrollo de los controles administrativos que despliegan los demás organismos.

En muchas ocasiones los hechos que son evaluados por los controles administrativos no son otra cosa que ilícitos de enorme gravedad e impacto social y llegan a conocimiento del Ministerio Publico luego de un tiempo excesivo y la información que se ha obtenido sobre el hecho, a menudo, no es la que se requiere para la formación de la imputación penal.

En este sentido, la eficiencia de la investigación penal preparatoria muchas veces depende de que el Ministerio Público coordine su actuación con el trabajo de las instancias de control administrativo.

Eso mismo hay que trasladarlo a la ley 72-02, que reprime el encubrimiento y lavado de activos de origen ilícito, al generar -más allá de los detalles cuestionables que luego se detallarán- esta instancia de acercamiento con los diferentes organismos de control que pueden ofrecer distintas ópticas y diversos flujos informativos para advertir una "operación sospechosa" o inusual en la terminología de la ley mencionada.

\subsection{El principio de oportunidad}

Hoy día a nadie debería sorprender que, reconocido el derecho del Estado a "expropiar" el conflicto penal de las manos de los protagonistas (autor y víctima "lato sensu"), se afirme la vigencia casi absoluta del deber de los órganos de persecución criminal (Ministerio Público, Juez Instructor), una vez producida la "notitia criminis", de ejercer la acción penal sin ningún tipo de relativización o condicionamientos (principio de legalidad procesal y de oficialidad).

El hecho de que hoy se ponga seriamente y "sanamente" en duda la capacidad o la eficiencia estatal para si 
no "solucionar" al menos "institucionalizar" con un grado de menor violencia el conflicto originario, no significa negar que la idea vigente en nuestro estadio histórico-socio-cultural sea la anterior. La persecución penal "exoficio" y la irretractabilidad de ese ejercicio terminan por dar completa forma a aquella expropiación del conflicto interpersonal.

La vigencia del principio claramente inquisitivo de legalidad procesal ha impedido que las legislaciones procesales o sustanciales regulen la necesidad de cierta relativización por medio de la consideración de algunos criterios de oportunidad.

Sin embargo, hoy no cabe duda que todo el problema del ejercicio de persecución criminal en el proceso está siendo fuertemente replanteado, incluso en sus mismos cimientos. En lo que respecta a nuestra región, el cuestionamiento se inscribe en un proceso total de reforma de los sistemas de enjuiciamiento basados en los parámetros de una Administración de Justicia Medieval.

En particular, los ataques contra la vigencia irrestricta de este principio, según puede observarse, provienen de dos líneas de reflexión, estrictamente vinculadas y quizá superpuestas en algún grado, pero por razones de claridad conviene detenerse en cada una de ellas en forma separada.

Conviene advertir que este pantallazo es ya clásico en el estudio de este tema, por lo cual sólo nos detendremos brevemente, debido a que se intenta proponer alguna corrección del trayecto argumental justificador del principio de oportunidad.

En primer lugar, se destaca el ingreso parcial de cierto utilitarismo, o por lo menos la necesidad de buscar un mayor aprovechamiento de los recursos de la administración de justicia penal.

De la mano de esta reflexión económica se ha advertido el costo, no pocas veces sin sentido, del mantenimiento de este principio sin restricciones.

Hoy no cabe duda que el Estado carece de capacidad de siquiera acercarse a la persecución de todos los delitos cometidos. Pocos casos, en relación al número de sucesos delictivos realmente acaecidos, son los que llegan a conocimiento del Sistema de Administración de Justicia, menos los que superan las etapas previas al proceso penal "stricto sensu" y escasísimos los que llegan a la etapa del Juicio (generalmente no se supera el $10 \%$ de los casos ingresados al proceso penal).

La pretensión del Estado, de "hacer justicia" en todo injusto penal cometido, obligaría al mantenimiento de una estructura policial y de administración de justicia sencillamente descabellada. 
Pero más aún también el efecto social de un Sistema de Administración de Justicia de estas características, si fuera posible, sería absolutamente indeseable.

Sin embargo, esta obligación de naturaleza inquisitiva ha desembocado en un Proceso Penal que, a la manera de una empresa deficiente, es un ejemplo palmario de mala utilización de los recursos del Sistema de Administración de Justicia.

Paradójicamente el Proceso Penal se encuentra abarrotado de casos consistentes en infracciones mínimas y de bajo costo social y es altamente deficiente para resolver los pocos casos que se le presentan en los cuales la infracción significa para la sociedad un costo económico de dimensiones trascendentes. Como ya se ha dicho, conviven un proceso de criminalización intensivo de "bagatelas" y un proceso de descriminalización de hechos delictivos de impacto social inmenso.

La falta de compromiso legislativo con la realidad ha transformado al Sistema Penal, para decirlo con palabras de un conocido jurista alemán (Hans Faller) en "un montón de menudencias".

El principio de legalidad procesal, inmerso no pocas veces en el diseño de una investigación preliminar o procedimiento preparatorio en manos de un Juez instructor (a cargo del sumario), ha impedido que la delincuencia no tradicional, es decir, socio-económica, terrorismo, narcotráfico, corrupción de la función pública, etc., deje de ser un escollo difícil de superar.

Planteado de esta forma el argumento crítico, ya se deja entrever la alternativa de solución. Si se parte de la validez de la comprobación empírica de la incapacidad del Estado de perseguir todos los delitos, es claro que lo razonable reside en que los órganos de persecución estatales posean la libertad jurídica de destinar los recursos hacia las infracciones de mayor gravedad, es decir, permitir un uso inteligente de los escasos recursos. Para ello, es preciso dejar abierta la posibilidad de la consideración de criterios de oportunidad, como modernamente se ha hecho en las legislaciones que lo contienen, relativizando la obligación inquisitiva de poner en marcha el aparato de persecución criminal sin excepciones. Es decir, posibilitar el ingreso legislativo de las razones utilitarias.

En segundo lugar, rige aquí la idea de una congénita selectividad de los sistemas penales. Este es uno de los puntos neurálgicos de la crítica criminológica de los últimos decenios a los sistemas penales.

Sin embargo, aquí es preciso insistir en dos cuestiones particulares. En primer lugar, la advertencia de que esa selectividad no es de ningún modo "inocente". Por el contrario, se encuentra, sin duda, socialmente "orientada". Un simple recorrido de los establecimientos penitenciarios, o un sencillo análisis del comportamiento policial en 
las urbes, demuestra cómo el Sistema Penal es un instrumento que tiende a controlar a los sectores ubicados en las franjas más subordinadas de la estructura social.

Pero mas aún, esa "dirección social" del control penal se encuentra enmarcada en todo el diseño del ejercicio del poder. No cabe duda que el sistema penal cumple una función más que determinante en todo el diseño políitico del Estado.

Y esta selectividad fáctica de los organismos de persecución y represión criminal es un poder paralelo nada despreciable.

En toda esta representación, el principio de legalidad procesal viene a ser un cómplice perfecto de un sistema penal que actúa de este modo. Viene a fundamentar la consolidación de la ficción social, que permite la configuración de la Política Criminal a espaldas del discurso normativo.

Es por ello que en el marco de la investigación de delitos de tanta complejidad como el lavado de activos no hay chances de instalar modelos de investigación eficientes si es que no se permite a los organismos de investigación concentrar sus esfuerzos en los casos de mayor gravedad. 


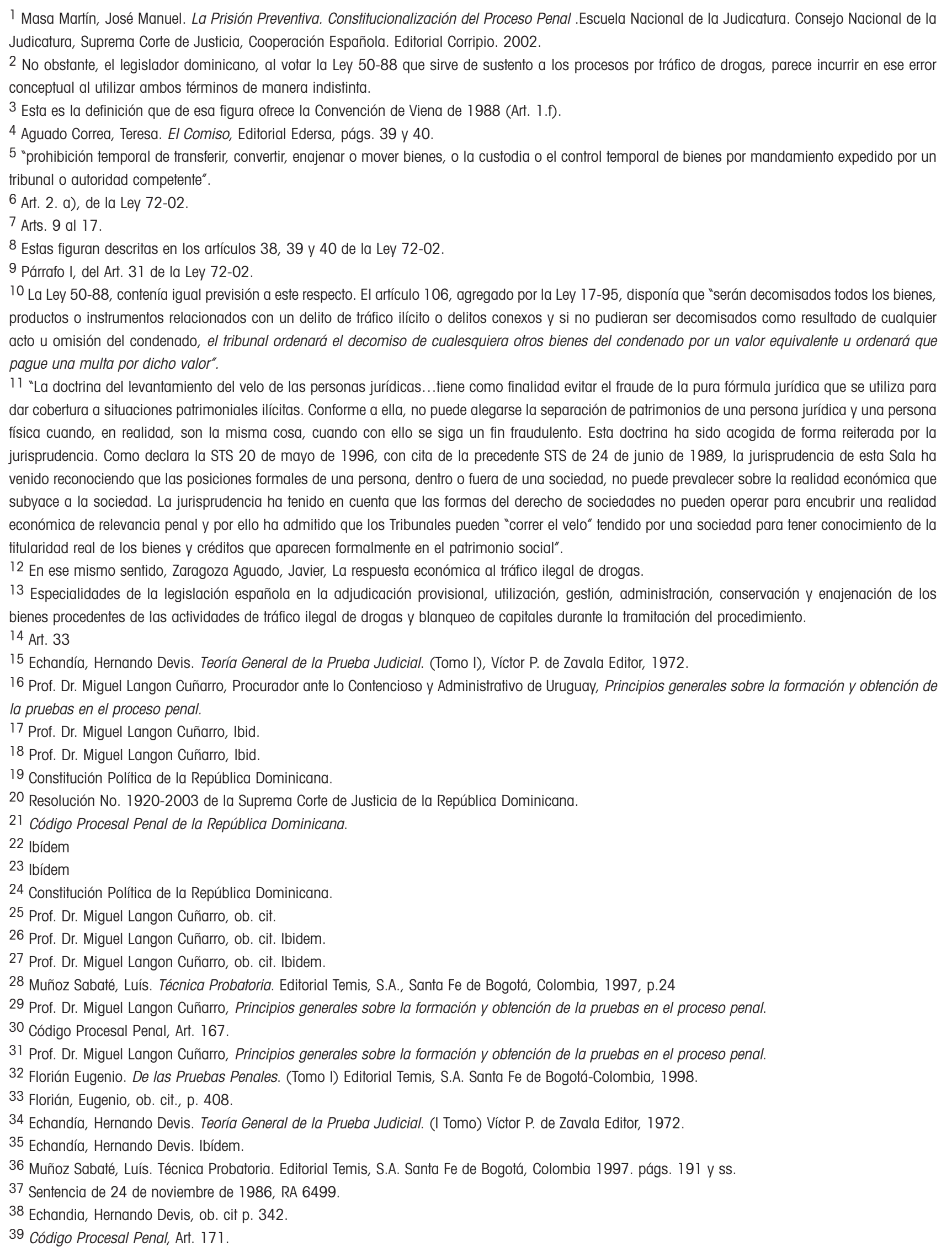


40 Echandia, Hernando Devis, ob. cit., p. 290.

41 Código Procesal Penal, Art. 171

42 Echandia, Hernando Devis, ob. cit., p. 290.

43 Echandía, Hernando Devis, ibídem.

44 Langon Cuñarro, Miguel. Principio General sobre la Formación y Obtención de la Prueba en el Proceso Penal. Procurador Ante lo Contencioso Administrativo, Uruguay.

45 Ley No.72-02, Art. 5.

46 Pinto Dr. Ricardo y Chevalier, Dra. Ophelie, El delito de lavado de activos como delito autónomo. OEA / CICAD, editado y aprobado por el Dr. Rafael Franzini Batlle.

47 Manual de apoyo para la tipificación del delito de lavado. OEA. CICAD.

48 Ley 72-02, Art. 6.

49 Langon Curraño, Dr. Miguel. Principios generales sobre la Formación y Obtención de las Pruebas en el nuevo proceso penal.

50 Curraño, Ibídem.

51 Curraño, Ibídem.

52 OEA/CICAD: Manual de Apoyo por la tipificación del Delito de Lavado.

53 Ferrajoli, Luigi, Derecho y Razón, Editorial Trotta, 4ta. Edición, Madrid, España, 2000.

54 De Asis Roig, Rafael, Jueces y normas, Editorial Marcial Pons, Madrid, 1995 págs. 99-104.

55 Ferrajoli, Luigi, Derecho y Razón, Editorial Trotta, 4ta. Edición, Madrid, España, 2000.

56 Capitán, Vocabulario Jurídico.

57 Florian Eugenio. De las Pruebas Penales. (Tomo II), Editorial Temis, S.A. Santa Fe de Bogotá-Colombia. 1998. p. 351 y ss.

58 Código Procesal Penal, Art. 329.

59 Código Civil, Art. 1322.

60 Código Civil Dominicano, Art. 1318.

61 Código Procesal Penal, Art. 166.

62 Código Civil, Art. 1109.

63 Código Procesal Penal, Art. 166.

64 Código Procesal Penal, Art. 293.

65 Art. 294 del Código Procesal Penal.

66 Art.298 del Código Procesal Penal.

67 Art. 303 del Código Procesal Penal.

68 Echandia, Hernando Devis, Teoría General de la Prueba Judicial, Victor P. Zabalia Editor, Buenos Aires, 1979, p. 534 y ss.

69 Modificación al Código de Procedimiento Civil Dominicano.

70 Echandia, Hernando Devis, ob. cit., p. 534.

71 Código Civil, Art. 1328.

72 Código Civil, Art. 1325.

73 Código Civil, Art. 970.

74 Rincón Cuellar, Hernán. Los Diferentes Medios de Prueba Documental en el Proceso Penal. (Proyecto de Capacitación Judicial Continua. CICAD/OEAPlan Nacional sobre Drogas-Agencia Española de Cooperación Iberoamericana. Tercer Módulo. La Antigua Guatemala, Guatemala, Mayo 21-25, 2001.

75 Muñoz Sabaté, Luís, ob. cit., pág. 294

76 Florián, La Prueba Penal, Editorial Temis, Bogotá. 1967.

77 Código Procesal Penal, Art. 194.

78 Código Procesal Penal, Art. 1 y 194.

79 Código Procesal Penal, Art. 198.

80 Código Procesal Penal, Art. 194.

81 Código Procesal Penal, Art. 196.

82 Código Procesal Penal, Art. 202.

83 Ley No. 136-03.

84 Código Procesal Penal, Art. 198.

85 Código Procesal Penal, Art. 203.

86 Código Procesal Penal, Art. 199.

87 Muñoz Sabaté; Luís. Técnica Probática. Estudio de las dificultades sobre la prueba en el proceso. Editorial Temis, S. A. Santa Fe de Bogotá, Colombia, 1997.

88 Muñoz Sabaté, Luís, ob. cit. pág. 


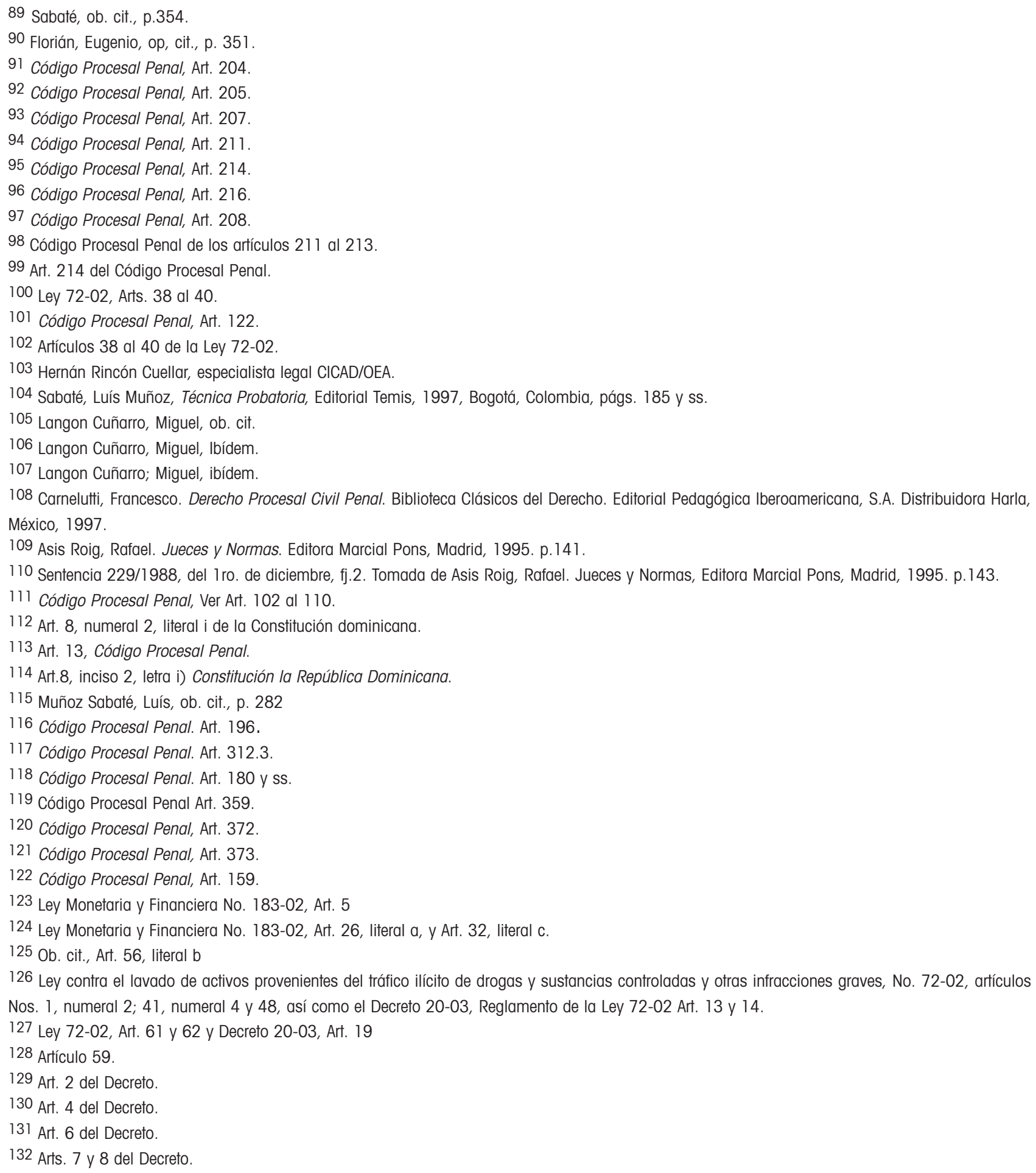




\section{ASISTENCIA JUDICIAL INTERNACIONAL EN EL MARCO DE LA INVESTIGACIÓN Y ENJUICIAMIENTO DEL LAVADO DE ACTIVOS}

Olivo Rodriguez Huertas

\section{Introducción: Ias implicaciones y posibilidades de la asistencia judicial internacional}

Los esfuerzos para enfrentar el lavado de activos serían totalmente inoperantes si, entre otros aspectos, no se contara con mecanismos que permitan una cooperación judicial penal internacional. Ello es la consecuencia directa de la naturaleza transnacional de este fenómeno delictivo: en parte o totalmente, los procesados, los testigos, documentos probatorios, así como los bienes sujetos a decomiso por ser el producto de una actividad ilícita, pueden encontrarse, total o parcialmente, en una jurisdicción distinta a aquella donde se juzga el delito.

De ahí, que, en las últimas décadas, uno de los puntos que figuran en todos los instrumentos normativos internacionales, de alcance universal o regional, así como en las propias declaraciones y recomendaciones formuladas por grupos de trascendencia en la misma esfera, lo constituye lo que tiene que ver con el alcance y la forma en que debe ser prestada la cooperación judicial internacional que se requiere en materia de lavado de activos, entre otros delitos de naturaleza trasnacional.

Javier Zaragoza Aguado', Teniente Fiscal de la Fiscalía Especial Antidroga de España, respecto de este tema señala: "La aparición de mecanismos de cooperación entre los Estados en la lucha contra el crimen hunde sus raíces en pleno siglo XIX. Obviamente, Ias necesidades de cooperación en ese periodo histórico eran mucho mas limitadas y los instrumentos que la definían se circunscribían exclusivamente a la entrega de los delincuentes acusados o condenados por graves delitos mediante la sujeción al procedimiento de extradición. 
La irrupción y el auge de graves formas de delincuencia asociada (terrorismo, narcotráfico y crimen organizado en general) y la transnacionalizacion de sus actividades criminales, han propiciado que la respuesta de los Estados sea, en igual medida, supranacional, y basada en los principios de colaboración y ayuda mutuas. La cooperación internacional entre los Estados en la represión del delito va a ser entendida de manera muy diferente y pasa a sustentarse en principios que restringen objetivamente la soberanía de cada país".

La forma en que se concretiza la Cooperación Judicial Penal Internacional se produce "cuando el aparato judicial de un Estado, que no tiene imperio sino dentro de la porción de territorio jurídico que le pertenece, recurre al auxilio, a la asistencia que le puedan prestar otros Estados, a través de su actividad jurisdiccional".2

La República Dominicana ha suscrito las principales Convenciones Internacionales para combatir la delincuencia organizada a nivel internacional, como lo constituyen las Convenciones de las Naciones Unidas contra el Trafico llícito de Drogas y Sustancias Psicotrópicas (Convención de Viena de 1988), contra la Delincuencia Organizada Transnacional (Convención de Palermo de 2000), y contra la Corrupción (Mérida de 2003). En el ámbito americano suscribió la Convención Interamericana contra la Corrupción auspiciada por la Organización de Estados Americanos (OEA). Solo la primera 3 y la última4 han sido ratificadas por el Congreso Nacional. Por ello constituyen compromisos ineludibles del Estado Dominicano.

Esos instrumentos normativos internacionales tienen en común el hecho de que resaltan la importancia de la asistencia o cooperación judicial internacional en los esfuerzos frente a la criminalidad organizada, por lo que contienen reglas precisas para facilitar su utilización.

Otros instrumentos de igual naturaleza han sido suscritos en el ámbito americano, como la Convención Interamericana sobre Asistencia Mutua en Materia Penal, suscrita en Nassau, Bahamas, el 23 de mayo de 1992, en el marco de la Organización de Estados Americanos. No obstante la República Dominicana aún no ha suscrito la misma por lo que no podría ser utilizada por las autoridades judiciales en la investigación de ilícitos penales de connotación internacional en el ámbito americano.

Sin embargo, nuestro país ha suscrito numerosos acuerdos bilaterales con distintos Estados con los que mantiene relaciones diplomáticas que contienen aspectos relativos a asistencia judicial internacional entre otros delitos, al lavado de activos, y que podrán ser utilizados por las autoridades judiciales para la eficaz persecución de delitos de esa naturaleza juzgables en nuestro país, en la medida en que se hayan dado las condiciones para su entrada en vigencia, según lo prevén los mismos y nuestras disposiciones constitucionales. 


\section{La Convención de Viena de 1988}

La Convención de las Naciones Unidas contra el Trafico llícito de Estupefacientes y Sustancias Psicotrópicas, conocida de forma simplificada como la Convención de Viena de 1988, fue el primer instrumento internacional de alcance universal que otorga primerísima importancia a la cooperación entre los Estados a través de la asistencia judicial para enfrentar un fenómeno delictivo transnacional como el narcotráfico y el lavado de los activos obtenidos con los recursos producidos por tal actividad.

Esta Convención dedica los Art. 7 y 8, a lo relativo a la asistencia judicial recíproca entre los Estados, su alcance y procedimientos. Solo es aplicable a los delitos de lavado de activos provenientes del tráfico de drogas.

\section{Convención de Palermo}

La Convención de las Naciones Unidas contra la Delincuencia Organizada Transnacional del año 2000 contiene, al igual que la Convención de Viena de 1988, disposiciones precisas, aun mas detalladas, para la asistencia judicial internacional.

El Art. 13 de la Convención esta dedicado a la cooperación internacional para fines de decomiso; el Art. 18 a la asistencia judicial reciproca, y el Art. 19 a las investigaciones conjuntas, entre otros aspectos.

Las detalladas técnicas y mecanismos para la cooperación y asistencia judicial previstas en esta Convención aun no pueden ser utilizadas por nuestras autoridades judiciales en la investigación de delitos de lavado de activos generados en actividades ilícitas distintas del narcotráfico, ya que la misma aunque fue suscrita por nuestro país, no ha sido ratificada por el Congreso Nacional.

\section{Convención de Naciones Unidas contra la Corrupción}

Siguiendo la línea de sus antecesoras, las Convenciones de Viena de 1988 y de Palermo del 2000, la Convención de las Naciones Unidas contra la Corrupción, abierta a la firma de los Estados en la ciudad de Mérida, México, en el año 2003, dedica especial importancia a todo lo atinente a la cooperación y asistencia judicial internacional entre los Estados para combatir eficazmente el flagelo de la corrupción a escala planetaria.

La disposiciones que al respecto consagra son más completas y están mejor sistematizadas que las Convenciones anteriores señaladas. En efecto dedica el Capitulo IV a la cooperación internacional (Art. 43 al 49), que tratan sobre extradición, asistencia judicial reciproca, remisión de actuaciones penales, 
investigaciones conjuntas y técnicas especiales de investigación.

Asimismo en otro Capitul05, instituye mecanismos de recuperación de bienes mediante la cooperación internacional, ${ }^{6}$ así como los procedimientos que deben ser adoptados en la cooperación internacional para fines de decomiso de bienes. ${ }^{7}$

A la fecha esta importante Convención no ha entrado en vigencia, y está pendiente en nuestro país la ratificación del Congreso Nacional.

\section{Convención Interamericana contra la Corrupción}

La Convención Interamericana contra la Corrupción constituye un instrumento aplicable en el ámbito americano. Forma parte de nuestro derecho interno toda vez que la misma fue ratificada por el Congreso Nacional, mediante la Resolución numero 489-98.

Los Art. 13, 14, 15 y 16 de la Convención contienen aspectos que pueden ser utilizados en las investigaciones de lavado de activos provenientes de actos de corrupción, en especial lo relativo a la extradición, identificación y rastreo para fines de incautación y/o decomiso de los bienes que son producto de estos actos ilícitos. Asimismo, levantamiento del secreto bancario.

\section{Los Tratados Regionales sobre Asistencia Judicial Internacional}

En el ámbito americano, bajo los auspicios de la Organización de Estados Americanos (OEA), han sido aprobados varios Tratados que tratan el tema de la asistencia judicial internacional8, y que constituyen, para los países que lo han suscrito y ratificado, instrumentos a ser utilizados en procesos de lavado de activos. Entre ellos, podemos señalar los siguientes:

1. Convención Interamericana sobre Recepción de Pruebas en el Extranjero, suscrita en Ciudad de Panamá, Panamá, el 30 de enero de 1975. La misma fue suscrita y ratificada por la República Dominicana.

2. Convención Interamericana sobre Extradición, suscrita en Caracas, Venezuela, el 25 de febrero de 1981. La misma fue suscrita por la República Dominicana, pero aún esta pendiente de ratificación.

3. Convención Interamericana sobre Asistencia Mutua en Materia Penal, suscrita en Nassau, Bahamas, el 23 de mayo de 1992. La misma no ha sido firmada por la República Dominicana. 
4. Convención Interamericana sobre Tráfico Internacional de Menores, suscrita en México, Distrito Federal, el 18 de marzo de 1994. La República Dominicana no ha suscrito dicha Convención.

5. Convención Interamericana contra la Corrupción, firmada en Caracas, Venezuela, el 29 de marzo de 1996. La República Dominicana suscribió y ratificó esta Convención.

6. Convención Interamericana contra la Fabricación y el Tráfico llícito de Armas de Fuego, Municiones, Explosivos y otros Materiales Relacionados, suscrita en Washington, D.C., Estados Unidos de América, el 14 de noviembre de 1997. Dicha Convención no ha sido suscrita por la República Dominicana.

\section{Tratados Bilaterales suscritos por República Dominicana}

La República Dominicana ha suscrito varios Tratados bilaterales con Estados con los que mantenemos relaciones diplomáticas que incluyen el tema de la asistencia judicial internacional en investigaciones del lavado de activos.

Entre ellos podemos citar el suscrito con Colombia, España, Argentina, Francia, México y Cuba.

Asimismo, existe el Convenio suscrito con Centroamérica, en fecha 6 de noviembre de 1997, para la prevención y represión de los delitos de lavado de dinero y activos relacionados con el tráfico ilícito de drogas y delitos conexos. Este Convenio prevé en su Art. 18 la cooperación internacional, sobre todo en lo que tiene que ver con el rastreo y localización de bienes provenientes del tráfico de drogas y delitos conexos, para fines de incautación y/o decomiso.

La cooperación judicial internacional prevista en este Convenio comprende además, otros aspectos como la obtención de testimonios, entrega de citaciones, examen de objetos y lugares, facilitación de información y elementos de pruebas y medidas cautelares, y levantamiento de secreto bancario.

La cooperación internacional en los términos del Convenio suscrito por nuestro país con Centroamérica se hace, a diferencia de lo previsto por los más importantes convenios sobre la materia, a través de la vía diplomática.

\section{Aspectos sobre los que puede recaer la asistencia judicial internacional9}

La asistencia o cooperación judicial internacional penal se efectúa en tres grados:

(a) un primer grado, de simple colaboración, como lo constituyen las diligencias de mero trámite como 
notificaciones, informes o averiguaciones preliminares;

(b) un segundo grado, que incluye medidas que pueden causar un gravamen relevante y en algunos casos irreparables sobre los bienes de las personas como los registros, embargos, secuestros, entrega de objetos, incautaciones y decomisos, y finalmente,

(c) un tercer grado, que comprende las medidas que afectan la libertad y los derechos de una persona, como resultan de un procedimiento de extradición10.

\subsection{Formas de remisión}

Las peticiones de asistencia judicial internacional en los delitos de lavado de activos provenientes del tráfico ilícito de drogas y sustancias psicotrópicas en los términos de la Convención de Viena de 1988, pueden efectuarse de tres formas:

\section{(a) Directamente}

(b) Por la vía diplomática, y

(c) A través de la Organización Internacional de Policía Criminal (INTERPOL), en caso de circunstancias urgentes.

Uno de los grandes aportes de esta Convención en opinión del Fiscal español José Luís Conde Salgado ${ }^{11}$ es que "suprime la vía diplomática como modo normal de transmisión de solicitudes, considerada demasiado

lenta". Ello así "porque la rapidez es un factor esencial en la lucha contra la gran delincuencia... por lo que serán los propios órganos jurisdiccionales los que decidan si van a usar o no la vía directa en los casos en que el Convenio lo permite".

\subsection{Contenido de la solicitud}

Las solicitudes de asistencia judicial internacional requieren de un conjunto de requisitos que figuran enumerados en la Convención de Viena de 1988, que deben ser satisfechos cuando sea requerida en ocasión de procesos de lavado de activos:

(a) La identidad de la autoridad que haga la solicitud;

(b) El objeto y la índole de la investigación, del proceso o de las actuaciones a que se refiera la solicitud, y el nombre y funciones de la autoridad que esté efectuando dicha investigación, dicho procesamiento o dichas actuaciones;

(c) Un resumen de los datos pertinentes, salvo cuando se trate de solicitudes para la presentación de documentos judiciales; 
Una descripción de la asistencia solicitada y pormenores sobre cualquier procedimiento particular que la Parte requirente desee que se aplique;

(e) Cuando sea posible, la identidad y nacionalidad de toda persona involucrada y el lugar en que se encuentre; $y$

La finalidad para la que se solicita la prueba, información o actuación.

\section{El reparto de bienes}

El reparto de bienes es una figura originada en la Convención de Viena de 1988, que procura estimular la cooperación entre los Estados para enfrentar el flagelo del narcotráfico y el lavado de activos provenientes del mismo.

El Art. 5.5.b) ii) de dicha Convención dispone que el Estado que, en virtud de la asistencia judicial internacional haya decomisado bienes, podrá "repartirse con otras Partes, conforme a un criterio preestablecido o definido para cada caso, dicho producto o dichos bienes, o los fondos derivados de la venta de dicho producto o de dichos bienes, con arreglo a lo previsto en su Derecho interno, sus procedimientos administrativos o los acuerdos bilaterales o multilaterales que hayan concertado a este fin".

En términos aún más sencillos, la Convención de Palermo del año 2000, contra la Delincuencia Organizada Transnacional, se refiere a este tema en su Art. 14.3, letra b), disponiendo que cuando un Estado dé curso a una solicitud de decomiso presentada por otro Estado podrán considerar la posibilidad de celebrar acuerdos en el sentido de repartirse "sobre la base de un criterio general o definido para cada caso, ese producto del delito o esos bienes, o de los fondos derivados de la venta de ese producto o de esos bienes, o los fondos derivados de la venta de ese producto o de esos bienes, de conformidad con su derecho interno o sus procedimientos administrativos".

La reciente Convención de Naciones Unidas contra la Corrupción, prevé con términos diferentes la posibilidad del reparto de bienes con motivo de la asistencia judicial internacional en su artículo 57.5 que dispone: "Cuando proceda, los Estados Partes podrán también dar consideración especial a la posibilidad de celebrar acuerdos 0 arreglos mutuamente aceptables, sobre la base de cada caso particular, con miras a la disposición definitiva de los bienes decomisados".

La Ley sobre Lavado de Activos de la República Dominicana contempla esta figura, en el Art. 33, al disponer que "en los casos en que en el proceso de investigación de la infracción hayan participado autoridades de otros países u organismos internacionales, el Estado Dominicano podrá convenir con los demás Estados u organismos internacionales el destino del producto de los bienes decomisados". 


\section{La asistencia judicial internacional prestada por nuestras autoridades judiciales}

Uno de los objetivos esenciales declarados en el Art. 2 de la Ley 72-02, sobre Lavado de Activos, lo constituye lo relativo al marco jurídico a través del cual la autoridad competente de la República Dominicana otorgara asistencia judicial internacional sobre la materia a otros Estados, en virtud de los tratados bilaterales y multilaterales a que está vinculada.

Cónsono con ese objetivo dedica el Capitulo Vl12 a la cooperación internacional, a fin de facilitar al Estado requeriente las diligencias procesales necesarias en materia de pruebas ${ }^{13}$, así como para identificar, detectar, incautar los bienes, productos o instrumentos relacionados con las infracciones de lavado de activos.

El ámbito sobre el que recae la asistencia judicial internacional que en la materia pueden prestar nuestras autoridades son las siguientes:

(a) Recibir testimonios.

(b) Presentar documentos judiciales.

(c) Efectuar inspecciones o incautaciones.

(d) Examinar e inspeccionar objetos y lugares.

(e) Facilitar información y elementos de prueba.

(†) Entregar copias auténticas de documentos y expedientes relacionados con el caso, documentación bancaria, financiera, comercial, social y de otra naturaleza.

(g) Identificar o detectar instrumentos y elementos con fines probatorios, y

(h) Cualquier otra forma de asistencia.

La Ley sobre Lavado de Activos no solo prevé la asistencia judicial para procesos en curso, sino que además hace extensiva la misma para la ejecución de las sentencias dictadas por tribunales extranjeros que ordenen el decomiso de bienes situados en la República Dominicana, exigiendo como requisito la homologación de la misma por un tribunal competente del país.

\section{Exigencias básicas de las cartas rogatorias en el Derecho comparado}

En el ámbito de la cooperación o asistencia judicial internacional se denominan las cartas o comisiones rogatorias como "Ios medios de los que disponen las autoridades judiciales de un Estado para pedir a las de otro Estado que practiquen las diligencias que les encarguen y que son necesarias para las causas penales que 
instruyan". 14

Las cartas rogatorias contentivas de las solicitudes de asistencia judicial internacional en el ámbito penal contienen los aspectos esenciales siguientes: 15

(a) La autoridad judicial que interviene y los datos de identidad de la persona procesada, así como el objeto y la naturaleza del proceso incoado y las normas legales aplicables al caso;

(b) El objeto y motivo de la solicitud de asistencia;

(c) Descripción adecuada de los hechos que constituyen el delito que motiva la asistencia, conforme al derecho interno del país requirente. Deberá transcribirse o adjuntarse el texto de las disposiciones legales pertinentes, debidamente certificados.

(d) Referencia fundamentada a cualquier aspecto o procedimiento especial que el Estado requeriente desea que se adopte.

(e) El plazo dentro del cual el Estado requeriente desearía que la solicitud de asistencia se cumpla.

(†) La descripción del lugar objeto del registro y de los objetos que deben ser aprehendidos.

(g) Mención expresa del tipo de bienes respecto de los cuales se solicita la inmovilización, decomiso, incautación, secuestro y/o embargo, y de su relación con la persona contra quien se inició o iniciará un procedimiento judicial.

(h) Cuando fuere necesario una precisión del monto dinerario a que asciende la afectación de la medida cautelar real.

(i) Las normas y modalidades especiales que eventualmente se requieran para la ejecución de las acciones solicitadas, así como los datos identificatorios de las autoridades del país requeriente o de las partes privadas (actor civil) que puedan participar en ellas.

(j) Cualquier otro dato o información complementarios que sean útiles para la ejecución de la solicitud.

Dos últimos aspectos resultan interesantes respecto del tema: uno, que las cartas rogatorias deben ser redactadas en el idioma del Estado requerido, y el otro, que este último puede solicitar información adicional al Estado requeriente, en caso de ser necesario.

\section{Intercambio de información a través de Unidades de Inteligencia Financiera}

Uno de los aspectos claves para la efectividad de las obligaciones de prevención que le son impuestas a un conjunto de actividades comerciales, empresariales y financieras, susceptibles de ser utilizadas en el proceso 
del lavado de activos, lo constituye la estructuración en cada país de las Unidades de Análisis o Inteligencia Financiera que se encargan de recibir, procesar y analizar los reportes de transacciones financieros sospechosas que le remiten los denominados sujetos obligados.

Dada la naturaleza internacional del lavado de activos, una gran parte de las Unidades de Análisis o Inteligencia Financiera constituyó el Grupo Egmont, en Bélgica, en el año 1995 y posteriormente, en una Reunión Plenaria celebrada en Madrid dos años después adoptó un acuerdo que fomenta el intercambio de información entre dichas Unidades. Los puntos esenciales 16 en los que se apoya su materialización son los siguientes:

(a) se trataría de intercambio de información sobre operaciones financieras sobre las que existan sospechas de estar relacionadas con el lavado de dinero;

(b) la información intercambiada lo sería con fines de análisis e investigación encaminadas a la prevención y/o detección de procesos de lavado de capitales; y

(c) La información intercambiada iría destinada a la Unidad de Análisis o Inteligencia Financiera receptora y no sería revelada a terceras partes ni utilizada para fines diferentes al expresado en el punto anterior, sin el previo consentimiento de la Unidad comunicante.

A los fines de presentar como medio de prueba ante los órganos jurisdiccionales los datos intercambiados entre las Unidades de Análisis o Inteligencia Financiera, deberá formalizarse una solicitud de cooperación judicial internacional.

\section{La experiencia en materia de asistencia judicial internacional en casos que han sucedido en el derecho comparado}

\section{Caso Montesinos}

En el marco de los procesos judiciales seguidos en Perú contra Alberto Fujimori y Vladimiro Montesinos se iniciaron diversas investigaciones vinculadas con posibles hechos de lavado de dinero.

En ese sentido la Fiscalía Anticorrupción, dirigida inicialmente por el Dr. José Ugaz contaba con un equipo especialista en delitos financieros, encabezado por la Dra. Astrid Leigh.

El origen de la colaboración eficaz entre Suiza y Perú radicó en una declaración pública del entonces Ministro de Justicia del Perú, Dr. Belaúnde, que informó sobre la existencia de cuentas bancarias de Vladimiro Montesinos Torres en tres bancos de Suiza. El Gobierno de Suiza dio a conocer que en esas cuentas el ex asesor 
del Servicio de Inteligencia Nacional poseía 48 millones de dólares. Como consecuencia de este hecho la justicia suiza decidió abrir una investigación contra Montesinos por el delito de lavado de dinero en relación a las cuentas abiertas a su nombre en los bancos Bank Leumi de Israel, Fibi Bank de Zurich y el Bank CAI.

Sobre la base de diversos convenios de colaboración eficaz el Gobierno de Perú logró detectar cuentas en el exterior a nombre de Montesinos y /o testaferros por la suma de aproximadamente 436.000.000 de dólares (monto estimado por la Comisión investigadora del Congreso a fines de diciembre de 2002), de los cuales aproximadamente 146.000 .000 habían sido repatriados, 210 bloqueados y 80 restaban por ser bloqueados. 
${ }^{1}$ La Cooperación Judicial y el Blanqueo de Capitales.

2 Raúl Cervini, La Cooperación Penal Internacional, Carlos Álvarez Editor, Valencia 1994, p. 6

3 La Convención de Viena de 1988, fue ratificada por el Congreso Nacional mediante la Resolución No. 7-93 de fecha 30 del mayo de 1993.

4 La Convención Interamericana contra la Corrupción fue ratificada por el Congreso Nacional mediante Resolución de fecha 2 de junio de 1999.

5 Capitulo V

6 Art. 54

7 Art. 55

8 Rincón, Herman, Los Convenios en el Contexto Iberoamericano.

${ }^{9}$ Los datos que son aportados en este número están hechos sobre la base de la Convención de Viena de 1988. En la medida que nuestro país ratifique los demás instrumentos de alcance universal o regional a que se hace referencia en este Capitulo, los mismos deberán ser tomados en cuenta por las autoridades de investigación y persecución del lavado de activos, aunque es bueno advertir que lo contenido en la Convención de Viena es muy semejante a los demás instrumentos normativos internacionales.

10 Víctor Prado Saldarriaga, Las Medidas sobre Bienes en el Contexto de la Cooperación Iberoamericana. Punto 2. En este aspecto se cita al jurista Raúl Cervini en su obra citada.

11 Ponencia "Convención de las Naciones Unidas contra el Tráfico llícito de Estupefacientes y Sustancias Psicotrópicas", Viena, 1988.

12 Art. 61 y siguiente de la Ley.

13 Art. 61 de la Ley.

14 Conde Salgado, José Luís. Convención de las Naciones Unidas contra el Trafico llícito de Estupefacientes y Sustancias Psicotròpicas, Viena, 1988.

15 En este aspecto seguimos al Dr. Víctor Prado Saldarriaga, en su Conferencia "Las Medidas sobre Bienes en el Contexto de la Cooperación Iberoamericana", punto 4.2 .

16 Ponencia "La Cooperación entre Unidades de Inteligencia Financiera" por Alvaro Pinilla Rodríguez. 


\section{LA INVESTIGACIÓN FINANCIERA EN CASOS DE LAVADO DE ACTIVOS \\ Heiromy Castro Milanés}

\section{Introducción}

El mundo delictivo funciona como empresa de tiempo completo. Los criminólogos de antaño dividieron la actividad delictiva en dos grupos:

- Delitos contra personas, tales como asesinatos, robos, entre otros.

- Delitos contra la propiedad, que implica asaltos a residencias, empresas, incendios provocados. En tal sentido, era muy natural describir las actividades delictivas por las víctimas.

Hoy, las actividades delictivas han evolucionado más allá de estas consideraciones, clasificándose por factores de motivación, es decir, por pasión o por ambición.

La avasalladora mayoría de los delitos cometidos son motivados por el dinero. Aquí estriba la importancia de la investigación financiera. En el momento histórico en que vivimos el terrorismo ha recobrado fuerzas, quizás a niveles insospechables, la corrupción dejó de ser un mito en función de que era un fenómeno que sólo se daba en el tercer mundo, siendo muy particular del sector público y el narcotráfico sigue blandiendo sus tentáculos por doquier, produciendo dolor y sus consecuentes crímenes colaterales.

Los sistemas financieros, dada su naturaleza, son blancos de los delitos señalados, pues el dinero generado 0 que se utilice para su financiamiento tenderá a ser movido o convertido al través de éstos.

Ese riesgo inherente que atenta contra el sistema de pagos de cualquier nación implica que las entidades que lo componen generen la conciencia necesaria para conocer de forma objetiva sus amenazas y debilidades. Una vez limitadas las incertidumbres podrán enfocar sus fortalezas hacia el aprovechamiento máximo de sus oportunidades. 
El lavado de activos es usualmente un crimen financiero y por consiguiente un tipo muy particular de fraude, pues tima a la sociedad, al estado de derecho, genera competencia desleal, cataliza la impunidad, puede inducir a que se planifiquen políiticas económicas erradas, con lo que se generarían crisis, caos y aumento en Ios niveles de pobreza. Como suma de todo lo anterior, el lavado atenta contra la gobernabilidad y por ende con el orden democrático de cualquier nación. En tal sentido, lo enfocaremos como un gran fraude y plantearemos su búsqueda en la determinación de pequeños fraudes, que son detonantes de grandes casos.

El trabajo que a continuación se desarrolla está enfocado a proveer instrumentos de investigación financiera de utilidad para el debido cumplimiento de los estándares legales nacionales e internacionales, tanto para Autoridades Competentes como para Sujetos Obligados, en relación a la prevención y detección del lavado de activos.

\section{Principales crímenes gestores del lavado de activos}

\section{1. El Narcotráfico}

Dado su alto nivel de riesgo la venta de narcóticos es muy lucrativa. La estimación del monto total del dinero generado por el narcotráfico es muy difícil de determinar, dado el carácter informal del negocio. Aún así, para finales de la década de los años 90 el Fondo Monetario Internacional (FMI) estimaba que el volumen operado a lavar anualmente oscilaría entre 300 mil y 500 mil millones de dólares norteamericanos. Esto sería, a ese momento, el $2 \%$ al $5 \%$ del Producto Interno Bruto (PIB) global que a su vez, representa aproximadamente el $8 \%$ del comercio internacional.

Para la Organización de las Naciones Unidas (ONU) la cifra sería de 500 mil dólares norteamericanos, al período citado.

La magnitud de esas cifras denota la capacidad de este sector del crimen internacional, pues las mismas equivalen al PIB de varias naciones latinoamericanas.

\subsection{La corrupción}

Definida como la violación de una norma que puede ser legal, ética, moral o el abuso de autoridad, en diferentes niveles, para la consecución de un beneficio personal o corporativo'? 


\subsection{El tráfico de armas}

Otro de los crímenes internacionales que generan excelentes beneficios, que deben ser justificados para que puedan ser disfrutados.

\subsection{El tráfico de seres humanos}

Cuya operación ofrece muy buenos dividendos. Esta práctica de explotación esclavista, y que data de tiempos inmemoriales, lejos de desaparecer ha evolucionado, convirtiéndose en un problema social de dimensiones globales.

\subsection{El financiamiento del terrorismo}

He aquí otro caso muy particular, pues no siempre los recursos con los que se financian las actividades terroristas provienen de la comisión de un crimen, por lo tanto no son recursos mal habidos. Pero, por el hecho de que su destino sea el viabilizar actos terroristas hace que los mismos sean parte de la acción criminal.

La tipificación de "criminal" para el financiamiento del terrorismo debe ser asumida por todos los sistemas legales de los países miembros de la Organización de las Naciones Unidas (ONU), según lo estipula el Convenio Internacional para la Represión del Financiamiento del Terrorismo, así como la Resolución 1373/01, del Consejo de Seguridad de las Naciones Unidas. También es exigido en la Convención Interamericana Contra el Terrorismo de la Organización de Estados Americanos (OEA) y sugerido en las 40 Recomendaciones Revisadas del Grupo de Acción Financiera (GAFI), que sirven de base a todas las legislaciones contra el lavado de activos del mundo y es la médula de la Nueva Metodología de Evaluación del Fondo Monetario Internacional (FMI) y del Banco Mundial (BM).

\section{Investigación del lavado de activos}

Un punto importante a dominar dentro de la cultura investigativa de crímenes financieros y el lavado de activos es la de diferenciar las Unidades de Inteligencia de las Unidades de Investigación.

\subsection{Unidad de Inteligencia Financiera}

Es una estructura que se encarga de solicitar, recibir y difundir a las autoridades competentes, los reportes de información financiera relacionados con las ganancias que se sospecha provienen del crimen que esté establecido en su legislación o en su reglamentación nacional, con el fin de combatir el lavado de activos. 


\subsection{Unidad de Investigación Financiera}

Es una estructura de tipo policial que se encarga de investigar los reportes enviados por la Unidad de Inteligencia y casos producto de denuncias. Además, efectúa requerimientos a la Unidad citada para el acopio de pruebas, investiga vínculos entre sospechosos, crea sus perfiles y les da seguimiento.

En la gestión de ambos roles, bajo la evidencia de sospecha, se deberá acopiar y analizar informaciones al través de:

- Revisión de Documentos: títulos de propiedad, declaraciones de impuestos, constitución de empresas, créditos, inversiones, cuentas corrientes, entre otras, de la persona sospechosa.

- Establecer la identidad de familiares, amigos, empleados, socios y estructurar un organigrama.

- Revisión de documentos de familiares, amigos, empleados, socios y obtener, de cada uno, las mismas informaciones señaladas en el literal a.

- Buscar elementos comunes en la información recopilada, ya sean bancos, tipos de inversiones, tipos de negocios, asesores, entre otros.

- Identificar las personas que administran o tienen cargos de responsabilidad en las instituciones identificadas con patrones comunes o las personas que mantienen vínculos con los allegados al sospechoso.

- Hacer un seguimiento a las operaciones bancarias y financieras, estableciendo enlaces o cadenas y patrones comunes.

- Crear enlaces en las instituciones de supervisión financiera, de valores, de comercio, de divisas, de seguros, de control fiscal, entre otros, con la finalidad de obtener la información que necesite.

- Establecer si el monto de las operaciones ubicadas en las cuentas de cada persona se corresponde con las operaciones ordinarias de los negocios o actividades productivas que han sido declaradas y comparar con la competencia (Ver Casos y Métodos).

- Hacer vigilancia personal y electrónica (si es legal y bajo el procedimiento establecido) de los sospechosos, a fin de establecer vínculos².

- En los allanamientos, buscar libros de registros, contabilidad manual o automatizada, para fines de establecer vínculos entre sus operaciones criminales y las ordinarias.

- Utilizar informantes.

- Entrevistar testigos y colaboradores.

- Mantener enlaces internacionales (INTERPOL, Grupo Egmont, DEA, CICTE-OEA). 
- Hacer el balance contable de los negocios y demostrar con ello, de existir, el incremento injustificado (Ver Casos y Métodos).

- Con el análisis de la información, determinar el conjunto de indicios que permiten establecer los enlaces de las operaciones económicas con la persona vinculada a actividades sospechosas.

\subsection{Indicios}

Son los hechos de los que se infiere de forma lógica la existencia de otros hechos. Se parte de un hecho indicador que debe estar probado, y a partir de ahí se deducirá un hecho indicado que debe ser probado. Como conclusión lógica de la interrelación de ambos hechos se podrá inferir una conclusión que constituye el indicio3.

Por ejemplo:

\section{A}

Hecho indicador: El señor XX presenta un incremento patrimonial de \$YY.

Hecho deducido: El incremento patrimonial no se corresponde con las operaciones ordinarias del negocio y de su competencia.

Conclusión: $\quad$ El incremento patrimonial es injustificado.

\begin{tabular}{|l|l|}
\hline Hecho indicador: & $\begin{array}{l}\text { Las personas que presentan este incremento patrimonial } \\
\text { mantienen vínculos de parentescos, amistad o de negocios con el } \\
\text { señor ZZ, a quien se relaciona con actividades ilícitas. }\end{array}$ \\
\hline Hecho deducido: & $\begin{array}{l}\text { Estas personas conocían de la comisión de las actividades } \\
\text { ilícitas. }\end{array}$ \\
Conclusión: & $\begin{array}{l}\text { Estas personas conocen o deben conocer que el dinero del señor } \\
\text { ZZ tiene un origen ilícito. }\end{array}$ \\
\hline
\end{tabular}




\begin{tabular}{|l|l|}
\hline Hecho indicador: & $\begin{array}{l}\text { El incremento patrimonial injustificado del señor XX se inició } \\
\text { cuando se establecieron los vínculos con el señor ZZ.. }\end{array}$ \\
Hecho deducido: & $\begin{array}{l}\text { El señor XX y el señor ZZ mantienen relaciones de orden } \\
\text { económico. }\end{array}$ \\
Conclusión: & $\begin{array}{l}\text { El incremento patrimonial del señor XX deriva del dinero del señor } \\
Z Z .\end{array}$ \\
\hline
\end{tabular}

\begin{tabular}{|l|l|}
\hline Hecho indicador: & $\begin{array}{l}\text { Las explicaciones dadas por el señor XX sobre sus actividades no } \\
\text { justifican el monto del incremento patrimonial. (Fondos } \\
\text { procedentes de fuentes desconocidas. Ver Métodos) }\end{array}$ \\
\hline Hecho deducido: & El señor XX mintió con respecto a su incremento patrimonial. \\
\hline Conclusión: & Al señor XX lo han incriminado sus falsas declaraciones. \\
\hline
\end{tabular}

En este punto hay suficientes indicios para fines de un procesamiento judicial.

\section{Sistemas de transacción ${ }^{4}$}

Toda transacción económica se efectuará al través de los sistemas siguientes:

\subsection{En efectivo}

Se da cuando todas las transacciones se efectúan en efectivo. Las transacciones ilícitas, usualmente son cursadas en efectivo.

\subsubsection{Ventajas}

- Cualquier persona puede pagar con efectivo los bienes ilegales o legales, dando paso a una de las fases del lavado.

- La falta de registros dificulta la conexión de una persona con actitudes delictivas o con la compra de bienes ilícitos. 
- No se gravan los ingresos no registrados.

- El dinero en efectivo es utilizado universalmente.

\subsubsection{Desventajas}

- En grandes cantidades, el efectivo genera sospechas.

- La falta de registros implica debilidad en el control interno.

- Las grandes cantidades de efectivo son difíciles de manejar, de transportar e implican mayores riesgos.

- Existen activos cuya adquisición en efectivo se dificulta, dado su volumen.

\subsection{De Negocios}

Es en el que todas las operaciones se efectúan a través de documentos, que pueden ser cuasi-efectivo. Los avales generan registros financieros. Estos últimos resumen la actividad financiera reflejando fuentes específicas, destinos participantes y fechas.

\subsubsection{Ventajas}

- Existe mayor eficiencia y seguridad en la operatividad comercial y financiera.

- Las pérdidas por concepto de robos estarían sujetas a un mejor control.

- Ofrece un abanico más amplio de oportunidades para fines de inversiones legítimas.

- Un negocio legítimo es una base valiosa de operaciones.

- Un negocio legítimo permite la adquisición de una posición dentro de la sociedad, el cual puede proporcionar un disfraz adicional para operaciones ilícitas.

\subsubsection{Desventajas}

- Deben pagarse impuestos.

- Los registros están sujetos a exámenes por parte de las autoridades.

- La falsificación de registros es un acto delictivo que al ser descubierto puede generar la apertura de un caso que conduzca a la realidad de los hechos.

- Las transacciones tienen una fuente de origen o de destino, lo que ayudará al investigador a seguir el dinero.

Seguir el dinero, es la ley procedimental de todo investigador financiero. 


\section{Métodos de lavado de activos}

Existe una cantidad muy diversa de métodos que son utilizados para cosmetizar el origen ilícito de activos, y que pueden ir desde un simple canje de divisas hasta una sofisticada ingeniería financiera. A continuación, podrá apreciarse cómo se utilizan diferentes negocios, áreas y/o territorios, para los fines citados.

Se puede lavar activos al través de:

\subsection{Negocios Legítimos}

Éstas son entidades ideales para efectuar actividades de lavado, dada la fachada que ofrecen para mezclar activos lícitos con ilícitos. Por ejemplo, aquí un lavador podría hacer lo siguiente:

- Exagerar los ingresos legítimos.

- Exagerar los gastos legítimos.

- Utilizar los depósitos en efectivo.

A continuación veamos sus aplicaciones prácticas en el Caso "Zoom Videos"

\section{Caso Zoom Videos}

Veamos cómo la empresa Zoom Videos mueve dinero entre el Sistema de Efectivo y el Sistema de Transacción de Negocios. También introduciremos algunas estrategias de investigación que pueden utilizarse para detectar lavado de dinero.

Zoom Videos se localiza en un pequeño centro comercial metropolitano. Basa su actividad de negocios en la venta de discos compactos, cintas y la renta de videocintas. El propietario John Doe, un traficante local de narcóticos, trabaja tiempo parcial en la tienda y tiene cuatro empleados de tiempo completo que no están enterados de sus actividades de narcotráfico. La esposa de Doe, que sí está enterada de estas actividades ilegales, lleva los libros y registros del negocio. A los clientes se les solicita que paguen preferiblemente en efectivo por sus compras y, cuando lo hacen así, reciben un descuento del $15 \%$.

\section{Exageración de Ingresos Legítimos}

Con este método de lavado de dinero se agregan productos ilegales a los registros de ventas de un negocio legítimo. El Sr. Doe, utiliza este esquema en Zoom Videos haciendo las tres cosas siguientes: 
- Falsificación de facturas (reducción del valor de las facturas). Lee hace que su personal computarice el descuento del 15\% sobre compras en el renglón de mercancía salida, pero los hace que muestren el precio total en la factura de venta "para fines de la contabilidad". Para el año 2002, las ventas legítimas en efectivo totalizan la cantidad de $\$ 300,000$. El 15\% de descuento por pago en efectivo redujo los recibos reales de efectivo en $\$ 45,000$ lo que significó que los recibos netos en efectivo ascendieron a $\$ 255,000$. Ahora el Sr. Doe puede depositar $\$ 45,000$ de ganancias derivadas de la droga en la cuenta bancaria del negocio para reemplazar la reducción del descuento.

- Generación de facturas falsas. El Sr. Doe generó facturas por ventas falsas y facturas por rentas de video por un total de $\$ 65,000$ y $\$ 32,000$ respectivamente. La creación de ventas ficticias involucra un poco más de riesgo porque requiere la fabricación completa de todos los elementos de una venta, que es menos que modificar parte de una venta normal. Pero, aparentemente, valía la pena correr el riesgo. Pues así podría depositar una cantidad adicional de $\$ 97,000$ de ganancias del narcotráfico.

- Exageración (inflación) del costo de los bienes vendidos. En el 2002 el costo real de bienes vendidos fue de $\$ 260,000$. El Sr. Doe infló (exageró) esta cantidad por \$28,000, copiando y después alterando las facturas de compras.

El Estado de Ingresos de Zoom Videos al 31 de diciembre del 2002 muestra el efecto causado por el dinero de las actividades de lavado del Sr. Doe sobre su negocio. El resultado de las actividades antes descritas puede verse en la cifra de Ingreso Bruto (Gross Income).

La exageración del ingreso declarado tiene una desventaja de importancia y es que el ingreso adicional está declarado abiertamente, por lo que la cantidad es gravable. A menos que los delincuentes financieros quieran pagar una gran porción de sus ganancias lavadas en impuestos, necesitaran encontrar una forma de reducir su incrementada obligación de impuestos. La forma como resuelven este problema es exagerando sus gastos legítimos de negocios.

\section{Exageración (inflación) de gastos legítimos}

El exagerar los gastos de negocios complementa la exageración de los ingresos. Debido a los gastos inflados, como los gastos actuales son deducibles de impuestos, la obligación adicional de impuestos causada por los ingresos inflados puede reducirse o quedar eliminada. Las posibilidades de exagerar los gastos quedan limitadas únicamente por la imaginación. Las cantidades que pueden ser "pagadas" por concepto de suministros o bienes jamás recibidos, consultores ficticios que "reciben" honorarios, empleados inexistentes a los que se les "paga" regularmente, la depreciación, entre otros, son cosas que pueden reclamarse sobre activos inflados o inexistentes.

Al revisar el Estado de Ingreso, al 31 de diciembre del 2002, puede apreciarse que el Sr. Doe infló los gastos 
de su negocio legítimo en 2002 por \$62,000. Agregó dos de sus distribuidores de narcóticos a su libro mayor de nómina e incrementó sus gastos anuales de sueldos por $\$ 48,000$. Al retener impuestos y expedir estados de sueldos y salarios anuales, les ha dado a sus distribuidores una fuente aparente de ingresos legítimos. A través del año, exageró el pago a proveedores por \$4,000 y después depositó sus cheques de reembolso a la cuenta bancaria del negocio como ingreso adicional por ventas. La cantidad original pagada al proveedor se registra como gasto y el cheque cancelado se utiliza como comprobación del gasto.

Un honorario por consultoría de $\$ 10,000$ se muestra como gasto. Esto podría ser totalmente ficticio. Tal vez el Sr. Doe pagó $\$ 10,000$ a un socio del narcotráfico en sus actividades ilegales, o tal vez utilizó el dinero para comprar bienes personales, o un bien personal.

El Sr. Doe manipuló las actividades financieras de su negocio exagerando tanto los ingresos como los gastos. No todos los lavadores de dinero utilizan los dos métodos juntos. Algunos utilizan solamente uno o el otro. Un traficante de drogas que desea generar una cantidad sustancial de ingreso para justificar un estilo de vida de derroche, puede únicamente exagerar sus ingresos. Por otra parte, un lavador de dinero que espera evadir impuestos, inflaría únicamente los gastos.

\section{Depósitos en Efectivo}

La tercera forma en que a través de un negocio legítimo se puede lavar dinero es depositando productos en efectivo generados por una actividad ilegal en las cuentas bancarias del negocio, sin ocultar los depósitos como recibos normales de los negocios operados.

Este método no puede resistir el escrutinio de un investigador porque cualquier cantidad de efectivo que va a un negocio debe provenir de algún lugar: de ingresos por ventas de bienes, de préstamos o inversiones por parte de los propietarios.

El método de depósitos en efectivo se utiliza principalmente para tomar ventaja de las cuentas bancarias del negocio y así transferir ganancias ilegales hacia el sistema de transacción de negocios.

Pueden expedirse cheques sobre las cuentas del negocio para gastos personales de manutención y comprar activos personales, etc., por lo tanto, se evita el que se generen sospechas que de otra forma surgirán si se tratara de grandes cantidades de efectivo. 


\section{Empresas Ideales para el Lavado de Dinero 5}

Como ha podido apreciarse en el ejemplo de Zoom Videos, el uso de empresas legítimas como mecanismo para ocultar y entremezclar dinero ilícito dentro de una operación incluye procedimientos contables de nivelación. El dinero ilegal es raramente mezclado físicamente con los recibos legítimos del negocio, más bien, los registros contables se falsifican para atribuir más ingresos o más gastos a la empresa e indirectamente a los propietarios de lo que en realidad se ganó o se gastó.

Idealmente, un establecimiento óptimo a través del cual se faciliten operaciones para lavar dinero sería uno que:

- Trate principalmente con efectivo

- Tenga costos fijos relativos

- Esté exento de reportar el efectivo depositado a las autoridades.

Tradicionalmente, los bares, restaurantes, cines, teatros y salones de masajes han sido utilizados como medio de operaciones en esquemas de lavado de dinero. Estos tipos de operaciones de negocios proporcionan una pronta ubicación para ventas ilícitas y reuniones clandestinas. Dependiendo del talento administrativo y de las personas involucradas, casi cualquier actividad de negocios puede utilizarse para el lavado de dinero. Sin embargo, los negocios que son altamente competitivos o requieren capacidades técnicas substanciales son menos atractivos para las actividades delictivas. La explicación de esto estriba en que es difícil administrar ambos a un mismo tiempo: un negocio que exige mucha dedicación y una organización delictiva, que exige también dedicación extrema.

Puede utilizarse un indicador independiente para desarrollar pistas financieras cuando se sospecha existe lavado de dinero. Por ejemplo, si Zoom Videos tenía un inventario de 400 videocintas y la cuota de renta era de $\$ 2.00$ al día, entonces el ingreso mensual no debería exceder de $\$ 24,000$ (400 x $\$ 2.00 \times 30$ ). Si la tienda reporta recibos brutos de $\$ 35,000$ mensuales, el investigador debe deducir que $\$ 11,000$ proceden de otra parte.

Mientras que pequeñas variantes no constituyen una prueba de fraude adecuada, el fraude a gran escala difícilmente soporte este tipo de análisis.

La validez de ciertos tipos de gastos puede determinarse a través del uso de indicadores independientes. Por ejemplo, la compra de gasolina reportada (un gasto de negocios) en cantidades que son suficientes para mantener un camión de servicio en operación durante las 24 horas del día todo el año, sería evidentemente sospechoso. La evidencia de empleados ficticios puede ser verificada independientemente por fuentes de 
información que no son la nómina tarjetas de reloj tomador de tiempo, registros del sindicato, pagos de compensación a desempleados, registros de retención de impuesto, entre otros. Lo encontrado durante las investigaciones que revele que ciertas ventas no tuvieron lugar jamás, o empleados en nómina que no existieron nunca, o inventario reportado con artículos falsos, proporcionaría indicación significativa de una operación de lavado de dinero.

Para el investigador financiero, la detección del lavado de dinero depende muchísimo de la calidad de la documentación. Usando indicadores independientes para probar la validez del ingreso reportado y de los gastos puede determinarse el grado de variación de las verdaderas actividades relacionadas con el negocio.

\section{ZOOM VIDEOS}

\section{Estado de Ingresos al 31 de diciembre del 2002}

\begin{tabular}{lcc}
\hline Ventas & Sin lavado de dinero & Con lavado de dinero \\
\hline Caja & $\$ 255,000$ & $\$ 365,000$ \\
\hline Cheques & 120,000 & 120,000 \\
\hline Rentas de Videos & 52,000 & 84,000 \\
\hline Total Ventas & 427,000 & 569,000 \\
\hline Costo de mercancía vendida & 260,000 & 569,000 \\
\hline Ingreso bruto & 167,000 & 281,000 \\
\hline Gastos & Sin lavado de dinero & Con lavado de dinero \\
\hline Sueldos y Salarios & 96,000 & 144,000 \\
\hline Suministros & 6,000 & 10,000 \\
\hline Renta & 36,000 & 36,000 \\
\hline Gastos de interés & 12,000 & 12,000 \\
\hline Teléfono & 9,000 & 9,000 \\
\hline Honorarios Consultores & 0 & 0 \\
\hline Total de Gastos & $\$ 159,000$ & $\$ 211,000$ \\
\hline Ingreso Neto & 8,000 & 70,000 \\
\hline
\end{tabular}




\subsection{Negocios llegítimos}

Son negocios ilícitos o no registrados, generadores de dinero sucio, compañías fantasmas (Que se dice que existen pero no son reales), que usualmente necesitan una mayor complementariedad por parte de otras áreas para lograr legitimar fondos o asumen un mayor riesgo.

Dada su ilegitimidad, usualmente, los controles operativos no se registran o son a su vez irreales.

\subsection{Transacciones de compra y venta}

Por medio de este tipo de transacciones pueden manipularse las operaciones para ocultar el flujo de productos ilegales y dar apariencia lícita a los mismos.

La utilización de vinculados que adquieren bienes y luego venden a otros vinculados, generando una suerte de mercado secundario dentro de un grupo de personas que se compran y venden bienes. La realidad es que el dinero que fluye, tiene una procedencia ilícita y a través de las ventas y adquisiciones se legitimaría, pues después de una operación el vendedor podrá justificar su procedencia. Debemos apuntar que para un Gerente de Cumplimiento acucioso, aquella sería una operación inusual, que con una simple investigación de vinculados y conducta financiera se convertiría en una operación sospechosa. Es decir, con la simple aplicación de una políitica racional de "conozca su cliente".

Supóngase que alguien esté comprando una finca cuyo valor real es de \$3 millones. El comprador acuerda con el vendedor que pagará \$1 millón por la finca y que el resto se lo pagará fuera de libros (en efectivo, drogas, otros). Aquí la transferencia del sistema de transacciones en efectivo hacia el sistema de transacciones del negocio se ha logrado y ha tenido lugar una operación de lavado de dinero.

\subsection{Paraísos Fiscales}

Ya se ha apuntado la importancia que tiene para el investigador seguir el dinero. Si el dinero toca un país que ofrece un clima económico y legal adecuado para ocultar la procedencia de los fondos, la investigación puede tender al fracaso.

Un Paraíso Fiscal es el país o territorio que ofrezca los atractivos y características siguientes:

- Inviolabilidad del secreto bancario.

- Cuentas cifradas y anónimas. 
- Se requiere de poca o ninguna identificación para efectuar operaciones.

- Uso de instrumentos monetarios pagaderos al portador.

- No existe monitoreo de efectivo al entrar y salir del país.

- Reglamentos laxos y sistemas financieros no bancarios, muy bien establecidos.

- Tipificación limitada o inexistente del lavado como crimen.

- No hay requerimientos sobre las instituciones financieras de que registren las transacciones importantes en efectivo, ni de que informen sobre transacciones sospechosas.

- Limitada capacidad gubernamental para confiscar bienes.

- Aceptación de transacciones en cualquier tipo de moneda.

- Limitados controles bancarios y monetarios

- Alto volumen de transferencias interbancarias de efectivo e instrumentos monetarios.

- Gran parte de las transacciones se inician fuera del país o territorio que es un paraíso fiscal.

- La mayoría de las entidades financieras son controladas por no residentes.

- Posibilidad de establecer sociedades de fundación instantánea.

- Excelente plataforma electrónica.

- Ubicación geográfica que facilite los viajes de negocios de ida y vuelta, desde países vecinos ricos.

Es de rigor establecer la diferencia entre un Paraíso Fiscal y un Centro Financiero Internacional. Usualmente, todos los Paraísos Fiscales son, por las ventajas que ofrecen, Paraísos Financieros. Pero no necesariamente éstos últimos son Paraísos Fiscales, tal es el caso de Panamá y Singapur. Estos países cuentan con un sistema financiero enorme, más no guardan las características anteriores, salvo las relativas a servicios electrónicos, ubicación geográfica y uso de cualquier moneda fuerte en sus transacciones.

\subsubsection{Clasificación6}

En estos paraísos es donde se establecen la mayor parte de entidades Off-Shore (extraterrritorial, fuera de orillas), debido a sus características. Los centros Off-Shore pueden clasificarse como:

- Centros Off-Shore Primarios, que son los que cuentan con sistemas de pagos avanzados y cuyos mercados cuentan con excelente liquidez. Estos se manifiestan en países desarrollados.

- Centros Off-Shore Secundarios, que tienen un sistema de pagos adecuado, pero requieren de otros mercados para obtener liquidez. Por ejemplo: Hong Kong, Singapur, Panamá, Luxemburgo, entre otros. 
Centros Off-Shore de Registro, que cuentan con entidades que pueden ser intermediarias y otras que simplemente funcionan como libros de registros, cuyas transacciones se concentran en otras jurisdicciones, pero se cruzan donde opera la entidad. Por ejemplo, los Paraísos Fiscales.

\subsubsection{Métodos para movilizar dinero fuera o hacia un paraíso fiscal7}

- Transporte Físico: cuando el dinero obtenido de forma ilegal es transportado físicamente desde un país hacia un Paraíso Fiscal en portafolios, equipaje, en personas que sirven de mulas, entre otros.

- Transferencia Cablegráfica: cuando una suma es depositada en una entidad bancaria de un país, usualmente un monto menor al requerido para fines de registro, y luego ese dinero es enviado mediante transferencia cablegráfica a una cuenta bancaria de una entidad financiera establecida en el Paraíso Fiscal.

- Cheque de Caja/Gerencia/Administración: se deposita como se ha apuntado antes y se solicita un cheque de gerencia, el que a su vez es enviado por correo o transportado físicamente al extranjero.

- Precios de Importación/Exportación: al registrar costos incorrectos en facturas de importación/exportación por concepto de productos enviados o recibidos. (Ver ejemplos en anexos)

- Administradores, Contadores y Administradores de dinero: ellos se les da el dinero que depositarían en una cuenta de fideicomiso. Esta es una cuenta bancaria mantenida por y bajo custodia de esta parte, que utiliza para fondos relativos a los intereses financieros y/o negocios del cliente. Los fondos pueden ser transferidos, a través de cablegrafía o cheques de caja, gerencia o administración, al extranjero.

- Cuentas de Corretaje: donde se depositan los cheques de cajas, de gerencia o de administración, de negocios ficticios o cheques personales. Los retiros subsecuentes se envían por correo o se trasportan físicamente al extranjero.

- Agentes de Cambio Remesadores (Servicios de Transferencias): las empresas que ofrecen este servicio pueden ser utilizadas para transferir fondos hacia los Paraísos Fiscales.

- Préstamos Ficticios: cuando una empresa ficticia establece una cuenta en un país extranjero y a través de éstas reciben préstamos de compañías cuya real operación se dificulta establecer.

- Inversionistas Extranjeros Ficticios: cuando se forma un negocio legítimo en un país, pero se utilizan "inversionistas ficticios extranjeros" que proporcionarían capitales a la empresa. Los pagos del sistema de transacción de negocios (cheques de Caja, de Gerencia o de Administración, transferencias cablegráficas y cheques de negocios, de negocio o de individuos ficticios) fluyen retrospectivamente hacia el país.

- Honorarios por Localización: cuando se generan honorarios por localización o pagos por servicios prestados. Estas transacciones falsas pueden ser para localizar inversionistas para negocios extranjeros, para negociar compro de bienes raíces, entre otros. 
Sueldos Corporativos: son los pagados por una empresa ficticia extranjera por medio de cheques corporativos, transferencias cablegráficas o cheques de caja, de gerencia o de administración.

Una vez los fondos se encuentran en una cuenta de un Paraíso Fiscal, puede hacerse una transferencia electrónica hacia una cuenta bancaria que bajo un nombre falso se aperture en otro Paraíso Fiscal, por una empresa que controla esa cuenta en ese último país o territorio. Desde aquí se hace "préstamo" a una empresa ficticia en un país cualquiera, que es controlada por un delincuente financiero, quien de hecho originó estos productos ilegales. Los problemas surgen cuando el proceso del lavado implica una jurisdicción extranjera, del tipo Paraíso Fiscal. La clave para detectar y resolver este tipo de operaciones es documentar el flujo de dinero con anterioridad a su salida del país, pues la mayor vulnerabilidad del crimen del lavado se manifiesta en su primera fase, es decir, en la colocación.

\subsection{Sistemas financieros y cambiarios}

El producto de intercambio de estos sistemas es el dinero, de aquí el atractivo que manifiestan estos sectores.

Es entendible que cualquier funcionario pueda ser engañado, pues los delincuentes no guardan reglas, por lo que siempre mantienen muchos pasos delante de las autoridades y de los programas de seguridad de las entidades financieras o cambiarias.

Por otro lado, el lavado puede darse por negligencia, por no completar la debida diligencia, dejándose utilizar por los lavadores. También, puede darse cuando las operaciones de lavado se efectúan a sabiendas.

Para fines de que no se alegue ignorancia existe muy buena literatura que indica la calidad inusualidad 0 sospecha de una operación financiera8.

\section{Cómo rastrear el movimiento del dinero en una negociación}

La contabilidad es el lenguaje de los negocios. A través de ésta nos informamos, clasificamos y resumimos los efectos de las transacciones financieras.

Para fines de análisis asumiremos una empresa, pues usualmente ésta debe mantener registros financieros más acabados que las personas físicas. 


\section{1. Composición, definición y naturaleza de los Estados Financieros}

Por considerarlo de rigor, para su correcto manejo e interpretación, a continuación explicaremos la estructura de un Estado Financiero, a saber:

\subsubsection{Activos}

Es el conjunto de todos los bienes, valores, propiedades y derechos de una persona física o moral.

- Activos Corrientes, compuesto por el efectivo y otras partidas que pueden convertirse en efectivo en el corto plazo.

- Activos Fijos, que son las propiedades de naturaleza relativamente permanente y que se emplean en las operaciones de los negocios. A su vez, éstos pueden ser tangibles (edificios, terrenos, equipos) o intangibles (patentes, franquicias, entre otras).

\subsubsection{Pasivos}

Que están constituidos por el conjunto de deudas u obligaciones pecuniarias. Al igual que los Activos se dividen en Corrientes y Fijos.

\subsubsection{Capital}

De la diferencia entre Activos menos Pasivos, se obtiene el Capital o patrimonio, que está constituido por aquella parte del activo que se encuentra libre de obligaciones.

\subsection{Análisis de posicionamiento9}

En la actualidad existen muchos tipos de análisis que son de gran utilidad para determinar el posicionamiento financiero de una empresa. Con esta determinación pueden ser comparados los valores obtenidos con el llamado Índice Promedio Industrial, que no es más que la media óptima del sector a la que pertenece la empresa investigada. De no existir podría determinarse con un promedio de una muestra real de la capacidad instalada en operación. Esto para economías con niveles de transparencias inadecuados.

Para determinar el posicionamiento de una empresa, los tipos de análisis más utilizados en la actualidad son Ios siguientes: 


\subsubsection{Análisis Fundamental}

Consiste en la determinación tradicional de las razones o ratios de rentabilidad, liquidez, deuda, administración y el panorama de competencia para determinar factores que podrían impulsar o deteriorar la cotización de la empresa en el mercado. (Ver caso Lavaprontro, S.A.)

\subsubsection{Análisis Técnico}

Incluye lo anterior más la determinación de patrones de comportamiento del precio de las acciones para encontrar niveles históricos de negociación.

Este último es un tipo de análisis con fines netamente especulativos, pero que no deja de tener su importancia, pues le dirá al investigador cuales han sido los mejores momentos de la empresa.

En economías donde no existe un mercado de valores con una estructura y funcionabilidad adecuadas, este tipo de análisis puede tender a ofrecer datos poco fiables. En tal sentido, el investigador debe poner especial atención o apalancarse de otros instrumentos y métodos.

\subsection{Análisis de los libros y registros 10}

Al análisis de los registros contables se conoce como "auditoria". Los técnicos de auditoria se basan en tres palabras de acción:

\subsubsection{Análisis}

Durante el análisis, los libros contables y registros se desglosan en las partes que los componen.

\subsubsection{Escrutinio}

Es la búsqueda de pistas en anotaciones poco usuales hechas en documentos, la ausencia de un propósito de negocios en una transacción o la falta de documentación en una transacción.

\subsubsection{Comparación}

Es la evaluación y comparación de los documentos contables que son fuente de información, con indicadores independientes disponibles, procedentes de fuentes externas. 
En una investigación financiera el análisis de los Libros de Diario y de Mayor de un negocio y la comprensión de los procedimientos contables nos pueden ayudar a:

- Identificar el movimiento de dinero durante el proceso delictivo.

- Identificar las fuentes y/o aplicaciones de fondos efectuadas por un individuo o negocio por un período dado.

- Determinar los participantes en transacciones financieras específicas.

- Descubrir pistas adicionales para análisis posteriores.

\subsection{Métodos de rastreo de fondos ${ }^{11}$}

La cantidad de dinero resultante de actividades ilegales o fraude financiero puede rastrearse o establecerse por medio de los métodos siguientes:

\subsubsection{Directo}

También conocido como de asuntos específicos, se basa en las transacciones financieras específicas que realizan o paga el sujeto o empresa investigada.

\subsubsection{Indirecto}

Se basa en pruebas circunstanciales para establecer la fuente de procedencia del dinero y rastrearla hasta llegar a las actividades ilegales o al fraude financiero. Dentro de este método podrían incluirse los Métodos de Gastos, de Valor Neto, y el Depósito Bancario.

La clave para probar un delito financiero reside, usualmente, en la demostración de que el sospechoso ha dispuesto o ha recibido fondos ilegales. En tal sentido, veamos las fórmulas de los métodos siguientes:

\section{Análisis del Valor Neto:}

\begin{tabular}{cc} 
& Ingresos \\
& Egresos \\
\hline- & Valor Neto \\
\hline & Valor Neto del año anterior \\
\hline & Incremento del año \\
\hline & Gastos Conocidos \\
\hline & Total Incrementos Valor Neto \\
\hline & Fondos Procedentes de Fuentes Conocidas \\
\hline
\end{tabular}


Es decir, las alzas y bajas en el valor neto del negocio durante un período, dan como resultado la identificación de fondos desconocidos que pudieran ser recibidos ilegalmente.

\section{Método de Gastos}

Gastos Totales

Fuentes Conocidas de Fondos

Fondos Procedentes de Fuentes Desconocidas

Aquí se hace una comparación entre los gastos conocidos y las fuentes conocidas de fondos durante un período. Este análisis es concluyente en que cualquier gasto en exceso debe provenir de fondos desconocidos recibidos por el sospechoso.

\section{Método de Depósitos Bancarios:}

Total Depósitos a Todas las Cuentas

- $\quad$ Transferencias y Redepósitos

$+\quad$ Gastos de Caja (En Efectivo)

Total Recibido Procedente de Todas las Fuentes

Fondos Procedentes de Fuentes Conocidas

Fondos Procedentes de Fuentes Desconocidas

Aquí puede apreciarse como a través del análisis de los registros bancarios y las fuentes conocidas de fondos es posible determinar los posibles fondos de fuentes desconocidas.

\subsection{Información contable}

A menor control, mayor riesgo. De aquí la importancia de la contabilidad, especialmente del análisis de los Estados Financieros de las unidades económicas desde una óptica diferente a la comercial. Para ello se recomiendan los pasos siguientes:

- Analizar que la información financiera esté acorde al sector económico al cual pertenece el negocio.

- Evaluar la distribución de la información.

- Identificar las cuentas de mayor riesgo.

- Usar el flujo de efectivo para prevenir el lavado de dinero.

- Determinar indicadores para evaluar riesgos.

- Conocer, adicionalmente, casos y modalidades de lavado de dinero ya investigados.

Para la evaluación de la información financiera, de forma elemental, podrá interpretarse un balance teniendo en cuenta la distribución de la información para determinar su liquidez y su solvencia, lo cual refleja el sector 
económico al que pertenece y la lógica del comportamiento con respecto a las compañías de su sector. Por ejemplo:

$$
\frac{\text { Activos Corrientes }}{\text { Pasivos Corrientes }}=\text { Grado de liquidez }
$$

Esto respecto al Capital neto de trabajo. La rotación de los Activos corrientes facilita determinar su rápida conversión a Efectivo, tanto de sus inventarios o su cartera, como es el caso de empresas comerciales.

Para el sector industrial el análisis de la estructura de sus Activos Fijos y Pasivos a largo plazo permite observar la solvencia de la compañía. Este nos hará razonar lo lógico o ilógico que sería un volumen muy alto de efectivo, de inventario o un valor significativo de maquinarias, dadas las circunstancias actuales (Ciclo Económico) del sector industrial analizado.

Con lo anterior puede identificarse la lógica de un período y evaluar el comportamiento acorde al sector económico al que pertenece.

El análisis de flujo de caja es importante por lo que en sí representa: Ingresos y Egresos en detalle. El propósito de este tipo de análisis es identificar temporalmente la escasez o excesos de efectivo.

1. Primer paso: Determinar los recibos de efectivo durante cada intervalo de la investigación.

2. Segundo paso: Establecer los desembolsos de dinero.

Una vez que los ingresos y desembolsos han sido probados documentalmente, el investigador puede determinar los saldos de efectivo al final del período analizado. Es recomendable analizar que el saldo bancario superior al que figura en el mes anterior significa que existe efectivo en exceso, incremento patrimonial y debe establecerse por qué no se invirtió ese exceso para obtener su retorno.

El flujo de Activos corrientes que se manifiesta en un Estado Financiero dará la alerta a fin de considerar a una persona como sospechosa, lo que indica que deberá ser investigada. Esto es en esencia lo que se trata de demostrar en el caso Lavapronto, S.A. que, aunque no ofrece en si una certeza acabada de que la empresa analizada sea culpable del delito de lavado, no menos cierto que es resulta ser un complemento investigativo básico.

El proceso investigativo-financiero es diferente al investigativo de fuentes, formas o modos, de interrogación y seguimiento en campo. Uno va a las fuentes documentadas y analiza el proceso técnico de cómo llegan los fondos y cómo salen. El otro es técnicamente más difícil, pues basa y complementa el resto de la investigación. 
De aquí surgen, genéricamente, los títulos de Unidad de Inteligencia Financiera y de Investigación Financiera, que ya han sido definidos.

Un proceso investigativo de lavado de activos es usualmente largo, aún en países que cuentan con leyes, instrumentos técnicos, preparación y recursos para actuar.

Aún actuando las unidades mencionadas, a su máxima capacidad, necesitarían del apalancamiento de otros organismos, nacionales o extranjeros, los cuales con su cuota redondearían el caso.

\section{Las Razones financieras como instrumentos analíticos e investigativos ${ }^{12}$}

Caso Lavapronto, S.A.

LAVAPRONTO, S.A.

Estado Financiero al 31 de diciembre del 2002

Activos

\begin{tabular}{lc}
\hline $\begin{array}{l}\text { Circulantes } \\
\text { Caja }\end{array}$ & $250,000.00$ \\
\hline Bancos & $2,575,000.00$ \\
Cuentas por cobrar & $75,000.00$ \\
Inventarios & $1,000,000.00$ \\
\hline & $3,900,000.00$ \\
\hline Fijos & \\
Edificios & $500,000.00$ \\
Terrenos & $25,000.00$ \\
\hline Mobiliarios & $25,000.00$ \\
\hline & $550,000.00$ \\
\hline Total de Activos & $4,450,000.00$ \\
\hline Pasivos & \\
\hline Circulantes & \\
\hline Cuentas por pagar & $280,000.00$ \\
\hline Documentos por pagar & $170,000.00$ \\
\hline Capital & $450,000.00$ \\
\hline Pasivo + Capital & $4,000,000.00$ \\
\hline
\end{tabular}


Aquí puede notarse el excesivo volumen que presentan los Activos circulantes y el bajo nivel de los Pasivos circulantes, lo que indica que el flujo de efectivo podría ser elevado. Esto puede determinarse en el llamado flujo de caja o de efectivo.

\section{LAVAPRONTO, S.A.}

Estados de Resultados

(Ganancias y Pérdidas)

\begin{tabular}{lc}
\hline & RDS \\
\hline Ventas & $12,000,000.00$ \\
\hline Costo de Venta & $7,000,000.00$ \\
\hline \multicolumn{1}{|c|}{ Utilidad Bruta } & $5,000,000.00$ \\
\hline Gastos de Ventas y Administración & $1,500,000.00$ \\
\hline Utilidades de Operación & $3,500,000.00$ \\
\hline Gastos por Intereses & $180,000.00$ \\
\hline Utilidades antes de Impuestos & $3,320,000.00$ \\
\hline Impuestos & $170,000.00$ \\
\hline Utilidad Neta & $3,150,000.00$ \\
\hline
\end{tabular}

\section{Razones o Ratios Financieros}

Son la relación de una cifra con otra dentro o entre Estados Financieros de una empresa, que permiten ponderar y evaluar los resultados de las operaciones de la compañía. Se asumirá el Índice Industrial como el factor ideal o como la media usual en torno a la cual deben rondar los productos obtenidos de las razones financieras, indicando la calidad del desempeño financiero en unos casos y operativo en otros.

Las principales se encuentran clasificadas en las cuatro (4) siguientes:

\section{Razones de Rentabilidad}

$$
\begin{aligned}
& \frac{\text { Utilidad Neta }}{\text { Ventas }}=\text { Margen de Utilidad } \\
& \frac{3,150,000.00}{12,000,000.00}=0.26=26 \%
\end{aligned}
$$


Mide el porcentaje de las ventas que logran convertirse en utilidad disponible para los accionistas comunes.

Índice Industrial 6.5\%

b) Rendimiento sobre la Inversión

1. (b) 1. $\frac{\text { Utilidad Neta }}{\text { Total de Activos }}=\frac{3,150,000.00}{4,450,000.00}=0.70=70 \%$
1. (b) 2. $\frac{\text { Utilidad Neta }}{\text { Ventas }} \times \frac{\text { Ventas }}{\text { Activos Totales }}=$
$\frac{12,000,000.00}{4,150,000.00}=0.26 \times 2.69=69 \%$

Indica la efectividad de la administración y su forma de proyectar las utilidades. En ambos casos se obtiene el mismo producto porcentual.

Índice Promedio Industrial 10\%, el producto porcentual de 70\% es muy elevado debido a la alta rotación que manifiestan los activos corrientes.

1. (c) Rendimiento sobre el Capital Contable

$\frac{\text { Utilidad Neta }}{\text { Capital }}=\frac{3,150,000.00}{4,000,000.00}=078=78 \%$

Mide lo que esta realizando la compañía para obtener rendimiento sobre los fondos que los accionistas han confiado a la administración.

Índice Promedio Industrial 15\%, un 78\% es elevado. 


\section{Razones de Liquidez}

2. (a) Razón Circulante

$$
\frac{\text { Activos Circulantes }}{\text { Pasivos Circulantes }}
$$

Mide la capacidad e empresa de generar efectivo a partir de sus activos circulantes y así lograr cubrir sus compromisos. Mientras mayor sea el resultado de esta Razón, existe mayor posibilidad de que los Pasivos (deudas) sean pagados y si se torna exagerado como en el caso de la empresa " LAVAPRONTO, S.A.", entonces la indica como sospechosa de ser un instrumento para lavar dinero.

\section{Ejemplo:}

$$
\frac{3,900,000.00}{450,000.00}=8.66
$$

Es decir que "LAVAPRONTO, S.A.", cuenta con RD\$8.66 por cada peso adeudado. El Índice deber ser de 2.1

2. (b) Prueba de Liquidez o Acida

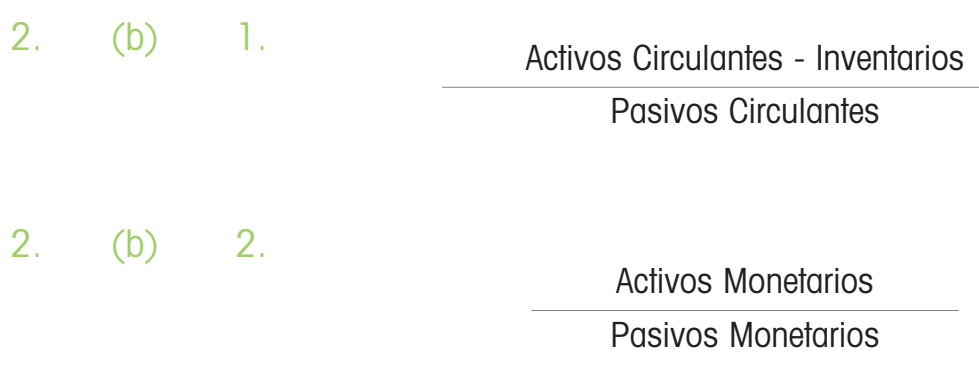

Aquí se incluyen las partidas cuya conversión en efectivo es inmediata, por lo que esta Razón expresará la disponibilidad inmediata de la empresa para cubrir sus deudas.

Ejemplo:

$$
\frac{3,900,000.00-1,000,000.00}{450,000.00}=6.44
$$

Lo que indica que LAVAPRONTO, S.A. dispone de RD\$6.44 por cada peso de deuda, de forma inmediata. El Índice Industrial es de RD\$1.00, lo que nos muestra un exceso de liquidez que, a su vez, llama la atención indicando que esta empresa puede estar siendo utilizada para lavar dinero. 


\section{3.) Razones de utilización de Activos}

3. (a) Rotación de Cuentas por Cobrar

$\frac{\text { Ventas }}{\text { Cuentas por cobrar }}=\frac{12,000,000.00}{75,000.00}=160$

Nos indica el número de veces que rotan las cuentas por cobrar, es decir, cuantas veces al año pagan las facturas los clientes. El Índice debe ser igual a 10 veces como mínimo, por lo que 160 veces nos indica una calidad de clientes sencillamente "excelente".

3. (b) Rotación de Inventarios

$$
\frac{\text { Ventas }}{\text { Inventarios }}=\frac{12,000,000.00}{1,000,000.00}=12
$$

Indica la rapidez con que estas entran y salen a la empresa, por lo que el resultado está expresado en cuantas veces la inversión de este tipo de activo es vendida. Si se compara la rotación obtenida 12 veces con el de la industria 7 veces notaremos que LAVAPRONTO, S.A., utiliza métodos muy eficientes de pedidos de inventarios.

3. (c) Rotación de Activos Fijos

$\frac{\text { Ventas }}{\text { Activos Fijos }}=\frac{12,000,000.00}{550,000.00}=12.8$

Los Activos Fijos son adquiridos conforme a la capacidad de la empresa en función de las ventas esperadas. El Índice Promedio Industrial es de 5.4, al compararlo con el 21.8 obtenido, nos indica que LAVAPRONTO, S.A. tiene un movimiento considerable de inventarios y cuentas por cobrar que afectan hiperpositivamente las ventas.

3. (d) Rotación de Activos Totales

$\frac{\text { Ventas }}{\text { Activos Totales }}=\frac{12,000,000.00}{4,450,000.00}=2.69$


Indica el número de veces que la empresa utiliza los activos para generar las ventas de los artículos que comercializa. El Índice Promedio es de 1.5, por lo que 2.69 es alta y excelente.

\section{4.) Utilización de Pasivos}

4. (a) Razón de Pasivos a Activos Totales

$\frac{\text { Pasivos Totales }}{\text { Activos Totales }}=\frac{450,000.00}{4,450,000.00}=0.10=10 \%$

Indica la proporción en que el total de recursos existentes en la empresa han sido financiados por instituciones o personas ajenas a LAVAPRONTO, S.A. El Índice Promedio es de $33 \%$ por lo que un $10 \%$ nos indica que la empresa o tiene un nivel de deuda apreciable. Es decir, el financiamiento de las operaciones con dinero ajeno es bajo.

El que los Pasivos sean notablemente reducidos no es un indicador por excelencia de que la empresa este lavando dinero. Debido a la cantidad de Activos que maneja a la rotación y rentabilidad no necesita del financiamiento de sus operaciones. La razón es que otras empresas, que podrían estar lavando dinero, pueden tener un exceso de pasivos caso contrario. Pero lo que no variará casi nunca será el flujo o movilidad de los activos corrientes, pues con estos irían resarciendo su alta deuda.

4. (b) Número de veces que se ganan intereses

Utilidad antes de

$\frac{\text { Impuestos e intereses }}{\text { Intereses }}=\frac{3,320,000.00}{180,000.00}=18.4$

El Índice Promedio Industrial es de 7. Mientras más elevada sea la razón, mayor será la capacidad que tenga la empresa para poder cubrir los Intereses que deba pagar. El 18.4 no indica que la empresa cuenta con más del doble del promedio Industrial.

En síntesis, se ha podido apreciar a una empresa que cuenta con un posicionamiento económico sólido, digno de ser paradigmático, pero en el entendido de que las Razones o Ratios Financieros no son indicadores completamente confiables, la investigación deberá profundizarse aún más. Es decir, se ha recibido la alerta, de 
una posibilidad llena de incertidumbres que deberemos limitar a la mínima expresión. Por ejemplo, deberá constatarse qué tipo de operación ha generado ese volumen de dinero. Una forma de empezar es haciendo las comparaciones de entradas y asientos en el Diario General, o Libro de Asientos de Operaciones con el Flujo de Caja o Cash Flow y el Inventario.

Todo lo anterior tiene la limitante de que las cifras contenidas en los Estados Financieros deben ser reales. Cualquier duda al respecto implicaría la ejecución de una Auditoria.

Cualquier tipo de información que se logre, producto del análisis aplicado, será complementario a las investigaciones que desarrollan los organismos investigativos y posteriormente los organismos judiciales.

Reitero que el método de las Razones o Ratios Financieros es de gran utilidad en cualquier proceso investigativo, pero aisladamente considerado, no ofrecerá respuestas suficientemente objetivas para emitir un juicio acabado de la empresa analizada.

Antes de finalizar debe indicarse la importancia de la evaluación de la información del Flujo de Caja o Cash Flow, indicando dos razones, que son las siguientes 13 :

(1) Analizar cuando las fuentes de fondos a corto plazo se negocian y obtienen por adelantado para ser utilizados por la empresa. En la medida en que estos montos fluctúan existe un momento en que la disponibilidad tiende a cero. Estas caídas deben ser anticipadas con el fin de no atentar con la seguridad de los fondos en el momento de una crisis.

(2) En períodos de inflación, el resultado de fluctuaciones, la disponibilidad de dinero debe ser más alta que las necesidades inmediatas. Este límite de efectivo debe ser invertido en instrumentos de mercado monetario a corto plazo tan pronto como el dinero esté disponible, con el fin de preservar su poder de compra y contribuir con la rentabilidad de los bienes y derechos existentes.

\section{Indicadores de Fraudes 14}

Alguna acción o indicador de la posible existencia de fraude, tal y como la omisión de algún ingreso específico, y registros inadecuados y grandes compras pagadas en efectivo podrían ser indicadores que denoten la ocurrencia de un fraude o de una actividad ilegal. El investigador financiero puede utilizar los siguientes indicadores de fraudes para ayudar a identificar a aquellos que están involucrados en actividades ilegales, identificando sus esquemas. 


\subsection{Cuarenta y seis (46) indicadores de fraudes}

A continuación citamos cuarenta y seis (46) posibles situaciones sospechosas. Es bueno señalar que las mismas no son rígidas o estáticas, sino más bien dinámicas y han de existir muchas otras.

1. Mantener dos juegos de libros y registros.

2. Ocultamiento de activos.

3. Destrucción de libros y registros.

4. Grandes o frecuentes transacciones en divisas cuyas compras se efectúen en efectivo.

5. Pagos a compañías o personas ficticias.

6. Asientos y documentos falsos o alterados.

7. Facturas o notas falsas.

8. Compras o ventas de activos subvaluados o sobrevaluados.

9. Uso de nombres falsos.

10. Grandes préstamos de la compañía a empleados u otras personas.

11. Cobros frecuentes de cheques recibidos.

12. Uso frecuente de cheques de caja.

13. Uso de fotocopias de facturas o recibos en lugar de los documentos originales.

14. Gastos personales pagados con fondos corporativos.

15. Cheques en los que se ha dejado en blanco el nombre del beneficiario y en los que después se ha Ilenado en fecha posterior.

16. Excesivos descuentos en facturación.

17. Excesivos defectos o material echado a perder.

18. Doble pago de facturas.

19. Uso innecesario de cuentas de cobro.

20. Individuos que negocian cheques que eran pagaderos a una empresa.

21. Endosos de segundas y terceras personas en cheques corporativos (de la compañía).

22. Uso excesivo de cheques de cambio o retiro de cuentas.

23. Préstamos de compañías localizadas en países que son refugio fiscal. 
24. Declaración de impuestos por cantidades menores a las reales, atribuibles a transacciones específicas y negociación por parte del causante de haber recibido el ingreso, o incapacidad para proporcionar una explicación satisfactoria de su omisión.

25. Incrementos substanciales no explicados en valor neto, especialmente sobre un período de años.

26. Depósitos bancarios de fuentes inexplicables que exceden en forma substancial el ingreso declarado.

27. Ocultamiento de cuentas bancarias, cuentas de corretaje y otras propiedades.

28. Explicación inadecuada de transacciones por grandes sumas de divisas, o el gasto inexplicables de divisas. (Especialmente cuando se trata de un negocio que no requiere grandes cantidades de efectivo).

29. Incumplimiento en el depósito de los recibos en la cuenta del negocio, contrario a las prácticas normales.

30. Incumplimiento con la declaración de impuestos, especialmente por un precio de varios años aunque se recibieran cantidades substanciales de ingreso gravable.

31. Reclamación de deducciones ficticias o inadecuadas.

32. Cantidades substanciales de gastos personales deducidos como gastos de negocios.

33. Asientos falsos o alteraciones hechas en los libros y registros, documentos fechados con fecha atrasada o post-fechados, facturas falsas o estados financieros falsos, u otros documentos falsos.

34. No llevar los libros adecuados, especialmente si ya se le dio aviso por parte del inspector como resultado de algún examen previo, ocultamento de registros o rehusarse a mostrar ciertos registros.

35. Distribución de ingresos a socios ficticios.

36. Inclusión de ingresos o deducciones en la declaración de un causante relacionado, cuando existe diferencia en las tasas de impuestos.

37. Declaraciones falsas, especialmente si se hicieron bajo juramento, respecto a un hecho material involucrado en la investigación.

38. Intentos de obstruir la investigación. Incumplimiento para responder a preguntas pertinentes o cancelación reiterada de citas concertadas. Evitar al investigador.

39. El conocimiento del causante respecto a impuestos y prácticas de negocios cuando aparecen diversos puntos cuestionables en las declaraciones.

40. Destrucción de libros y registros, especialmente si fueron confeccionados exactamente antes de la investigación. 


\footnotetext{
4. Transferencia de activos para fines de ocultamiento.

42. Involucramiento en actividad ilegal (ingreso ilegal).

43. Incumplimiento para revelar todos los hechos relevantes a la persona que prepara la declaración.

44. Incumplimiento para seguir las indicaciones y consejos del contador o abogado.

45. Riqueza inexplicable.

46. Asociación de negocios con empresas localizadas en países que son paraísos fiscales.
}

\subsection{Prácticas contables inadecuadas en el ciclo de tesorería 15}

En materia de fraude pueden presentarse situaciones y prácticas intencionales o errores por omisión. Se plantearán algunos casos en cuanto al uso del efectivo y de las inversiones.

En cuanto al efectivo:

- El hacer cortes incorrectos de ingresos y egresos de caja y bancos, aunque esto no implica necesaria y directamente una falsedad o fraude, se debe poner especial atención.

- Si no se cierran oportunamente los registros de ingresos, eso puede dar lugar a que se incluyan en las cuentas de caja y banco sumas que corresponden al período contable siguiente. Esto sobreestima el efecto del periodo contable realizado y puede alterar otras cuentas como las cuentas por cobrar.

El efecto contrario ocurre si los cortes de ingresos de efectivo se hacen con mucha anticipación.

- Si los registros de egresos están mas allá de la fecha de cierre del ejercicio contable, el efectivo y las cuentas por pagar pueden mostrar cifras inferiores a las reales, mostrándose un mejor índice de capital o liquidez.

- Es inadecuado no separar, ni especificar, los fondos que están restringidos, porque pueden estar comprometidos en usos o destinos especiales, - como, depósitos a término, fideicomisos -, o estar sujetos a gravámenes, embargos, o no estar disponibles para un desembolso en un momento determinado. Esto altera la liquidez de una empresa. Es necesario revelar este hecho y disponer físicamente de los documentos que lo muestran.

En cuanto a las inversiones:

- Si se tienen valores y títulos negociables deben estar ajustados sus costos en libros, porque de lo contrario se presentarán sus valores inflados y sobreestimados. Si hay una baja significativa en el mercado, si en ellos se presenta un alza y no se registra, no se expresaría en una forma inadecuada, salvo si se van a vender. 
- Es prudente indicar en el balance general el precio o cotización en el mercado de los títulos y su clasificación en activos corrientes o a largo plazo, pues en caso contrario afectaría la liquidez, lo cual es incorrecto. Debe anotarse, también, el costo más los incrementos posteriores, en caso de que no estén ajustados en libros. Una forma de lavar dinero consiste en inflar el valor de las inversiones, produciendo incrementos ficticios que justifican niveles elevado de patrimonio.

\section{Control interno16}

Existe solo un sistema de control interno, el administrativo, que es el plan de organización que adopta cada empresa con sus correspondientes procedimientos y métodos, operaciones contables para ayudar, mediante el establecimiento de un medio adecuado, a lograr los objetivos siguientes:

- Mantener información fresca de la situación de la empresa.

- Coordinar sus funciones.

- Mantener una ejecutoria eficiente.

- Determinar si la empresa está operando conforme a las políticas establecidas que incluyen normas y procedimientos ortodoxos.

- Asegurarse que se están logrando los objetivos establecidos dentro de un riesgo moderado.

\section{1. El Modelo COSO, para la prevención}

El Committee of Sponsoring Organizations of the Treadway Comission COSO, desde mediados de los 80's vislumbraba la necesidad de evaluar las técnicas de control utilizadas hasta ese momento. De aquí nace este modelo de control interno para llenar la insatisfacción a todo lo relacionado con las regulaciones.

En la actualidad en nuevo enfoque de supervisión bancaria se hace basada en el modelo coso.

\section{Cuestionario coso}

A continuación, se ofrece un cuestionario, aplicable a cualquier tipo de empresa, a través del cual podría implantarse el modelo de control interno COSO. A saber:

- ¿Cómo establecen y mantienen los directores y gerentes un fuerte ambiente y cultura organizacional apegados a la ética?

- ¿El ambiente de control establece el propósito de la organización y constituye la base para un sistema de 
control interno eficiente?

- ¿Los directores y gerentes dan el ejemplo de integridad y ética que exige la organización?

- ¿Se ha redactado un código de conducta para empleados? ¿Es reforzado mediante la capacitación, la comunicación integral y la solicitud a los empleados jerarquizados para que realicen declaraciones periódicas por escrito acerca de su cumplimiento?

- ¿Son razonables y realistas los objetivos de rendimiento y los incentivos de compensación o se crea una presión excesiva sobre el cumplimiento de resultados a corto plazo?

- ¿Está claro que cualquier informe financiero fraudulento no será aceptado?

- ¿Se ha interrelacionado la ética con los criterios que se utilizan para evaluar el rendimiento de las funciones de negocios?

- ¿Reacciona la dirección en forma correcta cuando recibe malas noticias de sus subordinados y/o de las funciones de negocios?

- ¿Existe un proceso ético que resuelva las demandas éticas privadas?

- ¿Se identifican los riesgos del negocio y se discuten abiertamente con el directorio?

- ¿Cómo identifica y maneja los riesgos la organización?

- ¿El sistema de control interno permite que la agencia valore, monitoree y maneje los riesgos más importantes?

- ¿Se identifica, recopila y comunica oportunamente la información interna y externa importante para fines de tomar decisiones y actuar?

- ¿Se identifican y analizan los riesgos y se toman acciones de forma rápida, a fin de mitigarlos?

- ¿Existen controles que aseguren que las decisiones de la dirección se llevan a cabo correctamente?

- ¿Como evalúa la organización su sistema de control interno para asegurarse de que es efectivo?

- ¿Los controles internos deben ser monitoreados por la gerencia departamental en forma progresiva y deben estar sujetos a una evaluación periódica?

- ¿Demuestran la dirección y la gerencia que aceptan la responsabilidad de controlar en lugar de delegar todo lo concerniente al personal de finanzas y de auditoria?

- ¿Monitorea la gerencia en forma rutinaria los controles en el momento en que se desarrollaron las operaciones de la organización?

- ¿Asigna la gerencia claras responsabilidades en cuanto a la capacitaron y al monitoreo de los controles internos? 
- ¿Se llevan a cabo y se documentan las evaluaciones periódicas y sistemáticas de los sistemas de control?

- ¿Dichas evaluaciones son efectuadas por el personal que tiene la responsabilidad, experiencia del negocio y conocimientos adecuados sobre los temas de la organización?

- ¿Cuáles criterios se utilizan para evaluar los controles?

- ¿Las fallas en los controles se informan a la gerencia general y se corrigen oportunamente?

- ¿Se incorporan los controles adecuados, a medida que se diseñan y se aplican nuevos sistemas?

- ¿Cómo usted puede determinar que el comité de auditoria del directorio es efectivo?

- ¿Un comité de auditoria esclarecedor y proactivo es un factor poderoso para la autorregulación de la organización?

- ¿El directorio ha revisado recientemente la suficiencia de la carta constitutiva del comité de auditoria?

- ¿Los miembros del comité de auditoria están trabajando y actúan en forma independiente de la dirección?

- ¿El comité de auditoria comprende y monitorea el ambiente de control de la organización, en su totalidad?

- ¿El comité de auditoria supervisa la oportunidad, importancia y confiabilidad de la información operativa y financiera suministrada al directorio, a inversionistas, demás accionistas y terceros?

- ¿Supervisa el comité de auditoria la existencia y el cumplimiento del estándar ético que se ha planteado la organización?

- ¿El comité de auditoria o la dirección en su totalidad tiene una relación significativa y a la vez desafiante con los auditores externos independientes, los auditores internos, los funcionarios de control financiero, los funcionarios del área de negocios?

- ¿Cómo sabe que la función de auditoria interna es efectiva? ¿Utiliza indicadores específicos para medir su gestión?

- ¿Una auditoria interna organizada y que funcione eficientemente proporciona a la dirección y al comité de auditoria un instrumento que les ayudara a monitorear la confiabilidad e integridad de la información financiera y operativa?

- ¿La función de auditoria interna cuenta con el apoyo total de la gerencia general, el comité de auditoria y de Ios directores? ¿Está correctamente posicionada en el organigrama?

- ¿El comité de auditoria ha controlado que el alcance de las responsabilidades de la auditoria interna sea el adecuado?

- ¿Es correcta la relación a nivel de organización entre auditoria interna y los ejecutivos de alto nivel?

- ¿Auditoria interna posee y emplea líneas abiertas de comunicación y de acceso privado a todos los 
funcionarios de alto nivel y al comité de auditoria?

- ¿Los informes de auditoria cubren los temas correctos, se distribuyen a la gente adecuada y se cumplen de forma oportuna?

- ¿Los integrantes del departamento de auditoria, de mayor jerarquía, tienen el nivel de experiencia adecuado?

- ¿Cómo puede estar seguro de que los controles internos de la organización están realmente funcionando?

Los controles internos no aseguran el éxito a una organización, pues las malas decisiones, los gerentes incapaces, las conductas inmorales, la confabulación, las infracciones a los mismos controles y la presión de la competencia pueden generar problemas. No obstante, los controles eficaces ayudan a que las organizaciones alcancen sus objetivos, minimicen las incertidumbres y la ocurrencia de sorpresas desagradables.

El control interno es realizado por personas, y no es solamente un manual de políticas y formularios sino que hay personas que actúan en cada uno de los niveles de la organización. Se supone que el control interno proporciona una seguridad razonable, más no absoluta, a la gerencia general de la entidad. El control interno se ajustar al logro de los objetivos de la empresa en una o mas categorías, que están separadas pero superpuestas por ser parte de una misma estructura.

Al revisar, en su totalidad, la eficacia de los cinco (05) componentes de control cOSO en su organización, podrá tener la certeza de que las futuras condiciones a las que se han hecho referencia podrán ser prevenidas, detectadas y corregidas en el curso de las operaciones normales de su empresa.

\subsubsection{Diferencias entre el modelo tradicional y el modelo COSO17}

\begin{tabular}{|c|c|}
\hline Tradicional: & coso: \\
\hline Mecanismos & Mecanismos \\
\hline $\begin{array}{l}\text { - Registro } \\
\text { - Segregación de Funciones } \\
\text { - Niveles de Autorización } \\
\text { - Cumplimiento de Normas y Políticas Impuesta } \\
\text { - Custodia y Archivo }\end{array}$ & $\begin{array}{l}\text { - Orientado a garantizar la confiabilidad de la } \\
\text { información respecto a la realidad económica } \\
\text { - Autocontrol mediante indicadores de gestión } \\
\text { - Cumplimiento de normas y políticas concertadas } \\
\text { y funcionales } \\
\text { - Archivo electrónico protegido }\end{array}$ \\
\hline Oportunidad & Oportunidad \\
\hline $\begin{array}{l}\text { - Correctivo-Reactivo } \\
\text { - Detectivo }\end{array}$ & $\begin{array}{l}\text { - Preventivo-Proactivo } \\
\text { - Automático }\end{array}$ \\
\hline
\end{tabular}




\section{La administración del riesgo 18}

Toda empresa debe tipificar sus riesgos, pues un riesgo no tipificado ni medido es un problema de Control Interno. Riesgo es la incertidumbre de concurrencia de una pérdida humana, moral o económica, que deben ser identificadas y clasificadas. Estas incertidumbres podrían llevarse a su mínima expresión, pero nunca podrán ser completamente eliminadas.

En la actualidad uno de los mayores riesgos a los que se exponen los sistemas financieros y cambiarios de todo el mundo es ser utilizados para lavar dinero o activos. Es, en síntesis, un riesgo inherente del que no están exentas las empresas de otra naturaleza. La experiencia de casos nos muestra que mientras más grande es la empresa, mayor es el nivel de riesgo que afronta.

El profesor Miguel A. Cano, en su libro Modalidades del Lavado de Activos, ha identificado cinco (5) variables a tomar en cuenta para prevenir el lavado de activos. El las Ilama "Las 5C del Control para Prevenir el Lavado de Activos." A saber:

- Concienciación y sensibilización.

- Conocimiento integral del delito.

- Conocimiento interno y del entorno de la institución.

- Conocimiento integral del cliente.

- Conocimiento de modalidades e identificación de controles y sanciones.

El seguimiento de estas 5C nos garantizará una Administración Efectiva del Riesgo.

\section{Implicaciones económicas y sociales del lavado de activos ${ }^{19}$}

\subsection{Implicaciones Económicas}

El lavador de dinero no coloca los recursos sucios en base a tasas de retorno esperados, sino en base a la facilidad de eludir controles. Es por lo que el dinero sucio tiene a ir a países con menos controles restrictivos.

La globalización de la economía mundial ha permitido el movimiento libre y rápido de importantes sumas de dinero a través de las fronteras en busca del ámbito económico más conveniente y de la tasa de retorno más alta.

La globalización de los Mercados de Capitales tiene sus consecuencias positivas, tales como las siguientes: 
(a) Permite que el capital salga de los países donde su productividad es lenta y vaya a los países donde su productividad es alta, procurando, así, una mejor distribución de las reservas mundiales y consecuentemente una mayor tasa de crecimiento de la economía mundial.

(b) Facilita la superación de crisis, producto de la deuda, dado el fácil acceso al mercado internacional de capitales a países dispuestos a seguir las políticas necesarias de ajustes económicos.

(c) Ayuda en la enorme tarea de integración de las economías en transición al sistema económico internacional.

(d) Facilita el reciclaje de capital de países con superávit en las cuentas corrientes, a aquellos con déficit.

Si bien los beneficios potenciales de una integración económica y una libertad de movimientos de capitales mayores son obvios y significativos, inevitablemente esto tiene sus costos. Por ejemplo, ante la mayor libertad y amplitud en el movimiento de los bienes y ante el mayor volumen de intercambio comercial, se ha hecho más fácil para los narcotraficantes y traficantes de armas trasladar sus mercancías de un país a otro.

En cuanto el Mercado de Capitales, uno de esos costos es el movimiento de capitales ocasionalmente amplio, repentino y promovido por los especuladores que buscan ganancias rápidas, o por inversionistas legítimos que pueden verse incluidos por un instinto gregario a retirar su dinero del país donde lo habían invertido. El desarrollo de las sociedades de inversión y la creciente importancia de los derivados financieros (swaps, futuros, opciones, etc.) pueden haber contribuido a estos movimientos de capitales repentinos, susceptibles de crear dificultades para los países implicados.

Podríamos señalar otro costo potencial de la globalización y es que ésta permite que los países con déficit fiscales estructurales, es decir, con déficit no generados por el ciclo económico, posterguen la realización de las correcciones necesarias en sus cuentas fiscales en virtud de un fácil acceso al préstamo extranjero. Estos países pueden, de ese modo, tender a acumular más deuda de lo prudente.

Todo se traduce en una mayor facilidad que la integración de los mercados de capitales, proporciona a elementos delictivos para lavar internacionalmente el dinero adquirido de sus actividades ilegales.

Los costos a la economía mundial producto del lavado de dinero pueden ser, entre otros, los siguientes:

- Perjudicar las operaciones efectivas de las economías nacionales y promover políticas económicas más pobres. Especialmente, en los países en vías de desarrollo.

- Corromper lentamente el mercado financiero y reducir la confianza del público en el sistema financiero, con lo que aumentaría el riesgo y la inestabilidad. 
- Reducir la tasa de crecimiento de la economía mundial, como consecuencia de lo anterior.

En razón del volumen de dinero que debe lavarse, a la concentración de este en pocos países y debido a que muchos países han adoptado políticas de prevención y detención que ponen en riesgo a estos delincuentes, se han observado intentos cada vez mas sofisticados tendientes a lavar intencionalmente estos bienes.

Hechos tales como:

- La privatización de empresas públicas a gran escala en muchos países.

- El crecimiento de los mercados bursátiles en países en vía de desarrollo.

- La creciente diversificación de instrumentos financieros en el mercado financiero internacional.

- La creciente participación de capital internacional controlado a través de entidades que aclaran tener su domicilio legal en países considerados paraísos fiscales.

- La falta de una efectiva regulación en muchos países y específicamente en economías en vías de desarrollo o en transición.

- La gran cantidad de capital extranjero absorbido por economías en transición y en muchos países en desarrollo, ha creado por un lado una fuerte demanda de capital financiero y por otro las condiciones que facilitan las inversiones anónimas de este capital.

- La crisis económica mundial producto del estancamiento de la producción.

La globalización de los mercados y la creciente sofisticación técnica han allanado el proceso. Es muy difícil distinguir entre movimientos de capitales alentados o inducidos por la diferencias en las políticas económicas y movimientos de capitales que reflejan intentos de lavado de dinero. Las estadísticas disponibles no permiten hacer esta distinción.

Una operación que podría generar sospechas es la del dinero que se desplaza de países con buenas políticas y tasas altas a países con ventajas inferiores, dando así la impresión de desafiar las leyes de la economía. Es como si $2+2=3$.

Como consecuencia de esos movimientos de capitales contrarios al análisis objetivo de la realidad económica, los formuladores de políticas económicas pueden decidir ejecutar una opción errada. Por ejemplo, si éstos frente a una inflación elevada, un tipo de cambio sobrevaluado y un gran déficit fiscal, ven ingresar capitales, probablemente sostendrían un esquema de política económica expansiva, que es en términos políticos ideal. Pero la realidad es otra, pues la economía estaría sobre cimientos muy volátiles, aunque genera una ilusión de solidez que predispone al cambio a una política más conservadora. 
En cuanto a la distribución óptima 0, al menos, eficiente de los recursos, una gran reserva de capitales lavados puede producir cierta inestabilidad intrínseca en la economía mundial. La transferencia de un monto importante de un país a otro podría tener consecuencias económicas significativas, creando dificultades macroeconómicas para los países que reciben o que pierden este dinero, pues grandes egresos o ingresos de capitales podrían influir en variables como el tipo de cambio, las tasas de interés e inclusive en los precios de determinados bienes de inversión, tales como casas y terrenos.

\subsection{Implicaciones Sociales}

La apariencia lícita de los fondos que opera el lavador puede llevar a empresarios probos a negociar con él, lo que relacionaría de forma indirecta a personas ajenas al crimen con el mismo. Una vez el lavador logra colocar capitales sucios, genera relaciones de negocios conexas que infectarán a capitales bien habidos.

La operatividad de esquemas de lavado, sin su consecuente castigo, generaría males que afectarían sensiblemente los cimientos de la sociedad en general, pues atentaría contra la gobernabilidad. Fruto del lavado, las sociedades estarían a expensas de las situaciones negativas siguientes:

- Impunidad

- Falsos valores

- Competencia desleal

- Generación de riqueza ficticia

- Fraudes y engaños

El carácter ilegal de sus operaciones hace que los lavadores tiendan a enfocar su conducta hacia lo que les ofrezca el menor peso regulatorio posible, sistemas investigativos y judiciales débiles y, por lo tanto, fáciles de corromper, así como hacia estructuras mal concebidas.

En síntesis, toda acción lesiva a la economía es perjudicial a la sociedad. En tal sentido, con la previa explicación de las implicaciones económicas, se entiende que lo dañino del lavado ha sido por demás enfocado. 


\section{Bibliografía recomendada}

Cano C., Miguel Antonio. Modalidades de Lavado de Dinero y Activos", Ecoe Ediciones, Bogotá, Colombia, 2001.

Cardenas, Mauricio Y Steiner, Roberto (Copiladores). Corrupción, Crimen y Justicia. Una Perspectiva Económica, Trabajos Presentados en la Región Anual de la Asociación Latinoamericana y del Caribe de Economía (LACEA), Tercer Mundo, S.A., Bogotá, Colombia, 1998.

Castro M., Heiromy. "Introducción a la Problemática del Lavado de Dinero". Conferencia, Superintendencia de Bancos, Santo Domingo, R.D., 1998.

"Técnicas Financieras para la Investigación del Lavado de Dinero (Lavapronto, S.A.). Conferencia, Programa de las Naciones Unidas para la Fiscalización Internacional de las Drogas (PNUFID), Santo Domingo, R.D., 2000.

"La Investigación Financiera en Casos de Lavad de Activos. (Administración del Riesgo)". Curso, Fundación Institucionalidad y Justicia, Inc., Santo Domingo, R.D., 2001.

"Normas y Políticas Implantadas por la Autoridad Competente para la Prevención del Lavado de Activos". Conferencia, Fundación Institucionalidad y Justicia, Inc., Santo Domingo, R.D., 2002.

. "Conociendo la Banca Off-Shore". Conferencia, Superintendencia de Bancos, Santo

Domingo, R.D., 2003

"Crímenes Financieros: Corrupción, Financiamiento del Terrorismo y Lavado de Activos. Conferencia presentada en el marco de la III Seminario, Estado, Gestión y Control, Santo Domingo, R.D., 2003.

"Financiamiento del Terrorismo". Conferencia, VII Feria Internacional del Libro, Santo Domingo, R.D., 2004.

Del Rosario Zorrilla, Héctor. "Análisis de Costo y Técnicas de Fijación de Precios", Editora Búho, Santo Domingo, R.D., 2001.

Estupiñán Gaitan, Rodrigo. Estado de Flujo de Efectivo y de Cambios en la Situación Financiera, Editora Roesga, Bogotá, Colombia, 2001 
Guajardo, Gerardo. Contabilidad Financiera, McGraw-Hill, México, 1994.

Jorge, Antonio Y Salazar-Carrillo, Jorge. Price Policies and Economic Growth, Praeger Publishers, Westport, CT, EUA, 1997.

Schott, Paul Allan. Reference Guide to Anti-Money Laundering and Combating the Financing of Terrorism, Banco Mundial-Fondo Monetario Internacional, Washington, D.C., EUA, 2003.

Vidales Rodríguez, Caty. El Delito de Legitimación de Capitales: Su Tratamiento en el Marco Normativo Internacional y en la Legislación Comparada", Centro para la Administración de Justicia, Florida Internacional University, Miami, FL., EUA, 1998.

Financial Intelligence Units, An Overview, Fondo Monetario Internacional-Banco Mundial, Washington, D.C., EUA, 2004.

Transparencia \& Corrupción: Conclusiones de los Seminarios Sectoriales, Fundación Institucionalidad y Justicia, Inc.-Banco Mundial, Santo Domingo, R.D., 2002.

Prevencao e Combate á Lavagem de Dinheiro, Consejo de Control de Actividades Financieras, Brasilia, D.F., Brasil, 2001.

Financial Investigation Terminology, a Multilingual Glossary, Financial Crimes Enforcement Network, The Department of the Treasury, Washington, D.C., EUA., 1992.

Cyberpayments and Money Laundering: Problems and Promise, RAND Published, Santa Monica, CA, EUA, 1998.

Curso de Investigación Financiera para Unidades de Inteligencia Financiera, Internal Revenue Service (IRS), The Department of the Treasury, EUA, El Salvador, San Salvador, 1997. 


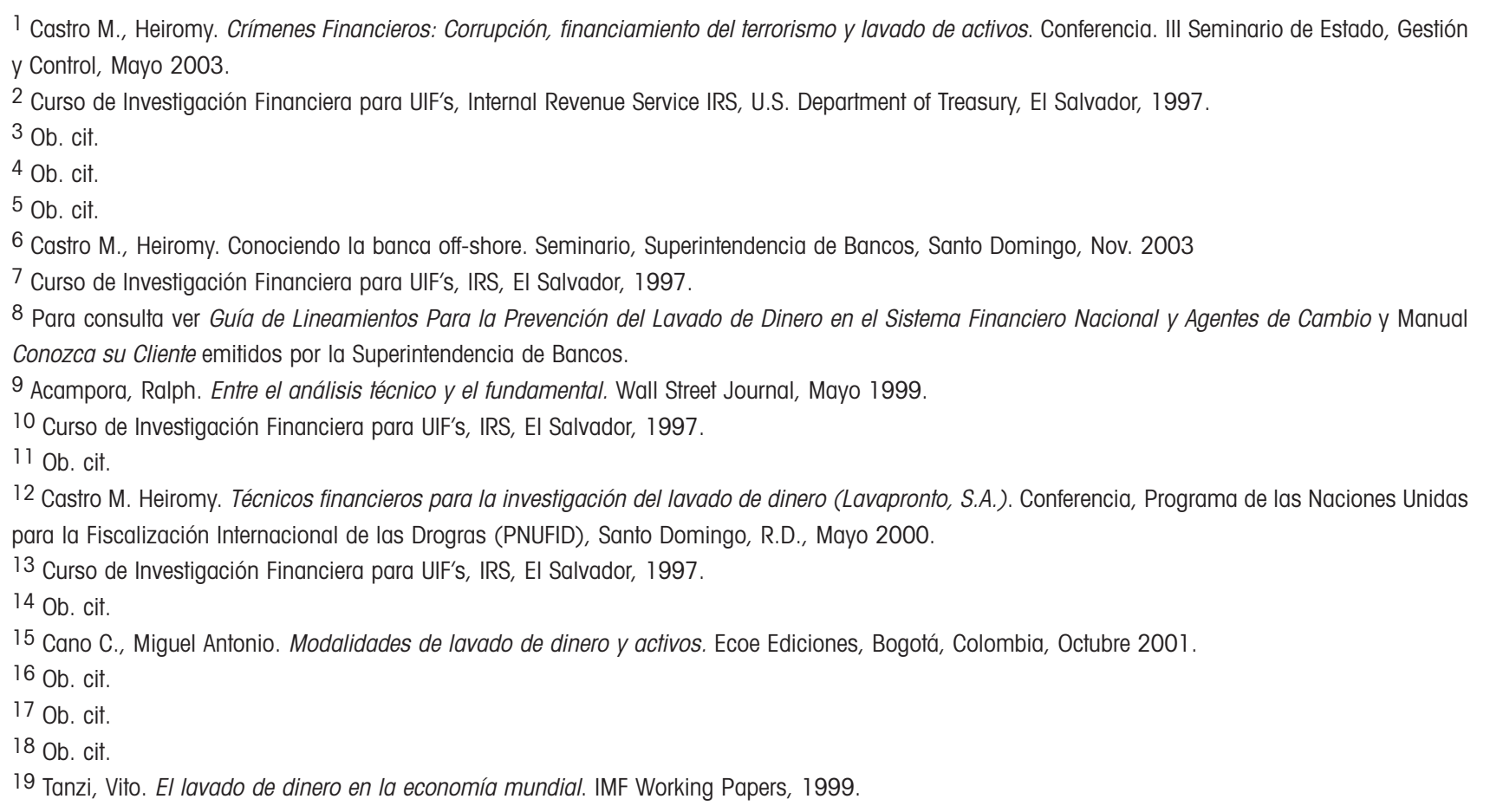


Justicia y

Gobernabilidad

$\overline{\text { Fortaleciendo el estado de derecho }}$

ESCUELA NACIONAL

DE LA JUDICATURA

República Dominicana 